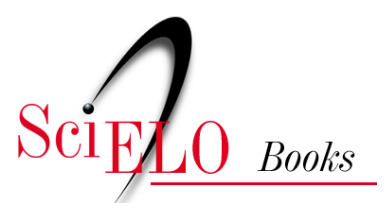

\title{
Processos de alcoolização Indígena no Brasil perspectivas plurais
}

\author{
Maximiliano Loiola Ponte de Souza (org.)
}

SOUZA, M.L.P., comp. Processos de alcoolização Indígena no Brasil: perspectivas plurais [online]. Rio de Janeiro: Editora FIOCRUZ, 2013, 249 p. Saúde dos povos Indígenas collection. ISBN: 978-85-7541581-8. https://doi.org/10.7476/9788575415818.

\section{International license.}

Todo o conteúdo deste trabalho, exceto quando houver ressalva, é publicado sob a licença Creative Commons Atribição 4.0. 
Processos de Alcoolização Indígena no Brasil: perspectivas plurais 


\section{FUNDAÇÃO OSWALDO CRUZ \\ Presidente \\ Paulo Gadelha \\ Vice-Presidente de Ensino, Informação e Comunicação Nísia Trindade Lima}

\section{EDITORA FIOCRUZ}

Diretora

Nísia Trindade Lima

Editor Executivo

João Carlos Canossa Mendes

\section{Editores Científicos}

Gilberto Hochman e Ricardo Ventura Santos

Conselho Editorial

Ana Lúcia Teles Rabello

Armando de Oliveira Schubach

Carlos E. A. Coimbra Jr.

Gerson Oliveira Penna

Joseli Lannes Vieira

Ligia Vieira da Silva

Maria Cecília de Souza Minayo

Coleção SaÚde dos Povos Indígenas

Editores Responsáveis: Ricardo Ventura Santos

Carlos E. A. Coimbra Jr. 
Processos de Alcoolização Indígena no Brasil: perspectivas plurais

Maximiliano Loiola Ponte de Souza organizador 
Copyright (c) 2013 do organizador

Todos os direitos desta edição reservados à

FUNDAÇÃO OSWALDO CRUZ / EDITORA FIOCRUZ E ASSOCIAÇÃO BRASILEIRA DE ESTUDOS POPULACIONAIS (ABEP)

Capa

Danowski Design

Criada a partir de ilustração de mixígu, um tipo de cesta feita pelos Bororo.

Fonte: Os Bororos Orientais: orarimogodogue do Planalto Oriental de Mato Grosso, de Antonio Colbacchini

e Cesar Albisetti. São Paulo: Companhia Editora Nacional, 1942. p. 147.

Projeto gráfico e editoração eletrônica

Angélica Mello e Daniel Pose Vazquez

Revisão e copidesque

Augusta Avalle e M. Cecilia G. B. Moreira

Catalogação na fonte

Instituto de Comunicação e Informação Científica e Tecnológica em Saúde/Fiocruz Biblioteca de Saúde Pública

S729 Souza, Maximiliano Loiola Ponte de (Org.).

Processos de Alcoolização Indígena no Brasil: perspectivas plurais. / organizado por Maximiliano Loiola Ponte de Souza. - Rio de Janeiro: Editora FIOCRUZ, 2013.

252 p. : il. (Coleção Saúde dos Povos Indígenas)

ISBN: 978-85-7541-426-2

1. Alcoolismo - prevenção G controle. 2. Saúde de Populações Indígenas.

3. Índios Sul-Americanos.4. Consumo de Bebidas Alcoólicas - epidemiologia.

5.Brasil - epidemiologia. I. Título.

CDD - 22.ed. - 362.292

2013

EDITORA FIOCRUZ

Av. Brasil, 4036 - 1ํandar - sala 112 - Manguinhos

21040-361 - Rio de Janeiro - RJ

Tels.: (21) 3882-9039 e 3882-9007/ Telefax: (21) 3882-9006

e-mail: editora@fiocruz.br

http://www.fiocruz.br/editora

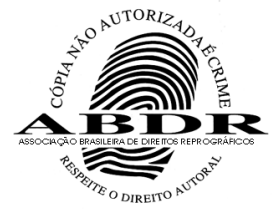


Autores

Andrey Moreira Cardoso é médico, doutor em saúde pública pela Escola Nacional de Saúde Pública Sergio Arouca da Fundação Oswaldo Cruz (Ensp/Fiocruz). É pesquisador assistente do Departamento de Endemias Samuel Pessoa da Ensp/ Fiocruz.

Ari Ghiggi Junior é antropólogo, mestre em antropologia social pela Universidade Federal de Santa Catarina e doutorando da mesma instituição.

Esther Jean Langdon é antropóloga, mestre em antropologia pela University of Washington e doutora em antropologia pela Tulane University of Louisiana. É professora titular da Universidade Federal de Santa Catarina e coordenadora do Instituto Nacional de Pesquisa Brasil Plural.

João Azevedo Fernandes é historiador, mestre em antropologia cultural pela Universidade Federal de Pernambuco e doutor em história moderna pela Universidade Federal Fluminense. É professor adjunto do Departamento de História da Universidade Federal da Paraíba.

João Luiz Pena tem graduação em engenharia civil e em ciências sociais; é mestre em saneamento, meio ambiente e recursos hídricos pela Universidade Federal de Minas Gerais (UFMG). É pesquisador do Departamento de Engenharia Sanitária e Ambiental da Escola de Engenharia da UFMG e pesquisador associado do Núcleo de Pesquisa em Epidemiologia da Universidade Federal de Ouro Preto.

Justino Sarmento Resende, Pe, indígena da etnia Tuyuka, do distrito de Pari-Cachoeira, município de São Gabriel da Cachoeira/AM, tem graduação em teologia e é mestre em educação pela Universidade Católica Dom Bosco, Campo Grande/MS. É sacerdote da Sociedade de São Francisco de Sales (Salesianos). 
Laércio Fidelis Dias é cientista social e doutor em antropologia social pela Universidade de São Paulo. É professor do Departamento de Sociologia e Antropologia da Universidade Estadual Paulista "Júlio de Mesquita Filho" (Marília/SP).

Luciane Ouriques Ferreira é cientista social, doutora em antropologia social pela Universidade Federal de Santa Catarina e pós-doutoranda do Programa de Epidemiologia em Saúde Pública da Escola Nacional de Saúde Pública Sergio Arouca da Fundação Oswaldo Cruz.

Luiza Garnelo é médica sanitarista e antropóloga, mestre em ciências sociais pela Pontifícia Universidade Católica de São Paulo e doutora em antropologia pela Universidade Estadual de Campinas. É pesquisadora do Instituto Leônidas e Maria Deane da Fundação Oswaldo Cruz (ILMD/Fiocruz).

Manuel Ignacio Quiles é psicólogo e mestre em saúde e sociedade pela Universidade Federal do Mato Grosso. Atua como psicólogo clínico de orientação transpessoal em Mendoza (Argentina).

Maria de Betania Garcia Chaves é psicóloga e mestre em saúde pública pela Escola Nacional de Saúde Pública Sergio Arouca da Fundação Oswaldo Cruz. É coordenadora de tratamento do Conselho Municipal de Políticas Públicas sobre Álcool e Outras Drogas de Angra dos Reis e técnica da Unidade Municipal de Saúde Aldeia Indígena na Fundação de Saúde de Angra dos Reis.

Maximiliano Loiola Ponte de Souza é médico psiquiatra e sanitarista, mestre em sociedade e cultura na Amazônia pela Universidade Federal do Amazonas e doutor em ciências pelo Instituto Fernandes Figueiras da Fundação Oswaldo Cruz (Fiocruz). É pesquisador do Instituto Leônidas e Maria Deane (IMDL) da Fiocruz.

Moab Duarte Acioli é médico psiquiatra, mestre em antropologia cultural pela Universidade Federal de Pernambuco e doutor em saúde pública pela Universidade Estadual de Campinas. É professor adjunto da Universidade Católica de Pernambuco.

Salette Maria Barros Ferreira é psicóloga, psicanalista e doutora em saúde mental pela Universidade Federal do Rio de Janeiro (UFRJ). É coordenadora adjunta do Programa de Estudos e Assistência ao Uso Indevido de Drogas do Instituto de Psiquiatria (Projad/Ipub) da UFRJ e professora visitante do Laboratório de Educação, Trabalho e Assistência em Saúde (Letras) do Ipub/UFRJ. 
Suely Ferreira Deslandes é socióloga, mestre em saúde pública pela Fundação Oswaldo Cruz (Fiocruz) e doutora em ciências pela mesma instituição. É pesquisadora titular da Fiocruz, professora do mestrado e doutorado em saúde da criança e da mulher do Instituto Fernandes Figueiras e do mestrado e doutorado em saúde pública da Escola Nacional de Saúde Pública Sergio Arouca (Ensp) da Fiocruz. 
Sumário

Prefácio

Apresentação

1. O Abuso de Álcool entre os Povos Indígenas no Brasil: uma avaliação comparativa

Esther Jean Langdon

2. Cauinagens e Bebedeiras: os índios e o álcool na história do Brasil 47 João Azevedo Fernandes

3. 'Mansidão de fogo': aspectos etnopsicológicos do comportamento alcoólico entre os Bororo 65 Manuel Ignacio Quiles

4. Quando, como e o que se Bebe: o processo de alcoolização entre povos indígenas do Alto Rio Negro, Brasil

Maximiliano Loiola Ponte de Souza e Luiza Garnelo

5. Modos de Vida e Modos de Beber de Jovens Indígenas em um

Contexto de Transformações 95

Maximiliano Loiola Ponte de Souza, Suely Ferreira Deslandes e Luiza Garnelo

6. Consumo de Bebidas Alcoólicas entre os Povos Indígenas do Uaçá 107 Laércio Fidelis Dias 
7. Tomar uma Fuga: metáforas sobre o contexto social e econômico da alcoolização pankararu

Moab Duarte Acioli

8. Os Índios Maxakali: a propósito do consumo de bebidas de alto teor alcoólico

João Luiz Pena

9. Controle Social como Autoatenção: estratégias kaingang diante do abuso de bebidas alcoólicas

Ari Ghiggi Junior e Esther Jean Langdon

10. Da Prevenção de Doenças à Promoção da Saúde: reflexões a partir da questão do uso de bebidas alcoólicas por indígenas

Maximiliano Loiola Ponte de Souza

11. As Boas Palavras Mbyá-Guarani como Caminho para a Redução do Uso de Bebidas Alcoólicas

Luciane Ouriques Ferreira

12. Problemas Relacionados ao Uso de Álcool entre Indígenas Guarani no Estado do Rio de Janeiro: uma experiência de abordagem terapêutica integrada

Maria de Betania Garcia Chaves, Andrey Moreira Cardoso e

Salette Maria Barros Ferreira

13. Educação Escolar Indígena e a Bebida Alcoólica: reflexões sobre o contexto do Triângulo Tukano, Alto Rio Negro

Justino Sarmento Rezende 


\section{Prefácio}

Inicialmente gostaria de agradecer o convite de Maximiliano Loiola Ponte de Souza para escrever o prefácio de um livro que reúne uma série de trabalhos dedicados a descrever e analisar as características específicas dos diversos modos de uso de álcool em diferentes povos indígenas brasileiros. Agradeço ainda a utilização por parte dos colegas brasileiros de alguns conceitos que elaborei no princípio da década de 1980. A sua aplicação em contextos diferentes daqueles em que trabalhei no México permite-me observar a uma maior distância - e talvez com maior objetividade - suas potencialidades metodológicas e analíticas.

Processos de Alcoolização Indígena no Brasil reúne uma série de trabalhos produzidos a partir de enfoques de diferentes disciplinas e orientações, entretanto, entre eles a complementaridade predomina sobre as diferenças. Como bem sabemos, os enfoques biomédicos vêm destacando os aspectos patológicos do consumo de álcool, ao passo que as investigações socioantropológicas vêm focalizando os aspectos integradores e não patológicos desta substância. Em outras palavras, a maior parte da produção antropológica vem negando ou deixando em segundo plano a relação entre álcool e alcoolismo.

Enquanto a maioria dos trabalhos biomédicos considera como naturais as consequências patológicas do consumo de álcool, as investigações antropológicas tendem a subestimar as consequências negativas associadas ao uso desta substância. Considero que essa polarização limita a potencialidade descritiva e analítica de ambas as perspectivas Não obstante, assumo que os questionamentos antropológicos - principalmente sua frequente exclusão do patológico - têm sido úteis não apenas para repensar o 'alcoolismo' e contribuir para a construção do enfoque de redução de danos, mas especialmente para destacar a necessidade de se explicitarem os pressupostos teóricos, metodológicos, e também ideológicos, que utilizamos em nossos estudos e intervenções.

Portanto, uma das principais contribuições epistemológicas do trabalho antropológico se constitui no questionamento dos conceitos que consideramos como óbvios e de aceitação mais ou menos universal. De fato, álcool, alcoolismo e processo 
de alcoolização são conceitos estreitamente relacionados, mas não intercambiáveis. A diferenciação e a contextualização desses conceitos evitariam alguns dos mais frequentes 'mal-entendidos' que ocorrem ao serem utilizados.

O álcool é uma substância química caracterizada por uma série de propriedades, cujas consequências e funções operam basicamente a partir dos usos sociais, econômicos e obviamente psicológicos produzidos pelos diferentes grupos. Isso significa dizer que o uso de álcool per se pode gerar algumas consequências patológicas no nível físico e/ou psíquico, em função das características de seu consumo e da vulnerabilidade dos sujeitos (cirrose hepática, intoxicação ou delirium tremens). Mas a maioria dos efeitos negativos não seria produto do consumo do álcool em si. Os homicídios, as agressões intrafamiliares e os acidentes não são consequências necessárias do consumo de álcool, mas sim comportamentos possíveis, considerados mais ou menos estimulados e/ou aceitos por diferentes sociedades, realizados por sujeitos específicos.

A identificação e a autoidentificação de grupos étnicos ou de classes sociais com o 'alcoolismo', assim como as estigmatizações ou relações de hegemonia/ subalternidade desenvolvidas em torno do álcool e do alcoolismo, são construções sociais geradas por meio de processos econômicos e políticos e/ou ideológicos/ culturais. Assim, a descrição das condições que caracterizam o consumo de álcool permitiria entender tanto determinadas consequências patológicas como a funcionalidade sociocultural desse mesmo uso. São essas condições - e não o ato de ingestão - que possibilitarão compreender a agressividade ou a estigmatização, tanto em nível individual como coletivo. Destaca-se que não é o caso de se negar o papel do sujeito, mas sim de alertar para necessidade de pensá-lo em articulação com processos socioculturais e/ou político-econômicos.

No nosso entendimento, o álcool é, em determinados contextos, basicamente um instrumento, um meio, aparentemente imprescindível, para a concretização de relações e rituais sociais. Além disso, a pesquisa socioantropológica vem mostrando a quantidade e a variedade de funções que o álcool adquire em diferentes grupos sociais (Cortes, 1988). É desse ponto de vista que é possível compreender que o álcool pode cumprir em grupos étnicos mexicanos e brasileiros funções psicotrópicas, terapêuticas, alimentares, de sociabilidade, de coesão e integração cultural, de identificação e pertencimento social, de transgressão ou de 'válvula de escape', tomando parte em rituais religiosos, profissionais e/ou familiares. Mas também pode funcionar como instrumento de controle social, de exploração econômica, de justificativas racistas, ou de legitimador de violências intrafamiliares.

Além disso, o álcool pode ter, simultaneamente, efeitos negativos e positivos tanto para os sujeitos como para os grupos sociais. E é justamente nessa complexidade, devidamente explorada por vários autores deste livro, que se ancora o conceito de processo de alcoolização. 
Este conceito não apenas destaca as funções positivas dos usos do álcool, mas também reconhece que seu consumo, direta ou indiretamente, relaciona-se a um conjunto de agravos que constituem as principais causas de morbimortalidade tanto para a população em geral, como para grupos étnicos em particular.

Em países como os Estados Unidos e o Canadá são os grupos étnicos o segmento populacional que apresenta as taxas mais altas de mortalidade por cirrose hepática. No caso dos povos indígenas dos Estados Unidos, quatro de suas dez principais causas de morte - acidentes, cirrose hepática, homicídio e suicídio estão associadas ao consumo de álcool. O 'abuso' de álcool está relacionado com $38 \%$ de mortes entre eles, enquanto para o restante da população dos Estados Unidos representa somente 7,8\% (NIAAA, 1985).

Contudo, tanto os aspectos positivos como os negativos devem ser relacionados aos usos sociais das bebidas alcoólicas. E são esses usos pensados simultaneamente em termos contraditórios e complementares, que nos permitirão entender porque uma substancia produzida e disseminada pelos grupos dominantes foi apropriada pela maioria dos grupos étnicos até constituir-se em parte substantiva de suas identidades culturais mais profundas.

\section{A necessária articulação de perspectivas diferentes}

Meu interesse pelo estudo do 'alcoolismo' e do processo de alcoolização se relaciona em grande medida às minhas preocupações com a estrutura e as funções do saber médico, que deu lugar a vários estudos nos quais descrevi e analisei determinadas limitações do que é denominado, desde os fins da década de 1970, de 'modelo médico hegemônico' (Menéndez, 1990; Menéndez G Di Pardo, 1996). Ressalto que minhas análises, embora críticas em relação à biomedicina buscam impulsionar a necessária complementaridade entre as perspectivas biomédicas e aquelas desenvolvidas a partir da antropologia social.

De acordo com dois dos mais importantes especialistas em adições, os estudos epidemiológicos sobre alcoolismo raramente têm,

abordado as verdadeiras dificuldades teóricas desta problemática [uma vez que] predomina um tipo de investigação mecânica e reiterativa que trata o usuário de drogas como um objeto de estudo totalmente dissociado das condições culturais e das instituições sociais dentro das quais vive e consome drogas. (Edwards G Ariff, 1981: 291)

Essas 'antigas' conclusões continuam válidas para a maior parte das pesquisas epidemiológicas que se realizam, pelo menos no México, sobre o consumo de álcool e suas consequências. Entretanto, é este o ponto que agora me interessa destacar, grande parte dessa produção epidemiológica apresenta ainda sérias 
incongruências e limitações metodológicas, especialmente relacionadas à qualidade da informação que produz e analisa.

Pelo menos desde a década de 1960 contamos com avaliações metodológicas que indicam que os estudos epidemiológicos tendem a sub-registrar o consumo de bebidas alcoólicas por parte da população. Room e Collins (1983) analisaram dados de uma pesquisa realizada nos Estados Unidos, conduzida por Cahalan nos anos de 1964/65, na qual o autor usava entrevistas de autorrelato de consumo de bebidas alcoólicas. Os autores demonstram que, utilizando essa estratégia, Cahalan conseguiu identificar apenas 50\% do volume de vinhos comercializado no período, 55\% do de cerveja e 55\% do das bebidas de alto teor alcoólico. Isso significa que o estudo sub-registrou mais de $50 \%$ do volume de bebidas alcoólicas consumido pela população daquele país, segundo os registros de venda.

Estudos análogos foram conduzidos no Canadá, Finlândia e novamente nos Estados Unidos, concluindo que os inquéritos epidemiológicos baseados em entrevistas de autorrelato de consumo de bebidas alcoólicas "proporcionam estimativas do consumo per capita entre 40 e 60\% dos resultados obtidos pela venda" (OMS/Opas, 2000: 36). Estas e outras pesquisas realizadas durante as décadas de 1980 e 1990 concluíram que os estudos epidemiológicos teriam dificuldades para detectar os bebedores que apresentam consumo mais intenso. Isso significa dizer que esses bebedores tenderiam a dizer para os entrevistadores que não consomem álcool ou que o consomem em muito pouca quantidade.

Ainda que os especialistas mexicanos tenham conhecimento dessas críticas aos estudos epidemiológicos sobre o alcoolismo, no final da década de 1980, foram realizados cinco estudos em âmbito nacional sobre o consumo de álcool e outras drogas. Entretanto, em nenhum deles havia considerações metodológicas a respeito do sub-registro que os instrumentos epidemiológicos tendem a produzir, tanto na população em geral, quanto em certos grupos de risco em particular.

O sub-registro também é observado nos estudos sobre violência contra mulher que buscam correlacionar esse agravo ao consumo de álcool. Por exemplo, em um estudo sobre violência contra a mulher, realizado pelo Instituto Nacional de Saúde Pública do México, se encontraram os seguintes achados: 51\% das mulheres entrevistadas disseram que nunca consumiram bebidas alcoólicas; $43,6 \%$ informaram que bebiam ocasionalmente menos de uma vez ao mês; e somente $3 \%$ delas reconheceu um consumo maior ao de uma vez ao mês. O interessante é que os pesquisadores descreveram e analisaram esses dados como se fossem 'verdades' estatísticas (Olaiz, Rico G Del Río, 2003). Eles nem sequer compararam os dados obtidos com as informações clínicas e estatísticas fornecidas pelo próprio setor saúde, o que talvez poderia fazê-los duvidar dos dados obtidos nas entrevistas. A Secretaria de Saúde do México informa que, desde a década de 1980, a cirrose 
hepática se configura como uma das cinco principais causas de morte entre mulheres de 35 a 64 anos.

Há mais de trinta anos fazem-se críticas consistentes a respeito das construções mais ou menos imaginárias que são produzidas por várias disciplinas a respeito do alcoolismo (Room G Collins, 1983). Mas a maioria de nossos especialistas continua sem levar em consideração essas críticas, e continuam estabelecendo medições que não apenas não são válidas em múltiplos aspectos, mas que distorcem gravemente a realidade.

Essas críticas ao manejo de dados estatísticos a respeito do alcoolismo não negam a importância da produção epidemiológica, mas buscam evidenciar a necessidade de desenvolver estudos do tipo qualitativo que complementem e reorientem os estudos de tipo estatístico.

Considero que o conjunto de trabalhos que integram este livro se caracterizam não só pela sua complementaridade, por pensar o alcoolismo como processo de alcoolização e por aplicar enfoques qualitativos, mas, sobretudo, por apresentar aportes descritivos e teóricos com base em diferentes disciplinas e experiências profissionais, o que possibilita ter um panorama abrangente do processo de alcoolização em, pelo menos, certos povos indígenas do Brasil. É por meio desses tipos de estudos, articulados a trabalhos estatísticos orientados teoricamente pelo conceito de processo de alcoolização, que poderemos desenhar estratégias de ação específicas que reduzam as consequências negativas do consumo de álcool e recuperem suas funções positivas.

Eduardo L. Menéndez

Professor titular do Centro de Investigaciones y Estudios Superiores en Antropología Social (México)

\section{Referências}

CORTES, B. La funcionalidad contradictoria del consumo colectivo de alcohol. Nueva Antropología, 34:157-186, 1988.

EDWARDS, G. G. ARIFF A. Los Problemas de la Droga en el Contexto Sociocultural. Ginebra: Organización Mundial de la Salud, 1980.

MENÉNDEZ, E. L. Morir de Alcohol: saber y hegemonía médica. México: Alianza Editorial Mexicana/Fonca, 1990.

MENÉNDEZ, E. L. G DI PARDO, R. B. De Algunos Alcoholismos y Algunos Saberes: atención primaria y proceso de alcoholización. México: Ciesas, 1996.

NATIONAL INSTITUTE ON ALCOHOL ABUSE AND ALCOHOL (NIAAA). Alcohol and Native Americans Alcohol Topics: research review. Rockville, 1985. 
OLAIZ, G.; RICO, B. G DEL RÍO, A. Encuesta Nacional sobre Violencia Contra la Mujer. México: Instituto Nacional de Salud Pública, 2003.

ORGANIZACIÓN MUNDIAL DE LA SALUD/ORGANIZACIÓN PANAMERICANA DE LA SALUD (OMS/OPAS). Guía Internacional para Vigilar el Consumo de Alcohol y sus Consecuencias Sanitarias. Washington DC: Opas, 2000.

ROOM, R. G COLLINS, G. Alcohol and Desinhibition: nature and meaning of the link. Rockville: National Institute on Alcohol Abuse and Alcoholism, 1983. 


\section{Apresentação}

Nos últimos anos, vem ocorrendo no Brasil a proliferação de estudos que enfocam, de um modo ou de outro, a saúde dos povos indígenas. Utilizando os termos de pesquisa indigenous health Brazil, na plataforma Medline (<www.ncbi.nlm.nih.gov/pubmed>), encontram-se 58 artigos publicados no período de 2007 a 2011 que abordam essa temática. Uma breve análise de tal acervo, tomado como proxy da produção científica sobre a questão em pauta, pode servir de parâmetro para se conhecer, mesmo que de forma aproximada, a agenda de pesquisa sobre a área.

Considerando o objeto central dos artigos, observa-se que 15 (25,9\%) tratam de aspectos relacionados a doenças infectoparasitárias e 8 (13,8\%), à nutrição/ alimentação. Sobre saúde bucal, demografia, políticas públicas de saúde e doenças crônico-degenerativas, constata-se um número igual de textos, 6 (10,3\%).

A expressiva proporção de artigos relacionados a doenças infecciosas e demografia não causa nenhuma surpresa. Coimbra Jr. e Santos (2000) assinalam que esses temas, há muito, caracterizam a agenda nacional de pesquisa sobre a saúde dos povos indígenas brasileiros. Por sua vez, observa-se o interesse crescente de pesquisadores por questões relacionadas às mudanças nos modos de vida das sociedades indígenas, bem como aos impactos e especificidades dos processos de transição epidemiológica e nutricional. Isso pode explicar a maior atenção direcionada às doenças crônico-degenerativas, à nutrição/alimentação e até mesmo à saúde bucal. A quantidade de artigos sobre políticas de saúde indígena parece representar os esforços em analisar os percalços da implantação da Política Nacional de Saúde dos Povos Indígenas, promulgada em 2002 (Brasil, 2002).

Considerando o âmbito dessa publicação, verifica-se que apenas um artigo $(1,7 \%)$ focaliza o uso de álcool por povos indígenas brasileiros. Entretanto, é maior o número de textos acerca de concepções e práticas nativas sobre o processo saúdedoença $(4 ; 6,9 \%)$, uso de medicamentos $(2 ; 3,4 \%)$ e saúde mental $(2 ; 3,4 \%){ }^{1}$

Cabe ainda ressaltar que, na citada Política Nacional de Saúde dos Povos Indígenas (Brasil, 2002), o alcoolismo e sua relação com a violência aparecem entre 
as sete situações especiais a serem prioritariamente enfrentadas, dada sua complexidade e relevância sanitária. Ademais o objetivo geral da área de Intervenção em saúde mental, do componente II, do projeto Vigisus ${ }^{2}$ era:

Desenvolver estratégias de intervenção e avaliação para o enfrentamento do problema do alcoolismo e suicídio nas populações indígenas com vistas a subsidiar a formulação de uma política de saúde mental para o subsistema de saúde indígena. (Brasil, 2005: 70, grifo meu)

Note-se que doze projetos de intervenção e/ou de pesquisa sobre uso de bebidas alcoólicas foram selecionados para financiamento total ou parcial com recursos do Vigisus II, durante o período de 2005-2008. Por fim, também é importante frisar que o alcoolismo foi considerado uma das 'situações especiais de enfrentamento' da Política de Atenção Integral à Saúde Mental das Populações Indígenas (Brasil, 2007).

Assim, reconhece-se, de um lado, que o alcoolismo é um importante problema de saúde pública entre os povos indígenas brasileiros; de outro, comprovase a pequena produção acadêmica sobre o uso do álcool e dos problemas a ele relacionados. Tais aspectos não só justificam a publicação desta coletânea, mas também levam a investigar as razões do descompasso.

Um possível caminho explicativo seria atentar para o fato de que a investigação do uso de álcool por indígenas é um grande desafio teórico e metodológico (Oyacer G Ñanco, 1998; Kunitz G Levy, 1994), visto que se trata de um tema, ao mesmo tempo, estigmatizador e complexo. Demanda, por isso, um refinamento conceitual que permita tanto superar os preconceitos do senso comum, quanto promover um diálogo entre diferentes campos disciplinares. Ou seja, uma interlocução entre saberes necessários para compreender as múltiplas facetas do consumo de bebidas alcoólicas entre grupos culturalmente diferenciados.

Apenas para exemplificar essa dificuldade teórico-conceitual faço uma breve digressão a respeito de uma experiência vivida por mim há mais ou menos oito anos, quando estive em Brasília para participar de uma discussão sobre a questão do uso de bebidas alcoólicas entre os povos indígenas brasileiros.

Recordo-me que as falas daqueles que me antecederam pareciam interessantes, embora, confesso, pouco compreensíveis para mim. Abordavam questões culturais, como organização do trabalho, festas, parentesco etc. E, para meu espanto, alguns palestrantes terminavam afirmando que o 'alcoolismo' naquele povo indígena específico poderia ser compreendido com base naqueles pontos apresentados. Eu pensava: 'alcoolismo'? Falaram de 'alcoolismo'? Que critérios diagnósticos estavam usando? 
Sendo médico psiquiatra, com alguma experiência em atender pacientes procedentes de áreas indígenas em um manicômio em Manaus, e tendo no currículo uma (única) ida de quinze dias ao campo, como parte da primeira etapa de minha dissertação de mestrado, que iria abordar a questão do uso do álcool em povos indígenas do Alto Rio Negro, julgava-me uma autoridade no assunto. Como eu havia sido convidado, pressupus que seria para abordar adequadamente os conceitos de 'alcoolismo' (que de fato entendia como a categoria biomédica dependência do álcool, o que não é verdadeiro, como pretendo evidenciar a seguir).

Em minha apresentação, em tom quase professoral, tratei de apresentar critérios biomédicos (que julgava como corretos e únicos, obviamente), tentando esclarecer que não se podia chamar determinados modos de beber de 'alcoolismo' sem levar em consideração certos critérios.

O fato é que, com toda a gentileza possível nesses momentos de embate conceitual, os demais presentes demonstraram a ideia de reducionismo biomédico, tomando-me como exemplo prototípico. De fato não me lembro se disse, ou se apenas pensei, que se eu era reducionista (um insulto para um psiquiatra que é representado como o especialista 'mais mente aberta' da área médica), eles não tinham critérios para abordar o uso de álcool.

No caso da experiência mencionada, profissionais de diferentes campos do saber comunicavam-se usando uma mesma expressão - 'alcoolismo' (a mesma que por sinal consta nos documentos do Ministério da Saúde anteriormente citados) que por sua vez é carregada de representações negativas, pejorativas e até mesmo acusatórias (Neves, 2004). Analisando a questão do uso de bebidas alcoólicas com base nos pressupostos de suas próprias disciplinas e usando uma mesma palavra para se referir a aspectos diversos, criou-se uma barreira de comunicação quase intransponível.

Vimos propondo, já há algum tempo, que um primeiro passo para qualificar as pesquisas, os diálogos interdisciplinares e as intervenções nesta área seria deixar de usar a expressão 'alcoolismo' (Souza G Garnelo, 2006). ${ }^{3}$ De fato, tal proposição não é nova, visto que esta categoria tem sua própria historicidade no campo biomédico que a cunhou. Teve sua proposição inicial, suas transformações, seu apogeu e sua entrada em desuso, conforme pode ser observado na leitura crítica da história da categoria no cenário biomédico feita por Bertolote (1997).

O termo alcoolismo foi cunhado por Magnus Huss em 1849 e deveria ser entendido como um quadro de intoxicação crônica pelo álcool. Sua descrição baseava-se exclusivamente nas consequências do uso do álcool nos diferentes órgãos e sistemas do indivíduo. Em 1931, o Royal College of Physicians, de Londres, promoveu uma inovação ao incluir o alcoolismo no grupo das doenças mentais, deixando de classificá-lo como uma doença geral ou constitucional. Tal opção passa a ser aceita pela Organização Mundial da Saúde (OMS) a partir de 1948. Em 
1977, a OMS deixa de usar o termo e surge oficialmente a categoria 'dependência do álcool'. Os atuais códigos de classificação dos transtornos mentais abandonaram 'alcoolismo', tanto pela imprecisão conceitual quanto pelo preconceito associado à expressão, tornando-a uma categoria de reduzido valor heurístico.

A despeito desse fato, nota-se ainda, pelo menos no cenário nacional, o emprego recorrente do termo alcoolismo por pesquisadores que investigam o consumo do álcool por povos indígenas. ${ }^{4}$ Pesquisadores oriundos das ciências sociais, em particular, atribuem ao termo outros significados, ou partem dele para tecer críticas ao já comentado e experienciado reducionismo biomédico. Por sua vez, os pesquisadores da área da saúde tendem a considerar alcoolismo simplesmente como sinônimo de dependência do álcool.

No entanto, tão somente abandonar o termo alcoolismo não resolve o impasse, na medida em que se pode passar a utilizar uma miríade de termos correlatos menos estigmatizantes, sem que necessariamente se amplie o valor analítico dessas categorias. Soluciona-se apenas o problema no nível do 'politicamente correto', mas não do enfoque teórico-metodológico.

Assim, apresenta-se, a seguir, um conjunto de categorias (dependência do álcool, problemas relacionados ao uso de álcool e alcoolização) e suas articulações (Figura 1), no sentido de contribuir para o refinamento conceitual anteriormente apontado como necessário.

Ademais, ao adentrar nesta seara, será explicado ao leitor o título deste livro, que, mais do que um enunciado elegante ou chamativo, pretende conter em si os princípios norteadores que conferem unidade, apesar de construída a posteriori, à diversidade dos textos aqui reunidos. Com isso, busca-se indicar as dimensões do beber que são de fato abordadas pelos autores, o que, em última análise, é o propósito principal desta apresentação.

Figura 1 - Proposta de um modelo para interação dos conceitos de alcoolização, problemas relacionadas ao uso de álcool e dependência do álcool

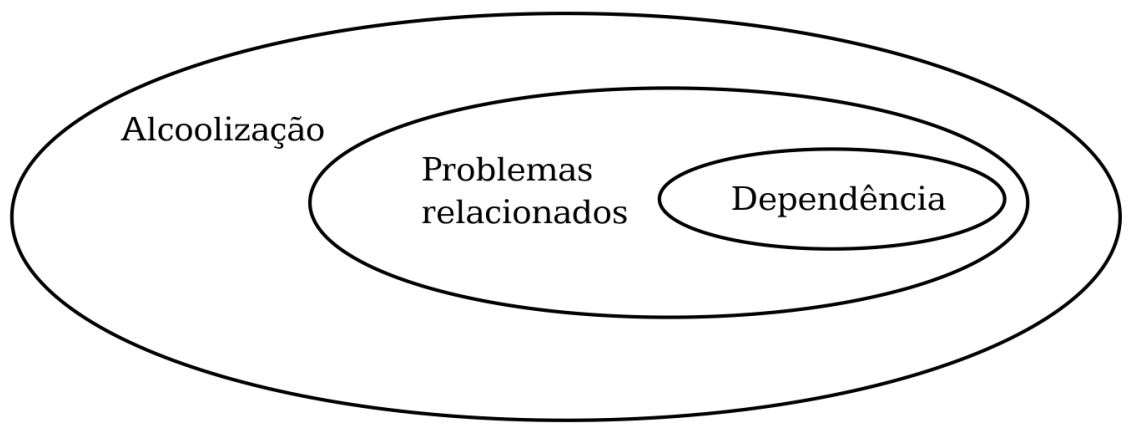

Fonte: Souza G Garnelo, 2006: 287. 
A primeira categoria, 'dependência do álcool', é a mais restrita e potencialmente útil em estudos de corte biomédico, sejam clínicos ou epidemiológicos. Diz-se que há 'dependência' quando é possível identificar, em um indivíduo que consome bebidas alcoólicas, um padrão de ingesta que pode ser associado a indícios de dependência química (tolerância e sintomas de abstinência); descontrole em relação ao uso da substância; problemas de ordem física, psíquica e/ou social decorrentes da utilização de bebida (OMS, 1993; APA, 1995). Evidências genéticas e bioquímicas de diversos matizes (Schuckit, 1984; Amit G Smith, 1985) e a extensa adoção dos princípios dos grupos de Alcoólicos Anônimos ancoram, de certa forma, a aceitação desta categoria biomédica. Porém, tendo pretensões universais e não levando em consideração especificidades socioculturais associadas ao consumo de álcool, a aplicabilidade desta categoria torna-se limitada em certos contextos indígenas (Kunitz G Levy, 1994; Souza G Garnelo, 2006; Souza G Garnelo, 2007).

Note-se que os textos que compõem este livro, embasados em pressupostos teórico-metodológicos das ciências sociais, não adotam, explícita ou implicitamente, a categoria dependência do álcool. O leitor não encontrará pesquisas sobre prevalência de dependência do álcool, fatores de risco ou de enfoque clínico, seja médico ou psicológico. O foco dos capítulos não está no indivíduo, mas nos grupos sociais. Pretende-se, aqui, ressaltar, explorar e compreender as especificidades dos diferentes modos de beber de diferentes povos indígenas e não minorá-las, subsumindo-as em categorias supostamente totalizadoras.

A compreensão de que existem diversos aspectos relacionados ao consumo de bebida que extrapolam o cenário biomédico de dependência está associada ao avanço da aplicação das ciências sociais na área da saúde (Bertolote, 1997). Nessa colaboração, vem se construindo o conceito de 'problemas relacionados ao uso de álcool', que pode ser caracterizado como o conjunto dos efeitos - percebidos e vivenciados como adversos - associados ao uso do álcool, independentemente do fato de o padrão de ingesta configurar um quadro de dependência.

É fundamental entender que, com essa categoria, busca-se uma aproximação com categorias nativas (êmicas) para determinar quando o consumo de bebidas alcoólicas torna-se, sobretudo socialmente, um problema de fato. Dessa forma, o campo de investigação sobre o uso de álcool, dada a sua própria natureza, é aberto e polimorfo, visto que a fronteira que separa um beber normal de um problemático está estreitamente relacionada às dimensões socioculturais e históricas do beber (Edwards, Marshall G Cook, 1999). Neste livro, os autores que abordam os efeitos adversos do uso de bebidas alcoólicas se alinham implicitamente à categoria 'problemas relacionados ao uso de álcool', sobretudo porque buscaram se aproximar das categorias nativas de quando o beber se torna um problema.

Já o conceito de 'alcoolização', ou 'processo de alcoolização', é mais amplo. Engloba, de certa forma, os conceitos anteriores, contrapondo-se às tendências de 
centralizar as pesquisas em aspectos considerados problemáticos, sem investigar o papel do consumo de álcool em um dado contexto cultural. Menéndez, autor citado diversas vezes nos textos desta coletânea, propõe a categoria 'processo de alcoolização', entendida como

o conjunto de funções e consequências positivas e negativas que cumpre a ingesta de álcool para conjuntos sociais estratificados e não apenas o estudo dos alcoólicos dependentes, nem os excessivos, nem os moderados, nem os abstêmios, mas sim o processo que inclui a todos e que evita considerar o problema em termos de saúde e/ou enfermidade mental. (Menéndez, 1982: 63)

O conceito de alcoolização traz, de forma clara, a necessidade de contextualizar a prática de consumo de álcool na cultura e na história, e não apenas o uso problemático, buscando, em última instância, apreender o significado cultural atribuído ao consumo de bebidas alcoólicas e às motivações para beber, às situações de consumo e aos circuitos de embebedamento. O conceito de alcoolização e/ou os pressupostos a ele relacionados são ativamente recrutados, de modo explícito ou não, pelos diferentes autores, para subsidiar a compreensão dos modos de beber dos povos indígenas brasileiros, em uma perspectiva que se baseia tanto na organização social desses povos, quanto em sua história de contato com a sociedade nacional.

Fica, assim, evidenciado o posicionamento teórico que perpassa os textos desta coletânea e justificado o seu título: Processos de Alcoolização Indígena no Brasil. A expressão encontra-se no plural para destacar o entendimento de que existe uma diversidade de contextos nos quais os povos indígenas fazem uso de álcool, e que cada um deles tem suas especificidades. Conceber que um país caracterizado pela diversidade étnica indígena, com diversas experiências de contato e com distintos modos de interação com a sociedade nacional, possa ter um único processo de alcoolização seria incoerente com o próprio conceito adotado.

Para completar a apresentação, é preciso atentar para o subtítulo da obra: perspectivas plurais. O intento central desta publicação era fazer que o trabalho, de algum modo, se aproximasse da diversidade de contextos indígenas brasileiros, das diferentes estratégias teórico-metodológicas possíveis de serem utilizadas e das diferentes facetas da temática.

Para isso, os capítulos abordam contextos bastante distintos, tais como os indígenas do Alto Rio Negro e os da região do Uaçá, ambos localizados na região Amazônica; os Bororo do Centro-Oeste; os Pankararu do Nordeste; os Maxakali de Minas Gerais e os Guarani de Angra dos Reis, da região Sudeste; e os Kaingang e Mbyá-Guarani, do sul do país. Por sua vez, os autores provêm de diferentes campos disciplinares, de modo que há historiadores, antropólogos, sociólogos, psicólogos (clínicos, sanitaristas e psicanalistas), médicos (psiquiatras e sanitaristas), 
educadores, teólogos, entre outros, evidenciando o caráter multidimensional do objeto em análise.

Por fim, os textos foram selecionados de modo a abarcar uma pluralidade de questões, consideradas relevantes, relacionadas ao uso de álcool por povos indígenas. Tais questões serviram de base também para a ordenação dos capítulos.

O primeiro capítulo, de Esther Jean Lagdon, tem um caráter introdutório. Apresenta uma extensa revisão da literatura internacional e nacional sobre a questão do uso de bebidas alcoólicas, buscando, sobretudo, evidenciar a perspectiva antropológica sobre a questão.

Os capítulos 2 e 3 , de um modo bastante livre, podem ser denominados 'históricos'. O segundo, escrito por João Azevedo Fernandes, procura demonstrar que um caminho interessante e pouco explorado para se compreender a história de contato é a investigação das transformações na 'experiência etílica' nas sociedades ameríndias. O terceiro capítulo, de Manuel Ignacio Quiles, descreve uma investigação sobre o papel do álcool no processo histórico de contato dos Bororo e as consequências desses fatos na sua 'personalidade', buscando, em uma perspectiva 'etnopsicológica', compreender a forma contemporânea de uso de bebidas alcoólicas pelos indígenas desse grupo.

O capítulo 4 - de Maximiliano Loiola Ponte de Souza e Luiza Garnelo - e o capítulo 5 - de Maximiliano Loiola Ponte de Souza, Suelly Ferreira Deslandes e Luiza Garnelo - apresentam descrições e análises sobre o processo de alcoolização entre povos indígenas da região do Alto Rio Negro; o segundo com um enfoque específico sobre os jovens.

No capítulo 6, Laércio Fidelis Dias apresenta uma etnografia que aborda os aspectos sociais e simbólicos do consumo de bebidas alcoólicas entre os povos indígenas do Uaçá. Saindo do contexto amazônico e adentrado no cenário nordestino, Moab Duarte Acioli, no capítulo 7, faz um estudo sobre os Pankararu, visando a compreender os diferentes sentidos atribuídos por esse povo indígena ao uso de bebidas alcoólicas. No capítulo 8, João Luiz Pena explora como as bebidas 'de alto teor alcoólico', introduzidas pelos não indígenas nas guerras de conquista, foram simbolicamente incorporadas pelos Maxakali em suas próprias estruturas culturais.

Os quatro textos seguintes têm em comum o fato de abordarem, mesmo que de modos diversos, diferentes 'estratégias de enfrentamento' dos problemas relacionados ao uso de álcool por povos indígenas. No capítulo 9, Ari Ghiggi Junior e Esther Jean Langdon fazem uma ponte com os três capítulos anteriores, ao apresentar uma etnografia sobre os significados Kaingang a respeito do uso problemático de álcool e das estratégias por eles utilizadas para lidar com esse comportamento desviante, as chamadas 'práticas de autoatenção'. No capítulo 10 , de Maximiliano Loiola Ponte de Souza, mostram-se as diferenças entre as ações de prevenção de doenças e as de promoção da saúde, tendo como fio condutor a 
questão do uso de álcool por povos indígenas, evidenciando as dificuldades de transposição direta de estratégias utilizadas em outras realidades para esse contexto. A seguir, no capítulo 11, de Luciane Ouriques Ferreira, tem-se a descrição e a análise crítica de iniciativas locais indígenas para lidar com os problemas relacionados ao uso de álcool, conduzidas por conhecedores tradicionais das práticas de cura e cuidado mbyá-guarani. No capítulo 12, Maria de Betania Garcia Chaves, Andrey Moreira Cardoso e Salette Maria Barros Ferreira descrevem uma experiência de atuação dos serviços públicos de saúde na abordagem, diferenciada e culturalmente sensível, dos problemas relacionados ao uso de álcool entre os Guarani de Angra dos Reis.

Por fim, demarcando e ratificando a importância do protagonismo indígena no enfrentamento dos problemas relacionados ao uso de bebidas alcoólicas, o capítulo 13, do educador e padre salesiano Justino Sarmento Rezende, indígena Tuyuca, apresenta uma reflexão baseada em suas experiências pessoais a respeito dos problemas relacionados ao uso de álcool no contexto escolar indígena atual.

Para encerrar esta apresentação, gostaria de agradecer aos autores dos capítulos por sua dedicação, aos editores dos periódicos ou pessoas em cargos correlatos que permitiram a republicação dos textos não inéditos e à Editora Fiocruz pela confiança em mim depositada para organizar esta coletânea. Expresso, ainda, a minha expectativa de que este livro facilite o diálogo interdisciplinar e possa vir a fornecer subsídios para ações intersetoriais, concebidas de forma dialógica, para enfrentar os problemas relacionados ao uso de álcool que em alguns contextos indígenas constituem importantes problemas sociais e de saúde pública.

O organizador

Notas

1 Ao se realizar busca semelhante, na base de dados SciELO (<www.scielo.br $>$ ), considerando o mesmo intervalo de tempo e utilizando os termos 'saúde indígena', encontram-se 64 artigos. As principais temáticas abordadas foram: demografia $(14 ; 21,9 \%)$, doenças infectoparasitárias (11; 17,2\%), políticas públicas de saúde $(11 ; 17,2 \%)$, nutrição/alimentação (9; 14,1\%), concepções nativas sobre o processo saúde-doença $(5 ; 7,8 \%)$, saúde bucal $(4 ; 6,3 \%)$ e saneamento (3; 4,7\%). Apenas dois $(3,1 \%)$ trataram da temática do uso de álcool entre os povos indígenas. Em síntese, não há diferenças substantivas em relação aos números encontrados no Medline.

2 Esse projeto visava a promover a modernização do sistema nacional de vigilância em saúde.

3 A argumentação que segue é amplamente apoiada nesse texto.

4 Ilustra esse ponto de vista o título de um evento realizado em 2001: "Seminário sobre alcoolismo e DST/Aids entre os povos indígenas". Os anais do evento (<www.fef.br/biblioteca/arquivos/ 
data/57seminario_alcoolismo.pdf $>$ ) constituem o primeiro conjunto de textos a abordar, de forma sistemática, a questão do uso de álcool entre povos indígenas brasileiros. Aos autores dos textos, aos idealizadores e organizadores do seminário, rende-se aqui a devida homenagem e reconhece-se a sua primogenitura.

Referências

AMERICAN PSYCHIATRIC ASSOCIATON (APA). Manual Diagnóstico e Estatístico de Transtornos Mentais - DSM IV. Porto Alegre: Artes Médicas, 1995.

AMIT, Z. G SMITH, B. R. A multidimensional examination of positive reinforcing properties of acetaldehyde. Alcohol, 2: 367-370, 1985.

BERTOLOTE, J. M. Conceitos em alcoolismo. In: RAMOS, S. P. G BERTOLOTE, J. M. (Orgs.). Alcoolismo Hoje. 3. ed. Porto Alegre: Artes Médicas, 1997.

BRASIL. Fundação Nacional de Saúde. Política Nacional de Atenção à Saúde dos Povos Indígenas. 2. ed. Brasília: Ministério da Saúde, Fundação Nacional de Saúde, 2002.

BRASIL. Ministério da Saúde. Projeto Vigisus II: modernização do Sistema Nacional de Vigilância em Saúde. Brasília: Ministério da Saúde, 2005. (Componente II - Saúde indígena).

BRASIL. Ministério da Saúde. Portaria n. 2.759, 25 out. 2007. Estabelece diretrizes gerais para a Política de Atenção Integral à Saúde Mental das Populações Indígenas e cria o Comitê Gestor Brasil. Disponível em: <bvsms.saude.gov.br/php/index.php>. Acesso em: out. 2012.

COIMBRA JR., C. E. A G SANTOS, R. V. Saúde, minorias e desigualdade: algumas teias de inter-relações, com ênfase nos povos indígenas no Brasil. Ciência G Saúde Coletiva, 5(1): 125-132, 2000.

EDWARDS, G.; MARSHALL, E. J. G COOK, C. C. H. O Tratamento do Alcoolismo: um guia prático para profissionais de saúde. 3. ed. Porto Alegre: Artes Médicas, 1999.

KUNITZ, S. J. P. G LEVY, J. E. Drinking Careers: a twenty-five-year study of three Navajo populations. New Haven, London: Yale University Press, 1994.

MENÉNDEZ, E. L. El proceso de alcoholización: revisión crítica de la producción socioantropológica, histórica y biomédica en América Latina. Revista Centroamericana de Ciencias de la Salud, 22: 61-94, 1982.

NEVES, D. P. Alcoolismo: acusação ou diagnóstico? Cadernos de Saúde Pública, 20:7-36, 2004.

ORGANIZAÇÃO MUNDIAL DA SAÚDE (OMS). Classificação de Transtornos Mentais e de Comportamento da CID-10. Porto Alegre: Artes Médicas, 1993.

OYACER, A. M. G ÑANCO, J. Alcoholismo y etnía: críticas y propuestas. In: SALGADO, M. S. G MELLA, I. J. (Eds.). Salud, Cultura y Territorio: bases para una epidemiología intercultural. Lincanray: Ministerio de Salud Chile, 1998.

SCHUCKIT, M. A. Subjective responses to alcohol in sons of alcoholics and control subjects. Archives of General Psychiatry, 41: 879-883, 1984. 
SOUZA, M. L. P. G GARNELO, L. Desconstruindo o alcoolismo: notas a partir da construção do objeto de pesquisa no contexto da saúde indígena. Revista Latinoamericana de Psicopatologia Fundamental, IX(2): 279-292, 2006.

SOUZA, M. L. P. G GARNELO, L. Quando, como e o que se bebe: o processo de alcoolização entre populações indígenas do Alto Rio Negro, Brasil. Cadernos de Saúde Pública, 23(7):1640-1648, 2007. 


\section{O Abuso de Álcool entre os Povos Indígenas no Brasil: uma avaliação comparativa ${ }^{1}$}

A imagem negativa do índio bêbado expressa a representação estigmatizada que os membros desses grupos étnicos experimentam, frequentemente, nas suas interações com membros da sociedade envolvente. O abuso de álcool entre os povos nativos não é um fenômeno novo, tampouco limitado ao Brasil. Em outros países, particularmente nos Estados Unidos, Canadá e Austrália, o tema é enfocado em pesquisas, conferências e programas de saúde desde a década de 1960 (Everett, Waddell G Heath, 1976; Mandelbaum, 1965; MacAndrew G Edgerton, 1969). Porém, no Brasil, somente nos últimos 15 anos, foi percebido como um problema de alta relevância para os programas de saúde. Ainda há uma grande lacuna no que se refere ao conhecimento sobre a realidade do consumo de álcool entre os povos indígenas que vivem no território brasileiro e faltam pesquisas para dimensionar adequadamente o problema. $\mathrm{O}$ abuso de álcool está entre os maiores desafios enfrentados pelos índios atualmente, associado a outros como a violência social (Simonian, 1998; Souza, 2004, 2009), a precariedade nas condições de saúde, a transmissão de DST/Aids e altas taxas de suicídio em certos grupos, tais como os Kaiowá/Guarani e Tikuna (Erthal, 1998).

Este capítulo examina a questão de abuso do álcool e sua prevenção entre os povos indígenas na perspectiva antropológica (Douglas, 1987). Diferente da biomedicina e da psicologia, esta abordagem não define a síndrome de dependência do álcool (popularmente conhecida como alcoolismo) como um processo natural, isto é, como uma doença que ocorre igualmente em todos os seres humanos. O abuso do álcool é percebido como um fenômeno complexo, resultante de vários fatores, entre os quais o contexto sociocultural, que tem um papel determinante nas variações de comportamento relacionado à ingestão de etanol, a substância principal das bebidas alcoólicas.

As consequências desta perspectiva de análise são múltiplas: exige que se reexamine o entendimento da síndrome como doença; que reconheçamos a diversidade de estilos de beber entre os diferentes povos indígenas e, também, entre os vários grupos da mesma população; e, por fim, que as estratégias para 
contornar o problema sejam baseadas na participação da comunidade em todas as fases de pesquisa e ações práticas. ${ }^{2}$

Para distinguir a visão patológica do fenômeno da perspectiva antropológica, adoto o termo 'alcoolização' ou 'processo de alcoolização' para referirme a todos os processos sociais considerados decisivos na estruturação do alcoolismo como fenômeno patológico, normal e coletivo. Esse conceito foi sugerido por Eduardo Menéndez (1982, 1998), antropólogo com longa experiência de pesquisa e intervenção comunitária no México, e vem sendo adotado no Brasil para compreender as influências culturais e históricas nos modos de consumir álcool (Acioli, 2002; Ghiggi Jr., 2010; Souza, 2004; Souza G Garnelo, 2006).

\section{Biomedicina e síndrome de dependência ao álcool}

Segundo Maximiliano Souza e Luiza Garnelo (2006), o termo alcoolismo foi abandonado pela biomedicina, tanto por sua imprecisão conceitual quanto pelo preconceito associado a ele, e substituído por 'síndrome de dependência do álcool'. Ao discutir a definição desta patologia, surgem duas controvérsias sobre a sua natureza: 1) se a síndrome é um fenômeno unitário ou divergente; 2) se é verdade que não há cura: 'uma vez alcoolista, sempre alcoolista'. As respostas a essas indagações têm implicações importantes para o tratamento, porque se o consumo de álcool é um fenômeno heterogêneo, como argumentam as ciências sociais, é necessário entender as particularidades do abuso de álcool em cada situação para construir programas eficazes de prevenção.

Segundo a ótica da biomedicina, a resposta é afirmativa para as duas perguntas. A síndrome é definida como parte dos transtornos mentais relacionados ao abuso de substâncias e é conceituada como uma patologia que tem a mesma causa e se manifesta igualmente em todas as culturas. Esta síndrome, do modo como é definida pela Organização Mundial da Saúde (OMS) e pela medicina moderna, implica um comportamento crônico que, a partir de determinado momento, não é mais passível de ser interrompido espontaneamente, havendo, inclusive, o risco de uma crise aguda em casos de abstinência forçada, tal o nível de impregnação celular que transforma o próprio metabolismo básico do organismo (Quiles, 2000). O enfoque está no indivíduo, a causa é uma dependência biológica e, uma vez que a dependência se estabelece, o processo de doença segue um percurso determinado e inevitável. A dependência se desenvolve em uma única direção. Se não parar de beber, o doente irá morrer devido às consequências relacionadas ao consumo de álcool, tais como cirrose, acidentes de trânsito etc. Alguns cientistas argumentam que os índios, em virtude de uma herança genética, são mais susceptíveis à dependência biológica do que outras populações, mas Sherry Saggers e Dennis Gray (1998) argumentam que faltam evidências científicas conclusivas. 


\section{Estudos epidemiológicos comparativos}

Pesquisas realizadas por antropólogos fornecem dados importantes para responder negativamente às duas perguntas e ao possível fator genético. Como apresentado no Congresso Mundial das Ciências Antropológicas e Etnológicas, ocorrido em Chicago em 1973, a pesquisa comparativa sobre o uso de álcool etílico e Cannabis sp. apresenta um experimento natural clássico: uma única espécie (Homo sapiens), uma única substância (em cada caso) e uma grande diversidade de resultados em comportamento (Heath, 1987). Os dados epidemiológicos comparativos demonstram que as taxas de consumo variam entre os grupos estudados, indicando que não há uma única causa universal para seu abuso, e que as explicações para a variabilidade no consumo de cada substância devem ser procuradas nos contextos sociocultural e histórico particulares a cada grupo (Gordon, 1978; Menéndez, 1982). Estudos comparativos realizados nos Estados Unidos e na Austrália também atestam que os índios, de fato, nem sempre bebem mais, nem em estilos diversos dos da população regional (Kunitz G Levy, 1994; Saggers G Gray, 1998). Ademais, as taxas de consumo variam entre grupos pertencentes à mesma etnia, de acordo com idade, gênero ou religião (Kunitz, 2006).

Há poucos estudos epidemiológicos no Brasil comparando diferentes grupos populacionais (Albuquerque G Souza 1998; Bordignon apud Quiles, 2000), mas os dados existentes apoiam as conclusões dos estudos feitos em outras partes do mundo. Uma pesquisa usando o questionário Cage ${ }^{3}$ registrou uma taxa global de alcoolismo de 17,6\% entre os Terena, a qual corresponde a um índice cerca de $5 \%$ a $6 \%$ superior em relação à taxa estimada para brasileiros não índigenas (Albuquerque G Souza, 1998). Porém, entre os Terena, há variações de consumo dependentes do grupo religioso, da relação conjugal e do sexo. Para cada 24 homens terena, há apenas uma mulher diagnosticada como alcoólatra. ${ }^{4}$ Os autores sugerem que a baixa taxa de alcoolismo para as mulheres pode estar relacionada com a organização familiar e o exercício dos papéis designados para cada sexo. O estudo sobre os Bororo também registrou índices diferentes para homens e mulheres (Bordignon apud Quiles, 2000).

Tais pesquisas demonstram a necessidade de se investigar as causas que originam ou determinam o consumo abusivo de álcool em grupos específicos da população indígena, em vez de se definir a síndrome como um fenômeno universal/ biológico/individual.

\section{Contexto e comportamento}

A variação no processo de alcoolização entre os grupos se manifesta não só nas diferenças das taxas de consumo, mas também no comportamento 
(MacAndrew G Edgerton, 1969). Se o álcool libera as inibições e produz na pessoa outro estado de ânimo e consciência, o comportamento resultante dessa liberação varia de um grupo para outro porque expressa valores sociais diferentes em cada caso. É necessário considerar o contexto cultural e seus valores como fatores determinantes nas diferenças de estilos de beber e de agir quando se está embriagado.

Em uma pesquisa interdisciplinar conduzida por um antropólogo e um médico ao longo de 25 anos, nas décadas de 1960 a 1990, entre os Navajo dos Estados Unidos, foram identificados diferentes estilos de beber (Kunitz G Levy, 1994). Um deles, identificado como 'tradicional', tem sua origem associada à introdução de bebidas destiladas no século XX e se caracteriza por beber grandes quantidades, socialmente, em grupos masculinos, durante horas ou dias, até cair. Porém, entre essas bebedeiras episódicas, os mesmos homens passam dias ou semanas sem beber. $\mathrm{O}$ outro estilo, mais recente e percebido pelos próprios Navajo como problemático, envolve situações em que a pessoa costuma beber sozinha.

Em 1991, Kunitz e Levy aplicaram os critérios da terceira edição do Diagnostic and Statistical Manual of Mental Disorders (APA, 1987) aos dados obtidos em 1966 retrospectivamente, buscando identificar, depois de 25 anos, os participantes do estudo que apresentavam maior probabilidade de ter problemas em decorrência do consumo abusivo de álcool, tais como doenças, acidentes e morte. Entretanto, no estudo sobre os Navajo não se verificou essa correlação. Porém, a distinção entre os estilos de beber, isto é, o consumo social ou individual, mostrou-se mais útil para predizer quem apresentava maior risco. Assim, 80\% dos homens que bebiam socialmente em 1966 não bebiam mais em 1991. Muitos deles pararam espontaneamente sem tratamento médico. Os que continuavam a consumir bebidas alcoólicas bebiam em menor quantidade na segunda avaliação. Os valores ligados às responsabilidades familiares, à saúde, à religião e aos laços comunitários foram identificados como os fatores mais importantes para o controle do consumo. Os alcoolistas que bebiam sozinhos demonstraram menor probabilidade de conseguir parar ou moderar seu consumo, em 1991, e morriam mais frequentemente por causas relacionadas ao abuso de álcool (Kunitz $G$ Levy, 1994). ${ }^{5}$

A pesquisa sobre os Navajo é uma das poucas que acompanhou, durante um prazo longo, as vidas das pessoas diagnosticadas como dependentes, conforme a definição médica. Os autores levantaram vários fatores que influenciam o ato de beber e concluíram que o contexto é tão importante quanto os fatores biológicos e psicológicos. É necessário reconhecer a heterogeneidade dos estilos de beber, bem como as possibilidades de moderar ou parar de consumir bebidas alcoólicas.

Para refletir sobre essa heterogeneidade, os autores adotam o conceito de 'carreira' com o intuito de explicar os diferentes padrões de consumo ao longo do tempo (Kunitz G Levy, 1994; Kunitz, 2006). A pesquisa confirma os resultados de 
outros estudos e conclui que o alcoolismo não tem uma história natural. Ou seja, não é uma doença progressiva que irá terminar, necessariamente, em abstinência ou morte (Vaillant, 1999). Kunitz e Levy (1994: 39) utilizam o conceito de carreira para se referirem ao "comportamento sequencial de um indivíduo dentro de um papel social" (grifo meu) e contestam a visão clínica da síndrome que entende o alcoolismo como o desenvolvimento sequencial de processos biológicos. $\mathrm{O}$ aspecto social diz respeito ao contexto em que a pessoa aprendeu a beber e em que continua a beber, o que acarreta diferentes carreiras entre as pessoas que abusam do álcool.

A perspectiva antropológica enfatiza que é importante distinguir essas diversas carreiras e seus contextos a fim de identificar as possíveis causas e orientar o tratamento. $\mathrm{O}$ reconhecimento de que o comportamento é o resultado da interação entre a 'substância', a 'disposição psicológica' e o 'contexto', com ênfase no contexto, coincide com pesquisas feitas sobre o uso controlado de outras substâncias, como maconha, opiáceos e LSD. Zinberg (1984) argumenta que é importante considerar a interação desses três fatores - que ele chama drug, set e setting - e não sobrevalorizar os efeitos biológicos decorrentes da composição química das substâncias. O autor tem demonstrado que o consumo controlado de maconha e heroína depende largamente do contexto no qual o uso foi aprendido e dos contextos subsequentes em que tais substâncias estão presentes (MacRae, 1992). ${ }^{6}$

Assim, se queremos estabelecer programas de prevenção e tratamento para povos indígenas, é fundamental investigar as manifestações e os contextos particulares do abuso de álcool entre eles. Subentende-se, assim, o afastamento das abordagens que explicam o porquê determinada pessoa se torna alcoolista e outra não, tratando o consumo abusivo de álcool como uma síndrome universal ou como resultado de causas psicológicas. As taxas de consumo, o comportamento do bêbado e as principais causas de abuso de álcool representam fenômenos coletivos. Os estudos citados concluíram que o comportamento ligado à ingestão de bebidas alcoólicas é determinado pelo meio social, tornando necessária a exploração, nas pesquisas, dos valores culturais, do processo histórico, da atualidade sociopolítica do grupo e das situações nas quais se aprende a beber e se continua a beber (Singer, 1986; Singer et al., 1992; Dias, 2008; Ferreira, 2001b; Souza, 2009; Assis, 2007; Ghiggi Jr., 2010; Pena, 2005). ${ }^{7}$

\section{Contextos tradicionais}

A fabricação e o uso de bebidas fermentadas e substâncias psicoativas originaram-se da necessidade humana de ritualizar a vida social. Em geral, o uso tradicional destas substâncias está ligado à esfera sagrada e à cosmologia do grupo. Certos pesquisadores afirmam que seu uso é tão antigo quanto a existência dos ritos religiosos e, talvez, tenha tido um papel fundamental nas primeiras experiências de êxtase religioso (Wasson, 1961; La Barre, 1972). Muitos estudos enfatizam o 
uso positivo e coletivo de tais substâncias. Os ingredientes empregados, o modo de preparar e a maneira de tomar variam de um grupo étnico para outro. O tabaco é o mais empregado para fins rituais, mas existem muitas outras substâncias utilizadas, dependendo da região e do grupo estudado. As substâncias tendem a ser ingeridas em situações controladas, e esse modo de consumo ritual expressa a integração do grupo com sua concepção cosmológica do mundo. As razões para consumir, bem como os efeitos desejados e esperados são claramente definidos pelos participantes. Esses efeitos são estimulados e compartilhados por meio de várias técnicas rituais (Langdon, 1986, 1992).

O uso de bebidas fermentadas em rituais está documentado nas etnografias, com base em que é possível fazer certas generalizações sobre as práticas de povos indígenas que envolvem a ingestão de bebidas alcoólicas.

Em primeiro lugar, é importante reconhecer que as bebidas fermentadas integram a fábrica social dos povos indígenas e fazem parte das manifestações de sociabilidade inter e intragrupal. Entre os povos amazônicos, a rotina da vida cotidiana é suspensa pelos ritos e festas coletivas, nos quais as bebidas fermentadas estão ligadas ao sagrado, ao divertimento, à reciprocidade e, em certos casos, à política. Muitas festas são cíclicas, marcando épocas específicas do calendário anual, como a colheita de certas frutas, a mudança das estações etc.

Essas festas podem despender semanas de preparação e envolver a participação de outras comunidades, prolongando-se durante vários dias. A preparação e a ingestão de caiçuma, chicha ou outras bebidas semelhantes foi indispensável, no passado de certos povos indígenas, para facilitar a sociabilidade, as negociações de casamento e outras alianças entre as comunidades. Existem também festas que têm uma natureza mais espontânea, marcando momentos particulares, como uma boa caçada ou colheita, um empreendimento coletivo ou uma reunião familiar. Além de contribuir para a sociabilidade e o divertimento, as bebidas fermentadas são usadas em ritos que favorecem a expressão simbólica da própria sociedade, de sua manifestação ante o divino e da consciência coletiva. A análise comparativa demonstra que o consumo tradicional destas substâncias tem um papel construtivo (Douglas, 1987) e constitutivo do grupo.

Um exemplo do papel construtivo do álcool é o uso tradicional de chicha feita de mandioca, milho ou frutas fermentadas pelos Siona, um grupo tukano da Colômbia. Tradicionalmente, este grupo organiza festas para tomar chicha durante dois ou três dias contínuos, como parte de seus processos políticos e sociais. Entre eles, a chicha é consumida festivamente para criar consenso comunitário quando há divergências sobre certos assuntos, tal como a escolha de uma nova liderança, para construir relações amigáveis com outros grupos ou para realizar trabalhos e celebrações comunais. As reuniões são momentos alegres, divertidos, propícios à demonstração de capacidade para a oratória política e servem para reafirmar 
sentimentos coletivos e alianças. Apesar de um dos objetivos dessas festas ser embriagar-se mesmo, calcula-se o quanto se pode beber e a duração da festa pela quantidade de chicha preparada para o evento, que somente termina quando acaba a chicha e, então, as pessoas partem felizes para casa.

Outro exemplo é a festa do kiki realizada pelos Kaingang do sul do Brasil (Crépeau, 1997; Almeida, 1998). Até o início do século XX, este rito em homenagem aos mortos foi realizado em todas as aldeias Kaingang (Baldus, 1979). O kiki continuou ocorrendo na Terra Indígena Xapecó até 1996, como afirmação simbólica da identidade étnica e da organização social, marcando, por um lado, as relações recíprocas entre os vivos e os mortos e, por outro, as relações entre as duas metades que formam a sociedade kaingang. O rito liga o grupo ao ciclo anual da natureza, à sua mitologia e aos que faleceram desde o último kiki. Caracteriza-se por várias fases preparativas da bebida kiki, feita tradicionalmente de mel fermentado. Acendese, depois, uma fogueira por três noites seguidas, terminando com uma visita ao cemitério, onde cada metade do grupo reza sobre os túmulos dos mortos da outra metade. Na volta, a comunidade festeja bebendo até acabar o kiki. Todas as atividades são organizadas por grupos de parentesco, divididos em metades, Kamé e Kairu, cada uma com suas responsabilidades organizadas de maneira recíproca.

No decorrer do tempo, a cachaça foi incorporada em quase todas as atividades da festa do kiki e adicionada à bebida feita de mel, dando ao rito a aparência de uma grande bebedeira coletiva, conhecida localmente como a 'farra dos índios'. Para o observador que não entende o significado simbólico do rito, atingir um estado exagerado de embriaguez parece ser a razão central de sua realização. Porém, o caráter construtivo para o grupo social, a reafirmação de sua identidade étnica e das relações entre os grupos de parentesco, com os mortos e com a natureza, permanecem como a função principal para os índios.

Em resumo, os indígenas bebem por razões diversas. Como, quando e quanto bebem são aspectos característicos do estilo de beber adotado em cada grupo étnico. O consumo tradicional de bebidas fermentadas está não só associado a atividades construtivas para o grupo social, como também expressa sensações e valores particulares. Os índios aprendem a beber seguindo os valores e comportamentos manifestados por seu grupo.

Para muitos destes povos, contudo, os estilos de beber mudaram e o comportamento atual, em grande parte, já não se explica pelas especificidades culturais (Saggers G Gray, 1998). Antes do domínio das sociedades indígenas pela civilização de origem europeia, o uso das tradicionais bebidas fermentadas era marcado pelo controle e pelos limites socioculturais, o que já não ocorre na maior parte dos povos indígenas sul-americanos.

Os estudos sobre os Bororo (Quiles, 2000; Viertler, 2002), ${ }^{8}$ que exploram em profundidade as motivações e as mudanças no comportamento de beber, 
confirmam essa observação. Os Bororo costumavam preparar a chicha para ficarem alegres. O comportamento dos que bebem cachaça hoje, ao contrário, é caracterizado por agressão e violência física. Atualmente, os valores associados ao comportamento do bêbado são influenciados significativamente pela introdução das bebidas destiladas, pelo processo de pacificação e pela inserção do índio na sociedade envolvente. Souza, Deslandes e Garnelo (2010) argumentam que a violência manifestada pelos jovens emerge em situações nas quais, apesar de o modo de beber expressar os valores e o ethos do grupo, os mecanismos tradicionais de controle perderam a eficácia. ${ }^{9}$

\section{Bebidas destiladas na atualidade indígena}

Para entender os processos de beber nas comunidades indígenas, é importante ter clareza de como estamos conceituando o fenômeno do uso e abuso do álcool. É necessário deslocar o problema do campo físico/individual para o coletivo/social. Para isso, o conceito de alcoolização permite uma perspectiva mais abrangente, na qual se percebe o fenômeno como uma atividade social construída ao longo do tempo e da história do contato dos índios com o entorno social mais amplo.

Se historicamente o uso de bebidas alcoólicas contribuiu de maneira positiva para os povos indígenas, hoje seu consumo foge ao estilo tradicional. Os índios estão bebendo outras substâncias e o fazem, frequentemente, em novos contextos sociais. Estas mudanças trazem consequências altamente negativas para as comunidades, na forma de violência geral e familiar, desnutrição, danos à saúde das crianças - em casos de síndrome alcoólica fetal -, atropelamentos nas estradas etc. (Fernandes G Almeida, 2001; Souza, Oliveira G Kohatsu, 2003; Pena, 2005; Wiik, Almeida G Fernandes, 2009).

O uso atual de bebidas destiladas também traz consequências negativas para as relações externas ao grupo. Além dos problemas de ordem pública e judicial, decorrentes do abuso do álcool, cria-se uma imagem negativa para os povos indígenas, já que 'alcoólatra' é um adjetivo empregado pela sociedade brasileira para caracterizar o índio e justificar sua exclusão social. Há até aqueles que questionam os direitos indígenas e os programas sociais direcionados a esse segmento da população brasileira em virtude de tal caracterização, alegando que eles não merecem ser respeitados. Os próprios índios não ignoram essas acusações nem os estereótipos a seu respeito. Por exemplo, o discurso do cacique Verá Mirim, de Angra dos Reis, objetivando definir a identidade guarani-mbyá, ressalta sua consciência da estigmatização implícita na dicotomia índio/branco e o reconhecimento de que o índio é um ser subalterno no mundo dos brancos. Quanto ao consumo de bebida alcoólica, seu discurso mostrava preocupação em responder 
às acusações feitas pelos brancos, afirmando que "índio puro mesmo, Guarani, não bebe" (Litaiff, 1996: 145).

Ao usar o conceito de alcoolização em vez de alcoolismo, deslocamos a problemática da síndrome. Assim, evitamos o raciocínio de que o alcoolista é o culpado - seja por irresponsabilidade, seja por fraqueza mental ou biológica - e consideramos o campo político-histórico, procurando as soluções nas comunidades. É necessário construir programas de prevenção em parceria com os índios, buscando identificar com eles os fatores coletivos e específicos ao grupo que contribuem para a consumo excessivo de álcool. É necessário indagar sobre os fatores múltiplos que convergem para determinar o fenômeno coletivo de alcoolização entre os povos indígenas do Brasil. ${ }^{10}$

\section{Alcoolização e a situação do índio diante da sociedade envolvente}

É possível identificar algumas características gerais do processo de contato no Brasil que permitem um entendimento das possíveis raízes do consumo de álcool pelos índios. Esse processo tem-se caracterizado por diferentes formas de violência. Podemos citar as guerras contra os índios e as agressões físicas que continuam até o presente em certas regiões do país. No sul, a caça aos índios pelos bugreiros, promovida para favorecer a expansão dos colonos do século XIX, continuou até as primeiras décadas do século XX (Santos, 1987; Tommasino, 1998). Por meio de documentação fotográfica, Silvio Coelho dos Santos (1997) demonstra as injustiças cometidas contra os Xokleng no século XX, bem como a transformação das suas vidas. Outro exemplo, ainda mais trágico, é o extermínio dos Xetá, no Paraná, durante as décadas de 1950 e 1960 (Silva, 1998, 2003). Em ambos os casos, a violência se tornou ainda mais marcante com a introdução de novas doenças e o rapto sistemático das crianças que, às vezes, eram submetidas a uma situação de quase escravidão. Dessas, poucas chegaram à idade adulta.

O caso dos Xetá se destaca por se tratar de um genocídio total, levado a cabo em poucos anos e ocorrido há apenas cinquenta anos. Porém, a violência e as doenças que o grupo sofreu são características do processo de dominação em todo o Brasil. O papel fundamental das epidemias como um fator constituinte das relações de contato não deve ser subestimado. Sabemos que, com o primeiro contato com as doenças europeias, as comunidades indígenas perderam entre $50 \%$ e $70 \%$ de seus membros. As epidemias trazidas pelos brancos desempenharam um papel central na redução drástica da população indígena (Ribeiro, 1982). Também é importante reconhecer que esses fatores biológicos se combinaram com fatores sociais e políticos para terem resultados tão letais. 
As epidemias são normalmente tidas como o principal agente da depopulação indígena (...) aqui eram os índios que morriam: agentes patogênicos da varíola, do sarampo, da coqueluche, da catapora, do tifo, da difteria, da gripe, da peste bubônica, possivelmente a malária, provocaram no Novo Mundo o que Dobyns chamou de "um dos maiores cataclismos biológicos do mundo". No entanto, é importante enfatizar que a falta de imunidade, devido ao seu isolamento, da população aborígene, não basta para explicar a mortandade, mesmo quando ela foi de origem patogênica. Outros fatores, tanto ecológicos quanto sociais, tais como a altitude, o clima, a densidade de população e o relativo isolamento, pesaram decisivamente. Em suma, os microorganismos não incidiram num vácuo social e político, e sim num mundo socialmente ordenado. (Carneiro da Cunha, 1992: 12-13; grifos meus)

Carneiro da Cunha está se referindo particularmente à política dos missionários e órgãos oficiais de governo, que mantinha os indígenas vivendo em grupos de alta densidade populacional, o que favoreceu as epidemias.

É essencial considerar um outro aspecto da inter-relação entre o social e o biológico que determinou a mortandade provocada pelas epidemias, isto é, os impactos sociais e psicológicos desses desastres. A chegada repentina de uma epidemia resulta na incapacitação simultânea de quase todos os membros de uma sociedade, gerando uma situação de desespero e trazendo mudanças dramáticas e permanentes às formas de organização política, social e familiar. A redução da população Xokleng de Ibirama, de 400 para 106 pessoas em menos de vinte anos (Santos, 1997), é representativa da diminuição geral das comunidades indígenas causada pelas epidemias. Com a perda da maioria dos seus membros, os grupos de parentesco, a base da organização social, foram se desintegrando. Não somente indivíduos queridos morreram, mas integrantes da rede social sustentada por papéis sociais recíprocos desempenhados por seus membros. As mortes em massa deixaram brechas no tecido social, frequentemente sem possibilidade de recuperação (Ribeiro, 1956). Os sistemas tradicionais de liderança e de reciprocidade econômica e social desabaram, por isso os sobreviventes tiveram de criar novas formas de associação e relacionamento.

Perderam-se também certos conhecimentos e atividades rituais, centrais para a manutenção do grupo, nas situações em que somente as gerações mais novas sobreviveram, pois, em geral, os mais velhos é que são especialistas nos conhecimentos do grupo. Os Waimiri-Atroari perderam quase todos os adultos entre 1973 e 1983, quando dois terços de sua população foi dizimada. A maior parte dos sobreviventes tinha menos de 30 anos em 1991 (Espíndola, 1995). A morte dos mais velhos significa uma perda inestimável da sabedoria e do conhecimento tradicionais, pois os poucos pajés e outros especialistas rituais são encarregados não somente dos ritos de cura, mas também dos ritos sagrados que afirmam a identidade do grupo. 
Resumindo, é necessário reconhecer que, do contato entre povos indígenas e europeus, resultou uma série de acontecimentos que deixaram as sociedades indígenas enfraquecidas - em número, em organização social e em herança simbólica. Lembranças dessas catástrofes ainda fazem parte da memória dos índios, que contam versões diferentes da história oficial sobre os resultados do contato. Citando novamente os Xokleng de Santa Catarina, os sobreviventes lembram as epidemias e mortes que os afligiram como uma das características mais marcantes do contato. Igualmente, as narrativas siona sobre as epidemias, que devastaram $75 \%$ de sua população entre 1900 e 1925, lamentam a perda da liderança e sabedoria dos pajés, principalmente nos ritos que visavam à garantia de uma vida comunitária saudável.

Passamos a apresentar casos específicos sobre o contato de indígenas com festividades não indígenas, com a intenção de compreender como tais experiências afetam os padrões de comportamento. ${ }^{11}$ Para os Bororo, a embriaguez está ligada à força e à coragem, à sexualidade, à alegria e disposição, bem como à identidade étnica (Quiles, 2000). Os Guarani dizem que a bebida e a música sertaneja dos bailes de brancos que frequentam os fazem pensar em sexo (Ferreira, 2001b). O significado de beber decorre, em parte, dos usos tradicionais das bebidas fermentadas do grupo em questão: quando e quanto foi ingerido e para que fins.

Entretanto, como demonstram pesquisas recentes realizadas no Brasil, é necessário ir além da tradição cultural e reconhecer a violência que os povos indígenas vivenciaram e continuam vivenciando. A situação atual é resultado do passado colonial, o que dificulta colocar em prática seu modo de vida e ter uma vida saudável. A questão da saúde indígena vai além da definição de saúde no seu 'senso estrito' (UNI, 1988) e envolve o acesso pleno aos serviços de saúde, à educação e ao direito de manutenção da vida. É preciso garantir que, apesar de todas as mudanças socioeconômicas, os índios possam contar com alternativas de vida que lhes permitam sair da posição marginal em que se encontram na sociedade brasileira. Como cada povo indígena, além de sua especificidade cultural, tem também especificidades políticas, históricas e econômicas, é indispensável procurar soluções que reflitam tal diversidade.

Há outros aspectos do contato que fazem parte da história dos índios perante o Estado e que devem ser explorados. Quais as consequências da perda de territórios e do confinamento que inviabilizam as práticas tradicionais de subsistência? Qual é o impacto da política de tutela do índio na construção de sua identidade na sociedade pluriétnica, um regime no qual ele não é adulto nem criança, ou seja, um sujeito a ser protegido pelo Estado, mas sem os direitos plenos da cidadania? Que mecanismos de controle têm sido exercidos pelos brancos? Se a introdução de bebidas destiladas fez parte desses mecanismos de dominação e controle, como isso aconteceu em outros lugares do mundo (Singer, 1986) e entre os índios do Brasil (Quiles, 2000; Oliveira, 2001; Assis, 2007)? 
A inserção do índio na sociedade nacional também requer reflexão. Por exemplo, os índios do sul do Brasil se encontram em uma situação diferente em relação aos da região do Xingu ou da selva amazônica, pois vivem nas regiões mais ricas e desenvolvidas do país, caracterizadas por uma renda per capita maior e melhores serviços nas áreas de educação e saúde pública. Contudo, essa situação favorável não inclui os índios, que, em oposição, vivem em condições de pobreza, com diversos problemas de sobrevivência, saúde, educação etc. A situação dos Kaiowá-Guarani é uma das mais precárias no Brasil, resultante dos últimos cinquenta anos de redução territorial, desmatamento e vulnerabilidade (Almeida, 1988; Brand, 1997). O atual quadro epidemiológico dos índios da região se caracteriza não por doenças epidêmicas, comuns entre índios recém-contatados, mas por doenças carenciais e endêmicas. Esse dado não surpreende, tendo em vista a situação particular desses grupos de muita pobreza e desnutrição, apesar de viverem em uma das regiões mais ricas do país.

As doenças carenciais - desnutrição, parasitoses e alcoolismo - são todas indicadoras de necessidades básicas não contempladas, a saber, a garantia de subsistência, educação, saúde e tolerância com o seu modo de vida (Unesco, 1997). Os indígenas que vivem no sul, em meio a uma população de origem europeia que os estigmatiza, são acusados de alcoólatras, como parte da identidade deteriorada atribuída a eles pelos 'brancos'.

\section{Considerações para os programas de prevenção e controle do abuso de álcool}

Os fatores que determinam como, o que e quando beber são múltiplos. Mostramos até aqui que os mais importantes têm origem nos contextos em que a pessoa aprende e se acostuma a beber. Procuramos demonstrar, também, que a alcoolização é um fenômeno heterogêneo e não uma doença com manifestações e causas universais. O abuso de álcool por certos povos indígenas está relacionado ao processo de pacificação e à situação atual do índio diante da sociedade envolvente. O alcoolismo, em conjunto com outros estereótipos negativos, faz parte da identidade do índio segundo o consenso de muitos brancos. Como reduzir, então, os danos provocados pelo abuso de álcool entre os povos indígenas?

Sugerimos, em primeiro lugar, examinar nossos próprios preconceitos sobre alcoolismo, para que nosso trabalho sempre reflita o reconhecimento de que o modo de beber é produto do contexto social/político/histórico e não uma doença na qual o doente é culpável. Como propõem vários autores que têm pesquisado os modos de beber (Menéndez, 1982, 1998; Souza, Schweickardt G Garnelo, 2007; Acioli, 2002; Ghiggi Jr., 2010), é melhor usar o termo alcoolização para referir-se às manifestações do consumo de álcool, pois ele permite reconhecer que o fenômeno 
é consequência de questões culturais, econômicas e políticas, e não uma patologia universal.

O uso do termo alcoolismo tem consequências negativas para o tratamento, como demonstram Kunitz e Levy (1994: 40): "o processo de definir ou rotular a condição como doença tem implicações profundas para a pessoa que a vivencia e para o resultado dela" (Tradução da autora). Ao comparar as diferenças de valores e das reações comunitárias ao consumo de álcool entre os índios Hopi e Navajo, com as taxas das mortes desses dois grupos atribuídas à cirrose, os autores verificaram que as taxas dos Hopi estavam mais altas que as dos Navajo devido às atitudes negativas e repressivas que a sociedade Hopi exercita sobre os membros que bebem demais. Examinando a 'carreira' de outra doença, a da epilepsia, Kunitz e Levy demonstraram que a maneira dos Navajo rotularem a doença em crianças cria vários problemas sociais e médicos. Em contraste, os Pueblo tratam as crianças com epilepsia do modo mais normal possível, o que evita tais problemas, e faz com que elas se tornem mais independentes na adolescência (Kunitz G Levy, 1994).

No Brasil, Quiles (2000) observa que o uso do conceito de alcoolismo não foi produtivo nos programas de tratamento. Para os Bororo, estava associado a preconceito, culpa e identidade estigmatizada e, por isso, os participantes do programa se sentiam julgados pelas conotações negativas e patológicas do termo. As poucas pesquisas direcionadas aos profissionais da saúde que trabalham com indígenas demonstram que muitos desses profissionais expressam os julgamentos e preconceitos do senso comum sobre alcoolismo (Conceição, 2007; Melo, Maciel G Neves, 2009; Figueiredo, 2000). Como afirmam Kunitz e Levy (1994), o conceito de alcoolismo como doença já esgotou seu valor no tratamento do abuso de álcool.

Em segundo lugar, para minimizar os problemas resultantes do consumo abusivo de álcool, é necessário que qualquer programa seja capaz de identificar os diferentes estilos de beber entre os grupos da comunidade, bem como os diversos contextos em que se aprende a beber. Deve-se indagar quais são os valores associados aos diferentes estilos de beber e às possíveis funções, negativas e positivas, que essas práticas têm para os grupos. Pesquisas de redes sociais e estudos longitudinais dirigidos examinando certas famílias podem ajudar a revelar as diferenças entre grupos e estilos de beber. Não podemos esquecer que a comunicação com a comunidade e a colaboração dos próprios índios para obter tais informações é imprescindível. Os índios têm percepções únicas sobre o fenômeno (Souza, Oliveira G Kohatsu, 2001; Souza, 2004, 2009; Benite, Taukane G Rodrigues, 2001) e muitos, como os Guarani (Ferreira, 2001a), também dispõem de estratégias tradicionais positivas que devem ser incorporadas e/ou estimuladas pelos programas de redução de consumo de bebidas alcoólicas. 
Assim, a estratégia principal é trabalhar com as sociedades envolvidas, questionando seus membros sobre o significado das bebidas alcoólicas na tradição cultural, bem como sobre as mudanças percebidas no momento atual. É essencial identificar suas preocupações e possíveis respostas aos problemas. Os programas de tratamento devem ser orientados para a educação e prevenção nos grupos com problemas específicos do abuso de álcool, tais como as mulheres e os adolescentes.

É fundamental, também, dar-se conta das lacunas quanto à informação que os membros das comunidades têm sobre as consequências de abuso de álcool. Os Navajo, por exemplo, apesar de se mostrarem bastante preocupados com o alto consumo de álcool, não estavam conscientes de todos os problemas que tal abuso poderia acarretar para suas famílias e para o grupo como um todo. A educação orientada à comunidade sobre suas consequências negativas teve, por isso, resultados positivos (Kunitz G Levy, 1994).

De acordo com o estudo de Kunitz e Levy, que acompanhou o processo de alcoolização navajo ao longo de 25 anos, os programas de prevenção que incluem a comunidade comprovaram ser mais eficazes do que os programas desenvolvidos anteriormente, que se concentraram no tratamento individual com a internação esporádica. Esses programas culpabilizaram as vítimas e ignoraram os efeitos do consumo abusivo na psicologia do alcoolista e da sua família.

No final da década de 1970, o enfoque dos programas de tratamento mudou para prevenção e educação nos grupos identificados como problemáticos devido aos seus estilos de beber, incluindo mulheres e adolescentes. Kunitz e Levy observaram que o comportamento alcoolista dos Navajo tinha melhorado em 1991, possivelmente, em função dos novos programas. Os autores citam o aumento da participação da comunidade como um aspecto positivo. Os novos programas estimularam a preservação das terapias indígenas tradicionais e as mudanças na conceitualização do alcoolismo, entre os Navajo, de doença para um fenômeno de comportamento. Os autores observaram que os programas de prevenção têm funções latentes que devem ter contribuído também para melhorar as relações do grupo, gerando novos empregos, um novo senso de 'empoderamento' (empowerment), a preservação do conhecimento religioso e um sentido de identidade cultural.

A equipe, formada por membros da Fundação Nacional de Saúde e uma antropóloga da Universidade Federal do Rio Grande do Sul, que realizou um projeto de intervenção entre 2000 e 2004 com os Guarani do Rio Grande de Sul, observou que a discussão sobre o abuso de bebidas alcoólicas parece ter estimulado efeitos positivos no grupo, justamente por causa da inclusão das lideranças e pajés no entendimento do problema (Ferreira, 2004a, 2004b).

A prevenção do abuso de álcool é uma questão de educação e saúde comunitária e deve, portanto, se basear nas necessidades de cada comunidade e ter sua participação em todas as fases de implementação de programas. Estes 
devem estar ligados às opções e alternativas de vida do grupo no contexto atual. Assim, as possíveis soluções para a prevenção do problema devem-se voltar para a construção de formas de bem-estar social sustentáveis, com a afirmação de identidade positiva, e não somente para atividades diretamente orientadas à questão da síndrome de dependência nos indivíduos. Se o abuso de álcool é o resultado de vários fatores indiretos, as soluções para a sua prevenção terão de lidar com esses fatores, o que pode levar a resultados diretos, culminando na diminuição do consumo de bebidas alcoólicas, tanto quanto indiretos, ou seja, repercutir positivamente em outros âmbitos das relações sociais.

\section{Notas}

1 Este capítulo é uma versão revisada de: Langdon, E. J. M. O abuso de álcool entre os povos indígenas no Brasil: uma avaliação comparativa. Tellus, 5(8/9): 103-127, 2005. Texto republicado com autorização da autora e do editor da revista.

2 A maior parte das considerações sobre os fatores contextuais e os programas de prevenção discutidos aqui se aplicam também ao abuso de outras drogas.

3 O questionário Cage é usado como um instrumento para identificar possíveis alcoolistas ou indivíduos em situação de risco. Consiste de quatro perguntas sobre o uso de bebida alcóolica consumida nos últimos 12 meses. Ver Souza, Schweickardt e Garnelo (2007).

4 Ver Souza, Schweickardt e Garnelo (2007) sobre as limitações do diagnóstico de dependência pelo instrumento Cage utilizado para a pesquisa.

5 Em pesquisa sobre os Bororo, Quiles (2000) descreve o mesmo fenômeno de ingestão de bebida alcoólica em episódios intermitentes, sem criar dependência física.

6 Ver Gilberto Velho (1998) para o uso social de maconha, LSD e cocaína entre grupos de classe média brasileira.

$7 \quad$ Ver também capítulo 8 deste livro.

8 Ver também o capítulo 3 deste livro.

9 Ver também capítulo 4 deste livro.

10 Veja Benite e colaboradores (2001) para uma análise nativa das causas sociais, econômicas e históricas da introdução e do consumo abusivo das bebidas destiladas entre os índios hoje.

11 Veja Calavia Sáez (2004) para uma reflexão sobre a incorporação de cachaça em festas relacionadas aos contextos de contato. 
Referências

ACIOLI, M. D. O Processo de Alcoolização entre os Pankararu: um estudo em etnoepidemiologia, 2002. Tese de Doutorado, Campinas: Universidade de Campinas.

ALBUQUERQUE, J. I. A. G SOUZA, J. A. Prevalência do alcoolismo na população indígena da Nação Terena do Complexo Sidrolândia - Colônia dos Irmãos do Buruti. OFICINA MACRORREGIONAL DE ESTRATÉGIA, PREVENÇÃO E CONTROLE DAS DST/AIDS PARA AS POPULAÇÕES INDÍGENAS DAS REGIÕES SUL E SUDESTE, E DO MATO GROSSO DO SUL, 1, 1998, Londrina. Anais... Coordenação Nacional de DST/Aids/ Programa Municipal para DST/Aids/Alia, 1998.

ALMEIDA, L. K. Dinâmica Religiosa entre os Kaingang do Posto Indígena de Xapecó, 1998. Dissertação de Mestrado, Florianópolis: Universidade Federal de Santa Catarina.

ALMEIDA, R. T. Breves comentários sobre saúde e relações de contato: os Guarani brasileiros. Saúde em Debate: 28-32, 1988.

AMERICAN PSYCHIATRIC ASSOCIATION (APA). Diagnostic and Statistical Manual of Mental Disorders (DSM-III-R). Washington, D.C.: American Psychiatric Association, 1987.

ASSIS, L. P. S. Da cachaça à libertação: mudanças nos hábitos de beber do Povo Dâw no Alto Rio Negro. Antropos, 1(1): 101-173, 2007.

BALDUS, H. O culto aos mortos entre os Kaingang de Palmas. In: BALDUS, H. Ensaios de Etnologia Brasileira [1937]. São Paulo: Companhia Editora Nacional, 1979.

BENITE, A. D. Y.; TAUKANE, G. M. G RODRIGUES G. M. As narrativas de representantes indígenas sobre o uso de bebidas alcoólicas dentro das áreas indígenas. In: SEMINÁRIO SOBRE ALCOOLISMO E DST/AIDS ENTRE OS POVOS INDÍGENAS, 4 (Série Seminários e Congressos). Brasília: Ministério da Saúde, Coordenação Nacional de DST e Aids, 2001.

BRAND, A. O Impacto da Perda da Terra Sobre a Tradição Kaiowá/Guarani: os difíceis caminhos da palavra, 1997. Tese de Doutorado, Porto Alegre: Pontifícia Universidade Católica do Rio Grande do Sul.

CALAVIA SAÉZ, O. In search of ritual: tradition, outer world and bad manners in the Amazon. Journal of the Royal Anthropological Institute Man, 10(1): 157-173, 2004.

CARNEIRO DA CUNHA, M. História dos Índios no Brasil. São Paulo: Fapesp, Companhia das Letras, SMC, 1992.

CONCEIÇÃO, J. J. A Percepção dos Profissionais de Saúde da Área Indígena Potiguara sobre o Consumo de Bebidas Alcoólicas pelos Índios, 2007. Monografia de Especialização, João Pessoa: Universidade Federal da Paraíba.

CRÉPEAU, R. Mito e ritual entre os índios Kaingang do Brasil Meridional. Horizontes Antropológicos, 3(6): 173-186, 1997.

DIAS, L. F. Usos e abusos de bebidas alcoólicas segundo os povos indígenas do Uaçá. In: LABATE, B. C. et al. (Orgs.). Drogas e Cultura: novas perspectivas. Salvador: EDUFBA/ Ministério da Cultura, 2008. 
DOUGLAS, M. A Distinctive Anthropological Perspective: constructive drinking perspectives on drink from anthropology. Cambridge: Cambridge University Press, 1987.

ERTHAL, R. M. C. O Suicídio Ticuna na Região do Alto Solimões - AM, 1998. Tese de Doutorado, Rio de Janeiro: Ensp/Fiocruz.

ESPÍNDOLA, C. V. Medicina Indígena Waimiri-Atroari: representações e práticas, 1995. Dissertação de Mestrado, Florianópolis: Universidade Federal de Santa Catarina.

EVERETT, M.; WADDELL, J. O. G HEATH, D. B. (Orgs.). Cross-Cultural Approaches to the Study of Alcohol: an interdisciplinary perspective. The Hague: Mouton, 1976.

FERNANDES, R. C. G ALMEIDA, L. K. Diagnóstico Antropológico sobre o Alcoolismo entre os Kaingang das Terras Indígenas Votouro, Rio da Várzea, Ligeiro, Monte Caseros e Cacique Doble. Porto Alegre: Funasa, 2001. Relatório. (Mimeo.)

FERREIRA, L. O. Mba'e Achÿ: a concepção cosmológica da doença entre os Mbyá-Guarani num contexto de relações interétnicas - RS, 2001a. Dissertação de Mestrado, Porto Alegre: Universidade Federal do Rio Grande do Sul.

FERREIRA, L. O. O Impacto do uso abusivo de bebidas alcoólicas. Tellus, 4(2): 39-64, 2001b.

FERREIRA, L. O. As "boas palavras" dos Xondaro Marãogatu como alternativa para a redução do consumo de bebidas alcoólicas entre os Mbyá-Guarani - RS. Tellus, 4(7): 121-136, 2004a.

FERREIRA, L. O. O "fazer antropológico" em ações voltadas para a redução do uso abusivo de bebidas alcoólicas entre os Mbyá-Guarani, no Rio Grande do Sul. In: LANGDON, E. J. G GARNELO, L. (Orgs.). Saúde dos Povos Indígenas: reflexões sobre antropologia participativa. Rio de Janeiro: Contra Capa, ABA, 2004b.

FIGUEIREDO, V. Issues of Health and Marginality in Northern Brazil, 2000. Master's dissertation, Londres: Goldsmith University.

GHIGGI JR., A. Estudo Etnográfico sobre Alcoolização entre os Índios Kaingang da Terra Indígena Xapecó: das dimensões construtivas à perturbação, 2010. Dissertação de Mestrado, Florianópolis: Universidade Federal de Santa Catarina.

GORDON, A. J. Ethnicity and alcohol use. Medical Anthropology Quarterly, 2(4), 1978. (Special issue)

HEATH, D. B. Anthropology and alcohol studies: current issues. Annual Reviews of Anthropology, 16: 99-120, 1987.

KUNITZ, S. J. Life-course observations of alcohol use among Navajo Indians: natural history or careers. Medical Anthropology Quarterly, 20(3): 279-296, 2006.

KUNITZ, S. J. G LEVY, J. E. Drinking Careers: a twenty-five-year study of three Navajo populations. New Haven: Yale University Press, 1994.

LA BARRE, W. Hallucinogens and the shamanic origins of religion. In: FURST, P. (Ed.). Flesh of the Gods: the ritual use of hallucinogens. New York: Praeger Publishers, 1972. 
LANGDON, E. J. Las clasificaciones del yagé dentro del grupo Siona: etnobotánica, etnoquímica e historia. América Indígena, XLVI (1): 101-116, 1986.

LANGDON, E. J. A cultura siona e a experiência alucinógena. In: VIDAL, L. (Org.). Grafismo Indígena: estudos de antropologia estética. São Paulo: Nobel, 1992.

LITAIFF, A. As Divinas Palavras: identidade étnica dos Guarani-Mbyá. Florianópolis: Editora da Universidade Federal de Santa Catarina, 1996.

MACANDREW, C. G EDGERTON, R. B. Drunken Comportment: a social explanation. Chicago: Aldine, 1969.

MACRAE, E. Guiado pela Lua. Rio de Janeiro: Brasiliense, 1992.

MANDELBAUM, D. G. Alcohol and Culture. Current Anthropology, 6(3): 281-293, 1965.

MELO, J. R. F. M.; MACIEL, S. C. G NEVES, F. S. Representação social sobre o uso do álcool na população indígena potiguara: um estudo com profissionais de saúde do sexo feminino. In: SEMINÁRIO NACIONAL SOBRE GÊNERO E PRÁTICAS SOCIAIS, II. João Pessoa: UFPB, 2009.

MENÉNDEZ, E. L. El proceso de alcoholización: revisión crítica de la producción socioantropológica, histórica y biomédica en América Latina. Revista Centroamericana de Ciencias de la Salud, 22: 61-94, 1982.

MENÉNDEZ, E. L. Antropologia médica e epidemiologia: processo de convergência ou processo de medicalização? In: ALVES, P. C. G RABELO, M. C. (Orgs.). Antropologia da Saúde: traçando identidade e explorando fronteiras. Rio de Janeiro: Editora Fiocruz, Relume Dumará, 1998.

OLIVEIRA, M. C. Alcoolismo entre os Kaingang do sagrado e lúdico à dependência. In: SEMINÁRIO SOBRE ALCOOLISMO E DST/AIDS ENTRE OS POVOS INDÍGENAS, 4 (Série Seminários e Congressos). Brasília: Ministério da Saúde, Coordenação Nacional de DST e Aids, 2001.

PENA, J. L. Os índios Maxakali: a propósito do consumo de bebidas de alto teor alcoólico. Revista de Estudos e Pesquisas, 2(2): 99-121, 2005.

QUILES, M. I. Mansidão de Fogo: um estudo etnopsicológico do comportamento alcoólico entre os índios Bororo de Meruri, Mato Grosso, 2000. Dissertação de Mestrado, Cuiabá: Universidade Federal de Mato Grosso.

RIBEIRO, D. Convívio e contaminação: efeitos dissociativos da depopulação provocada por epidemias em grupos indígenas. Sociologia, 18: 3-50, 1956.

RIBEIRO, D. Os Índios e a Civilização. Rio de Janeiro: Vozes, 1982.

SAGGERS, S. G GRAY, D. Dealing with Alcohol: indigenous usage in Australia, New Zealand and Canada. Cambridge: Cambridge University Press, 1998.

SANTOS, S. C. Índios e Brancos no Sul do Brasil: a dramática experiência dos Xokleng. 2.ed. Porto Alegre: Movimento, 1987.

SANTOS, S. C. Os Índios Xokleng: memória visual. Florianópolis: Editora da Universidade Federal de Santa Catarina/Univali, 1997. 
SILVA, C. L. Sobreviventes do Extermínio: uma etnografia das narrativas e lembranças da sociedade Xetá, 1998. Dissertação de Mestrado, Florianópolis: Universidade Federal de Santa Catarina.

SILVA, C. L. Em Busca da Sociedade Perdida: o trabalho de memória Xetá das narrativas de seus sobrevivientes, 2003. Tese de Doutorado, Brasília: Universidade de Brasília.

SIMONIAN, L. T. L. Alcoolismo entre indígenas: abordagens, contextos e perspectivas. In: OFICINA MACRORREGIONAL DE ESTRATÉGIA, PREVENÇÃO E CONTROLE DAS DST/AIDS PARA AS POPULAÇÕES INDÍGENAS DAS REGIÕES SUL E SUDESTE, E DO MATO GROSSO DO SUL, 1, 1998, Londrina. Anais... Coordenação Nacional de DST/Aids/Programa Municipal para DST/Aids/Alia, 1998.

SINGER, M. Toward a political-economy of alcoholism: the missing link in the anthropology of drinking. Social Science and Medicine, 23: 113-130, 1986.

SINGER, M. et al. Why does Juan García have a drinking problem? The perspective of critical medical anthropology. Medical Anthropology, 14(1): 77-108, 1992.

SOUZA, J. A; OLIVEIRA, M. G KOHATSU, M. Diretrizes para Abordagem do Alcoolismo em Populações Indígenas. Londrina: Secretaria de Ação Social, Prefeitura Municipal de Londrina, 2001.

SOUZA, J. A; OLIVEIRA, M. G KOHATSU, M. O uso de bebidas alcoólicas nas sociedades indígenas: algumas reflexões sobre os Kaingang da bacia do rio Tibagi, Paraná. In: COIMBRA, C.; SANTOS, R. G ESCOBAR, A. L. (Orgs.). Epidemiologia e Saúde dos Povos Indígenas do Brasil. Rio de Janeiro: Editora Fiocruz, 2003.

SOUZA, M. L. P. Alcoolização e Violência no Alto Rio Negro, 2004. Dissertação de Mestrado, Manaus: Universidade Federal do Amazonas.

SOUZA, M. L. P. Juventude, Uso de Álcool e Violência em um Contexto Indígena em Transformação, 2009. Tese de Doutorado, Rio de Janeiro: Instituto Fernandes Figueira/Fiocruz.

SOUZA, M. L. P. G GARNELO, L. Desconstruindo o alcoolismo: notas a partir da construção do objeto de pesquisa no contexto indígena. Revista Latinoamericana de Psicopatologia Fundamental, IX (2): 279-292, 2006.

SOUZA, M. L. P.; SCHWEICKARDT, J. C. G GARNELO, L. O processo de alcoolização em populações indígenas no Alto Rio Negro: limitações do Cage como instrumento de screening para dependência ao álcool. Revista Psiquiatria Cliníca, 34(2): 90-96, 2007.

SOUZA, M. L. P.; DESLANDES, S. F. G GARNELO, L. Modos de vida e modos de beber de jovens indígenas em um contexto de transformações. Ciência G Saúde Coletiva, 15(3): 709-716, 2010.

TOMMASINO, K. A. Experiência histórica dos índios do sul do Brasil: expropriação e violência na situação de contato. In: OFICINA MACRORREGIONAL DE ESTRATÉGIA, PREVENÇÃO E CONTROLE DAS DST/AIDS PARA AS POPULAÇÕES INDÍGENAS DAS REGIÕES SUL E SUDESTE, E DO MATO GROSSO DO SUL, 1, 1998, Londrina. Anais... Coordenação Nacional de DST/Aids/Programa Municipal para DST/Aids/Alia, 1998.

UNESCO. Princípios sobre a Tolerância. São Paulo: USP/FFLCH, 1997. 
UNIÃO DAS NAÇÕES INDÍGENAS (UNI). Os povos indígenas e o direito à saúde. Saúde em Debate: 8-9, 1988.

VAIllant, G. E. A História Natural do Alcoolismo Revisitada. Porto Alegre: Artes Médicas, 1999.

VELHO, G. Nobres e Anjos: um estudo de tóxicos e hierarquia. Rio de Janeiro: Fundação Getúlio Vargas, 1998.

VIERTLER, R. B. Convívio interétnico e alcoolismo entre os Bororo: resultados de uma pesquisa. Tellus, 2(2): 9-38, 2002.

WASSON, R. G. The hallucinogenic fungi of Mexico: an inquiry into the origin of religious ideas among primitive peoples. Botanical Museum Leaflets, Harvard University, XIX (7) : 137-162, 1961.

WIIK, F. B.; ALMEIDA, L. K. G FERNANDES, R. O consumo de bebidas alcoólicas entre os Kaingang do Rio Grande do Sul. In: SILVA, G. F.; PENNA, R. G CARNEIRO, L. C. C. (Orgs.). RS Índio: cartografias sobre a produção do conhecimento. Porto Alegre: EDIPUCRS, 2009.

ZINBERG, N. Drug, Set, and Setting: the basis for controlled intoxicant use. New Haven: Yale University Press, 1984. 


\section{Cauinagens e Bebedeiras: \\ os índios e o álcool na história do Brasil $^{1}$}

João Azevedo Fernandes

Trouxeram-lhes vinho numa taça; mal the puseram na boca; não gostaram nada, nem quiseram mais. ${ }^{2}$

\section{O impacto do álcool nas sociedades indígenas}

Um dos aspectos mais interessantes e menos estudados do chamado 'contato' interétnico é o lugar ocupado neste processo pelas bebidas alcoólicas, especialmente no que se refere ao seu impacto nas sociedades indígenas colhidas pelo expansionismo ocidental. A partir de uma forma de utilização eminentemente ritual, fortemente relacionada às atividades xamanísticas e ao papel social e metafísico das mulheres, as bebidas alcoólicas assumiram com a chegada dos europeus uma dimensão que, em muitos casos, mostrou-se catastrófica e desagregadora para as sociedades indígenas, servindo mesmo, por vezes, como uma arma conscientemente utilizada pelos agentes do colonialismo.

Não se tentará, contudo, realizar aqui uma análise que apresente os indígenas como meras 'vítimas' do colonialismo europeu: as sociedades indígenas possuíam dinâmicas próprias e suficientemente autônomas para determinar, em grande medida, as formas particulares segundo as quais eram absorvidas as alterações da experiência etílica resultantes do contato. Tentar-se-á demonstrar que o estudo da experiência etílica nas sociedades ameríndias pode se constituir em um instrumento privilegiado para uma maior compreensão do contato interétnico como um todo, em uma visão que incorpore os índios e suas culturas como agentes ativos deste processo.

Em 18 de novembro de 1998, a revista IstoÉ publicava uma reportagem sobre os índios Maxacali de Minas Gerais (Abdala, 1998). Nas palavras da repórter,

Os Maxakalis foram perseguidos, suas terras invadidas, mas conseguiram resistir a quase tudo o que vinha do homem branco. Quase tudo. Eles caíram numa 
armadilha comum entre os ditos civilizados: pegaram gosto pelo álcool e hoje vivem uma tragédia que ameaça o futuro da tribo. Noventa por cento deles são alcoólatras. Essa estatística não se restringe à população adulta. Crianças de oito e nove anos já bebem como gente grande. Quando falta a cachaça, os índios tomam qualquer coisa: perfume, desodorante, éter. O álcool virou artigo de luxo na aldeia, abrindo espaço para os comerciantes das cidades vizinhas manipularem os costumes da tribo.

Mais do que simplesmente destruir a saúde dos Maxacali, provocando mortes por coma alcoólico e outras causas (índios morreram por insolação ao ficarem jogados durante horas em sarjetas, por exemplo), o álcool é responsável pela desagregação social do grupo, ao provocar brigas e mortes:

ISTOÉ presenciou uma briga do cacique Pimenta com sua mulher. Ambos estavam embriagados. Irritados, os índios não aceitam nenhuma aproximação nessa hora. 'O negócio é tão feio que quando eles estão brigando eu nem chego perto. Fico trancado aqui e só saio quando me chamam para socorrer um deles', contou o técnico de enfermagem da Funai que mora dentro da Aldeia Pradinho, Carlos Alberto Pereira da Silva. (Abdala, 1998)

A relação dos Maxacali com a cachaça começou nos anos 1920, quando os fazendeiros trocavam trabalho pela bebida. Segundo Maria Hilda Paraíso, antropóloga da Universidade Federal da Bahia ouvida pela jornalista, os fazendeiros "gostavam de dar bebida ao índio para vê-lo bêbado e rir à sua custa" (Abdala, 1998). Os comerciantes se aproveitam dos índios, vendendo-lhes um litro de álcool puro por $\mathrm{R} \$ 10,00$ ou trocando $80 \mathrm{~kg}$ de feijão por uma garrafa de cachaça. De acordo com a reportagem, os índios "sabem que estão fazendo algo de errado e negam de pés juntos que sejam viciados. 'Pequi não gosta de caiboca [cachaça]. Nunca bebe' (sic), repetia o índio Pequi, que exalava álcool e mal conseguia ficar em pé".

A situação vivida pelos Maxacali em fins do século XX repete-se em várias outras partes do Brasil e do mundo, e repetiu-se por inumeráveis vezes na história das relações entre as sociedades ocidentais e aquelas ditas 'primitivas'. Essas relações nem sempre foram marcadas pelos massacres e pela dizimação, como quer uma posição tão politicamente correta quanto historicamente equivocada (Carneiro da Cunha, 1992).

$\mathrm{Na}$ verdade, os europeus souberam se imiscuir nas estruturas sociais e culturais nativas e utilizar a universal busca humana pelas substâncias psicoativas em função de suas próprias ações de conquista, realizando a operação que Stephen Greenblatt chama de "improvisação de poder": "a habilidade europeia de insinuarse várias vezes dentro das estruturas políticas, religiosas e também psíquicas preexistentes dos nativos e utilizá-las em proveito próprio" (apud Giucci, 1992: 207). 
No que diz respeito à historiografia, é crucial procurar entender a importância das práticas etílicas e suas transformações, durante o processo de contato e de colonização. Os historiadores brasileiros não mais se contentam com a simples denúncia do impacto destrutivo da conquista europeia sobre as sociedades ameríndias, mas também buscam estabelecer as diferentes formas dessa conquista. É cada vez mais necessário o estudo das instâncias, sociais e simbólicas, pelas quais as sociedades indígenas influenciaram as sociedades europeias e a nascente sociedade brasileira (Monteiro, 1994; Raminelli, 1994; Vainfas, 1995; Almeida, 2003; Fernandes, 2003; Pompa, 2003).

\section{A colonização e as bebidas alcoólicas}

Os relatos de cronistas e viajantes são ricos em referências a fatos semelhantes aos descritos na reportagem sobre os Maxacali: o gosto pela bebida, por exemplo, é comentado por Alexandre Rodrigues Ferreira, que em 1787 escrevia que, "sendo eles [os índios] naturalmente homens tristes e pensativos, não carece que bebam, mas basta a simples esperança de beberem para logo transbordar em seus rostos a alegria, a esperteza, a vivacidade" (Ferreira, 1974: 45-46).

Os naturalistas Spix e Martius, em princípios do século XIX, trocaram, por cachaça, favores, serviços e proteção com os índios durante toda a sua viagem. Ao final, com o decréscimo do estoque, essa colaboração praticamente desapareceu:

[nos abandonaram] um após outro, todos os índios que eram domiciliados no Alto Japurá ou nos seus afluentes, e que nos haviam sido emprestados pelos diversos tubixabas, para caçadores e remadores. Assim se foi reduzindo a guarnição, em cada parada, e muitas noites víamos um ou outro, sem esperar pelo pagamento, tomar os seus poucos haveres e desaparecer, de manso, do acampamento para o mato, e não voltar mais. Cachaça, a poderosa panaceia para todas as disposições de ânimo do índio, não tínhamos mais bastante para conservá-los perto de nós. (Spix G Martius, 1976, v.III: 227)

São comuns também os relatos de conflitos, advindos do uso de bebidas alcoólicas, no interior das sociedades nativas. Tais conflitos podiam, vez por outra, se tornar ameaçadores para os europeus. O vianês Afonso Gonçalves, um dos primeiros povoadores de Pernambuco, trouxe de Portugal para a vila de Igaraçu uma grande quantidade de parentes e conterrâneos, que passaram a produzir mantimentos e cana-de-açúcar, em meio a relações aparentemente amistosas com os nativos: "e em tudo os ajudavam os gentios que estavam de paz, e entravam e saíam da vila, com seus resgates ou sem eles, cada vez que queriam" (Salvador, 1975: 115). 
Não obstante, essas relações podiam revelar-se bastante instáveis:

Mas, embebedando-se uma vez, uns poucos se começaram a ferir e matar, de modo que foi necessário mandar o capitão alguns brancos com seus escravos que os apartassem, ainda que contra o parecer dos nossos línguas e intérpretes, que lhe disseram os deixasse brigar e quebrar as cabeças uns aos outros, porque, se lhe acudiam, como sempre se receiam dos brancos, haviam cuidar que os iam prender e cativar, e se haviam de pôr em resistência. E assim foi, que logo se fizeram em um corpo e com a mesma fúria que uns traziam contra os outros se tornaram todos aos nossos, sem bastar vir depois o mesmo capitão com mais gente para os acabar de aquietar. (Salvador, 1975: 115-116)

Tais conflitos também podiam ser manipulados em função dos interesses dos conquistadores. Jerônimo de Albuquerque, governando Pernambuco na ausência de Duarte Coelho, utilizou-se do amor às cauinagens para fazer com que os próprios índios Caeté acusassem alguns dentre eles por terem matado e comido uns portugueses e seus escravos. Aconselhado por Vasco Fernandes de Lucena, homem de enorme prestígio entre os nativos, Albuquerque,

mandou fazer vinhos e, eles feitos, mandou chamar os principais das aldeias dos gentios e, tanto que vieram, os mandou agasalhar pelos línguas ou intérpretes, que o fizeram ao seu modo, bebendo com eles, porque não suspeitassem ter o vinho peçonha e o bebessem de boa vontade. (Salvador, 1975: 120)

Estando os índios já embriagados, Lucena discursou de forma habilidosa, convidando-os a fazer guerra contra os Tabajara, deixando claro, porém, que deveriam nomear os responsáveis pelas mortes de portugueses e escravos índios, já que os culpados poderiam atacar suas casas e famílias enquanto estivessem na guerra:

E, como eles (deve ser pela virtude do vinho, que entre outras tem também esta) nunca falam a verdade senão quando estão bêbados, começaram a nomear os culpados, e sobre isto vieram às pancadas e frechadas, ferindo-se uns aos outros, até que acudiu o governador Jerônimo de Albuquerque e os prendeu e, depois de averiguar quais foram os homicidas dos brancos, uns mandou pôr em bocas de bombardas e dispará-las à vista dos mais, para que os vissem voar feitos pedaços, e outros entregou aos acusadores que os mataram em terreiro e os comeram em confirmação da sua inimizade (...). (Salvador, 1975: 121)

Tais relatos, nada incomuns nas fontes, mostram-nos a pertinência da estratégia de pesquisa proposta aqui, qual seja a de estudar o contato interétnico por meio da experiência etílica das sociedades indígenas. Essa experiência foi forte o suficiente para influenciar a própria sociedade colonial: Sérgio Buarque de Holanda, em Caminhos e Fronteiras, obra publicada em 1956, antecipa uma 
preocupação mais profunda dos historiadores com o contato interétnico. O autor trata de várias beberagens mamelucas e caipiras que herdaram não apenas materiais e processos de fabricação, mas também formas marcadamente indígenas de construção social da experiência etílica. Exemplo notável é o da catimpuera, uma bebida fermentada de milho:

Em Minas seu fabrico era competência de mulheres, que mascavam o milho de canjica, lançando-o depois no caldo da mesma canjica: já no dia seguinte tinha seu azedo e estava perfeita. Diz o informante anônimo que, para ser mais saborosa, deveria ser mascada por alguma velha, e quanto mais velha melhor. (Holanda, 1994: 184)

Nota-se aqui claramente a sobrevivência, no mundo pós-contato, do tradicional papel feminino no preparo das bebidas fermentadas, embora com uma curiosa e, talvez, significativa inversão, visto que entre os índios, especialmente os Tupinambá, dava-se a tarefa às mulheres mais jovens, e preferencialmente virgens, como se verá adiante.

É necessário encarar a experiência etílica indígena como um conjunto de sistemas culturais que sofreram profundas transformações com a conquista europeia. Essas transformações não se limitam à simples substituição das tradicionais bebidas fermentadas pela muito mais potente aguardente, transformação que, em si mesma, já é plena de consequências. É muito evidente a existência de um ataque - às vezes consciente, como no caso dos jesuítas - a alguns aspectos perigosos e indesejáveis, do ponto de vista europeu, do consumo nativo de bebidas. Entre esses aspectos, cabe destacar o papel crucial desempenhado pelas mulheres em todos os passos do fabrico e consumo das bebidas, a associação das bebidas com as atividades xamanísticas, e o importantíssimo lugar das beberagens no sistema de guerra e vingança dos índios.

\section{Os documentos históricos e o problema do alcoolismo indígena}

Antes de tratarmos desses temas, contudo, é necessário discutir o problema do alcoolismo indígena. A figura do nativo bêbado é quase um ícone dos diferentes processos de colonização, e os autores que estudaram o drama do contato, especialmente nas Américas, são unânimes em afirmar a importância do alcoolismo como instância desagregadora das sociedades nativas. Como diz Nathan Wachtel (1998: 218), "um dos sintomas mais dramáticos da desintegração da cultura nativa e da angústia a que ela dava origem era o alcoolismo: um fenômeno observado por todos os cronistas". ${ }^{3}$ 
De fato, alguns dos relatos dos cronistas são particularmente eloquentes no que diz respeito à ação dos excessos etílicos como sintoma e como pivô da desagregação das sociedades ameríndias. Frei Bernardino de Sahagún, por exemplo, foi muito sagaz ao perceber a relação entre o álcool e a destruição dos sistemas culturais indígenas. Afirmando, em 1576, que os nativos tinham uma maneira de viver "muito conforme à Filosofia Natural e Moral", Sahagún debita à chegada dos espanhóis todos os males pelos quais passavam os nativos: "e porque eles derrocaram e lançaram por terra todos os costumes e maneiras de reger que tinham estes naturais e quiseram reduzi-los à maneira de viver da Espanha (...) perdeu-se todo o regimento que tinham" (Sahagún, 1992: 218).

A principal tragédia, para Sahagún, era o excesso de bebidas alcoólicas:

A todos nós parece que a causa principal disto é a bebedeira que, como cessou aquele rigor antigo, de castigar com a pena de morte as bebedeiras, embora sejam castigados açoitando-os, tosquiando-os e vendendo-os como escravos por anos ou por meses, este não é castigo suficiente para que parem de se embebedar (...), e são estas bebedeiras tão desregradas e prejudiciais à república e à saúde e salvação dos que a praticam, que por elas se causam muitas mortes porque se matam uns aos outros estando bêbados. (Sahagún, 1992: 218)

É transparente nesse trecho o papel do uso 'desregrado' das bebidas alcoólicas como uma das possíveis respostas ao impacto desagregador da conquista europeia. Tal resposta, detectada por muitos, tornou-se, ela própria, uma conveniente explicação para a derrota dos nativos diante dos europeus; de fato, a figura do índio bêbado uniu-se à do índio 'fraco' e 'pusilânime' na construção de um paradigma de inferioridade racial dos ameríndios (Gerbi, 1996). Um exemplo disso é dado por Aires do Casal, que em sua Corografia descreve os índios brasileiros, apresentando a embriaguez como sua principal característica.

Os aborígines ou povos brasileiros são geralmente bem feitos, enquanto pequenos; mas perdem a gentileza mui cedo; inconstantes, desconfiados, e apaixonados de todo o gênero de licor forte, que bebem sem medida, e com que de ordinário são furiosos e temíveis enquanto não lhes passa a embriaguez. (Casal, 1976: 36)

O autor praticamente repete a descrição do viajante francês, do século XVIII, Charles Marie de La Condamine (1992: 55): "pusilânimes e poltrões ao extremo, se a embriaguez não os transporta". Para Spix e Martius, os índios só abandonavam sua frieza e indolência "naturais" para se dedicar ao álcool:

Insensível aos prazeres do paladar, dado sobretudo à alimentação animal, o índio, em geral, é sóbrio, e, sem respeito a horário, contenta-se com atender à necessidade de refazer-se; até frequentemente jejua por comodidade. De outro 
lado, porém, quanto à bebida, é apaixonado da sua vinhaça ou cachaça, quando a pode obter. (Spix G Martius, 1976, v. I: 2.031)

O suposto vício da bebida por parte dos nativos chegou mesmo a ser apresentado como uma circunstância atenuante para o roubo de terras indígenas praticado pelos europeus e pela sociedade nacional.

Se considerarmos por outro lado que a sua possessão [dos índios] também se fundava no esbulho que uns contra os outros praticavam quotidianamente, e que todo o seu direito repousava na violência, na conquista e na guerra, ordinariamente deliberada no meio de brutas orgias de sangue e vinho, então o abuso da espoliação, de que os europeus são acusados, ficará imediatamente atenuado. (Lisboa, 1976: 174)

Dessa forma a intemperança etílica, entendida não como uma doença, mas como 'imoralidade', é parte central dos discursos e imagens construídos pelos europeus a respeito dos índios. Contudo, a história dos Maxacali - e muitas outras não nos deixa esquecer que existem nessas descrições e comentários dois fenômenos sociais concretos que devem ser interpretados pelo historiador. De um lado, temos as 'bebedeiras' tradicionais, feitas com as mais diversas bebidas fermentadas, em que os índios se tornavam 'furiosos e temíveis' e que eram encaradas pelos primeiros missionários como um dos principais, senão o maior, obstáculo para a conversão daqueles pagãos.

Y lo que más los tiene ciegos, es el inçassiable appetitu que tienem de venguança, en lo qual consiste su honra, y con esto el mucho vino que beven, hecho de raízes o de fruitas, que todo a de seer masticado por sus hijas y otras moças, que de solas ellas en quanto son vírgines usão pera este officio. Ni sé otra mejor traça de infierno que ver una multitud dellos quando beven, porque pera esso combidan de mui lexos; y esto principalmente quando tienem de matar o comer alguna carne humana, que ellos traen de moquen. (Leite, 1954, v. II: 132-133) ${ }^{4}$

Tais sessões de embriaguez possuíam uma profunda relação com o sistema de guerra e vingança das sociedades ameríndias, apresentando-se como um instrumento mnemônico em que a história de cada grupo, as crônicas de suas guerras e deslocamentos, as agruras e angústias causadas pelas ações dos inimigos e seus atos violentos, as honrarias conseguidas por seus campeões eram lembradas e permanentemente reconstruídas: "de facto, quando estão mais bêbados, renovase a memória dos males passados, e começando a vangloriar-se deles logo ardem no desejo de matar inimigos e na fome de carne humana (Leite, 1954, v. II: 194). ${ }^{5}$ 
Como percebeu brilhantemente o jesuíta Jácome Monteiro, em 1610:

tomando novos nomes, conforme aos contrários que matam, dos quais chegam alguns a ter cento e mais apelidos, e em os relatar são mui miudos, porque em todos os vinhos, que é a suma festa deste gentio, assi recontam o modo com que os tais nomes alcançaram, como se aquela fora a primeira vez que a tal façanha acontecera; e daqui vem não haver criança que não saiba os nomes que cada um alcançou, matando os inimigos, e isto é o que cantam e contam. Contudo os cavaleiros nunca fazem menção dos seus nomes, senão quando há festa de vinhos, na qual só se ouve a prática da guerra, como mataram, como entraram na cerca dos inimigos, como lhe quebraram as cabeças. Assim que os vinhos são os memoriais e crónicas de suas façanhas. (Monteiro, 1949: 409-410)

\section{O álcool e as relações de gênero}

Ao lado dessa função guerreira, masculina poderíamos dizer, o fabrico e consumo das bebidas fermentadas ocupam um lugar todo especial no sistema de relações de gênero das sociedades indígenas (Fernandes, 2003). Na maior parte das sociedades indígenas sul-americanas, tais bebidas - a chicha amazônica ou o cauim tupinambá, entre outras - ocupam um lugar central na vida cerimonial, e são um produto exclusivamente feminino: as mulheres, na maioria dos casos, fornecem o trabalho agrícola ou de coleta necessário, fabricam e decoram os recipientes apropriados ao preparo das bebidas e, em última análise, decidem ou influenciam decisivamente sobre sua utilização.

O complexo cultural formado pelas técnicas sociais da cerâmica (um produto geralmente feminino) e das bebidas fermentadas articulava-se ao canibalismo na construção de uma metafísica da interioridade e exterioridade social. Essa metafísica constitui uma porta de entrada para a compreensão das relações de gênero não apenas nas sociedades atuais, mas também nas do passado.

Enquanto produto marcado, prática e simbolicamente, pela feminilidade, as bebidas poderão nos guiar na elucidação da natureza das relações de gênero nas sociedades amazônicas. Ali, a divisão simbólica do trabalho entre os gêneros põe as mulheres associadas à horticultura e os homens à caça e à guerra; mas o verdadeiro correlato da atividade cinegética e guerreira masculina não é a simples produção feminina dos alimentos vegetais, e sim a elaboração das bebidas fermentadas. A associação entre estas e a antropofagia, por fim, é um tema relativamente difundido no mundo ameríndio: recordemos apenas a célebre cauinagem canibal dos Tupinambá quinhentistas. (Viveiros de Castro, 1992: XVI-XVII) 
Um exemplo contemporâneo atesta o papel feminino na cultura etílica dos nativos sul-americanos. Stephen Thompson, referindo-se aos Cubeo da Amazônia Ocidental, aponta o fato de que a fabricação da chicha requer um aumento considerável na quantidade de trabalho feminino, porém "entre muitos grupos este trabalho adicional é inteiramente voluntário", já que significa a possibilidade de ascensão a posições de prestígio associadas à proficiência no cultivo da mandioca e no fabrico da bebida (Thompson, 1977: 909).

A importância da atividade feminina é ressaltada quando se sabe que as bebidas não eram apenas importantes, mas verdadeiramente indispensáveis à vida cerimonial dos Tupinambá. Para Alfred Métraux (1950: 321), "nada acontecia de importância na vida social ou religiosa dos tupinambás que não fosse seguido de vasto consumo de certa bebida fermentada conhecida pelo nome de cauim". Isso era válido também para os Tupinambá do Maranhão, como nos diz Abbeville (1975: 237):

Se esses índios são grandes dançarinos são ainda melhores bebedores; em verdade não costumam beber senão nos dias de reuniões festivas, como quando matam algum prisioneiro para comer, quando deliberam sobre a guerra, em suma quando se juntam por prazer ou para tratar de negócios importantes, os quais não seriam bem sucedidos se antes não preparassem o cauim e não cuidassem à vontade. ${ }^{6}$

O capuchinho francês toca aqui em um ponto fundamental: "não costumam beber senão nos dias de reuniões festivas". Havia um controle social do consumo de bebidas, uma demarcação cerimonial e religiosa que limitava, quando não impedia, a ocorrência de 'alcoolismo' entre os índios no seu modo de vida tradicional. Não se trata apenas do pequeno potencial alcoólico das cervejas e hidroméis de baixa fermentação dos índios, pois eles eram efetivamente embriagantes. Referindo-se a certa bebida nativa, Spix e Martius afirmam que "tem sabor semelhante ao de nossa cerveja de malte: tomando-se muito, embriaga, efeito que no fim da festa se percebia de sobra pelos pulos desordenados e pelo canto delirante de li-lá-lá" (Spix G Martius, 1976, v. I: 200).

Não obstante, as pesquisas a respeito do alcoolismo mostram que o contexto social em que se dá a experiência etílica é fundamental para a maior ou menor ocorrência do fenômeno. Criticando a visão de que o alcoolismo tenha uma origem 'genética', independente do contexto social, Stanton Peele (1987) lembra que os nativos americanos mostram as maiores taxas de alcoolismo entre os grupos étnicos norte-americanos, e afirma que os índios têm um metabolismo que favorece a ocorrência do alcoolismo (intoxicam-se com maior rapidez e com menores quantidades de álcool). 
Contudo, como mostra Peele (1987), os sino e nipo-americanos, que possuiriam as mesmas reações metabólicas dos índios, apresentam as menores taxas de abuso de álcool entre todos os grupos étnicos dos Estados Unidos, ao passo que os nativos americanos apresentam os maiores valores. De fato, os índios que apresentam os maiores problemas são justamente os que têm relações mais íntimas, e mais desiguais, com os brancos.

\section{Destilados: o presente envenenado dos europeus}

Essa constatação não deve, é claro, obscurecer o fato de que houve uma alteração drástica no regime alcoólico dos índios, alteração que, somada às catástrofes das doenças, escravidão, 'reduções' e 'descimentos', representou um profundo golpe para aquelas sociedades. Refiro-me à introdução das bebidas destiladas, muito mais potentes que as fermentadas, e cujo processo de fabricação pertencia aos 'caraíbas' chegados da Europa. Como escreve Fernand Braudel a respeito da conquista europeia de novos mundos:

O alambique deu à Europa uma superioridade sobre todos estes povos, a possibilidade de fabricar um licor superalcoólico, à escolha: rum, uísque, Kornbrand, vodca, calvados, bagaceira, aguardente, gim: que é que se deseja tirar do tubo refrigerado do alambique? (...) é inegável que a aguardente, o rum e a agua ardiente (o álcool da cana) tenham sido presentes envenenados da Europa para as civilizações da América. (...) Os povos indígenas sofreram enormemente com este alcoolismo que se lhes oferecia. (Braudel, 1995: 220-221)

A questão das origens dos processos de destilação ainda está em aberto. O princípio da destilação parece ter sido descoberto no século I d. C., embora existam grandes controvérsias a respeito (Tannahill, 1988). No século IX a destilação para a produção de cosméticos era conhecida por árabes e persas: os árabes produziam a partir do álcool destilado um delineador de olhos, o kohl, de onde nos vêm a palavra 'álcool' (de al-kohl ou al-kuhl).

O que é realmente certo é que o alambique europeu foi inventado pelos alquimistas e boticários, no século XI, por razões médicas: o álcool destilado de vinho, a acqua vitae, será sempre visto como um remédio até os fins do século XV (Braudel, 1995). ${ }^{7}$ Segundo Fernand Braudel, a transformação se dará na passagem do século XV para o XVI: em 1496 a cidade de Nuremberg era forçada a proibir a venda de álcool em dias de festa; três anos antes um médico local alertava: "já que agora toda a gente tomou o hábito de beber acqua vitae, será necessário lembrar a quantidade que se pode beber e aprender a beber conforme a capacidade de cada um, para quem quiser comportar-se como um fidalgo" (Braudel, 1995: 216). 
Ainda para Fernand Braudel, os países nórdicos foram mais avançados no uso das aguardentes que os latinos: Veneza só cobra impostos de importação sobre a acqua vitae em 1596, e em Barcelona só se fala nisso no século XVII. Os popularizadores do 'vinho queimado' entre os latinos parecem ter sido os holandeses, a partir do século XVII (Braudel, 1995). Nos séculos XVI e XVII explodiu uma verdadeira moda da bebedeira entre os povos nórdicos, no que não foram seguidos pelos latinos. Um italiano, escrevendo nessa época, agradecia a Deus, já que, "entre as muitas pestes que nos vêm de além das montanhas, a pior de todas ainda não nos alcançou, que é a de se considerar a embriaguez não como um assunto para gargalhadas, mas como um mérito" (Tannahill, 1988: 243).

Percebe-se, portanto, que as potentes bebidas destiladas eram, ao tempo das navegações, uma novidade até mesmo para os europeus, e ainda mais para os latinos, o que nos permite inserir, ao lado das inovações nos transportes e nos armamentos, as bebidas destiladas entre as descobertas e invenções que possibilitaram e facilitaram a conquista europeia dos novos mundos. Os espanhóis, como sempre, tinham uma notável consciência do papel das bebidas como arma de conquista e, ao contrário dos portugueses, eram bastante loquazes a respeito do assunto. Em 1786, Bernardo de Gálvez, vice-rei do México, propunha disseminar o pulque ${ }^{8}$ entre os apaches, que não a conheciam, afirmando que seria um ótimo meio de lhes criar "uma nova necessidade que os obrigue estritamente a reconhecer a sua dependência forçosa em relação a nós" (Braudel, 1995: 221).

Embora se refira a uma bebida fermentada, e de origem nativa, Gálvez toca em um ponto importante ao ressaltar o caráter de 'dependência' das relações interétnicas, em um processo que transforma bens inacessíveis à maioria dos povos indígenas, como as armas, a pólvora, os instrumentos de ferro e as bebidas destiladas, em bens essenciais para a reprodução social dos nativos.

Em todos os testemunhos do contato interétnico, tanto os do passado quanto os do presente, percebe-se claramente o fascínio demonstrado pelos ameríndios em relação às maravilhosas ferramentas europeias, que se assemelhavam - aos olhos dos nativos - às obras de seus heróis culturais, chamados de maí (ou maíra) e karaiva (não por acaso os mesmos nomes dados a franceses maí - e portugueses - caraíba - pelos Tupinambá).

Esse fascínio fica claro, por exemplo, na descrição feita por Caminha da confecção de uma cruz:

Enquanto cortávamos a lenha, faziam dois carpinteiros uma grande Cruz, dum pau, que ontem para isso se cortou. Muitos deles vinham ali estar com os carpinteiros. E creio que o faziam mais por verem a ferramenta de ferro com que a faziam, do que por verem a Cruz, porque eles não tem coisa que de ferro seja, e cortam sua madeira e paus com pedras feitas como cunhas, metidas em um pau entre duas talas, muito bem atadas. (Ribeiro G Moreira Neto, 1992: 89) 
Estudando os Kaiapó, Terence Turner (1993) analisou de forma arguta o sentimento 'metafísico' envolvido no olhar indígena sobre os instrumentos do homem branco. Possuir os instrumentos europeus é, mais do que uma necessidade prática, um meio simbólico de se anular a atroz e humilhante diferença tecnológica entre os nativos e esses maí recém-chegados.

O desejo kaiapó por mercadorias brasileiras se deve apenas em parte à sua maior eficiência e utilidade frente aos produtos nativos, e muito pouco a uma competição por prestígio fundada no "consumo conspícuo". O valor primordial da posse de mercadorias, para os Kaiapó, - especialmente objetos próprios para ser exibidos, como roupas, casas e gravadores - reside na neutralização simbólica da desigualdade entre eles e os brasileiros, na medida em que esta é definida em termos da posse dos produtos mais complexos e eficazes da indústria ocidental, e da capacidade de controlar a tecnologia a eles associada. (Turner, 1993: 61)

Embora não tenham, aparentemente, um valor 'prático', as novas bebidas apresentam também um caráter de complexidade e eficácia que as colocam ao lado dos objetos referidos por Turner. Seu processo de fabricação em alambiques e seu alto poder dopante, quando comparadas aos 'vinhos' indígenas tornam-nas objetos em que a diferença entre índios e brancos está simbolicamente bem determinada, fazendo delas, portanto, um bem de alto valor para os nativos.

As próprias bebidas fermentadas europeias surgiam como ícones de superioridade técnica. Jean de Léry deixou-nos um notável testemunho acerca de um primeiro contato dos Tupinambá com as bebidas europeias, contato em que fica patente a surpresa com que os índios encaram a eficiência etílica do produto europeu. O missionário francês, nesse trecho, reproduz um diálogo que teve com um dos chefes indígenas, em que descreve o ocorrido quando este chefe e outros nativos tomaram de assalto um navio português:

Surpreendemos uma vez (...) uma caravela de peros [portugueses], na qual, depois de mortos e comidos todos os homens e recolhida a mercadoria existente, encontramos grandes caramemos [tonéis e outras vasilhas de madeira] cheios de bebida que logo tratamos de provar. Não sei que qualidade de cauim era, nem se o tendes no vosso país; só sei dizer que depois de o bebermos ficamos por três dias de tal forma prostrados e adormecidos que não pudemos despertar. (Léry, 1975: 131)

Segundo Jean de Léry, os índios haviam encontrado tonéis de vinho espanhol, "com os quais os selvagens, sem o saber, festejaram a Baco. Não é pois de admirar que o nosso homem se tivesse sentido tão repentinamente atordoado" (Léry, 1975: 131). 
As bebidas europeias, e mais ainda as bebidas destiladas, tornaram-se um bem de troca por excelência entre os nativos e os europeus e brasileiros. A cachaça era produto indispensável nos inúmeros processos de 'pacificação' executados pelos europeus, como o ocorrido com os Mura da Amazônia, em fins do século XVIII: a lista de produtos oferecidos aos índios, envoltos na finalização de um conflito secular com os portugueses, mostra bem quais eram as suas prioridades: "10 alqueires de farinha, 4 dúzias de facas, 2 ditas de arpões de todo o peixe, 2 ditas de tartarugas, 6 ditas de sararacas, 2 cabeças de linhas, 1 milheiro de anzóis brancos e 4 frascos de aguardente de cana" (Mardel, 1786 apud Ferreira, 1974: 143, grifo meu).

Ao cruzar com sociedades indígenas, Spix e Martius deixavam bem evidente qual era o principal meio de aproximação com os nativos; ao encontraremse com alguns Mura que assavam tartarugas, pediam que se dissesse na língua geral "Camarada, venha já, traga tartarugas! Aqui temos cachaça!" (Spix G Martius, 1976, v. III: 109). ${ }^{9}$ Os mesmos naturalistas mostram que esse intercâmbio poderia ser ativamente buscado pelos próprios índios, o que não deixava de se configurar em risco para os nacionais. Referindo-se à sua estada em Caxias, no Maranhão, Spix e Martius dizem (1976, v. III: 234) que:

Nos primeiros dias de nossa estada, fomos certa vez, à tarde, atraídos à janela por berreiros na rua, onde se oferecia o singular espetáculo do bando de uns 50 índios, que passavam em completa nudez e incultura primitivas. Esses índios vinham, por instigação do seu principal (...) para obter dos habitantes peças de vestuário, machados, facas e toda espécie de miudezas, dando em troca, como presentes, grandes bolas de cera, plumas de belos coloridos e arcos e flechas delicadamente trabalhados. (...) e como a prudência manda tudo fazer para extirpar das numerosas tribos os sentimentos hostis hereditários, assim se esforçam os habitantes de Caxias em recebê-los bem e cumulá-los de fartas provisões de farinha, cachaça, fumo e tecidos de algodão de variegadas cores.

Embora a dependência indígena da cachaça fosse, muitas vezes, algo buscado conscientemente pelos europeus, o alcoolismo - ou, pelo menos, a intemperança etílica - também se constituía em um problema para estes. Assim como os jesuítas tiveram nas bebedeiras um de seus principais, senão o principal, obstáculo para a catequese, os pregadores holandeses - durante o domínio neerlandês no Nordeste, no século XVII - se sentiram impotentes para combater a óbvia predileção que os nativos dedicavam à cachaça vis-à-vis os seus sermões.

Em carta (datada de 1642) ao Conselho dos XIX, órgão executivo máximo da Companhia das Índias Ocidentais, o governo holandês de Pernambuco desistia de tentar converter os índios adultos, "dados os seus vícios inveterados, prostituição, alcoolismo e preguiça" (Mello, 1978: 221). Talvez a catequese reformada fosse ainda 
mais dificultada pela evidente contradição, certamente percebida pelos nativos, entre os discursos antialcoólicos dos pregadores reformados e os 'presentes de aguardente' muitas vezes feitos aos índios pelo próprio governo holandês (Mello, 1978).

Os portugueses não deixaram de tentar colocar obstáculos ao consumo indígena da aguardente. O Diretório pombalino (1757), por exemplo, possuía várias determinações que tentavam coibir a entrada da cachaça nas aldeias. Os autores dessa legislação concordavam com a ideia geral de que o excesso de álcool era a causa de todos os males que afligiam os índios, e tinham consciência dos usos que os colonos faziam da cachaça em suas relações com os nativos (Almeida, 1997, Apêndice: 6-7):

Mas concorrendo tanto para a incivilidade dos Indios os vicios, e abusos mencionados, naõ se póde duvidar, que o da ebriedade os tem reduzido ao ultimo abatimento; vicio entre elles taõ dominante, e universal, que apenas se conhecerá hum só Indio, que naõ esteja sujeito á torpeza deste vicio. Para destruir pois este poderoso inimigo do bem commum do Estado, empregaráõ os Directores todas as suas forças em fazer evidente aos mesmos Indios a deformidade deste vicio; (...) Porém como a refórma dos costumes, ainda entre homens civilizados, he a empreza mais ardua de conseguir-se, especialmente pelos meios da violencia, e do rigor; (...) Advirto aos Directores, que para desterrar nos Indios as ebriedades, e os mais abusos ponderados, usem dos meios da suavidade, e da brandura; para que naõ succeda, que degenerando a reforma em desesperaçaõ, se retirem do Gremio da Igreja, a que naturalmente os convidará de huma parte o horror do castigo, e da outra a congenita inclinaçaõ aos barbaros costumes, que seus Pays lhes ensinâraõ com a instrucçaõ, e com o exemplo.

O comuníssimo uso 'apaziguador' da aguardente por parte dos colonos, bem como as imperiais e abundantes distribuições de cachaça por viajantes como Spix e Martius mostram bem o quanto se deve ser crítico a respeito do sucesso dessas determinações. Os autores do Diretório, não obstante, conheciam bem os principais caminhos de chegada da aguardente aos índios, e eram cônscios do fato de que a cachaça era um poderoso bem de troca com os nativos. Tentou-se, portanto, impedir que as canoas de resgate amazônicas trocassem as drogas do sertão e outros produtos pela desejada aguardente, substituindo-a por "fazendas úteis à sua civilização":

Ficando pois na liberdade dos Indios ou vender seus fructos por dinheiro, ou comutalos por fazendas, na fórma que costumaõ as mais Naçoens do Mundo; sendo innegavelmente certo, que entre as mesmas fazendas, humas saõ nocivas aos Indios, como he a aguardente, e outra qualquer bebida forte; (...) que neste Estado he o siminario das maiores iniquidades, preturbaçoens, e desordens. (Almeida, 1997, Apêndice: 18) 
O Diretório proibia que as canoas que realizavam o comércio ribeirinho transportassem aguardente, sob a ameaça de penalidades severas aos cabos dessas embarcações:

Ordeno aos Directores, que apenas chegar ao Porto das suas respectivas Povoaçoes alguma Canôa, ou qualquer outra embarcação, a vaõ logo examinar pessoalmente (...) e achando na dita embarcação aguardente; (que naõ seja para o uso dos mesmos Indios que arremaõ na fórma abaixo declarada), prenderáõ logo o Cabo da dita Canôa, e o remetteráó a esta Praça a ordem do Governador do Estado; tomando por perdida a dita aguardente que se applicará para os gastos da mesma Povoaçaõ (...). (Almeida, 1997, Apêndice: 18)

Como se vê, apesar das proibições, o Diretório permitia que as canoas conduzissem "algumas frasqueiras de aguardente; ou para remedio, ou para gasto dos Indios da sua esquipaçaõ", frasqueiras que deveriam ser guardadas em confiança pelos diretores enquanto as canoas não seguissem viagem. Este tipo de ambiguidade, representada por um rigor metropolitano que se amolda às condições locais, marca, como sabemos, toda a legislação colonial relativa aos índios (PerroneMoisés, 1992), o que transparece nos conflitos entre os interesses dos colonos e os da Coroa, especialmente no que tange à utilização das bebidas fortes como 'arma de colonização'.

\section{Considerações finais}

À guisa de conclusão, é importante reafirmar alguns dos pontos básicos apresentados aqui. Se reconhecermos a existência de uma universal busca humana pelas substâncias psicoativas, entre as quais se destacam as bebidas alcoólicas, e se considerarmos que a maioria dos nativos brasileiros possuía suas próprias beberagens embriagantes, resta-nos analisar a questão do alcoolismo indígena, tema dos mais presentes nas fontes históricas.

Busquei demonstrar que o alcoolismo dos nativos brasileiros - além do fato inegável de que as bebidas destiladas têm um poder dopante, e debilitante, bem maior do que as fermentadas -, tal como entre outras populações 'primitivas' atingidas pela conquista europeia, é uma 'consequência' da desagregação de suas sociedades imposta pelo contato, consequência muitas vezes manipulada pelos interesses coloniais.

O alcoolismo indígena, assim como ocorre entre outras etnias, é uma decorrência do contexto social em que as bebidas são consumidas. Dessa forma, vemos que as sociedades nativas impunham limites claros ao consumo de bebidas alcoólicas, limites que configuravam um controle social da embriaguez, controle esse quase que completamente perdido com o processo da conquista. Mais do que 
a mudança do tipo de bebida, é no contexto social e em suas transformações que deveremos buscar as respostas para as questões colocadas pela documentação histórica.

Notas

1 Este capítulo é uma versão revisada de: Fernandes, A. F. Cauinagens e bebedeiras: os índios e o álcool na história do Brasil. Revista Anthropológicas, 13(2): 39-59, 2002. Texto republicado com autorização do autor e do editor da revista.

2 Carta de Pero Vaz de Caminha (apud Ribeiro G Moreira Neto, 1992: 85).

3 Ver também Braudel (1997) e Hemming (1995).

4 "Carta do P. Luís da Grã ao P. Inácio de Loyola, Roma (Bahia, 27 dez. 1554)".

5 "Carta do Ir. José de Anchieta ao P. Inácio de Loyola, Roma (São Vicente, fim de março de 1555)".

6 Ver também Cardim (1978: 104-105), Léry (1975: 128-129), Souza (1971: 311) e Fernandes (1989: 81).

7 A expressão acqua vitae permaneceu no nome de várias bebidas alcoólicas: eau de vie, akvavit, vodka, e na expressão gaélica uisge beatha, ou uisge, que a corruptela inglesa transformou em whisky. O brandy, por sua vez, provém da pouco poética expressão alemã Brandewine (vinho queimado) (Tannahill, 1988: 244).

8 Bebida asteca fermentada a partir do agave; o raciocínio do espanhol é igualmente válido para o uso das bebidas destiladas como armas de colonização, muito praticado entre ingleses (rum) e franceses (aguardente) na América do Norte, bem como na Austrália e nas ilhas do pacífico (Braudel, 1995; Mancall, 1995; Saggers G Gray, 1998).

9 Em meados do século XIX os chamados botocudos trocavam crianças de povos rivais, bem como produtos extraídos da Mata Atlântica por "ferramentas de metal e armas, roupa, alimentos e cachaça, sempre cachaça" (Dean, 1996: 177).

\section{Referências}

ABBEVILlE, C. História da Missão dos Padres Capuchinhos na Ilha do Maranhão e Terras Circunvizinhas. Belo Horizonte, São Paulo: Itatiaia, EdUSP, 1975.

ABDALA, I. Todo dia é dia de álcool: com o território ameaçado e subnutridos, os índios maxakalis tentam sobreviver à força destrutiva das bebidas. IstoÉ, 18 nov. 1998.

ALMEIDA, M. R. C. Metamorfoses Indígenas: identidade e cultura nas aldeias coloniais do Rio de Janeiro. Rio de Janeiro: Arquivo Nacional, 2003.

ALMEIDA, R. H. O Diretório dos Índios: um projeto de "civilização" no Brasil do século XVIII. Brasília: EdUNB, 1997. 
BRAUDEL, F. Civilização Material, Economia e Capitalismo. v. I (As Estruturas do Cotidiano). São Paulo: Martins Fontes, 1995.

CARDIM, F. Tratados da Terra e Gente do Brasil. São Paulo, Brasília: Cia. Ed. Nacional, INL, 1978.

CARNEIRO DA CUNHA, M. (Org.). História dos Índios no Brasil. São Paulo: Companhia das Letras, 1992.

CASAL, M. A. Corografia Brasílica ou Relação Histórico-Geográfica do Reino do Brasil [1817]. Belo Horizonte, São Paulo: Itatiaia, EdUSP, 1976.

DEAN, W. A Ferro e Fogo: a história e a devastação da Mata Atlântica brasileira. São Paulo: Companhia das Letras, 1996.

FERNANDES, F. A Organização Social dos Tupinambá. São Paulo: Hucitec, EdUNB, 1989.

FERNANDES, J. A. De Cunhã a Mameluca: a mulher tupinambá e o nascimento do Brasil. João Pessoa: Ed. UFPB, 2003.

FERREIRA, A. R. Viagem Filosófica pelas Capitanias do Grão-Pará, Rio Negro, Mato Grosso e Cuiabá. s. 1.: Conselho Federal de Cultura, 1974. (Memórias - Antropologia)

GERBI, A. O Novo Mundo: história de uma polêmica (1750-1900). São Paulo: Companhia das Letras, 1996.

GIUCCI, G. Viajantes do Maravilhoso: o Novo Mundo. São Paulo: Companhia das Letras, 1992.

HEMMING, J. Red Gold: the conquest of Brazilian indians. Chatham: Papermac, 1995.

HOLANDA, S. B. Caminhos e Fronteiras [1956]. São Paulo: Companhia das Letras, 1994.

LA CONDAMINE, C. M. Viagem pelo Amazonas (1735-1745). Rio de Janeiro, São Paulo: Nova Fronteira, EdUSP, 1992.

LEITE, S. Cartas dos Primeiros Jesuítas do Brasil. Coimbra: Tipografia da Atlântida, Comissão do IV Centenário da Cidade de São Paulo 1954. 3 v.

LÉRY, J. Histoire d'un Voyage Fait en la Terre du Brésil. Genebra: Droz, 1975.

LISBOA, J. F. Crônica do Brasil Colonial: apontamentos para a história do Maranhão. Petrópolis: Vozes, 1976.

MANCALL, P. C. Deadly Medicine: indians and alcohol in Early America. Ithaca, London: Cornell University Press, 1995.

MELlO, J. A. G. Tempo dos Flamengos: Influência da Ocupação Holandesa na Vida e na Cultura do Norte do Brasil. Recife: Governo do Estado, 1978. (Coleção Pernambucana)

MÉTRAUX, A. A Religião dos Tupinambás e suas Relações com a das Demais Tribus Tupi-Guaranis. São Paulo: Cia. Ed. Nacional, 1950.

MONTEIRO, J. Relação da província do Brasil, 1610. In: LEITE, S. História da Companhia de Jesus no Brasil. v. VIII. Rio de Janeiro: Civilização Brasileira, 1949.

MONTEIRO, J. M. Negros da Terra: índios e bandeirantes nas origens de São Paulo. São Paulo: Companhia das Letras, 1994. 
PEELE, S. B. A moral vision of addiction: how people's values determine whether they become and remain addicts. Journal of Drug Issues, 17 (2): 187-215, 1987.

PERRONE-MOISÉS, B. Índios livres e índios escravos: os princípios da legislação indigenista do período colonial (séculos XVI a XVIII). In: CARNEIRO DA CUNHA, M. (Org.). História dos Índios no Brasil. São Paulo: Companhia das Letras, 1992.

POMPA, C. Religião como Tradução: missionários, Tupi e Tapuia no Brasil colonial. Bauru: EDUSC, Anpocs, 2003.

RAMINELLI, R. Imagens da Colonização: a representação do índio de Caminha a Vieira, 1994. Tese de Doutorado, São Paulo: FFLCH, Universidade de São Paulo.

RIBEIRO, D. G MOREIRA NETO, C. A. A Fundação do Brasil: testemunhos 1500-1700. Petrópolis: Vozes, 1992.

SAGGERS, S. G GRAY, D. Dealing with Alcohol: indigenous usage in Australia, New Zealand and Canada. Cambridge: Cambridge University Press, 1998.

SAHAGÚN, B. Relação etnográfica de Bernardino de Sahagún sobre a degeneração da disciplina e dos costumes indígenas causada pela destruição de suas idolatrias. In: SUESS, P. (Org.). A Conquista Espiritual da América Espanhola. Petrópolis: Vozes, 1992.

SALVADOR, V. História do Brasil (1500-1627). São Paulo, Brasília: Melhoramentos, INL, 1975.

SOUZA, G. S. Tratado Descritivo do Brasil em 1587. São Paulo: Cia. Ed. Nacional, EdUSP, 1971.

SPIX, J. B. G MARTIUS, C. F. P. Viagem pelo Brasil (1817-1820). São Paulo: Melhoramentos, IHGB, Imprensa Nacional, 1976. $3 \mathrm{v}$.

SUESS, P. A Conquista Espiritual da América Espanhola. Petrópolis: Vozes, 1992.

TANNAHILL, R. Food in History. London: Penguin Books, 1988.

THOMPSON, S. I. Women, horticulture and society in tropical America. American Anthropologist, 79: 908-910, 1977.

TURNER, T. De cosmologia a história: resistência, adaptação e consciência social entre os Kaiapó. In: VIVEIROS DE CASTRO, E. G CARNEIRO DA CUNHA, M. (Orgs.). Amazônia: etnologia e história indígena. São Paulo: NHII-USP, Fapesp, 1993.

VAINFAS, R. A Heresia dos Índios: catolicismo e rebeldia no Brasil colonial. São Paulo: Companhia.das Letras, 1995.

VIVEIROS DE CASTRO, E. Apresentação. In: VILAÇA, A. Comendo como Gente: formas do canibalismo wari'. Rio de Janeiro: EdUFRJ, Anpocs, 1992.

WACHTEL, N. Os índios e a conquista espanhola. In: BETHELL, L. História da América Latina: a América Latina Colonial. v. I. São Paulo, Brasília: EdUSP, Funag, 1998. 


\section{'Mansidão de Fogo': aspectos etnopsicológicos do comportamento alcoólico entre os Bororo ${ }^{1}$}

A preocupação com a saúde indígena é cada vez maior nos círculos acadêmicos e nos órgãos de Estado, e os estudos que envolvem os problemas de saúde pública e de saúde mental em etnias específicas - reflexo de uma realidade gritante que não pode mais ser ignorada - apesar de poucos, são promissores.

O problema da difusão do álcool entre os índios Bororo de Mato Grosso é tão sério que chama atenção a falta da sua menção em quase todas as análises antropológicas e levantamentos etnográficos desse povo tão estudado. Parece uma conspiração de silêncio diante de uma realidade que todo o mundo conhece, instigada talvez pelo purismo das abordagens tradicionais, ou pela falta de instrumentos teóricos adequados ao estudo de um produto da adaptação nas relações interétnicas que não é muito agradável à consciência dos setores ideologicamente dominantes nos campos político e científico.

Além de bem conhecido popularmente (constituindo um traço de uma identidade estigmatizada, a de 'beberrões'), o problema é muito antigo, remontando aos primeiros contatos entre essa nação e os conquistadores. Famosos viajantes europeus dos sertões brasileiros no século XIX, como Hércules Florence (1977), já nos idos de 1820, faziam descrições e relatórios pictográficos de inúmeras cenas onde intervêm Bororo bêbados.

É um pressuposto amplamente aceito entre os investigadores do alcoolismo entre indígenas, seja da América do Norte ou do Sul (Waddell G Everett, 1980; Simonian, 1997), que o álcool destilado foi usado pelos conquistadores como uma arma de dominação e de extermínio. Isso foi feito em Mato Grosso, de forma intencional, por bandeirantes primeiro e, depois, por militares e fazendeiros. E, de forma não intencional, pela própria difusão econômica da cana-de-açúcar que implicava a instalação de alambiques e o comércio de aguardentes para a população geral. "Antigamente o branco matava o índio a tiro, hoje mata com garrafas de pinga". ${ }^{2}$

Mas por que alguns povos indígenas aceitaram seu consumo imediatamente e outros não? Por que se difundiu largamente o consumo de álcool entre os Bororo e não, da mesma forma, entre etnias vizinhas geograficamente? Por 
que esse elemento incorporou-se à cultura acompanhando as transformações culturais, na dinâmica social e na personalidade bororo? Por que o mesmo fato não ocorreu com outras etnias do Mato Grosso, que também consomem bebidas alcoólicas?

Para se buscar responder a perguntas desse tipo, é necessário primeiro uma investigação a respeito da história do contato interétnico, do papel do álcool no processo de 'pacificação' dessa determinada sociedade e, principalmente, da ressonância, da reação subjetiva coletiva, da significação que tais fatos adquiriram na personalidade do povo bororo.

\section{Considerações etnográficas sobre os Bororo}

Os Bororo foram outrora uma nação poderosa, cujo território abrangia os limites naturais dos rios Paraguai ao oeste, Araguaia ao leste, das Mortes ao norte e Taquari-Coxim ao sul, ocupando toda a faixa sul do atual estado de Mato Grosso. Nesse local têm-se hoje as maiores cidades do estado: Cuiabá, Rondonópolis, Cáceres e Barra das Garças. Aos Bororo restaram pequenas parcelas da área de ocupação ancestral. Isso nos diz duas coisas importantes: Primeira, esses índios (junto com outros, certamente) estavam no meio da rota dos bandeirantes na ocupação do centro-oeste, o famoso 'caminho das monções'. Segunda, esse povo forma uma das bases étnicas da atual população mato-grossense, resultado de relações interétnicas estabelecidas, sucessivamente, por meio da escravidão, do trabalho assalariado e dos casamentos com os agentes do colonialismo.

À época da pesquisa, os Bororo distruibuíam-se em oito aldeias de não mais de cem habitantes cada. Cinco delas se localizavam ao longo da bacia do rio São Lourenço, sendo tuteladas apenas pela Fundação Nacional do Índio (Funai), e três na bacia do rio das Garças, onde atuavam também missionários salesianos.

Apesar de terem sido forçados a sedentarizar-se, conservam ainda características nômades, apresentando uma população flutuante em ocasião de cerimônias, como por exemplo, funerais, falta de víveres por escassez sazonal e, especialmente, como resultado de conflitos territoriais interétnicos e mesmo desavenças familiares.

Os Bororo são tradicionalmente caçadores, pescadores e coletores, tendo uma agricultura rudimentar de poucas espécies. Vivem da comercialização de peixe, artesanato, prestação de serviços e, sobretudo, de aposentadorias rurais. Falam uma língua classificada tradicionalmente como pertencente ao tronco macro-jê. Entretanto, a juventude das áreas salesianas prefere o português. Suas aldeias são, via de regra, circulares, com as unidades residenciais dispostas em torno de uma grande casa central, a 'casa dos homens'. Eles estão organizados em metades matrilineares e exogâmicas, com quatro clãs cada qual. Cada clã é 'proprietário' de 
certas plantas, animais, cores, cantos, danças, nomes, tradições, habilidades, segredos, utensílios, pinturas corporais e enfeites especiais; propriedade essa que proporciona um sentimento de individualidade tanto às pessoas quanto às unidades sociais referidas.

A instituição bororo por excelência é o funeral. Talvez não haja povo no mundo que 'saiba cuidar melhor dos mortos', executando longos e complexos rituais que duram, ainda hoje, até três meses, e que reordenam todo o universo de sociabilidade desse povo e a sua vida cotidiana. No funeral, manifestam-se todas as tradições, a vida espiritual, artística, social, emocional e material. Sua produção é considerada como 'trabalho' do mais alto grau: produção de enfeites, danças, cantos, representações, lamentos, zunidores secretos, competições, refeições, e o longo processamento do cadáver até obter ossos limpos e enfeitados com penas coloridas para o enterro secundário.

Outrora, era durante os rituais e na comunicação com as almas (aróes) que os Bororo fumavam e bebiam muito, diversos tipos de bebidas tradicionais, tanto por seu valor simbólico como para poder resistir a longos e extenuantes esforços físicos despendidos. Tradicionalmente produziam o iwóro, bebida fermentada à base de palmito de acuri, que requer vários dias para se obter em quantidades consideráveis. Hoje consomem abundantemente água com açúcar, refrigerantes e bebidas alcoólicas industrializadas e também apresentam o hábito compulsivo de fumar.

\section{Os comportamentos alcoolistas}

O gosto e o costume de consumir bebidas alcoólicas é generalizado entre os Bororo. Homens e mulheres, velhos e jovens, ou já beberam em alguma época ou são manifestamente dependentes. Apenas uma minoria se abstém com muito esforço, dado o meio ambiente tentador, mas depois de um tempo variável, as recaídas são quase certas.

Todos os observadores consultados concordam em afirmar que o hábito de beber álcool entre os Bororo não segue os mesmos padrões da população geral, não indígena. Esses índios bebem de forma intermitente. Até mesmo os mais crônicos passam períodos (até longos) sem beber, fato que dispararia uma 'síndrome de abstinência', com sintomas de sofrimento agudo, nos alcoolistas não índios, dada a dependência física que neles se configura.

A explicação dessa diferença no padrão de dependência física, além de fatores genéticos e metabólico-enzimáticos que não foram pesquisados ainda entre os Bororo está, a nosso ver, em uma razão prática. Eles nunca tiveram acesso à bebida destilada de maneira contínua e permanente, basicamente por motivo econômico e pela distância dos locais de fornecimento. Está aí outra diferença dos 
comportamentos entre as aldeias: nas mais afastadas das cidades, o consumo é mais circunscrito à situação. Por exemplo, no meio do Pantanal,

Bororo bebe álcool só quando o barco sobe, aí então uma semana de bebedeira. Bororo não chega a ser crônico, nem a ter síndrome de abstinência, Bororo bebe só quando tem oportunidade, e eles bebem enquanto não acabar, igual fazem com a comida, eles não guardam... $O$ índio na cidade bebe sempre porque tem fornecimento. (Mara Rúbia Enoré) ${ }^{3}$

Se as condutas alcoólicas dos Bororo têm algum padrão, este aproximase do que tradicionalmente em psiquiatria denomina-se 'dipsomania', ou 'alcoolismo explosivo'. Vejamos:

Condutas alcoólicas paroxísticas e intermitentes, periódicas, raramente regulares, precedidas de sinais premonitórios como lassidão, tristeza, desgosto de viver, insônia, inapetência, excitação sexual etc. Trata-se de uma necessidade imperiosa, absoluta, irresistível, que afugenta da consciência qualquer outra representação. Após o primeiro copo o doente é incapaz de se deter, bebe sem freio até a embriaguez amnésica. Com frequência, o acesso acompanha-se de comportamentos totalmente em contraste com sua personalidade normal: fugas, pensamentos e ações criminais, comportamento sexual anormal, e inclusive suicídio. Existe uma perda completa de controle. Habitualmente o doente é encontrado depois totalmente obnubilado, em qualquer canto. Então experimenta remorso, desgosto e, depois da saída da confusão e do torpor, apresenta um estado de matiz melancólico mais ou menos acentuado. (Ey, Bernard G Brisset, 1974: 365-366, tradução livre)

Os Bororo bebem habitualmente álcool de farmácia ou de carro, no começo temperado meio a meio com açúcar e limão, mais tarde é bebido puro 'até cair'. Geralmente a aldeia inteira acompanha todas as fases da bebedeira: "primeiro, euforia e gritos rituais; depois, choro ou brigas violentas; e, finalmente, cair anestesiado por horas" (Bordignon, 1996: 3).

Outro padrão que emerge da observação é a ingestão sempre socializada, grupal e, decorrente disso, o fenômeno da pressão grupal para beber, grande reforçador do alcoolismo coletivo. Tal fato foi observado por outros autores.

O comprador de bebida alcoólica, geralmente já um pouco tomado faz questão de chamar os companheiros mais próximos para beber juntos. Se alguém recusar, ele insiste até outro tomar um gole que depois puxa vários outros. Culturalmente falando, para o Bororo recusar um presente é uma afronta muito grande, e tem anciãos estimados por todos, os mesmos que denunciam publicamente os abusos das bebidas alcoólicas, que não sabem dizer não a qualquer oferta de bebida. (Bordignon, 1996: 2) 
Poderíamos afirmar, sem temor de erro, que o consumo de álcool entre os Bororo atingiu o status de verdadeira instituição cultural, com iniciação dos jovens por parte dos mais velhos, e com brincadeiras entre as crianças imitando os adultos, quesitos necessários para a socialização de qualquer nova instituição (Berger $G$ Luckmann, 1974).

Mais outro aspecto importante desse 'alcoolismo explosivo' relaciona-se à tensão que se gera nos espectadores que não participam diretamente da bebedeira. Isso porque o consumo de álcool entre os Bororo de forma usual se associa a súbitas 'viradas de mesa' e condutas 'escandalosas' em público, sobretudo em cerimônias oficiais.

A situação chegou a tal ponto que os Bororo passaram a não ser mais convidados para atos oficiais por temor a esse tipo de cena. Uma intenção implícita de assustar, provocar, e mesmo de desconcertar (pelo menos nas relações interétnicas), se depreende desses episódios, e suas implicações serão desenvolvidas mais adiante.

\section{História: aspectos gerais}

Há uma discussão, entre os historiadores mato-grossenses, sobre a índole original dos Bororo ser ou não guerreira. Se há uma dúvida, é porque há margem para representá-los como pacíficos, coisa que não cabe aos outros povos que se enfrentaram com os conquistadores do Centro-Oeste, como os Guaicuru, os Paiaguá e os Kaiapó. Achamos produtiva essa discussão, porque diz respeito às nossas hipóteses sobre o processo de adaptação e sua relação com o álcool, o aspecto psicodinâmico da 'pacificação' imposta aos Bororo e aceita por eles.

Para alguns, os Bororo eram conhecidos tradicionalmente até o século XVIII (e não depois) como aliados dos portugueses e dos bandeirantes nas guerras contra as outras nações indígenas altamente resistentes e nas campanhas contra os missionários castelhanos (Caldas, 1887). Inicialmente pacíficos, eram domesticados facilmente e formavam grandes regimentos que combatiam lado a lado com os 'soldados do rei', especialmente sob as ordens de Antônio Pires de Campos (Carvalho, 1937 apud Viertler, 1990). Na região de Cuiabá houve, numa determinada época, Bororo domésticos e Bororo dos bandeirantes, ambos a serviço do branco (Viertler, 1990).

Entretanto, os Bororo ficaram conhecidos depois como cruéis guerreiros, donos de habilidades estratégicas particulares, de vigilância pacienciosa e ataques inesperados, totalmente camuflados e em formação de guerrilhas, virando o terror, o inimigo número um das populações rurais não indígenas até fins do século XIX. 
Por que os Bororo, diferentemente das outras nações do Brasil central, na época da conquista, de facilmente domesticáveis, guias, e 'soldados do rei' passam a ser os 'inimigos irreconciliáveis' que iriam tirar o sono dos colonizadores até 1886?

Vários fatores, especificamente históricos, podem esclarecer essa confusão. Primeiro, a quantidade de nomes que esses índios receberam ao longo dos anos Porrudo, Coroado, Coxiponé, Araé, Avavirá, Aripoconé, Cabaçal etc. (Bordignon, 1986), o que demonstra que só bem mais tarde foram reconhecidos como uma nação única, daí resultando em tratamento diferente. Segundo, fica claro que os 'brancos' atacavam de surpresa as aldeias novas que encontravam, sem averiguar se a natureza dos índios era pacífica ou guerreira, como foi o caso dos Coxiponé por Antônio Pires de Campos, que logo depois se vingaram defensivamente contra a bandeira de Moreira Cabral, nas margens do atual rio Coxipó, onde foi fundada Cuiabá. Terceiro, a mesma natureza individualista dos Bororo pode explicar reações diferentes, decisões diferenciadas com respeito ao inimigo, como vários episódios assim o indicam (Albisetti G Venturelli, 1962).

Sustentamos que não há como duvidar da agressividade defensiva e vingativa dos Bororo que resistiam aos colonizadores, para além das análises sobre a natureza guerreira ou não dessa nação. E outra coisa é mais do que certa: os Bororo que conviviam com os brancos eram escorraçados, quando não mais serviam aos seus propósitos imediatos, e tratados com desprezo, e até com violência, esquecendo-se qualquer aliança anterior. Assim começa a história de interesse, falsidade e traição.

A fundação de Cuiabá (associada à corrida pelo ouro) mostrou aos Bororo as verdadeiras motivações dos brancos que até então peregrinavam sem rumo certo: dali em diante seriam os donos dessas terras, e isso não podia ser compartilhado com nenhum outro povo das redondezas, que se convertiam, ipso facto, em escravos ou inimigos.

Contra os Bororo inimigos, várias expedições foram enviadas atendendo ao clamor público para reprimi-los, tendo por vezes "resultados adversos, pois cometiam atos de barbaridade que provocavam mais vinganças e causando grande despesa" (Caldas, 1887: 19-20). Depois de muitas 'correrias' e 'caçadas' ao longo do século XIX, com trágicas mortes e sequestros de ambos os lados, aparece em cena o famoso tenente-coronel Duarte (nessa época alferes), que consegue a pacificação definitiva com o episódio conhecido como 'Rosa Bororo'.

O novo presidente da província, Galdino Pimentel, muda a política punitiva seguida até então e resolve tentar com meios de brandura e conciliação. Assim,

em 1886, visando seguir as instruções do Presidente, Duarte fez-se acompanhar das índias já civilizadas, dentre as quais Rosa Bororo, cujos filhos ficaram como reféns na capital, usando-as para persuadir seus parentes da aldeia (...) a 
aceitar a submissão e as vantagens da vida civilizada. As Bororo tiraram a roupa e pintaram-se de urucu, a fim de que não fossem mortas pelos companheiros (...) e aproximaram-se, sozinhas, da aldeia onde foram recebidas com entusiasmo [depois de uma semana]. Persuadidos, os Bororo vieram ao encontro da expedição de Duarte (...) para depor suas armas, arcos ornados com penas, em sinal de submissão e aliança. Mas Rosa, que voltara a se vestir apresentou-lhe os caciques e fazia o papel de intermediária, evitando rixas que pudessem reavivar as hostilidades. (Mello Rego, s. d. apud Viertler, 1990)

Devemos ressaltar aqui, antes de prosseguir, o elemento de falsidade e traição, ao serem as índias usadas como isca e tendo os filhos como reféns: "tiraram a roupa e pintaram-se" para enganar seus pares. As vantagens da 'civilização' às quais Rosa Bororo se referia para convencer os compatriotas eram: alimentação, roupas, brindes, instrumentos de trabalho a que não se sujeitavam (Mello Rego, s. d. apud Viertler, 1990). Ademais, "o alferes Duarte dava-lhes tudo o que pediam, e tornou-os mansos por meio desse método simples" (Steinen, 1940: 374).

Cria-se, então, a Colônia Militar de Teresa Cristina, perto da futura Rondonópolis, com a finalidade de manter a pacificação e 'catequizar' os índios, local no qual havia cerca de 3.595 Bororo (Viertler, 1990). Nesse momento histórico, estabelece-se uma aliança que pressupõe um pacto implícito que, a nosso ver, se mantém até hoje de uma forma congelada no tempo. Nas intenções do governo e dos militares, o fornecimento era com o fim de poder convencê-los, pouco a pouco, da obrigação do trabalho, até que adquirissem o hábito de promoverem, por si, a sua manutenção (Caldas, 1887). Mas os Bororo entenderam de forma mais simples e definitiva: "entregamos nossas armas para sempre, em troca dos bens da civilização, (...) para sempre". E dizemos congelado no tempo, porque até hoje os 'neocolonizadores' esperam que os índios trabalhem para eles; e os índios, até hoje, esperam que os 'brancos' lhes forneçam tudo, ficando desapontados e ressentidos continuamente, dadas as conhecidas políticas mutantes, burocráticas e de omissão (quando não corruptas) do Serviço de Proteção Indígena e Localização de Trabalhadores Nacionais (SPILTN), inicialmente, e da Funai, até hoje.

Três detalhes são relevantes nessa marcante e irônica situação histórica: os Bororo não eram convidados a trabalhar, enquanto observavam os soldados que eram obrigados a fazê-lo; quase todos eles foram logo batizados na Igreja tendo como padrinho, geralmente, o próprio governador (mais uma promessa 'eterna' de provisão?); e, como parte importante dos 'bens da civilização', foram 'presenteados' com a famigerada pinga.

Nós, inclusive, levantamos a trágica possibilidade de a pinga estar entre os presentes que Rosa Bororo levou e prometeu aos seus pares. Se assim foi, 
constitui-se em um verdadeiro 'presente de grego', com o qual se penetra na intimidade do inimigo e destroem-se todas as suas defesas.

O famoso etnógrafo Karl von den Steinen, que passou por Cuiabá e pela Colônia Teresa Cristina em 1887, a um ano somente da pacificação oficial, deixounos detalhes de como o álcool fazia parte central dessa 'iniciação nos bens da civilização': [na colônia militar] à esquerda estava o quarto de Duarte e à direita uma porta para a despensa, que era também depósito de cachaça, e cuja chave, nas relações com os índios, representava um grande papel (Steinen, 1940: 578).

Forneceu-nos também inúmeras cenas de alegres e constantes bebedeiras, de brigas entre índios e até provocação aos próprios militares induzida pelo estado de embriaguez. A agressividade indígena não mais amedrontava os militares, pois existia uma clara diferença entre um povo lúcido em armas e um grupo de indíviduos furiosos e agitados, mas complementamente embriagados.

A agressividade é canalizada agora contra seus pares, contra seus irmãos, e é isso o que objetivavam e conseguem os 'civilizados', os militares em particular, graças ao álcool. Agressividade caótica, sem força, e agressividade endógena, contra os iguais, é assim que será desse momento em diante, até os nossos dias.

Não podemos entrar aqui em detalhes sobre o padrão de pacificação conseguido pela Missão Salesiana a partir de 1902, entre os Bororo dos rios das Garças, Barreiro e Sangradouro. Os métodos usados, bastante diferentes dos civis e militares, conseguem também a submissão dos índios, dessa vez muito maior. Temos em ação uma catequese que tenta substituir a religião indígena; e uma pedagogia vitoriana, importada da Itália, revestindo-se de grande paternalismo por meio da educação no internato e das medidas organizadoras do trabalho e da vida cotidiana nas aldeias sob sua influência.

O 'pacto implícito' estabelecido assim entre os índios e os missionários foi: "Nós abandonamos as armas (e os costumes) se vocês nos dizem daqui em diante o que temos de fazer. Nós obedeceremos totalmente, mas por isso mesmo precisaremos sempre da sua direção".

Com o advento da legislação nacionalista de Getúlio Vargas, foi proibido falar na missão em idioma bororo, o que dificultou a realização de todos os rituais tradicionais, especialmente os funerais. É justo lembrar que essa imposição se estendeu às escolas dos postos indígenas das outras aldeias na época do SPILTN, mas a aculturação conseguida nas missões foi muito maior.

O álcool não entrava nas aldeias de influência salesiana, até que na década de 1970 os missionários decidiram distribuir uma dose semanal de pinga, depois das jornadas de trabalho, com a finalidade de regular e moderar um costume que começava a se infiltrar pela venda de álcool na região (Bordignon, 1996). O tiro saiu pela culatra: quando acabaram com a distribuição, pela força do 'pacto implícito', a dependência tinha se alastrado. 
A partir do Concílio Vaticano II, com a Teologia da Libertação, a política e os métodos da Missão Salesiana mudaram totalmente. A partir daí, busca-se a autodeterminação, deixando que os índios decidam seus destinos, mas isso confronta paradoxalmente com o 'pacto implícito'.

O terceiro grande padrão pacificador nas relações branco-Bororo foi o do marechal Rondon, que parece ter se distinguido dos modelos anteriores, pois "fez demarcar suas terras, assegurou-lhes trabalho nas obras de construção das linhas telegráficas (na fronteira entre Mato Grosso e Goiás, e no sul entre o rio S. Lourenço e o rio Coxim), e deu-lhes instrução e amparo de que careciam para sobreviver" (Riveiro, s. d. apud Viertler, 1990). Mas mantendo respeito às tradições, organização, hierarquia e divisão do trabalho tipicamente bororo (Viertler, 1990).

Costuma-se afirmar que a pacificação foi conseguida por Rondon exatamente por não usar de nenhum subterfúgio nem manobra duvidosa, porque entendeu perfeitamente que a violência indígena (no nosso caso, Bororo) era defensiva e de revanche, pela invasão colonial. Entretanto é preciso demarcar que historiadores locais registram um regime violento de trabalho com uma disciplina militar, que custou a vida a muitos índios (e soldados) pelo esforço exigido (Viertler, 1990), o que põe em xeque a posição daqueles que defendem a existência de distinções importantes entre os métodos de Rondon e de seus predecessores.

O meu avô me contou que quando Rondon apareceu por aí, a primeira coisa que oferecia era o álcool, e assim trazia bastante índio para trabalhar. Fazia demonstração pondo fogo no álcool, falando que era mágico, para induzir a beber. Falava que quem tomasse aquilo ia ter um grande poder, o mesmo poder do fogo; o poder de possuir o que queria, o poder de um grande guerreiro. (Mara Rúbia Enoré)

Embora não possamos garantir a veracidade histórica desse depoimento, demarca-se a permanência no imaginário indígena da associação entre os métodos de conquista - sempre identificados à traição (com argúcia, mentiras, falsidade, uso e manipulação, abandono, quebra de pactos) - com o álcool.

\section{Instituições e significação da história}

Recapitulando a história levantada, os Bororo foram atacados de surpresa em muitas oportunidades, mesmo tendo mostrado serem colaboradores; foram reduzidos à escravidão e servidão; foram usados como 'mercenários' contra outros índios; foram dizimados pela sífilis e outras doenças (às vezes de propósito!); e finalmente foram enganados coletivamente com uma manobra usando índias 'reféns' para entregarem as armas definitivamente com promessas de provisão perpétua, e tudo isso associado à introdução do álcool. 
Muitos povos indígenas foram conquistados de forma semelhante, mas o que nos interessa aqui é a reação subjetiva coletiva, a significação dada a esses fatos históricos, e isso só pode provir do ethos de um povo, dos seus valores, instituições e tipo de personalidade étnica. Podemos constatar, por meio da observação de campo, entrevistas pessoais e pesquisa bibliográfica e etnológica, uma grande sensibilidade desse grupo à traição e à ofensa, associada a sentimentos de desapontamento, ressentimento e mágoa, que parecem levar a reações de fechamento emocional, vitimização e mesmo de vingança, expressa atualmente de modo passivo.

A propensão à ofensa é muito facilitada devido à instituição do móri, central na cultura bororo, e que rege todos os intercâmbios, repara todas as perdas e soluciona todos os conflitos, seja com o mundo dos espíritos, com a natureza, com os animais domésticos, entre famílias, pessoas de todas as idades, até mesmo crianças. Móri é, ao mesmo tempo, vingança, compensação, retribuição, pagamento, valor e preço.

É difícil explanar nos limites deste texto a extensão desse conceito que permeia toda a vida bororo. Ele engloba desde um simples machucado, até a própria morte. No primeiro caso, aquele que se machucou pode por um lado bater no objeto, ou esperar receber móri do 'proprietário' do objeto. Já em relação ao segundo, os rituais funerários estão relacionados tanto com a vingança contra a natureza e contra os espíritos que provocaram a morte, como também podem representar uma espécie de compensação por parte do clã oposto para a família do morto, que fica em posição passiva recebendo tudo.

Um dos conceitos mais arraigados na mentalidade Bororo é justamente o de vingança $=$ móri, da qual procuram fugir. Qualquer má ação será castigada ou vingada. O castigo é deixado ao arbítrio da iniciativa particular. (...) O temor de um feitiço $=$ erúbo faz viver sobressaltados os faltosos. Furacões de rancor, ódio e vingança, existem potencialmente em seus corações. Raros são os dias em que não haja uma pequena ou grande desavença. (Albisetti G Venturelli, 1962: 287-289)

No âmbito interpessoal, e mesmo interfamiliar ou interclânico, o álcool assume uma das suas funções, a de alcançar a coragem para executar as vinganças que não são realizadas no ato em que ocorre a primeira ofensa, mas, posteriormente, nas situações de bebedeiras, valendo-se nos dias de hoje de armas brancas e de fogo.

Ilustrativa desse entendimento foi a exclamação de um irmão salesiano, depois de equipe de pesquisa observar uma briga feroz entre índios bêbados, um tentando se vingar do outro com arma branca, por ofensas passadas: "Quem disse que Bororo bebe para esquecer? Bororo bebe é para lembrar!". 
Porém, é no âmbito coletivo interétnico que o sentimento de ofensa e mágoa alcança entre os Bororo uma magnitude cada vez maior, pelo fato de serem acumulativos, repetitivos, históricos e de não haver possibilidade alguma de se vingarem explicitamente, haja vista a renúncia oficial das hostilidades, como se apreende nos depoimentos a seguir:

Os Bororo eram muito receptivos, alegres, meigos, como são até hoje os Mynky, mas têm muita sensibilidade para captar os maus-tratos; têm que responder, desabafar, aí passa, esquece, mas geralmente recua, recolhe, aí guardam as ofensas por anos e anos. São especialmente sensíveis às formas de rejeição falsas, fingidas. A pacificação toda foi uma coisa fingida, falsa. (Cecílio Epoburéu, enfermeiro bororo da Unidade de Saúde Indígena da Funai de Cuiabá, Mato Grosso do Sul)

Se faz algo para índio, se aproveitar da bondade, da confiança do índio, fica marcado toda vida. Feitiço do branco é muito poderoso, por isso fez beber... (Frederico Kógia Túgo, Bororo da aldeia de Meruri, Mato Grosso do Sul)

Sustentamos que há um poço sem fundo de mágoa e ressentimento e que a vingança se manifesta hoje passivamente. 'Vejam o que fizeram de nós!'. Parecem dizer-nos na posição psicológica de vítimas (e certamente foram vítimas). Vale ressaltar que não poucos 'brancos', especialmente políticos, cientistas sociais, humanistas e religiosos se sentem culpados e impotentes, e talvez, seja a indução deste sentimento nos não indígenas aquilo que os Bororo perseguem.

Toda pessoa que se aproxima dos Bororo conhece logo as queixas, a lamúria, a lástima, a resignação. Apresentam-se frequentemente como doentes e necessitados (e o são), exigindo ajuda pecuniária e de todo tipo, como credores eternos. A lei do móri nas relações interétnicas é unilateral: o Bororo não se sente obrigado a retribuir presentes aos civilizados, mas destes esperam abundantes pagas (Albisetti $G$ Venturelli, 1962).

Na compreensão dos Bororo, pelas suas representações de saúde-doença (e foi exigido dos pesquisadores que as respeitassem), o alcoolismo não é Bororo, está entre os Bororo. O alcoolismo é dos brancos, e o problema que ele (o Bororo) tem foi causado pelos brancos com a introdução da pinga: se estes são os causadores, são os únicos que podem e devem tirá-lo.

Os antigos lembram continuamente, passam para os mais novos, como foi a conquista; e se eles estão assim hoje, a primeira coisa é pôr a culpa no branco. Há muito ressentimento. Afirmam que a doença entrou com os brancos: 'Foi assim que eles entraram em nós, foi com bebida!' (Mara Rúbia Enoré) 
Uma palavra bororo, koriréboe $=$ kóri (dor) + re (ter) + bóe (coisa) 'coisa que tem dor' - nas suas três acepções, resume este ponto de vista: "1 aquilo que causa dor, zanga, ofensa, impaciência; 2 - pinga, qualquer bebida fortemente alcoólica; 3 - outra denominação para cobras venenosas" (Abisetti G Venturelli, 1962: 745). Ou seja, além do significado literal da forte sensação física que provoca o álcool, os Bororo sentem a introdução do álcool como uma das máximas ofensas, como o bote traiçoeiro de uma cobra que inocula veneno (físico e emocional, a mágoa), e estão esperando a vacina, ou consideram-se sem remédio.

\section{Personalidade bororo e suas possíveis correlações com o uso de bebidas alcoólicas}

A índole dócil, adaptativa e pacífica dos Bororo é bem conhecida de quantos entram em contato e chegam a conhecê-los bem. Crocker atribui um ethos pacífico a esse povo e, quanto ao passado guerreiro, afirma que se se engajaram em lutas apenas para defenderem-se contra agressões alheias ou vingarem seus mortos (Albisetti G Venturelli, 1962).

Os Bororo 'entregaram-se' não só no sentido militar, mas também no sentido relacional, do vínculo que vai se estabelecer com a sociedade dominante daí por diante. Eles acreditaram, fizeram um voto de confiança nas promessas e nas alianças que, sabemos, foram todas abandonadas posteriormente.

A 'pacificação' conseguida nos Bororo pelas autoridades civis, militares e religiosas (processo que os índios chamam mais honestamente de 'amansamento'), seguida do desapontamento, foi tão contundente (e cronologicamente associada ao álcool), que produziu uma mudança permanente na própria personalidade étnica ou modal (Devereux, 1972), relacionando-se a características de dependência extrema, exigência de provisão e atenção, e ressentimento profundo.

No ato da 'pacificação' e no processo da adaptação posterior, os Bororo renunciaram definitivamente a todo e qualquer ato defensivo, não só das suas terras e da sua cultura, mas das suas próprias personalidades individuais.

Em Janeiro de 1887, outro grupo de 400 Bororo resolveu aceitar a paz (...) Guiados pelo famoso cacique Mugúio Kuri, ingressou solenemente na cidade e depositou as armas aos pés do Capitão Duarte num monte tão grande que impressionou o povo cuiabano. (Bordignon, 1986: 21)

Na memória dos índios jovens, o processo de pacificação registra-se um pouco diferente, mas essencialmente é o mesmo:

O pai do meu tio passou para nós que os índios Bororo de antigamente eram muito revoltados, muito bravos! Que branco para amansar, deixava 
coisas no caminho: se interessava, eles levavam, por exemplo, o açúcar. Aí teve um que deixou uma lata de querosene com álcool; um Bororo provou e bebeu, ficou alegre, cantava, brincava. Outro perguntou: "Esse troço é bom?". - "Ah! Pode beber!". Antigamente Bororo foi amansado com bebida alcoólica porque era muito bravo, eram muito revoltosos, porque atacavam muito o índio. Os Bororo se entregaram eles mesmos. Mas índio bravo era amansado, acostumando com a pessoa que dá comida, dá coisas que eles querem, aí fica calmo. Eu ouvi uma história onde vários índios Bororo foram amansar outros índios: deram machado, facão, açúcar, ficaram por perto até que acostumou, fizeram igual tinham feito com eles. (Benedito Tuakebóu, Bororo de Perigara, Mato Grosso do Sul)

A entrega das armas com a promessa de provisão perpétua (na representação indígena) revestiu-se de uma significação tão totalizadora, que a partir desse momento os Bororo renunciaram a toda e qualquer agressividade natural, castrando- se simbolicamente, a ponto de ficarem exageradamente passivos e dependentes. Viertler (2000), antropóloga com vasto conhecimento a respeito da cultura bororo, comenta que este modus operandi gera constantamente um sentimento de mal-estar entre aqueles que com eles interagem buscando auxiliálos no caminho da autodeterminação e autogestão.

Os Bororo, de índole pacífica, com o 'amansamento' pelo qual se convertem exatamente no que o civilizador queria, ficaram patologicamente passivos, dependentes, sem autoafirmação, nem autoestima, sem a defesa mínima da própria personalidade, e sem o impulso básico de conseguir suas próprias coisas, satisfazer suas necessidades, exigindo tudo do branco e se desapontando continuamente.

E aí temos outra função do álcool para a personalidade bororo atual: por meio dele, recupera-se a força perdida, a agressividade para a defesa (ou a vingança). São inúmeros os testemunhos de que Bororo bebe para 'ganhar coragem', pois a expressão 'falta de coragem' abrange tudo o que queremos dar a entender como a repressão de toda agressividade.

Diante de rixas, recuam, recolhem-se, guardam as ofensas por anos e anos, só com álcool têm coragem para revidar. (Cleonice, enfermeira da Unidade de Saúde Indígena da Funai de Cuiabá, Mato Grosso do Sul)

Os Bororo antes eram valentes e altivos e perderam tudo isso: agora bebem álcool como uma droga para ter coragem para fazer o que planejam. (Valdomiro, chefe de posto da Funai de Meruri, Mato Grosso do Sul)

Não é possível - nem é o objetivo deste texto - desenvolver aqui as implicações teóricas do mecanismo psíquico da repressão maciça da agressividade, especialmente a partir do campo da cultura e personalidade (Whiting, 1965), tarefa 
promissora para pesquisas futuras e que abre uma interessante compreensão do fenômeno do alcoolismo entre os Bororo.

O que podemos adiantar é que, com esse conceito, enfocado do ponto de vista etnopsicológico, não só é possível comparar esta nação com outras que têm um padrão similar de alcoolismo (Hallowell, 1955), como entender as explosões periódicas e a sabotagem passiva.

Quando se reprime qualquer tipo de impulso, este, além de se deformar nas situações cotidianas, explode sem controle, manifestando-se com toda sua força de tempos em tempos (Quiles, 1986). No caso da agressividade bororo, a original defensiva, seguida pelos desapontamentos, explode em bebedeiras que acabam quase sempre violentamente, forma essa a qual categorizamos, anteriormente, como 'dipsomaníaca' ou 'alcoolismo explosivo'.

A deformação mais sub-reptícia está na forma de sabotagem passiva, encoberta, muitas vezes relacionada aos comportamentos alcoolistas como comentamos anteriormente, estando associada a uma intenção implícita de assustar, provocar, e mesmo desconcertar nas relações interétnicas. Viertler (2000) propõe que o modo contemporâneo dos Bororo consumirem bebidas alcoólicas deve ser compreendido como uma espécie de adaptação à nova ordem imposta pelo assimétrico contato interétnico, e até mesmo como um tipo de resistência cultural levada às últimas consequências. Assim, o consumo de bebidas alcoólicas pelos Bororo constitui-se em um grande desafio a ser enfretanto pelos diferentes agentes do contato com os quais eles interagem.

Não queremos com este texto esgotar a análise do problema em foco; fazemos nosso o ponto de vista da etnopsiquiatria de que qualquer manifestação humana considera-se sobredeterminada, no sentido freudiano de muitas motivações, muitas causas para um mesmo comportamento, e essa causalidade multidisciplinar encontra-se sempre em relação complementar (Devereux, 1972).

Notas

1 Este capítulo é uma versão revista de: Quiles, M. 'Mansidão de fogo': aspectos etnopsicológicos do comportamento alcoólico entre os Bororo. In: SEMINÁRIO SOBRE ALCOOLISMO E DST/ AIDS ENTRE OS POVOS INDÍGENAS. Brasília: Coordenação Nacional de DST e AIDS, Secretaria de Políticas de Saúde, Ministério da Saúde, 2001. Texto republicado com autorização do autor.

2 Comunicação pessoal de um velho Bororo, em 1996, ao irmão salesiano Mário Bordignon da Missão de Meruri, prestigiado historiador ítalo-brasileiro que mora há décadas entre os Bororo.

3 Essa informante é uma indígena, da etnia Paresi, e enfermeira da Unidade de Saúde Indígena da Funai de Cuiabá. Ela foi casada com Bororo e morou muitos anos, por motivos de trabalho, na aldeia de Perigara, no Pantanal. A entrevista que nos concedeu reveste-se de um valor muito especial, dado o seu ponto de vista indígena, não Bororo, e pelo fato de ser conhecedora profunda dos seus costumes. 


\section{Referências}

ALBISETTI, C. G VENTURELli, A. J. Enciclopédia Bororo. v. I. Campo Grande: Museu Regional Dom Bosco, 1962.

BERGER, P. L. G LUCKMANN, T. A Construção Social da Realidade. Petrópolis: Vozes, 1974.

BORDIGNON, M. E. Os Bororo na História do Centro-Oeste Brasileiro. Campo Grande: Missão Salesiana de Mato Grosso, 1986.

BORDIGNON, M. E. O Alcoolismo e o Povo Indígena Bororo. Meruri, 1996. (Mimeo.)

CALDAS, J. A. Memória Histórica sobre os Indígenas da Prov. de Matto Grosso. Rio de Janeiro: Typ. Polythechnica de Moraes e Filhos, 1887.

DEVEREUX, G. Etnopsicoanálisis Complementarista. Buenos Aires: Amorrortu Editores, 1972.

EY, H.; BERNARD, P. G BRISSET, C. H. Tratado de Psiquiatría. Barcelona: Toray Masson, 1974.

FLORENCE, H. Viagens do Tietê ao Amazonas. São Paulo: Cultrix, EdUSP, 1977.

HALLOWELL, I. Culture and Experience. Philadelphia: University of Pennsylvania Press, 1955.

QUILES, M. I. Neuroses. São Paulo: Ática, 1986.

SIMONIAN, L. T. L. Alcoolismo entre Indígenas: abordagens, contextos e perspectivas. In: $1^{\circ}$ OFINA MACRORREGIONAL DE ESTRATÉGIA, PREVENÇÃO E CONTROLE DAS DSTS/AIDS PARA AS POPULAÇÕES INDÍGENAS DAS REGIÕES SUL, SUDESTE E DO MATO GROSSO DO SUL, Londrina. Anais... Londrina: Programa Nacional de DST/AIDS; Programa Municipal DST/AIDS, 1997.

STEINEN, K. V. D. Entre os Aborígenes do Brasil Central. São Paulo: Departamento de Cultura, 1940.

VIERTLER, R. B. A Duras Penas. São Paulo: FFLCH, USP, 1990.

VIERTLER, R. B. Alcoolismo entre os Bororo. In: CANESQUI, A. M. (Org.). Ciências Sociais e Saúde para o Ensino Médico. São Paulo: Hucitec, 2000.

WADDELL, J. G EVERETT, M. Drinking Behavior among Southwestern Indians: an anthropological perspective. Tucson: University of Arizona Press, 1980.

WHITING J. W. O complexo de frustração na sociedade kwoma. In: CLUCKHONH, C. G MURRAY, H. (Orgs.). Personalidade: na natureza, na sociedade e na cultura. Belo Horizonte: Itatiaia, 1965. 


\section{Quando, como e o que se Bebe: o processo de alcoolização entre povos indígenas do Alto Rio Negro, Brasil ${ }^{1}$}

Maximiliano Loiola Ponte de Souza e Luiza Garnelo

Uma das principais colaborações da antropologia, ao tomar como objeto de estudo a questão do uso de bebidas alcoólicas, foi demonstrar a variabilidade cultural das formas de beber (Heath, 1984), permitindo o questionamento de conceitos, modelos e teorias que interpretam o fenômeno como um invariante universal (Heath, 1993).

Um dos conceitos criticados é o de alcoolismo, sobretudo quando entendido como uma doença crônica, fatal, progressiva e com apresentação similar em qualquer contexto social (Kunitz G Levy, 1994). Ao restringir as pesquisas à dimensão do alcoolismo-doença, deixa-se de explorar outros aspectos importantes relacionados ao uso de álcool.

Menéndez (1982) aponta a necessidade de se investigar o papel do consumo de álcool em culturas específicas. Para isso, o autor propõe o conceito de alcoolização, que seria,

o conjunto de funções e consequências positivas e negativas que cumpre a ingesta de álcool para conjuntos sociais estratificados, e não apenas o estudo dos alcoólicos dependentes, nem os excessivos, nem os moderados, nem os abstêmios, mas sim o processo que inclui a todos e que evita considerar o problema em termos de saúde e/ou enfermidade mental. (Menéndez, 1982: 63)

Tal conceito gera a necessidade de contextualizar o uso de álcool, na cultura e na história, e não apenas o uso problemático. Em última análise, busca o significado que o beber assume para um dado grupo social, em um determinado tempo.

Investigando essa temática entre povos indígenas, Langdon (2001: 86) acentua a ideia de variabilidade, ao afirmar que, "a maneira de beber, como beber e quanto beber nas culturas indígenas têm sido definidos pela etnia específica, e o consumo de bebidas fermentadas é uma manifestação das atividades constitutivas para o grupo social, expressando sensações e valores particulares". 
O objetivo deste capítulo é analisar o processo de alcoolização entre povos indígenas do Alto Rio Negro, noroeste amazônico, demonstrando a inter-relação entre o contexto sociocultural local, a história das relações interétnicas e os modos de consumo de bebidas alcoólicas. A pesquisa se preocupou com o que se bebe, como se bebe e quando se bebe (Langdon, 2001), efetuando uma abordagem interessada em apreender as modificações e ressignificações associadas ao beber, do ponto de vista nativo.

\section{Contexto cultural}

O Alto Rio Negro é habitado por indígenas pertencentes aos troncos linguísticos Tukáno, Aruák e Makú. Embora existam diferenças entre eles, compartilham "o cultivo da mandioca amarga; o consumo de caxiri (bebida alcoólica produzida da mandioca); as festas de trocas (dabucuris) e os rituais de iniciação masculina com o uso de flautas sagradas" (Buchillet, 1990: 5).

As atividades rituais habitualmente estão associadas ao consumo de bebidas alcoólicas. Na cosmologia desses grupos, a origem do mundo está ligada ao consumo de caxiri e de tabaco pelos deuses primordiais. A literatura etnológica sobre a região atesta a ampla associação entre o consumo de bebidas alcoólicas, o acesso a estados alterados de consciência, o contato com o sagrado e a reprodução dessas sociedades (Jackson, 1983; Reichel-Dalmatoff, 1986; Buchillet, 1990).

A confecção do caxiri é uma atividade feminina cujo preparo leva de dois a três dias (Jackson, 1983). Tradicionalmente é consumido coletivamente nas festas de troca, que permitem o estreitamento de alianças políticas e matrimoniais entre os diferentes grupos e o intercâmbio de gêneros alimentícios em um ambiente carente de recursos (Chernela, 1993). Igualmente a bebida costuma ser ingerida durante a realização de trabalhos coletivos, nos quais os laços de solidariedade e obrigações mútuas são reforçados. Tanto atualmente, quanto em tempos passados, as festas duram dias e somente terminam quando a bebida se esgota.

O contato interétnico, iniciado há mais de três séculos, propiciou a introdução da cachaça, que foi ativamente utilizada pelos colonizadores como meio de escravização (Oliveira, 1995). Além da cachaça, outras substâncias, como o álcool de farmácia, desodorante e perfume passaram a ser ingeridos. Outra situação associada ao contato foi a introdução da educação formal pelos missionários. A implantação de escolas nos povoados trouxe importantes mudanças na organização dessas sociedades indígenas, tais como a concentração das famílias, antes dispersas, em locais próximos às aldeias com escolas. Tal mudança parece se associar ao incremento das situações em que se bebe, visto que amplia a quantidade de trabalhos coletivos e das festas e favorece a mobilidade social, em contraste com as tradicionais relações de hierarquia que ancestralmente regem o ethos rionegrino. 


\section{Metodologia}

O recorte etnográfico deste estudo pauta-se pela abordagem interpretativa de Geertz $(1989,2002)$. Esse autor propõe a existência de uma íntima interação entre cultura e organização social e define a cultura como um padrão de significados, produzidos e transformados historicamente pelos homens, emergindo da interação social e variando segundo o contexto em que são engendrados. A noção de cultura como um sistema fluido e aberto à reinterpretação, subsidiou o desenho da pesquisa, conduzindo à ideia de que os sentidos atribuídos ao beber só poderiam ser apreendidos pelo entendimento das condições ancestrais e atuais da vida indígena e de suas mudanças, produzidas por sujeitos que partilham uma teia específica de significados. Subsidiariamente as contribuições de Langdon (2001), Menéndez (1982) e da literatura etnológica sobre o Alto Rio Negro (Jackson, 1983; ReichelDalmatoff, 1986; Buchillet, 1990; Chernela, 1993; Oliveira, 1995) também moldaram as estratégias de coleta e análise dos dados.

Os dados deste trabalho fazem parte de um projeto de pesquisa mais amplo, que investiga as relações entre saúde, cultura e condições de vida dos povos indígenas. Os autores têm uma história prévia de interação com esses grupos, que abrange, no caso da autora, um período de 17 anos. Os dados de campo que tratam do tema específico da alcoolização foram coletados em três aldeias diferentes, cujos nomes são omitidos para se evitar a estigmatização dos indígenas que lá residem. As aldeias foram selecionadas por apresentarem condições favoráveis à pesquisa, tais como o bilinguismo (português e tukáno); a coabitação de vários grupos étnicos agrupados em torno das escolas e das igrejas; o difícil acesso; a longa distância do centro urbano mais próximo (São Gabriel da Cachoeira) e o fácil contato com comerciantes, os fornecedores privilegiados de bebidas alcoólicas industrializadas. Além disso, ainda que não existam dados epidemiológicos prévios sobre a magnitude do problema do uso abusivo do álcool no Alto Rio Negro, esses assentamentos são reconhecidos pelos agentes políticos indígenas como locais em que a alcoolização é intensa, frequente, violenta e prejudica o desenvolvimento de atividades rotineiras de subsistência.

A complexidade do objeto exigiu a associação de técnicas de pesquisa (Minayo, 2004; Deslandes G Gomes, 2004), tais como a observação participante, a coleta de entrevistas semiestruturadas, de entrevistas em profundidade e a realização de grupos focais com jovens de 14 a 18 anos. 


\section{Resultados e discussão}

\section{$\mathrm{O}$ que se bebe e como se bebe}

Nos locais pesquisados, o caxiri permanece sendo a bebida mais consumida. Seu preparo atual difere da forma como era ancestralmente produzido, pois a indução da fermentação pela saliva das mulheres foi substituída pelo acréscimo de açúcar e aquecimento ao fogo. Segundo os informantes, essa forma de preparação produz uma bebida com maior teor alcoólico.

Tal como ocorre entre outras culturas indígenas (Kunitz G Levy, 1994), uma vez preparado, o caxiri é consumido até o seu término, e esse é o principal mecanismo regulador da quantidade de bebida ingerida. Caso a bebida preparada não seja ingerida no mesmo dia, ela o será na manhã seguinte, não se praticando a estocagem da mesma.

A cachaça aparece como a segunda bebida mais consumida. Outras bebidas contendo álcool são utilizadas, tais como o álcool de farmácia, desodorante e perfume, entretanto, o seu consumo é visto como inadequado pela população.

A lógica de consumo do caxiri até o seu término foi transposta para a cachaça: "bebe até terminar a grade [de cachaça]. E não querem parar mesmo não. Sempre vão tomando; continua tomando mesmo no dia seguinte. Até terminar a grade. Aí, só quando terminam as grades, eles começam a parar" (masculino, Tukáno, 35 anos).

Ao se discutir o uso da cachaça, era comum ouvir os entrevistados dizerem que desde o início da colonização a bebida foi trazida pelos brancos que navegavam pelos rios da região. Ilustrativo desse fato é o relato de como, pela primeira vez, um indígena fez uso dessa bebida em uma das aldeias investigadas, na década de 1960.

Falaram que o comerciante ia passar aquele barco grande, para cima da cachoeira. Ele convidou todo o pessoal para ajudar. Então chegamos lá no fim da cachoeira, então ele disse: 'olha, quem quer bolacha, faz fila aqui; quem quer bombom, faz fila aqui; agora, quem quer cachaça, faça fila aqui'. Eu fui fazer fila na de bebida, sabe. Doido para experimentar o que era. Ele dava dois pacotes de bolacha; para os outros, bombons, e para nós, um pouco de cachaça. Aí ele disse: 'quem quer mais, faz fila de novo'. Ele passou lá em cima, depois voltou, e já marcou a data que já ia passar por aí de novo. Aí, a gente esperava. (masculino, Desáno, 60 anos)

A narrativa desse informante atesta uma prática que se perpetua em tempos mais recentes. A cachaça antes utilizada como meio de subjugação e aliciamento para o trabalho forçado (Oliveira, 1995), passa a ser uma das moedas de troca de trabalho indígena por produtos manufaturados, hoje imprescindíveis à sua subsistência. 
Embora a cachaça tenha sua entrada nas áreas indígenas proibida pelo Estatuto do Índio (Brasil, 1973), isto não impede a circulação clandestina, ainda que por preços exorbitantes. Se, na sede do município de São Gabriel da Cachoeira, a garrafa de $600 \mathrm{ml}$ pode ser comprada por três reais, nas aldeias ela adquire valores superiores a vinte reais, tornando seu consumo um símbolo de prestígio e um objeto de desejo. "Hoje é status beber cachaça porque você vai comprar uma bebida de vinte, trinta, quarenta, cinquenta reais à noite" (masculino, Tukáno, 49 anos).

A aquisição da bebida pode ser feita em dinheiro vivo, ou, em menor escala, trocada por farinha, peixe ou gêneros da floresta. Em consequência, as pessoas com trabalho remunerado (professores, agentes de saúde, aposentados e militares indígenas) são as que têm maior acesso, embora seu consumo não se restrinja aos compradores. Sendo um produto associado ao prestígio, os que adquirem a bebida são pressionados a partilhá-la com os demais, demonstrando generosidade e inserindo o consumo de bebida alcoólica no grande conjunto de relações de reciprocidade que fundamentam o modo de viver indígena.

\section{Início do consumo de bebidas alcoólicas}

O início do uso de caxiri deve ser correlacionado ao tipo de caxiri: fraco ou forte. O primeiro, com baixa fermentação e fraco teor alcoólico, não é considerado propriamente uma bebida, mas um alimento consumido a partir da primeira infância (três ou quatro anos). Tal prática não é exclusiva dos índios rionegrinos, sendo compartilhada pelos Kaxináwa, Yamináwa, Kulína e Kaingang (Oliveira, 2003). Segundo os informantes do sexo masculino com mais de 40 anos, o início do consumo se dava por volta dos 12 a 15 anos. O uso nessa faixa etária estava ligado ao ritual de iniciação masculina (Reichel-Dalmatoff, 1986), atualmente em desuso em diversas áreas da região (Andrello, 2006). As rememorações dos informantes indicam que a idade de início de uso vem caindo sensivelmente nos últimos anos.

Entre as mulheres com mais de 40 anos, o início do consumo se dava, em geral, após os 20 anos, posteriormente ao casamento. Tal comportamento não foi observado entre as informantes jovens, que relatam início de uso mais precoce, assemelhando-se ao padrão masculino atual.

O início do consumo da cachaça, entre aqueles com mais de 40 anos, independentemente do sexo, ocorria após os 20 anos, ou seja, bastante tempo depois do começo do uso de caxiri. Nos tempos atuais, os mais jovens (menos de 20 anos), de ambos os sexos, relatam ter iniciado o uso de cachaça concomitantemente ao de caxiri, ou apenas pouco tempo depois.

O uso precoce de bebidas alcoólicas é atribuído pelos informantes ao incremento da movimentação de comerciantes não indígenas nas últimas décadas, 
mas a pesquisa mostrou que isto é apenas uma parte do problema, já que os 'brancos' não são mais os únicos fornecedores de bebida. $\mathrm{O}$ aumento da navegação dos próprios indígenas e uma crescente relação com o meio urbano ampliaram a possibilidade de compra em São Gabriel da Cachoeira. Diversos motivos propiciam a ida à cidade, tais como receber aposentadoria ou salário, comprar mantimentos e visitar parentes ou filhos que lá estudam, potencializando um acesso cotidiano à bebida.

Outra importante mudança no modo de vida está ligada à implantação dos internatos salesianos, entre as décadas de 1950 a 1970, que empreenderam um deliberado esvaziamento da autoridade dos mais velhos sobre os mais novos (Foirn, 2000), seja pela redução do contato intergeracional, seja pela coibição dos ritos de passagem, que representavam uma importante via de internalização dos valores éticos do grupo. Em decorrência, fragilizaram-se importantes formas de reprodução do acervo cultural, aí se incluindo estratégias de controle de uma geração sobre a outra. A substituição dessas formas de socialização pelas escolas, pouco ou nada, veio contribuir para a preservação de uma ordem social fundada, em grande medida, na hierarquia das classes de idade.

Embora as escolas das três aldeias não funcionem em regime de internato desde o final da década de 1980 (Foirn, 2000), os estudantes indígenas permanecem distantes de suas famílias, já que muitos pais continuam residindo na localidade de origem e os filhos se deslocam para estudar nos centros missionários, ali ficando aos cuidados de parentes. Muito cedo os jovens ficam expostos à violência e à sedução do contato interétnico e, em consequência, a influência das famílias sobre seu comportamento moral fica reduzida às episódicas visitas dos pais ou ao período de férias, quando os jovens retornam para casa. Durante a pesquisa foi possível registrar relatos sobre a embriaguez de garotas menores de 15 anos, aliciadas por comerciantes não indígenas, que após usarem-nas sexualmente as deixaram desacordadas e abandonadas ao relento. Situações como essa são mais frequentes no caso de estudantes cujas famílias moram em locais distantes da escola.

Para evitar tais problemas, muitas famílias, ou parte delas, deixam suas aldeias para viver no centro missionário na época das aulas. Essa situação acarreta novas consequências negativas, tais como a dificuldade em manter a roça e a pesca para alimentação da família. Geram, ainda, a ruptura das relações de cooperação com os corresidentes do assentamento de origem e interações potencialmente conflitivas entre os habitantes originais da localidade e os visitantes semipermanentes, cuja presença provoca disputas por prestígio e bens de subsistência.

Em resumo, os dados mostram que o uso precoce de cachaça pelos jovens está associado, por um lado, a um aumento da oferta e circulação da bebida nas aldeias, e por outro, à dinâmica das relações internas do grupo. O conjunto dessas interações promoveu uma mudança das formas tradicionais de assentamento e de 
socialização dos jovens, o desgaste da autoridade moral dos velhos e uma impotência das famílias em controlar o uso precoce e abusivo de bebidas alcoólicas industrializadas. Essa interpretação foi corroborada pelos jovens participantes dos grupos focais realizados na pesquisa, que atribuem sua não adesão aos conselhos dos pais, que solicitam moderação no uso de bebidas, a uma fraca autoridade moral de adultos que fazem um uso igualmente abusivo de álcool.

Além disso, os participantes estabelecem uma valoração privilegiada aos "conselhos de antigamente", que eram oferecidos de forma ritualística, com apoio da fumaça de cigarro, permitindo que a orientação "entrasse na cabeça e não saísse". Atualmente essa estratégia teria perdido a eficácia, pois sem o rito propiciatório, "a cabeça fica fechada e os conselhos não entram". Em outras palavras, uma vez abolidos os ritos pubertários, aparentemente não se produziram outras estratégias similarmente eficientes para viabilizar o controle do uso de álcool.

Concomitantemente ao desgaste da autoridade dos mais velhos, observase ainda uma reorganização dos critérios definidores de prestígio, antes associados às hierarquias clânicas e de geração. Os dados obtidos junto aos jovens mostram que uma de suas principais aspirações é "ter uma vida diferente da dos pais", significando, dentre outras coisas, o desejo de se afastarem da produção agrícola e de se tornarem trabalhadores assalariados. A baixa escolaridade, o pouco domínio do português e a inacessibilidade ao trabalho assalariado tornam os mais velhos um exemplo a não ser seguido. $\mathrm{O}$ acesso à educação formal e ao dinheiro passou a representar importantes objetivos a serem perseguidos, atribuindo-se uma importância menor às fontes tradicionais de prestígio.

As tensões ligadas às disputas por formas novas e velhas de prestígio se expressaram com clareza em situações de embriaguez que se associaram à violência física. Em uma das situações observadas, o conflito instalou-se entre personagens que, pertencentes a clãs desprestigiados, mas detentores de empregos assalariados e de boa escolaridade, eram hostilizados por outros indígenas que ocupavam lugares mais prestigiosos na hierarquia ritual tradicional, mas não desfrutavam de um bom acesso às benesses do mundo não indígena. Da mesma forma, jovens indígenas engajados nas Forças Armadas, que disputam com vantagem sobre os outros homens os favores sexuais das mulheres disponíveis nas aldeias, tornaram-se objeto de hostilidade dos habitantes da localidade. Pelo menos, um caso de séria agressão física pôde ser registrado, num evento em que um militar indígena foi espancado por jovens consanguíneos, sob as vistas e com o estímulo dos mais velhos.

\section{Quando se bebe}

Os momentos mais comuns de uso de bebidas alcoólicas são as situações de consumo coletivo, tal como ocorre durante as festas e os trabalhos comunais momentos reconhecidos como culturalmente adequados, segundo a visão nativa. 
Em tempos anteriores, essas situações se restringiam aos contextos rituais específicos e espaçados, porém, as mudanças trazidas pelo contato interétnico introduziram, além dos dabucuris, outras festas no calendário indígena.

A pesquisa identificou 22 datas comemorativas distribuídas ao longo do ano. Destas, 11 estão associadas à Igreja Católica, como as festas de santo. Todas as comunidades possuem seu santo padroeiro; se uma comunidade grande é subdividida em vilas, cada vila terá seu próprio padroeiro, multiplicando-se, assim, as festas. Outras cinco festas estão associadas às datas do calendário cívico nacional e duas a comemorações escolares. Em cada uma dessas ocasiões o uso de bebida é considerado um comportamento lícito e aceitável. Além dos momentos citados, os informantes referem a existência de outras situações festivas, recentemente introduzidas, tais como os casamentos, batizados e aniversários.

A outra ocasião de consumo grupal de bebidas alcoólicas se dá durante os trabalhos coletivos. Estes podem ser divididos em duas categorias principais: os ajuris (realizados por todos, mas no interesse de uma família em particular) e os chamados trabalhos comunitários (realizados pelo grupo, no interesse da coletividade). Tal divisão é relevante nesta análise visto que são contextos de uso de bebidas, nos quais os mecanismos envolvidos no recrutamento para o trabalho são diferenciados, embora tendo ambos implicações na forma de consumo de bebidas alcoólicas.

A chave do entendimento da primeira modalidade de trabalho coletivo remete às antigas malocas, cuja coabitação preferencial se dava entre consanguíneos, que compartilhavam fortes sentimentos de pertença, associados entre si por laços de solidariedade e reciprocidade (Jackson, 1983; Reichel-Dalmatoff, 1986; Chernela, 1993; Oliveira, 1995). Embora as malocas também comportassem comensais não parentes, essa presença era regulada por acordos e obrigações mútuas entre os moradores, incluindo-se o auxílio na realização de trabalhos cotidianos. Após a extinção da maloca, a oferta de comida e bebida persistiu entre os residentes de uma mesma aldeia ou vizinhos próximos, operando como uma retribuição do grupo beneficiado aos demais participantes do trabalho (Oliveira, 1995). Um velho resumiu esse mecanismo da seguinte forma: "Eu preparo o caxiri aqui, aí eu convido meus filhos, meu tio, meu sobrinho, meu neto, meu cunhado, esses são assim parentes para mim. Porque o campo é grande. Aí eu não posso roçar sozinho" (masculino, Tukáno, 73 anos).

Porém, nos povoados que se formaram em torno das missões ocorreu uma mudança no padrão de assentamento - e em consequência, nas obrigações mútuas -, incentivando-se a corresidência de não parentes. Nos dias de hoje não é incomum que rivais e desafetos passem a habitar na mesma localidade. Na organização atual do ajuri, a oferta de bebidas substitui, em parte, a motivação 
decorrente dos antigos laços de solidariedade entre parentes, como se pode apreender do discurso do citado informante.

Porque antigamente, às vezes trabalhava para o parente, só por farinhazinha, comida. Era parente. (...) Agora não. (...) Quando não tem caxiri, quase não vai não. Vão três, cinco. Agora quando tem, pronto! Todo mundo quer tomar; aí vai embora, rapazes, velho, moças, mulher às vezes (masculino, Tukáno, 73 anos)

Assim, a bebida vem se tornando a principal forma de retribuição pelo trabalho comunal, inflada artificialmente pelos novos padrões de assentamento que divergem da clássica patrilocalidade rionegrina.

Entretanto, houve um incremento das situações em que se promove ajuri, estando tal fato associado à existência de indígenas cuja atividade principal é remunerada (professores, por exemplo). Por indisponibilidade de tempo para o trabalho na roça, esses assalariados tendem a promover os ajuris com frequência. Soma-se a isso o alto prestígio auferido pelos donos de grandes roças, gerando a paradoxal situação em que os assalariados, com status mais alto e com menos tempo para o trabalho agrícola, são os que tendem a ter uma maior quantidade de roças. É uma situação que demanda um alto investimento na promoção de ajuris e, consequentemente, uma maior distribuição de bebida alcoólica.

Já os trabalhos comunitários podem ser realizados com vários propósitos. Outrora, a construção de uma maloca ou a manutenção das armadilhas de pesca demandavam uma negociação delicada envolvendo o líder da aldeia e os demais indígenas, visto que as chefias locais não tinham (como ainda hoje não têm) poder de mando sobre os demais membros do grupo (Jackson, 1983). O tuxaua exercia a chefia em bases de prestígio, fundado na sua posição na hierarquia ritual, no acesso privilegiado aos recursos pesqueiros e na generosa distribuição dos bens por ele auferidos (Chernela, 1993).

Esse sistema de chefatura foi alterado com a ação salesiana que fragmentou as atribuições dos chefes e manipulou a escolha de lideranças segundo critérios que favorecessem o poder missionário (Jackson, 1983; Chernela, 1993). As novas chefias não detêm as prerrogativas do antigo líder, entretanto, continuam a precisar do trabalho coletivo dos demais, para manter certas atividades necessárias à sobrevivência de todos. Também é fato que houve um incremento das situações que exigem a realização desses trabalhos. Na atualidade, os trabalhos comunitários são rotineiramente promovidos para executar políticas públicas que não se interiorizam nas aldeias, tais como a reforma da escola, a limpeza da comunidade, a instalação de rede elétrica e outras.

Nesse contexto de frágil legitimidade política, a oferta de bebida alcoólica pela liderança surge como um elemento fundamental para a adesão do grupo aos 
trabalhos comunitários. A associação entre trabalho comunitário e consumo de bebida é criticada por aqueles que discordam que a liderança lance mão da bebida para mobilizar a comunidade.

Eu estou vendo assim, aqui na aldeia tem capitão que costuma, no dia de comunidade, fazer roça grande. Ele costuma mandar preparar caxiri. Todo mundo junto: pronto, vamos plantar. O chefe é que está estragando, prepara todo tempo caxiri. Porque antigamente não era assim. (masculino, Tukáno, 73 anos)

O informante se referia a um trabalho coletivo, que tinha por objetivo a preparação de uma grande roça comunitária destinada às pessoas que não residiam na aldeia, mas que lá permaneceriam parte do ano para acompanhar os filhos na escola. Tal trabalho difere do que costuma ser chamado de ajuri, pois não era um trabalho coletivo promovido por uma família específica, com a colaboração dos demais. Também não era um trabalho comunitário, visto que não seriam beneficiados todos os membros da comunidade. Essa roça coletiva é uma inovação trazida pela escolarização massiva, congregando o esforço de pessoas com frouxos laços entre si. Conforme se previu, sua realização só foi viabilizada por meio de grande oferta e consumo de caxiri.

Como já assinalado, o consumo de álcool não se dá exclusivamente nas situações de festas e de trabalhos coletivos. Em uma das aldeias, o uso de álcool fora do contexto coletivo é incrementado pela atividade constante de barcos de comércio. Durante a pesquisa observamos o recrutamento de jovens para realizar o carregamento e transporte de mercadorias para transpor a grande cachoeira que existe no local. Esse recrutamento, realizado por comerciante não indígena, foi feito de modo individualizado, sem a menor interferência do capitão da comunidade. A cachaça foi o estímulo para o recrutamento e a forma de pagamento do trabalho. O consumo subsequente foi meramente recreativo, microgrupal, restrito aos jovens trabalhadores, e não no ambiente coletivo ligado aos rituais de reprodução da sociedade. Em circunstâncias como essa, observa-se mais comumente o uso de substâncias consideradas como impróprias para o consumo, como álcool de farmácia, desodorante ou perfume.

Em situação similar, noutra localidade investigada, uma sala da escola foi arrombada e uma garrafa de álcool foi roubada. De acordo com uma informante, "ao terminar a festa, às vezes, os jovens procuram até acharem álcool por aí e fazem batida" (feminino, Desáno, 22 anos).

O antigo hábito de beber, até que se acabe o estoque de bebida, permanece. Antigamente esse costume operava como regulador do consumo abusivo, pois limitava a bebedeira à quantidade de bebida disponível, obrigando a uma pausa até um novo momento ritual. Tal forma de controle está sendo inviabilizada 
pela presença constante de substâncias alcoólicas, no dia a dia das comunidades. Assim, o término do caxiri não demarca mais o encerramento do consumo, mas, ao contrário, pode desencadear uma frenética procura por álcool, de qualquer espécie, para dar continuidade a um consumo, agora microgrupal.

\section{Sobre permanências e mudanças}

O cenário encontrado pode ser descrito como fruto de permanências e mudanças simbólicas e materiais dessas sociedades, geradas ao longo de três séculos de contato com a sociedade nacional. Os símbolos e significados que expressam o processo de alcoolização descrito indicam que, nos locais estudados, os recursos tradicionais de ordenação da vida indígena parecem estar em xeque, enfrentando dificuldades em exprimir a experiência social atual e oferecer parâmetros de ação para as gerações mais jovens, que demandam novas formas de orientação de comportamentos e de valores no mundo contemporâneo.

Os quase sessenta anos de abolição dos ritos de passagem parecem cobrar seu preço, propiciando a contestação da estrutura hierárquica tradicional que regulava minuciosamente as interações entre os diferentes nichos sociais e minimizava conflitos e violência entre gerações. Mudanças trazidas pela escolarização e assalariamento, pelo domínio da língua portuguesa e da etiqueta política que hoje rege o exercício da etnicidade, geraram um tipo de protagonismo político indígena que é exercido por meio de competências técnicas, políticas e econômicas, distintas dos laços de parentesco, que outrora regiam o sistema de prestígio frátrico e os comportamentos chancelados pelo grupo. A busca de modos urbanos de vida e o afastamento deliberado dos comportamentos e da moral tradicional parecem contribuir para uma carência de parâmetros de orientação do comportamento das novas gerações em relação ao consumo de álcool.

As informações geradas pela investigação não podem ser extrapoladas para o conjunto de sociedades rionegrinas, mas para os locais pesquisados consideramos que a alcoolização abusiva expressa um mal-estar ligado a uma indefinição sobre o modo adequado de conduzir a socialização das novas gerações. Os dados também sugerem a existência de um processo, ainda pouco delineado, de construção de novas formas de socialização. Em seu processo de consolidação, elas deixam o caminho aberto para a ambiguidade e a violência, antes obscurecidas pela ritualização da hierarquia.

As alterações no consumo de álcool foram marcadas pelas mudanças na forma de preparo da bebida, pelo incremento das situações consideradas adequadas para beber e, principalmente, pelas mudanças no contexto histórico. Diante delas, o grupo lançou mão de regras de conduta previamente existentes, redimensionandoas e ressignificando-as para fazer frente às novas realidades que se lhe apresentavam. 
Se, por um lado, o grupo incorporou as mudanças de contexto adotando novas atitudes, até o momento atual parecem não ter forjado meios eficientes de regulação do uso de álcool no mundo contemporâneo. A principal estratégia de limitação do consumo permanece sendo a não disponibilidade da bebida; porém, o uso desse controle externo para limitar o embebedamento se mostra incapaz de produzir resultados eficientes, dados o incremento da movimentação indígena e o acesso a um número progressivamente maior de transportes eficientes e velozes.

Tornado um símbolo de status, que confere distinção àquele que a adquire e a redistribui, o uso da cachaça se integrou aos mecanismos tradicionais de generosidade e reciprocidade que regem a circulação dos bens, sendo limitado apenas pela indisponibilidade de recursos para adquiri-la. É algo que torna os assalariados, independente de sua posição na hierarquia tradicional, um alvo preferencial de críticas a um comportamento mesquinho - particularmente nos momentos de embriaguez coletiva, quando as acusações podem redundar em violência física -, e tende a incrementar a distribuição da bebida.

Outro elemento de mudança cultural que amalgama comportamento tradicional e influência do contato interétnico é a alcoolização do trabalho, ampliada pelo incremento das situações que exigem a mobilização coletiva para urbanizar aldeias cada vez maiores. Tal tarefa fica ainda mais dificultada pela progressiva fragmentação da autoridade das chefias locais. Nesse cenário, a oferta sistemática de bebida passou a operar como estratégia de recrutamento de mão de obra, não para atender aos patrões brancos, mas para reproduzir o modo atual de vida indígena.

Em conjunto essas reflexões corroboram a ideia da dinâmica da cultura, em que a dicotomia entre tradição e mudança não se sustenta. Assim, o processo de alcoolização deve ser aqui concebido como resultado da coexistência de normas sociais e padrões de ação antigos e contemporâneos. Ela modula a configuração dos contextos de uso do álcool e permite, de formas diversas, e frequentemente conflitivas, atribuir sentido aos desafios que se apresentam na existência desses povos, empenhados em constante reelaboração de seu viver cotidiano.

Sem ter a pretensão de extrapolar os achados rionegrinos para o complexo panorama das diversas sociedades indígenas que vivem no Brasil, consideramos que a situação ali encontrada permite refletir sobre os graves problemas hoje enfrentados pelas sociedades indígenas no tocante a essa questão. Nos locais investigados os dados mostraram que as antigas formas de regulação dos conflitos sociais não se mostram capazes de enfrentar as novas faces assumidas pelo consumo do álcool.

As únicas soluções até agora aventadas apontam para o incremento da fiscalização das embarcações pela Fundação Nacional do Índio (Funai). Em vigor há muitas décadas, essa medida repressiva não logrou qualquer eficácia para o controle 
do tráfico de bebidas alcoólicas. O problema se exacerba nos dias de hoje, em que há indígenas que desenvolvem atividades comerciais, entre as quais se inclui a venda de bebidas alcoólicas. Nesse caso, as medidas de fiscalização - concebidas com o pressuposto de que a movimentação de álcool nas terras indígenas seria produto exclusivo da ação dos não indígenas - teriam de incidir sobre as embarcações indígenas, ferindo seu direito inalienável de ir e vir em suas próprias terras, adicionando mais um componente de tensão nas relações entre os indígenas e o órgão indigenista, reduzindo quaisquer chances de sucesso.

No intrincado leque de interações que envolve o uso do álcool, podemos nos perguntar o que os indígenas pensam sobre o assunto, e que medidas proporiam para buscar soluções para o problema em seus próprios territórios. No caso rionegrino, o desconforto indígena é evidente e suas lideranças vêm discutindo o tema. Dentre as medidas já implantadas, situamos a pesquisa da qual resultou este capítulo, originalmente concebida para atender a uma demanda das associações indígenas locais, desejosas de entender as nuances do problema. Os produtos da pesquisa foram discutidos em assembleias indígenas, tendo as lideranças percebido que, longe de ser um problema médico, o consumo de álcool está a exigir uma reestruturação de suas próprias relações familiares, e um debruçar-se sobre os rumos que desejam imprimir ao futuro de suas gerações mais jovens. Ainda assim, no Alto Rio Negro, o debate permanece aberto, sem que se tenha, ainda, logrado um curso consensual de ação.

Nota

1 Este capítulo é uma versão de: Souza, M. L. P. G Garnelo, L. Quando, como e o que se bebe: o processo de alcoolização entre populações indígenas do Alto Rio Negro, Brasil. Cadernos de Saúde Pública, 23(7):1.640-1.648, 2007. Texto republicado com autorização dos autores e do editor da revista.

\section{Referências}

ANDRELLO, G. Cidade do Índio: transformações e cotidiano em Iauaretê. São Paulo: Unesp, ISA, 2006.

BRASIL. Lei n. 6.001 de 19 dez. 1973. Dispõe sobre o Estatuto do Índio. Diário Oficial da União, Brasília, 1973.

BUCHILLET, D. Los poderes del hablar: terapia y agresión chamánica entre los indios Desana del Vaupes brasileño. In: BASSO, E. G SHERZER, J. (Orgs.). Las Culturas Nativas Latinoamericanas a través de su Discurso. Quito: Abya-Yala/MCAL, 1990. 
CHERNELA, J. M. The Wanano Indians of the Brazilian Amazon: a sense of space. Austin: University of Texas Press, 1993.

DESLANDES, S. F. G GOMES, R. A pesquisa qualitativa nos serviços de saúde: notas teóricas. In: BOSI, M. L. M. G MERCADO, F. J. (Orgs.). Pesquisa Qualitativa de Serviços de Saúde. Petrópolis: Vozes, 2004.

GEERTZ, C. A Interpretação das Culturas. Rio de Janeiro: Livros Técnicos e Científicos, 1989.

GEERTZ, C. O Saber Local. 5. ed. Petrópolis: Vozes, 2002.

HEATH, D. B. Cross-cultural studies of alcohol use. Recent Developments in Alcoholism, 2: 405-415, 1984.

HEATH, D. B. Recent developments in alcoholism: anthropology. Recent Developments in Alcoholism, 11: 29-43, 1993.

FEDERAÇÃO DAS ORGANIZAÇÕES INDÍGENAS DO RIO NEGRO/INSTITUTO SOCIOAMBIENTAL (FOIRN). Povos Indígenas do Alto e Médio Rio Negro: uma introdução à diversidade cultural e ambiental do noroeste da Amazônia. 2. ed. São Gabriel da Cachoeira: Federação das Organizações Indígenas do Rio Negro, Instituto Socioambiental, 2000.

JACKSON, J. E. The Fish People: linguistic exomamy and Tukanoan identity in Northwest Amazon. Cambridge: Cambridge University Press, 1983.

KUNITZ, S. J. P. G LEVY, J. E. Drinking Careers: a twenty-five-year study of three Navajo populations. New Haven, London: Yale University Press, 1994.

LANGDON, E. J. O que beber, como beber e quando beber: o contexto sociocultural no alcoolismo entre as populações indígenas. In: SEMINÁRIO SOBRE ALCOOLISMO E DST/AIDS ENTRE OS POVOS INDÍGENAS. Brasília: Coordenação Nacional de DST e Aids, Secretaria de Políticas de Saúde, Ministério da Saúde, 2001.

MENÉNDEZ, E. L. El proceso de alcoholización: revisión crítica de la producción socioantropológica, histórica y biomédica en América Latina. Revista Centroamericana de Ciencias de la Salud, 22: 61-94, 1982.

MINAYO, M. C. S. O Desafio do Conhecimento: pesquisa qualitativa em saúde. 8. ed. São Paulo: Hucitec, 2004.

OLIVEIRA, A. G. O Mundo Transformado: um estudo da "cultura de fronteira" no Alto Rio Negro. Belém: Museu Paraense Emílio Goeldi, 1995.

OLIVEIRA, M. Uso de bebidas alcoólicas e alcoolismo entre os Kaingang da bacia do Rio Tibagi: uma proposta de intervenção. In: JEOLAS, L. S. G OLIVEIRA, M. (Orgs.). Anais do Seminário Cultura, Saúde e Doença. Londrina: Secretaria Municipal de Saúde de Londrina, 2003.

REICHEL-DALMATOFF, G. Desana: simbolismo de los indios Tukano del Vaupés. 2. ed. Bogotá: Procultura, 1986. 


\section{Modos de Vida e Modos de Beber de Jovens Indígenas em um Contexto de Transformações ${ }^{1}$}

Maximiliano Loiola Ponte de Souza, Suely Ferreira Deslandes e Luiza Garnelo

A região do Alto Rio Negro, localizada no Noroeste Amazônico, é habitada por cerca de 30.000 indígenas (Pagliaro, Azevedo G Santos, 2005), distribuídos em aproximadamente 22 etnias. Eles compartilham o uso do caxiri (bebida alcoólica fermentada à base de mandioca e frutas) (Jackson, 1983), que era consumido particularmente nas festas de troca ou dabucuris (Chernela, 1993) e nos rituais de iniciação masculina, situações de grande significado simbólico nesse contexto sociocultural (Hugh-Jones, C., 1979; Hugh-Jones, S., 1979). Nos mais de três séculos de contato interétnico, a cachaça também passou a ser consumida, as situações festivas foram incrementadas (Souza $G$ Garnelo, 2007) ${ }^{2}$ e, em diversos grupos, houve a supressão do rito pubertário (Lasmar, 2005; Andrello, 2006). Essa última transformação está associada, em parte, à introdução dos internatos pelos missionários salesianos. Enclausurados nessas instituições, criadas para catequizálos e transformá-los em agentes da civilização, os jovens não estavam em companhia dos mais velhos no momento em que deveriam ser iniciados (Andrello, 2006).

Iauaretê, distrito rural do município de São Gabriel da Cachoeira, é uma 'cidade' indígena (Andrello, 2006), localizada às margens do rio Uaupés, maior afluente do rio Negro. Ali foi implantado um internato que funcionou, nesse regime, de 1929 a 1986, quando foi transformado em externato. Desde então, famílias de diferentes locais e etnias passaram a migrar para Iauaretê para dar continuidade à escolarização dos filhos (Andrello, 2006), visto que nas pequenas comunidades não há oferta de ensino médio. Concomitantemente ao incremento demográfico, a localidade vem sendo urbanizada. Atualmente, dispõe de eletrificação, telefonia, comércio, quartel do exército e agência de correios que presta serviços bancários.

As mudanças nos padrões de moradia e hábitos dos indígenas residentes em Iauaretê a tornam um local prototípico para o estudo das relações entre modos de vida e o processo saúde-doença, objeto de interesse crescente no campo da saúde coletiva. Porém, os autores que abordam esse campo com as ferramentas da epidemiologia clássica não raramente reduzem os modos de vida a variáveis socioeconômicas e demográficas, agrupando-as em indicadores compostos. Estes 
se mostram pouco eficazes em apreender a multivariedade do real e incorporar dimensões subjetivo-valorativas e culturais (Castellanos, 1997; Almeida Filho, 2004), que são essenciais para a compreensão dos fatores que influenciam a produção da saúde e da doença (Contandriopoulos, 1998).

Apresenta-se aqui um estudo exploratório que investiga as dimensões qualitativas da vida social de Iauaretê, associadas ao consumo de bebidas alcoólicas pelos jovens indígenas, visto ali como socialmente problemático. Em Iauaretê, a afirmação corrente é que os jovens bebem cada vez mais cedo, de modo mais frequente e violento, e que há dificuldades coletivas em se lidar com esse comportamento.

O objetivo deste trabalho é analisar as possíveis interações entre as atuais condições de vida dos indígenas de Iauaretê e o modo de beber dos jovens indígenas, reconhecendo a intrínseca relação que se estabelece entre o contexto sociocultural, a organização social e as estratégias de enfrentamento, localmente disponíveis, para o problema.

\section{Pressupostos teóricos}

Almeida Filho (2004: 880) entende os modos de vida como o "conjunto articulado de práticas cotidianas", que pode ser decomposto em condições de vida e estilo de vida. As primeiras se referem às condições de produção e circulação de bens e serviços, de forma direta, ou via políticas públicas compensatórias. Já o segundo deve ser compreendido como o conjunto de comportamentos, hábitos e atitudes de indivíduos e grupos sociais.

Neste estudo, os jovens compõem o grupo social de interesse. A juventude é aqui entendida como "uma representação ou criação simbólica, fabricada pelos grupos sociais ou pelos próprios indivíduos tidos como jovens, para significar uma série de comportamentos e atitudes a eles atribuídos" (Groppo, 2000: 8). A conduta juvenil priorizada para análise é o consumo de bebidas alcoólicas. Analiticamente, o consumo de álcool pode ser decomposto em diferentes categorias. Entende-se por processo de alcoolização os modos e significados que o beber adquire em um grupo (Souza G Garnelo, 2007), em determinado contexto. Já os problemas relacionados ao uso do álcool relacionam-se a um modo de beber, tido socialmente como associado a efeitos adversos, sendo fortemente influenciado por condicionantes socioculturais e históricos (Edwards, Marshall G Cook, 1999; Souza G Garnelo, 2007).

Outro conceito-chave é o de espaço, entendido como a expressão geográfico-territorial de relações históricas, sociais, econômicas, culturais e ecológicas, travadas entre sociedades humanas e outros fatores bióticos e abióticos (Breilh G Granda, 1985; Barreto, 1990; Sabroza, Toledo G Osanai, 1992). Esse conceito tem representado uma via teórico-metodológica integrativa para se 
entender as correlações entre vida social e desigualdades sociais e sanitárias. Nas sociedades indígenas, a socialização e a organização da vida são moldadas pelas relações de parentesco, que configuram as estratégias tradicionais de ocupação do espaço (territorialização), atualmente modificadas pela força das relações interétnicas, influenciando o modo juvenil de beber, como se demonstrará.

\section{Metodologia}

Realizou-se uma etnografia, entendida como uma "pesquisa de campo com observação prolongada (...), seguida pela produção de dados em condições discursivas e dialógicas, expressos através de formas textualizadas" (Clifford, 2002: 67). O trabalho de campo, que durou seis meses, teve prévia autorização do Comitê Nacional de Ética em Pesquisa.

Em campo, privilegiou-se observar o cotidiano dos jovens que vivem em Iauaretê; quando, como, onde, com quem e o que eles bebem; os discursos sobre o modo como eles bebem e as estratégias empregadas, ou propostas, para regular o consumo.

O modelo analítico desenvolvido por Contandriopoulos (1998), no qual decompõe o contexto social em níveis distintos e inter-relacionados, para apreender as interfaces entre condições de vida e saúde, foi adaptado para atender aos propósitos desta pesquisa (Figura 1, página seguinte). O nível mais abrangente considerado foi a cultura indígena rionegrina, considerando-se que as produções culturais traçam os contornos dos valores e comportamentos em uma sociedade. Buscou-se uma aproximação com os modos e significados, implícitos ou explícitos, do consumo de bebidas alcoólicas, nos mitos e ritos rionegrinos, entendidos como marcadores culturais que orientam normas de comportamento. Igualmente foram valorizados os rituais de iniciação como demarcadores de mudança de status social na população mais jovem.

No nível organização sociopolítica de Iauaretê, explorou-se o impacto do crescimento demográfico e da convivência multiétnica nas formas de interação social, e suas possíveis relações com o incremento de situações em que se consomem bebidas alcoólicas.

As condições de vida foram associadas, no contexto de Iauaretê, ao acesso a diferentes bens e serviços, como escola formal, seguridade social, empregos assalariados e transportes, ou seja, às inovações contemporâneas do viver indígena. No estilo de vida, alocou-se o consumo de bebidas alcoólicas, tanto nos aspectos que se referem ao processo de alcoolização, quanto aos problemas juvenis relacionais ao uso desta substância.

Respostas sociais de enfrentamento foram entendidas como "mediadas pela consciência individual e coletiva acerca das possibilidades de modificação dos 
problemas" (Castellanos, 1997: 71) e foram remetidas à movimentação social estruturada em torno do beber-problema.

Figura 1 - Modelo analítico para compreensão das relações entre o contexto social e os problemas juvenis relacionados ao uso de álcool

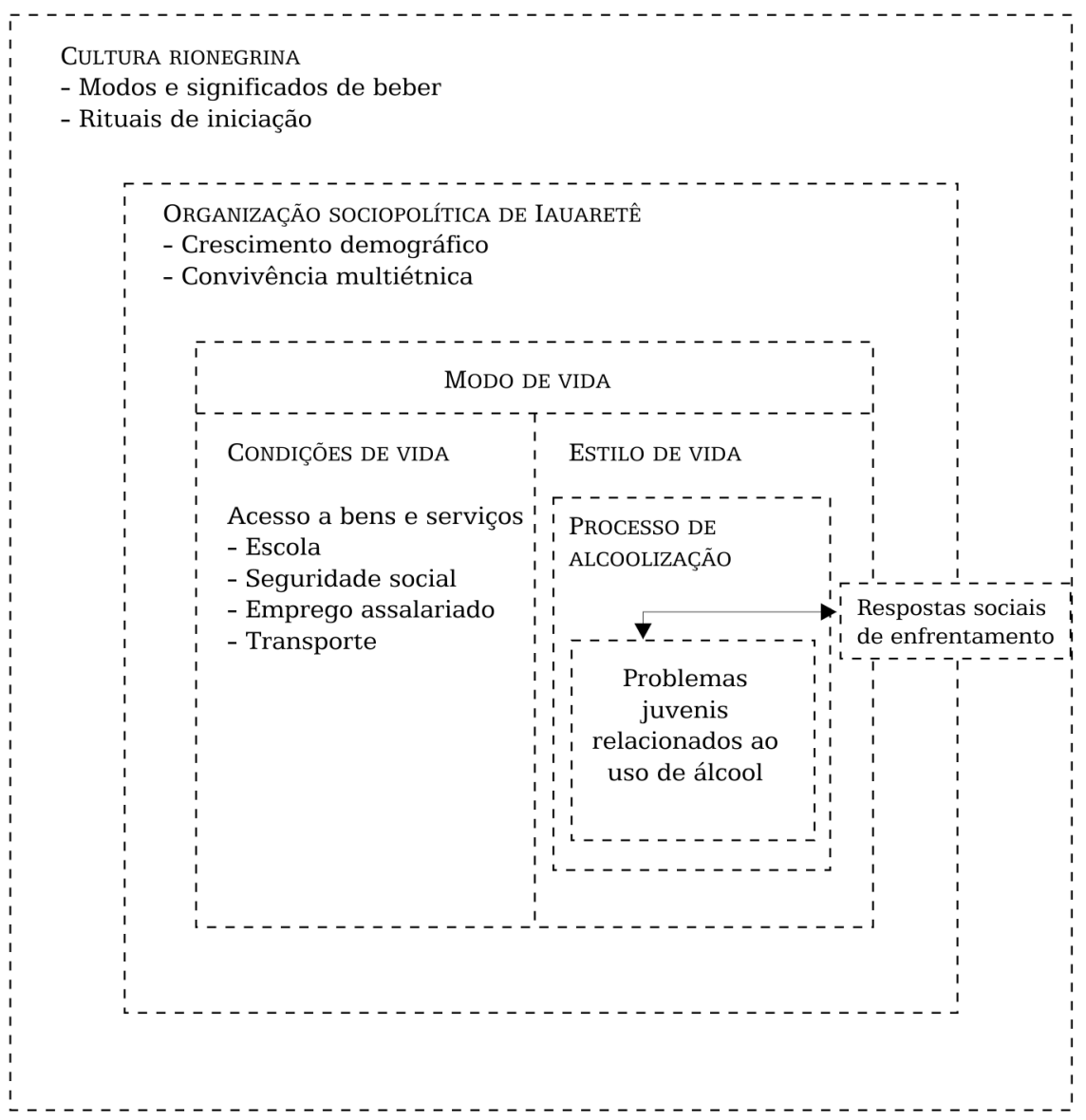

Fonte: Adaptado de Contandriopoulos, 1998.

\section{Resultados e discussão}

\section{Culturas rionegrinas}

Nessas culturas, definem-se como consanguíneos os descendentes de um grupo de irmãos ancestrais, que partilham uma língua comum. Os parentes estão agrupados em unidades sociais menores, sibs, que dispunham, tradicionalmente, de locais específicos de moradia, nos quais erguiam suas casas comunais (malocas). Os consanguíneos devem buscar esposas junto a falantes de outra língua que residiriam em outras localidades (Jackson, 1983; Chernela, 1993). 
Na mitologia, os cunhados potenciais, ou reais, são representados como inimigos, cuja periculosidade pode ser 'domesticada', mas jamais anulada, pelo estabelecimento das trocas matrimoniais (Chernela, 1993).

Conforme a tradição, o consumo ritual de caxiri teria a potencialidade de promover a reconciliação dos inimigos, mesmo temporariamente. Entretanto, nessas mesmas ocasiões, conflitos eclipsados no cotidiano podem emergir na forma de agressão. Assim, o consumo coletivo de bebidas alcoólicas é um importante elemento da vida social, que tanto pode atenuar quanto exacerbar as diferenças (Souza, 2004).

Os dabucuris são festas-rituais, fortemente associadas às trocas matrimoniais, nas quais se consome caxiri e se trocam produtos (Chernela, 1993). A capacidade de oferta de grande quantidade de caxiri pelos membros de uma aldeia evidencia o prestígio da liderança. Habitualmente, se estabelece uma rivalidade amigável. Os visitantes são desafiados pelos anfitriões a consumir toda a bebida, aos quais respondem bravateando que o caxiri ofertado é pouco, em comparação aos regalos que lhes trouxeram (Hill, 1987; Andrello, 2006).

Outrora, a plena participação nessas festas se dava após o ritual de iniciação, que ocorria entre 12 e 13 anos (Hugh-Jones, C., 1979). Durante o processo preparatório, o iniciando era enclausurado e imergia no universo cultural do grupo. Nas festas, o jovem iniciado passava a usar pinturas faciais e os adornos específicos de seu sib, diferenciando-se dos não iniciados (crianças) (Hugh-Jones, C., 1979). A capacidade de ingerir grandes quantidades de caxiri e dançar por horas era indicativa da virilidade juvenil e objeto de orgulho para os parentes (Goldman, 1963).

Somente após o ritual de iniciação, que propiciava a plena identificação como membro do grupo, o jovem estaria apto à busca de parceiras sexuais legítimas, em condição de se tornarem esposas. E apenas após o nascimento dos filhos, o iniciado seria considerado adulto (Jackson, 1983).

\section{Organização sociopolítica de Iauaretê}

Em 2007, a população dessa localidade era estimada em 2.779 habitantes, o quíntuplo da existente em 1975 (Andrello, 2006). Lá estão representados praticamente todos os grupos étnicos da região. Os pequenos e dispersos assentamentos tradicionais, formados por homens de um mesmo sib, foram substituídos por populosos bairros indígenas multiétnicos.

Iauaretê está divida em dez bairros, ou vilas. Cada um possui capela, com seu santo padroeiro, um salão comunitário, onde se realizam festas e outras reuniões; figuras de relevância social como o capitão (chefe político da comunidade), animador, catequista, agente comunitário de saúde e times esportivos de jovens, que competem entre si. 
Nos bairros de Iauaretê, observa-se uma releitura dos ideais de autonomia e independência dos pequenos e dispersos grupos de parentesco, que operam no sentido de evitar a fusão e a perda de limites entre as unidades sociais (Clastres, 2004). Ali, os grupos de vizinhança, formados por parentes e não parentes, buscam manter relações de apoio e solidariedade, em contraposição aos moradores de outros bairros. A proximidade territorial substitui, em certa medida, as formas de socialização típicas da consanguinidade.

Cada vila é um território específico, que interage com outros territóriosvilas que formam o tecido urbano. Em Iauaretê (Andrello, 2006), como em outros contextos urbanos do Alto Rio Negro (Lasmar, 2005), o modo de vida aldeã é a referência com a qual a vida citadina é contrastada. Assim, as vilas são estruturadas, simultaneamente, segundo as relações de parentesco e os novos padrões de assentamento advindos do contato interétnico.

A realização de festas com consumo de bebidas alcoólicas é um meio recorrentemente utilizado na construção e manutenção da identidade grupal. Convidar moradores de outras vilas para suas festas, ou visitá-los em suas comemorações, preserva a distinção entre 'nós' e os 'outros', ainda que para diluílas, parcial e temporariamente, no consumo de bebidas alcoólicas.

A partir de sexta-feira ocorrem, concomitantemente, festas nos salões das diferentes vilas. A ideia de uma festa organizada com todos os moradores não parece fazer sentido. Quando o pároco da missão salesiana resolveu que a festa de São Miguel Arcanjo seria coletiva, os moradores da vila de mesmo nome realizaram no fim de semana anterior à celebração oficial, uma festa própria, demarcando sua especificidade diante das outras vilas.

Além das festas comunais, proliferam outras formas de socialização, mais ligadas ao modo de vida urbano, como as comemorações cívico-religiosas (dia da independência, do índio, carnaval) (Souza G Garnelo, 2007), e as festas 'particulares', como os casamentos e aniversários. Nessas últimas, as interações entre os convivas podem congregar redes de vizinhança, independentemente do pertencimento a bairros determinados. Há, portanto, uma pulverização dos espaços de convivência que proliferam as festas e ampliam a oferta de bebidas alcoólicas.

\section{Condições de vida}

Fomos educados no internato dos missionários

No contexto rionegrino, a introdução da escola formal dificultou a participação dos alunos nos rituais de iniciação e os apartou dos mais velhos. Esses fatos tanto minaram as principais formas de aprendizado dos conhecimentos e valores culturais indígenas, quanto os mecanismos tradicionais de definição do status de adulto naquelas sociedades. 
Com o fim dos rituais de iniciação, com o prolongamento dos anos escolares e a postergação do casamento, vem-se construindo uma nova categoria social, temporalmente dilatada e de limites imprecisos, a de 'juventude'. O consumo de caxiri era algo esperado de um jovem iniciado de 12 ou 13 (Goldman, 1963). Entretanto, anciãos de Iauaretê, que foram alunos do internato, dizem ter começado o uso de bebida com idade mais avançada, pois os padres não lhes permitiam beber.

Com o fim do internato, os jovens passam a beber mais cedo, como 'antigamente', para espanto de seus pais e avós. Isso ocorre num contexto no qual aquele que é chamado de jovem é também associado à categoria de aluno e, conforme uma liderança indígena, 'quem está nesta categoria ainda é criança'.

Eles têm os amigos da escola

$\mathrm{Na}$ escola, convivem jovens de diferentes vilas. Facilmente um jovem terá informações sobre situações de consumo de bebidas alcoólicas que ocorrem nas diferentes vilas de Iauaretê. Se houver uma festa na vila de um 'amigo da escola', um jovem pode ser convidado a beber caxiri. Uma vila distinta da sua é um lugar de 'outras' pessoas. A relação com os amigos da escola lhe permite uma aproximação menos tensa, porém, o salão comunitário, com suas formalidades, sobretudo no começo da festa, é um espaço pouco convidativo. De forma mais comum, antes de se dirigirem ao local da festa, os jovens ficam bebendo caxiri, na casa de um amigo, residente local.

Aos sábados, as festas iniciam por volta de 13 horas, com o capitão da vila explicando os motivos da festa e pedindo que todos bebam juntos e tranquilos. Nessa hora, praticamente não há jovens no salão. Eles estão em suas casas, recebendo visitas; ou nas de outros, sendo visitantes.

Pais, mães e lideranças não aprovam essa prática. Entretanto, dizem que não podem expulsar os jovens visitantes e que não lhes oferecer caxiri daria a entender que têm inimizade com eles ou com seus pais. Além disso, caso o filho disponha de pouco caxiri para oferecer aos amigos, isso seria algo vexatório, subentendendo sovinice (recusa a partilha) ou preguiça (sobretudo da mãe do jovem, que não teria preparado uma boa quantidade da bebida).

A depender do ponto de vista, o jovem anfitrião é representado como alguém que 'desencaminha' o outro jovem ao chamá-lo para sua casa, obrigandoo a beber grandes quantidades de caxiri. Alternativamente, o visitante pode ser descrito como alguém que se aproveita das regras de etiqueta local para beber o 'pouquinho' de caxiri que a mãe de seu amigo preparou para levar para o centro comunitário.

A ida à casa do amigo permite tanto uma entrada menos abrupta num espaço da alteridade (o salão comunitário), como multiplica as oportunidades de 
beber, criando-se um espaço juvenil para esta prática, diferenciado do ambiente de consumo coletivo. Possuidores de uma rede heterogênea de contatos nos diversos bairros, os jovens passam, sem maiores dificuldades, a transitar de vila em vila, consumindo caxiri.

Aqui é proibido, mas muitos índios estão trazendo

Apesar da venda de cachaça ser proibida em terra indígena (Brasil, 1973), é fácil encontrar o produto em Iauaretê. A relativa facilidade de deslocamento entre Iauaretê e a sede municipal, propiciada pela grande circulação de barcos, facilita a entrada de cachaça, seja para consumo pessoal ou para venda.

Diferentemente do observado em outras localidades da região (Souza G Garnelo, 2007), o acesso dos jovens a essa bebida parece maior, ainda que os preços sejam elevados. Isso ocorre num contexto no qual é maior a circulação de dinheiro. Para comprar cachaça, os jovens podem valer-se das amizades com militares indígenas; vender produtos extrativistas; ludibriar aposentados ou coagir parentes idosos que "não veem seu dinheiro, porque os netos pegam tudo", conforme um septuagenário. Em algumas situações, observou-se que os pais ou avós simplesmente davam dinheiro para os jovens, a fim de 'fazê-los felizes'. Uma vez obtido o dinheiro, os jovens costumam se cotizar e comprar cachaça.

Assim, a crescente monetarização das relações, associada ao incremento da circulação de pessoas e produtos entre Iauaretê e São Gabriel da Cachoeira, é um fator que vem confluindo para facilitar o acesso dos jovens às bebidas alcoólicas industrializadas.

\section{Respostas sociais de enfrentamento}

Dados etnográficos mostram que no Alto Rio Negro, como em outras sociedades indígenas, o controle sobre o beber é intrinsecamente relacionado à disponibilidade da bebida (Kunitz G Levy, 1994; Souza G Garnelo, 2007). Analogamente, em Iauaretê, as estratégias aventadas para lidar com o beberproblema juvenil buscavam restringir o acesso a bebidas.

Porém, durante a pesquisa de campo, observou-se que essas propostas não eram efetivadas na prática. Os dados revelam que as festas cumprem uma função muito mais ampla que o congraçamento entre os presentes. Assim, reduzilas demandaria a alteração de estruturas culturais que demarcam a identidade dos grupos e as relações de prestígio das lideranças. A redução, ou supressão, desses eventos obrigaria as lideranças a buscar novos caminhos para apaziguar diferenças e circunscrever hostilidades. Trata-se de uma difícil tarefa, sobretudo se consideramos a fragilidade dos laços que unem os moradores das vilas, que se valem principalmente da condição de corresidentes para manter a coesão social necessária à vida comunal. 
Outro aspecto relevante está ligado à participação feminina nesse contexto. Tradicionalmente, a mulher é responsável pela produção de alimentos e bebidas, o caxiri inclusive. Provê-los em grande quantidade é algo esperado e demandado do polo feminino dos núcleos familiares (Lasmar, 2005). Suprimir a produção de caxiri implicaria solapar o ideal do zelo feminino com a roça e com a manufatura de produtos derivados da mandioca.

Ademais, nas últimas décadas, as mulheres de Iauaretê passaram a auferir lucro com a venda do caxiri. Iniciativas para reduzir sua venda geraram descontentamento entre as mulheres, porque essa fonte de renda representa um aporte financeiro importante para a manutenção das unidades domésticas, num contexto de progressiva ampliação da dependência de bens industrializados de consumo.

No plano político, algumas lideranças associam a proibição legal de entrada da cachaça em área indígena a uma manifestação do sistema jurídico tutelar, que considera o índio legalmente incapaz. Alguns indígenas que se manifestam a favor da proibição comercializam cachaça em Iauaretê. Outros são a favor da proibição da entrada desta bebida, mas caso tenham acesso a ela, costumam consumi-la. Em síntese, trata-se de uma questão em torno da qual é difícil se construir um único consenso.

Por fim, um grupo minoritário de lideranças aponta a necessidade de se repensar não apenas o modo de beber dos jovens, mas o próprio modo de se viver em Iauaretê. Posta em prática por alguns anciãos, observou-se uma abordagem baseada na ideia de que o controle dos excessos alcoólicos dos jovens passa pela revalorização do respeito à hierarquia ritual característica do modo tradicional de vida (Jackson, 1983; Chernela, 1993), pelo aprendizado dos mitos, das músicas, danças e outras práticas ancestrais que vêm caindo progressivamente em desuso na região. Fiéis à sua proposta, esses anciãos vêm investindo no ensino de danças e mitos para os jovens, utilizando, para tal, o espaço interior de malocas reconstruídas por lideranças das associações indígenas. Seu trabalho é apoiado por uns, criticados por outros. Para alguns, o mundo mudou e este tipo de conhecimento não teria mais serventia. Para esses anciãos, o mundo mudou e é por isso que concebem a possibilidade de transformar a situação atual de Iauaretê, e veem no retorno às tradições uma alternativa para promoção de mudanças sociais.

\section{Juventude em um mundo em transformação}

Em Iauaretê, cada vila-bairro é vista como uma localidade autônoma, operando em moldes semelhantes ao de uma aldeia indígena, alternando alianças e disputas com consanguíneos e afins, num processo intensificado pela proximidade e pela alta densidade demográfica. Assim, multiplicam-se as situações em que se 
bebe, que remetem à criação e à manutenção de sentimentos de pertencimento e de demarcação de diferenças, fazendo parte dos mecanismos sociais de gerenciamento de conflitos.

A inserção da juventude no tecido social é precária, situando-se a meio caminho entre a posição chancelada pela tradição (recém-iniciado, na ausência de iniciação) e aquela gerada pela colonização (estudante-infantilizado). Ademais, com os novos padrões de territorialização, reordenam-se as formas de interação entre os subgrupos de jovens e suas famílias. Sai do primeiro plano o pertencimento à descendência de ancestrais comuns e se tornam preponderantes os grupos de vizinhança (vilas, formadas por parentes e não parentes que se tornam corresidentes), de amigos da escola (moradores dos diferentes bairros) e outros.

Nesse contexto, os jovens estão inseridos em múltiplas redes de interação social, que igualmente têm no consumo grupal de bebidas alcoólicas um mecanismo de expressão de alianças. Por meio delas, os jovens podem se cotizar para comprar bebida (caxiri ou cachaça), beber longe do olhar dos pais quando vão para casas de amigos em outras vilas e criar um ambiente juvenil de consumo.

Ao incidirem nesses jovens de status ambíguo e de redes de interação amplas, as regras de etiqueta social tornam-se inevitavelmente contraditórias. Por um lado, sendo estudantes, são equiparados a crianças, que não deveriam beber, pensamento que é influenciado pela experiência dos mais velhos como alunos do internato missionário. Por outro lado, demanda-se dos jovens que ingiram grandes quantidades de caxiri, demonstrando tanto virilidade, como confiança e respeito pelos anfitriões. Valendo-se dessas mesmas regras, os jovens reivindicam que lhes seja servido caxiri, seja nos contextos de consumo coletivo, nos salões comunitários, ou microgrupais, na casa de amigos. Ademais, o dinheiro obtido pelos jovens permite-lhes comprar bebida, inserindo-os nas relações de comércio que geram renda para outras famílias, num contexto de crescente monetarização.

Assim, observa-se que em Iauaretê vêm ocorrendo importantes transformações na organização social e nas condições de vida, que se refletem nos modos de beber, particularmente daqueles que são chamados de jovens. Porém, diferentemente do senso comum local, o modo de beber juvenil não se configura como resultante de um sistema cultural combalido e perdido. Alternativamente, é o próprio sistema que configura e cria condições de possibilidade para esta prática juvenil, mesmo que para isso pague-se um preço, na medida em que os mecanismos tradicionais/comunais de coibição de excessos são incapazes de operar plenamente no estilo urbanizado de vida praticado em Iauaretê.

A etnografia realizada possibilitou evidenciar as relações que se estabelecem entre o modo de vida indígena contemporâneo e a representação e configuração de agravos à saúde, localmente identificados como prioritários, como no caso do beberproblema juvenil. Entende-se que, com este estudo, puderam-se aventar alternativas 
teórico-metodológicas para investigar as relações entre os modos de vida e a produção da saúde e da doença, incorporando à análise a cultura (e sua transformação), a vida cotidiana (e suas contradições), as pessoas (e suas subjetividades).

Notas

1 Este capítulo é uma versão de: Souza, M. L. P.; Deslandes, S. F. G Garnelo, L. Modos de vida e modos de beber de jovens indígenas em um contexto de transformações. Ciência G Saúde Coletiva, 15(3): 709-716, 2010. Texto republicado com autorização dos autores e do editor da revista.

2 Ver também o capítulo 4 deste livro.

\section{Referências}

ALMEIDA-FILHO, N. Modelos de determinação social das doenças crônicas não transmissíveis. Ciência G Saúde Coletiva, 9(4): 865-884, 2004.

ANDRELlO, G. Cidade do Índio: transformações e cotidiano em Iauaretê. São Paulo: Unesp, ISA, 2006.

BARRETO, M. L. A epidemiologia, sua história e crises: notas para pensar o futuro. In: COSTA, D. C. (Org.). Epidemiologia: teoria e objeto. Rio de Janeiro, São Paulo: Abrasco, Hucitec, 1990.

BRASIL. Lei n. 6.001 de 19 dez. 1973. Dispõe sobre o Estatuto do Índio. Diário Oficial da União, Brasília, 1973.

BREILH, J. G GRANDA, E. Os novos rumos da epidemiologia. In: NUNES, E. D. (Org.). As Ciências Sociais em Saúde na América Latina: tendências e perspectivas. Brasília: Organização Pan-Americana da Saúde, 1985.

CASTELLANOS, P. L. Epidemiologia, saúde pública, situação de saúde e condições de vida: considerações conceituais. In: BARATA, R. B. (Org.). Condições de Vida e Situação de Saúde. Rio de Janeiro: Abrasco, 1997.

CHERNELA, J. M. The Wanano Indians of the Brazilian Amazon: a sense of space. Austin: University of Texas Press, 1993.

CLASTRES, P. Arqueologia da Violência: a guerra nas sociedades primitivas. São Paulo: Cosac Naify, 2004.

CLIFFORD, J. A Experiência Etnográfica: antropologia e literatura no século XX. Rio de Janeiro: Editora UFRJ, 2002.

CONTANDRIOPOULOS, A. P. Pode-se construir modelos baseados na relação entre contextos sociais e saúde?. Cadernos de Saúde Pública, 143(1): 199-204, 1998.

EDWARDS, G.; MARSHALL, E. J. G COOK, C. C. H. O Tratamento do Alcoolismo: um guia prático para profissionais de saúde. 3. ed. Porto Alegre: Artes Médicas, 1999.

GOLDMAN, I. The Cubeo: indians of the Northwest Amazon. Urbana: University of Illinois Press, 1963. 
GROPPO, L. A. Juventude: ensaios sobre sociologia e história das juventudes modernas. Rio de Janeiro: Difeli, 2000.

HILL, J. Wakuenai cerimonial exchange in Northwest Amazon. Journal Latin American Lore, 13(2): 183-224, 1987.

HUGH-JONES, C. From the Milk River: spatial and temporal processes in Northwest Amazonia. Cambridge: Cambridge University Press, 1979.

HUGH-JONES, S. The Palm and the Pleiades: initiation and cosmology in Northwest Amazonia. Cambridge: Cambridge University Press, 1979.

JACKSON, J. E. The Fish People: linguistic exomamy and Tukanoan identity in Northwest Amazon. Cambridge: Cambridge University Press, 1983.

KUNITZ, S. J. P. G LEVY, J. E. Drinking Careers: a twenty-five-year study of three Navajo populations. New Haven, London: Yale University Press, 1994.

LASMAR, C. De Volta ao Lago de Leite: gênero e transformação no Alto Rio Negro. São Paulo, Rio de Janeiro: Unesp/ISA, Nuti, 2005.

PAGLIARO, H.; AZEVEDO, M. M. G SANTOS, R. V. Demografia dos Povos Indígenas no Brasil. Rio de Janeiro: Editora Fiocruz, 2005.

SABROZA, P. C.; TOLEDO, L. G OSANAI, C. H. Organização do espaço e os processos endêmico-epidêmicos. In: LEAL, M. C. et al. (Orgs.). Saúde, Ambiente e Desenvolvimento. 1. ed. Rio de Janeiro, São Paulo: Abrasco, Hucitec, 1992.

SoUZA, M. L. P. Alcoolização e Violência no Alto Rio Negro, 2004. Dissertação de Mestrado, Manaus: Universidade Federal do Amazonas.

SOUZA, M. L. P. G GARNELO, L. Quando, como e o que se bebe: o processo de alcoolização entre populações indígenas do Alto Rio Negro, Brasil. Cadernos de Saúde Pública, 23(7): 1.640-1.648, 2007. 


\section{Consumo de Bebidas Alcoólicas entre os Povos Indígenas do Uaçá}

Bebidas alcoólicas têm sido consumidas por praticamente todas as sociedades humanas desde os tempos mais remotos. Há evidências documentadas de que, entre os sumérios, por volta de 3.200 a. C. (Mandelbaum, 1965), a principal bebida usada era a cerveja, considerada um alimento importante, e seu consumo estava integrado à mitologia, religião e economia (Katz G Voigt, 1986). Quando práticas culturais como essa adquirem difusão tão geral, ainda que, em determinadas circunstâncias, possam trazer consequências negativas, é sensato considerar o seu potencial positivo como mecanismo cultural adaptativo (Harris, 1980).

A positividade da embriaguez sistemática refere-se ao afrouxamento das restrições da existência mundana pela experiência de estados alterados de consciência (Rudgley, 1993). Livrar-se, por algum momento, de tais restrições traz um alívio da pressão do coletivo sobre o indivíduo. Além disso, o alívio do controle social sobre os comportamentos, por paradoxal que possa parecer, também é uma forma de reafirmar a necessidade deste controle, porque a embriaguez induzida pelo álcool permite explorar situações potencialmente perigosas, e esse temor é um estímulo para reafirmar a solidariedade que funda os laços sociais da vida cotidiana.

Festas, comemorações e celebrações são os momentos sociais consagrados pela maioria das sociedades humanas para a experiência de estados alterados de consciência induzidos pelo consumo de substâncias psicoativas. Por essa razão, conforme sustenta McDonald (1994), há uma profunda relação entre festividades e o consumo de bebidas alcoólicas.

O álcool não é a única substância psicoativa que cumpre o papel de aliviar o controle social, mas sem dúvida é a mais difundida. O estado de êxtase também pode ser induzido por orações, meditações, música e dança, e não apenas pelo uso de substâncias intoxicantes (Rudgley, 1993). A preferência pelo álcool nas festas pode ser compreendida pela afinidade eletiva entre os efeitos químicos daquele e a 'química cultural' destas (MacAndrew G Edgerton 1969; Gusfield, 1987). As festas afrouxam os controles sociais porque permitem, e até encorajam, 
comportamentos que, em dias comuns, não seriam bem aceitos ou receberiam reprovação explícita. E o álcool, sendo uma substância depressora do sistema nervoso central, atenua a ação dos mecanismos de contenção do comportamento que atuam mais eficazmente quanto se está sóbrio (Milan G Ketcham, 1986). A conjunção dos dois fatores produz o que MacAndrew e Edgerton (1969) e Gusfield (1987) denominam de remissão cultural e inversão simbólica, possibilitando que os efeitos químicos do álcool reflitam a química cultural das festas. Remissão cultural referese à maior permissividade social, apontada anteriormente. Inversão simbólica diz respeito ao cancelamento da identidade normal e a adoção temporária da identidade de outra pessoa. Bons exemplos são os casos dos homens que se vestem de mulher ou vice-versa, durante o Carnaval e as festas juninas, e casos em que aquele que normalmente ocupa o topo da hierarquia social passa para uma posição de subserviência, geralmente sendo alvo de brincadeiras e piadas.

A remissão cultural e a inversão simbólica proporcionada pelas festas e pelo consumo de bebidas alcoólicas instauram períodos limiares, constroem outra realidade. Uma realidade desejada que projeta um 'mundo ideal' (Douglas, 1987), porém ameaçador. $\mathrm{O}$ que se quer é visitar esse mundo ideal, e não passar a viver nele. O que se procura é a experiência do êxtase e, ao mesmo tempo, atenuar as pressões sociais sobre o comportamento. O contraponto é obtido por meio de regras sociais que orientam a realização das festas e o consumo de bebidas alcoólicas, uma vez que, se o álcool é um elemento essencial para operar as inversões simbólicas e a remissão cultural nos rituais festivos, a domesticação dos estados de efervescência é imprescindível.

Por essa razão, Heath (1998) analisa a circunscrição do consumo de bebidas alcoólicas num sistema de práticas culturais como uma estratégia para reduzir os riscos potenciais de desagregação social e, ao mesmo tempo, garantir a positividade da experiência de estados alterados de consciência. Assim, entre as mais diferentes sociedades humanas, o uso do álcool é orientado por regras e tradições culturais que prescrevem seu consumo com funções sociais e cerimoniais, da mesma forma que proscrevem a embriaguez excessiva e sem ponderação, fazendo com que os benefícios sociais e individuais de seu consumo não sejam sobrepujados pelos prejuízos potenciais. Heath (1998) acrescenta, ainda, que é por essa razão que os padrões contemporâneos do uso do álcool, em sociedades definidas como modernas ou tradicionais, apresentam similaridades individuais, coletivas e culturais, porque, em ambos os casos, encontra-se tanto a necessidade de experimentar estados alterados de consciência que transcendam a vida diária quanto o risco do consumo descontrolado e, portanto, da embriaguez contínua e deliberada. 


\section{Álcool e cultura: pressupostos teóricos}

O pressuposto teórico que orienta este capítulo apoia-se no fato de que o efeito comportamental do consumo de qualquer substância psicoativa, neste caso específico o álcool, não pode ser compreendido, simplesmente, pela ação farmacológica da substância no organismo. Depois de beber, as pessoas agem de acordo com o que a cultura e a sociedade esperam daqueles que bebem.

Marshall (1979) denomina os estudos comparativos sobre o consumo de bebida como um experimento natural clássico, porque estão em jogo uma única espécie (Homo sapiens), uma única substância (etanol) e uma ampla variedade de comportamentos resultantes de seu consumo.

Os efeitos fisiológicos e psicológicos são bastante conhecidos. A ingestão de moderada à alta produz a redução da velocidade de reação a estímulos externos; afeta a memória, especialmente a curta e a intermediária, bem como a capacidade de resolver problemas e controlar as funções motoras.

A noção de experimento natural, proposta por Marshall (1979), permite romper com qualquer abordagem que estabelece efeitos causais diretos do álcool no comportamento e observar a estreita interação entre álcool e cultura. Como exemplo, nota-se em várias sociedades a relação estreita entre a bebida e atitudes agressivas e beligerantes, ao passo que, em outras, observam-se comportamentos bastante opostos: bom humor, passividade e calmaria (Heath, 1998).

Essa variabilidade de respostas de comportamentos se explica pelo fato de que tanto a atitude de beber quanto a maneira de ser afetado pelo álcool estão inseridas no processo de socialização (Critchlow, 1986). Se as representações individuais e coletivas acerca do álcool forem de agressividade, então há grande possibilidade de as atitudes se tornarem violentas. Entretanto, se as expectativas forem de que a bebida trará mais desinibição, os resultados serão de mais espontaneidade.

As expectativas sociais e individuais em relação à bebida modelam as atitudes de quem bebe, além de darem forma às justificativas e desculpas possíveis que decorrem dessas atitudes. Em contextos socioculturais nos quais o álcool encontra-se vinculado à violência, há uma forte tendência de se justificar condutas beligerantes apelando-se para o fato de a pessoa agir sob efeito do álcool; é como se estivesse fora de seu estado normal de consciência. Por sua vez, em contextos em que o álcool está revestido com positividade, apelar para a bebida como desculpa para atitudes agressivas e violentas, não só será inócuo, como intensificará a gravidade da ofensa.

Após essas considerações, já é possível expor o foco deste capítulo, a saber, os significados sociais e simbólicos do consumo de bebidas alcoólicas entre os povos indígenas Karipuna, Galibi-Marworno, Palikur e Galibi Kali'na, todos 
localizados nas Terras Indígenas Uaçá, Juminã e Galibi de Oiapoque, município de Oiapoque, no extremo norte do estado do Amapá. Já está bastante estabelecido na literatura antropológica sobre o tema que, onde quer que um ou mais tipos de bebida alcoólica estejam disponíveis, seu consumo é utilizado para definir o mundo social em termos de significados simbólicos. São poucas ou inexistem as bebidas 'neutras', sem significado. Toda bebida é um veículo simbólico, carrega uma mensagem. Identifica, discrimina, constrói e manipula sistemas sociais, valores, relações interpessoais, normas e expectativas de comportamento.

Parte-se do princípio de que o consumo do álcool é feito sob orientação de padrões socioculturais que o estruturam e representam sua fonte de sentido. O que e por que se consome, seu efeito no comportamento e a avaliação deste podem ser explicados apenas com referência a tais padrões. Assim, uma investigação acerca dos aspectos sociais e simbólicos do consumo de bebidas alcoólicas entre os povos indígenas do Uaçá possibilitará compreender quais são os estilos indígenas de consumo e, a partir daí, entender as suas percepções do bem beber e dos excessos indesejáveis.

A hipótese é de que o consumo de bebidas alcoólicas entre os povos indígenas do Uaçá é ambivalente, ou seja, a qualificação de seu consumo é positivada quando for expressão de sociabilidade adequada entre as famílias, entre os grupos e entres estes com o sobrenatural, e é tornada negativa quando representar ruptura dessa sociabilidade. O bem beber e o consumo indesejável não estão diretamente ligados à quantidade de bebida ingerida, portanto a noção de excesso ganha sentido apenas se relacionada ao contexto específico no qual ocorre.

\section{Povos indígenas do Uaçá}

As populações que atualmente se autodefinem como Karipuna, GalibiMarworno, Palikur e Galibi Kali'na vivem distribuídas, respectivamente, nas Terras Indígenas mencionadas anteriormente. As três Terras reunidas, todas demarcadas e homologadas por decreto presidencial n. 298 desde 29 de outubro de 1991, formam uma extensa área, com um número de habitantes pouco superior a 7.000. A população está distribuída principalmente ao longo de três rios: Karipuna no rio Curipi, Galibi-Marworno no Uaçá e Palikur no Urukauá. No rio Oiapoque está localizada a Terra Juminã, onde residem Karipuna e Galibi-Marworno, e a Terra Galibi de Oiapoque, onde residem Galibi Kali'na e Karipuna. Na estrada BR-156, que liga as cidades de Macapá e Oiapoque, há aldeias Karipuna, Galibi-Marworno e, mais recentemente, Palikur.

Os Karipuna costumam ir com mais frequência ao centro urbano mais próximo, a cidade do Oiapoque. De qualquer forma, todos esses grupos costumam deslocar-se das aldeias ao Oiapoque com intervalos que variam de uma semana a 
quinze dias para comercializar a farinha, o peixe, e frutas como banana e laranja, além de comprar arroz, café, açúcar, bolacha, sabão, combustível (gasolina, querosene, óleo diesel) etc. Geralmente chegam cedo, antes das 8 horas, e só retornam à tarde, depois das 16 horas. Nesse período, além de comprar e vender víveres, ir ao banco, à Funai etc., aproveitam para frequentar postos de venda de bebidas alcoólicas, tanto para consumo no próprio local quanto para levar para as aldeias.

A maior parte da população indígena Karipuna encontra-se às margens do rio Curipi, principalmente no seu baixo e médio curso. Além das quatro aldeias maiores e principais - Manga, Espírito Santo, Santa Isabel e Açaizal - existem várias outras localidades residenciais dispersas ao longo do Curipi e da estrada BR-156, mais precisamente na altura dos Km 40, 50 e 70. Apesar da dispersão, cada uma dessas localidades reconhece sua ligação com uma das quatro aldeias maiores. De um ponto de vista étnico, a população Karipuna é bastante diversificada, com famílias de origem brasileira que se casaram com os índios do rio Curipi. Falam o patoá, língua geral utilizada no contato com as outras etnias da região e o português, e certo número deles, em especial homens, fala o francês, devido à proximidade com a Guiana Francesa, onde muitos residem ou residiram, trabalhando em Saint Georges e Caiena.

Os Galibi-Marworno são um grupo numeroso, de origem heterogênea, e falantes do patoá. Apesar da proximidade do nome, não têm parentesco com os Galibi Kali'na, constituindo-se de grupos Carib remanescentes da Guiana Francesa e de etnias Marworno do Amapá. A língua falada pelos Galibi-Marworno históricos entrou em desuso há pelo menos cem anos. Mas há lembranças de velhos que ainda a falavam. Nimuendajú, em 1926, fez uma lista de palavras e, em 1996, Vidal conseguiu, ainda que com dificuldades, uma lista bem menor. Entretanto, um número expressivo de palavras é indígena, especialmente aquelas referentes à fauna e avifauna. Em alguns cantos xamânicos há trechos em 'língua antiga', por isso alguns índios velhos dizem que apenas conseguem falar algo em Galibi quando estão de 'porre', ${ }^{2}$ após tomar caxiri. ${ }^{3}$

Os Palikur foram mencionados pela primeira vez em 1513, nos relatos do navegador espanhol Vicente Yáñez Pinzón, que batizou a costa ao norte da foz do rio Amazonas de província Paricura, ${ }^{4}$ em alusão aos Palikur. As corruptelas do etnônimo Palikur podem ser encontradas em relatos de viajantes, documentos oficiais, artigos e monografias etnográficas, sempre com poucas alterações gráficas e de pronúncia, tanto em português quanto em francês, produzindo nomes como Paricur, Pariucur, Paricurene, Paricour, Pariucour, Palicours. Atualmente são conhecidos na região do Oiapoque como Palikur. Os Palikur são evangélicos (Assembleia de Deus) desde a década de 1960, falam uma língua própria, do tronco aruaque, do qual se orgulham por ser um distintivo e certificado de identidade indígena. Falam o português, patoá e muitos também dominam o francês. Em 
relação aos Palikur que moram na Guiana Francesa, apesar da mesma língua, há diferenças significativas. Os Palikur do Brasil vivem em aldeias mais isoladas, ao passo que os do lado francês vivem em bairros dentro das cidades de Saint Georges e Caiena, a capital da Guiana Francesa (Capiberibe, 2001).

Os Galibi Kali'na vivem às margens do rio Oiapoque, e a denominação Galibi também se refere aos índios que vivem na Guiana Francesa, especialmente nos rios Maroni e Mana. Na Guiana Francesa eles se definem como Kali'na; Galibi foi uma designação genérica empregada pelos exploradores europeus para referiremse aos povos de língua caribe do litoral das Guianas. Os Galibi mantêm parcialmente a sua língua original porque esta não é mais falada pelas crianças e jovens, que estudam apenas o português, embora compreendam a língua galibi. Na medida em que o contato com os parentes da Guiana é muito raro, a tendência é perder a língua. De qualquer forma, os Galibi Kali'na também falam o português e patoá, utilizados tanto na aldeia como nos contatos externos. Os mais velhos conhecem o francês porque foram alfabetizados e educados nesse idioma.

De um ponto de vista sociocultural, os quatro grupos têm características comuns, fruto de redes de relações interétnicas, extensas no tempo e no espaço, que também envolvem as populações das cidades e localidades vizinhas do lado brasileiro, as pequenas vilas de Palikur e de Saramaká (ex-escravos de origem africana refugiados de antigas colônias holandesas) às margens do rio Oiapoque, na Guiana Francesa. Contudo, ao mesmo tempo em que partilham uma tradição, esses grupos também possuem características próprias que os distinguem uns dos outros, com diferenças de organização social, de crenças religiosas e particularidades linguísticas.

A região do Baixo Oiapoque tem uma longa história de contatos, migrações e fusões que recua até o final do século XVI e começo do XVII, quando espanhóis, portugueses, franceses, ingleses e holandeses visitaram a região. Sintetizar três séculos de história em poucos parágrafos é tarefa impossível. Faço apenas o registro desta história para chamar a atenção da complexidade dos processos que presidiram a construção dos atuais povos indígenas do Uaçá.

\section{Contextos de consumo}

Entre os povos indígenas da região sudeste das Guianas, o consumo de caxiri historicamente sempre esteve ligado às atividades produtivas: trabalhos em família, trabalhos comunitários, mutirões e 'convidados de plantar' (grandes mutirões realizados para o plantio da mandioca entre os meses de novembro e fevereiro). Essas atividades são realizadas no âmbito de círculos de cooperação e ajuda mútua que acionam diversos grupos nucleares constituindo-se, assim, as unidades essenciais para a formação dos grupos locais, base para a reprodução 
material e simbólica de todas as quatro populações: Karipuna, Galibi-Marworno, Palikur e Galibi Kali'na.

O caxiri também está ligado às festas, reuniões informais e aos rituais. Karipuna e Galibi-Marworno vinculam o consumo de caxiri ao Turé ${ }^{5}$ e às demais festas de natureza religiosa e profana. Este também era o caso dos Palikur antes de aderirem ao pentecostalismo, a partir da década de 1960 em diante. Entre os Galibi Kali'na, como ocorre com os demais grupos, o caxiri é uma bebida eminentemente coletiva, porém, hoje, ligada a festas e a rituais profanos ou católicos.

Nas atividades produtivas, são acionados diversos grupos de cooperação que trabalham na construção e manutenção de casas, produção de farinha, tanto para consumo doméstico como para venda, na provisão de comida e bebidas (caxiri ou outras bebidas compradas nas cidades) a serem consumidas, por exemplo, durante um 'convidado de plantar'. Esses grupos também atuam na construção das capelas, da escola, enfermaria, casa da festa, das casas de farinha comunitárias - nas aldeias onde existem -, na limpeza dos espaços e caminhos de domínio público, fiscalização e manutenção dos limites da demarcação.

Das atividades produtivas realizadas coletivamente, os 'convidados de plantar' são os maiores, conforme esclarecido anteriormente. Os grupos nucleares que os promovem geralmente o fazem por meio de um convite com uma semana de antecedência, e, de boca em boca, a informação vai se espalhando pela aldeia. Convidam-se mais pessoas do que o necessário, porque algumas acabam não podendo participar. Mas uma vez que se aceita o convite, estabelece-se uma relação de reciprocidade obrigatória. Quem convida oferece em quantidades generosas comida, bebida e tabaco, e, em troca, recebe a ajuda. Ambos, caxiri e cachaça são oferecidos, mas atualmente a cachaça é mais comum.

Com relação ao consumo de bebidas em rituais xamânicos, festas e reuniões, os Karipuna são, atualmente, os que realizam com mais frequência o Turé, consumindo grandes quantidades de caxiri. A bebida também está presente nas festas de santo, assembleias políticas, festividades do Dia do Índio e competições esportivas (denominadas 'olimpíadas'). As festas de santo, realizadas nas Terras Indígenas do Uaçá, caracterizam-se como homenagens aos santos padroeiros e representam um forte indício da presença do catolicismo de tradição europeia entre todos os grupos: Karipuna, Galibi-Marworno, Galibi Kali'na, e entre os Palikur até a década de 1960. Essas festas representam um dos momentos sociais de maior consumo de bebidas alcoólicas, de todos os tipos, mas especialmente de cachaça.

Os Galibi-Marworno realizam pouco o Turé, mas recentemente vêm retomando as práticas xamânicas e o Turé, para acompanhar festividades como o Dia do Índio ou o Dia das Crianças. Mesmo assim, eles nunca deixaram de fabricar o caxiri para as ocasiões de festas, como as mencionadas anteriormente para o caso dos Karipuna, ou mesmo em um fim de semana qualquer. 
Entre os Palikur, o Turé e as demais festas tradicionais ligadas ao universo xamânico são realizadas no contexto das 'festas do mundo': são comemorações realizadas pelos chamados 'desviados', isto é, por quem está afastado, ainda que temporariamente, da Igreja. Além do consumo de caxiri e de outras bebidas alcoólicas, tocam-se músicas de estilo regional e popular, todas desaconselhadas pela igreja Assembleia de Deus: o brega, a lambada, o forró e ritmos mais comuns nas cidades como o dance. Festas ligadas ao xamanismo também podem ser realizadas durante o Dia das Crianças, ou em comemorações cívicas como o 7 de setembro, Dia do Índio, e em outras ocasiões especiais, como a formatura escolar dos alunos e assembleias políticas. Nesses momentos, tais festas têm caráter de apresentação. Como dizem: "é apenas uma maneira de mostrar a cultura do índio". A ênfase recai sobre o conteúdo étnico em detrimento dos aspectos cosmológicos.

Entre os Galibi Kali'na, os xamãs deixaram de existir a partir dos anos 1960, ainda que as crenças em práticas antigas não tenham acabado. Se as crenças xamânicas persistem, as práticas ligadas a esse universo, por sua vez, mantêm-se adormecidas. Assim, o consumo de bebidas alcoólicas - de caxiri e outras - não está simbolicamente vinculado ao Turé, até porque eles nunca praticaram esse ritual, mas está vinculado ao Natal, ao Ano Novo, à Páscoa, ao Dia do Índio, às festas juninas e às festas de santo. Em tais ocasiões, consomem o caxiri - preparado de forma diferenciada dos outros grupos da região, cuja receita é bastante refinada e obedece a regras sociais estritas -, além de outras bebidas compradas na cidade: cerveja, vinho, champanha e cachaça. Os sentidos que orientam o consumo dessas bebidas parecem estar alinhados com as atitudes da população regional em ocasiões festivas, privilegiando-se, além do caxiri, símbolo de identidade indígena, o vinho, aperitivos e a champanha, como é costume na Guiana Francesa. ${ }^{6}$

\section{Caxiri e cachaça: distinções e aproximações simbólicas}

Nos contextos apontados, conforme mencionado, todas as quatro populações fazem uso do caxiri e de outros tipos de bebidas alcoólicas, principalmente da cachaça, cuja presença entre as populações indígenas do Uaçá é antiga, remontando à chegada dos primeiros viajantes, aventureiros e comerciantes no século XVII, já que, a partir desse período, os índios nunca viveram isolados dos diferentes segmentos populacionais que também passaram a habitar a região. $\mathrm{Na}$ medida em que a cachaça começou a estar presente nos momentos rituais xamânicos, festivos, nas atividades produtivas e no lazer, os significados simbólicos associados ao seu consumo assemelham-se aos do caxiri: elemento de troca e sociabilidade entre os grupos e entre esses e o sobrenatural.

Nas sessões de cura xamânica, por exemplo, a cachaça induz a um estado alterado de consciência que facilita a comunicação com os seres sobrenaturais. 
Essa função aproxima o significado de seu consumo ao do tabaco, já que o fumo sempre foi a substância psicoativa mais consumida nas sociedades indígenas sulamericanas para acessar o sobrenatural (Wilbert, 1987). Conforme vários autores já constataram, o fumo é fundamental para a mediação entre os xamãs e os seres sobrenaturais (Baer, 1992; Hill, 1992; Parker, 1997; Perrin, 1992; Pollock, 1992). Gallois ${ }^{7}$ trabalha com a hipótese de que a cachaça teria sido agregada ao ritual de cura para atuar junto com o fumo, ambos funcionando como caminho dos espíritos e elo de comunicação entre domínios diferentes, associação essa que também se verifica entre os grupos do Uaçá. A autora apoia-se em dados etnográficos obtidos entre xamãs indígenas (wajãpi e outros) que consomem destilados nas sessões de cura, no Camopi e em Saint Georges, ambos na Guiana Francesa.

Se a hipótese de Gallois está correta, uma possibilidade que esclareceria a incorporação do destilado no ritual xamânico indígena, tanto do Uaçá quanto da região das Guianas, seria pensar do seguinte modo: já que as agressões xamânicas são provocadas por agentes externos, a cachaça - bebida de não índio e comprada na cidade - seria uma forma do xamã se situar sociológica e simbolicamente no lugar do estrangeiro, e de lá realizar corretamente a etiologia e a terapia, reiterando, assim, a eficácia das práticas xamânicas. Isso indicaria que o consumo da cachaça nesse contexto possibilita abarcar o exterior e domesticar o 'de fora', evidenciando o caráter multilocal das relações de troca que sustentam a vida social na região das Guianas (Gallois, 2005).

Além de acesso ao sobrenatural, a cachaça pode ser utilizada para realizar o diagnóstico durante as sessões de cura xamânica. ${ }^{8}$ Nesses momentos, além de ingerir a cachaça, o xamã aplica a bebida no corpo do doente, enquanto canta e fuma. Como se sabe, durante as sessões xamânicas procura-se a etiologia da doença para identificar corretamente a origem do problema, por isso é possível pensar o uso da cachaça como mais um instrumento diagnóstico que se soma ao fumo e às cantarolas.

Simões Paes, na mesma ocasião, também observou que durante a sessão foi servido caxiri para o xamã e para a pequena plateia constituída de familiares do doente. Normalmente não se utiliza caxiri nessas situações. Naquela sessão específica, a presença do caxiri poderia ser esclarecida pelo fato de o oficiante terse tornado xamã recentemente e ter organizado um Turé na aldeia. Assim, o caxiri servido teria sido preparado, a princípio, para o Turé e, na ocasião da sessão de cura, cumpriria um papel auxiliar no diagnóstico à semelhança do fumo e da cachaça.

Mas então qual seria a diferença do caxiri em relação à cachaça no acesso ao sobrenatural? O caxiri tem uma dimensão coletiva, é produzido em grandes quantidades, exige doação de mandioca, preparação do beiju, um dono de festa, e é a bebida por excelência solicitada ao xamã pelos seres sobrenaturais durante o Turé, exceção feita aos Galibi Kali'na. Caxiri e Turé são praticamente indissociáveis. 
É possível haver caxiri sem Turé, mas Turé sem caxiri não. O agradecimento organizado pelo xamã nada mais é que a oferta da festa (Turé) e da bebida (caxiri). Beber, dançar e cantar representam oferendas. O caxiri consumido na festa vai para o outro mundo, morada dos karuãna (seres sobrenaturais com os quais o xamã tem contato durante as suas viagens oníricas). Quanto mais caxiri for consumido, quanto mais animada for a dança, mais intenso será o sentido de agradecimento.

Os povos indígenas do Uaçá não fazem associações explícitas entre o caxiri, o sêmen, a fermentação e a gestação, mas observando com atenção os protocolos que presidem a preparação e o consumo da bebida, vê-se que ela é carregada de significados.

O caxiri, metaforicamente, se assemelha ao sêmen. Durante o Turé, dentro do espaço cerimonial, laku (do francês, la cour, o pátio, em português), a bebida é servida preferencialmente por mulheres jovens, chamadas em patoá de ren (do francês, reines, rainha). Assim, ao contrário do sêmen, que vai dos homens para as mulheres, o caxiri percorre o caminho no sentido inverso, indo delas para eles. O caxiri estufa no estômago, empanturra, deixa a barriga inchada como se eles estivessem 'grávidos'. Nesse caso, é como se as mulheres inseminassem os homens, invertendo a lógica da concepção. A esse respeito, entre os Araweté, Viveiros de Castro (1986) refere-se à cauinagem como um momento no qual as mulheres servem os homens, inchando os dançarinos de cauim até que fiquem barrigudos como as gestantes. É um processo de 'inseminação artificial' em que o cauim emerge como uma espécie de 'sêmen feminino', conclui o autor.

No Uaçá, assim como em toda a região das Guianas, a fabricação do caxiri é um trabalho essencialmente feminino, sendo, inclusive, parte fundamental dos preparativos de casamento de uma mulher saber preparar a bebida. Durante o preparo do caxiri é comum que as meninas mais jovens fiquem por perto para aprenderem. Também não são explícitas, entre as populações do Uaçá, as associações simbólicas entre a fermentação do caxiri e a gestação, mas os mesmos paralelos simbólicos traçados entre o sêmen e o caxiri podem ser feitos entre a sua fermentação e a gestação quando se observam as regras de produção da bebida.

Tanto a gestação quanto a fermentação do caxiri são realizadas pelas mulheres, conferindo-lhes um papel de transformadoras de matérias-primas. No primeiro caso, de sêmen em criança, já que, é preciso esclarecer, a maioria dos povos indígenas brasileiros sustenta que o feto precisa ser fabricado por meio do fornecimento de um aporte constante de sêmen paterno durante os primeiros meses de gestação. Um só ato sexual não basta para que a concepção e a gestação se completem. As cópulas sucessivas nos primeiros meses de gravidez 'aquecem' o feto, o que é fundamental para a boa gestação. 
No segundo caso, em que as mulheres transformam, pela mastigação, a mandioca ou o milho cozido em caxiri fica ainda mais explícito o papel feminino de transformadoras de matérias-primas. No caso do Uaçá, as mulheres não mastigam a mandioca cozida, mas preparam os beijus que, juntamente com caldo de canade-açúcar, batata roxa, macaxeira, tucupi e água, passam alguns dias fermentando em potes de barro especiais. Do mesmo modo que o feto precisa ser 'aquecido' por meio de cópulas sucessivas para ter uma boa gestação, um 'caxiri do bom', como dizem os índios, exige uma fermentação adequada, que, por sua vez, liberando calor, 'coze' a bebida.

Durante a preparação do caxiri, 'ninguém pode mexer nele, ninguém pode olhar', só as mulheres que estão preparando a bebida. Entretanto, em agosto de 2005, na aldeia Galibi-Marworno, localizada na altura do Km 90 da estrada BR-156, a antropóloga Lux Vidal e o videomaker Francisco Paes conseguiram permissão para filmar e fotografar os preparativos do caxiri. Puderam registrar que, depois que todos os ingredientes necessários para a fabricação do caxiri tinham sido acondicionados no pote de barro, as mulheres colocaram dentro de uma cuia uma pequena quantia do próprio caldo que iria fermentar, além de algumas poucas folhas de caju. Em seguida, a cuia foi emborcada no fundo do pote com todos esses ingredientes. Todo esse procedimento é ritualizado e foi acompanhado de um canto, 'um canto do pajé', e a cuia no fundo, segundo as mulheres, é "como o karuãna do caxiri". Quando o caxiri começasse a fermentar e a borbulhar, a cuia deveria ir do fundo do pote para a superfície, sendo esse um indicativo de que o caxiri estava bom. E a recíproca também era válida, se a cuia não subisse, o caxiri não era bom.

Ao dizer que a cuia no fundo do pote é "como o karuãna do caxiri", inevitavelmente um espaço se abre para se pensar sobre o estatuto simbólico da bebida, na relação dos povos com o sobrenatural, para além de tão somente um veículo de acesso ou presente para os seres sobrenaturais. O caxiri, ele mesmo, seria um próprio karuãna, como também são karuãna uma série de animais e árvores. Os xamãs do Uaçá afirmam que entre o mundo onde vivemos e o mundo onde vivem os seres sobrenaturais, cuja designação genérica é de bichos, há uma relação de equivalência, na medida em que os seres do 'outro mundo', também designado de 'fundo', 'fundo das águas', 'fundo do mato' ou 'embaixo do sol', são gente como nós. Eles realizam festas, bebem caxiri e quando vêm passear no mundo onde nós seres humanos vivemos, esses bichos 'vestem uma capa' que lhes dá a forma específica como os vemos, ou seja, o bicho cobra veste-se de cobra, os bichos aves trajam penas, os bichos animais cobrem-se de pelos (Dias, 2001). Assim, se a cuia no fundo do pote é como se fosse o karuãna do caxiri, certamente, no 'outro mundo', o caxiri também é um karuãna. São seres sobrenaturais que fazem parte do repertório de cantos do xamã que, quando canta para chamá-los, nas sessões de cura ou no Turé, eles se apresentam. 
Diferenças à parte, a cachaça e o caxiri são equiparados na prática e no pensamento indígena, na medida em que os próprios grupos definem os estilos de consumo e as possibilidades de comunicação que as bebidas estabelecem entre os humanos e o mundo sobrenatural.

Tal equiparação surge de maneira bastante elucidativa em um mito palikur, contado a Lux Vidal, em 2002, durante uma estadia para pesquisa de campo. É importante frisar que mito e história na região do Uaçá são dois aspectos da realidade intimamente imbricados.

Diz a história que no lugar chamado Ponta dos Índios, ${ }^{9}$ isso lá pelos anos 1930 ou 1940, ao descer de um barco, chamado indiferentemente pelo índio palikur de iate ou vapeur, uma senhora crioula, ${ }^{10}$ meio gorda, caiu na água e foi subitamente apanhada e levada para o fundo por um monstro, algo parecido com a Cobra Grande. Nem os gendarmes nem os pompiers guianenses chamados às pressas conseguiram reavê-la. ${ }^{11}$

Os índios convocaram então um pajé para acabar com o bicho. O pajé palikur aceitou o desafio, reuniu os seus karuãna, os zami, enfim, seus auxiliares do 'outro mundo', pedindo a eles que providenciassem martelos, pregos, uma placa de cobre e um abismo. Bem-sucedidos em eliminar o monstro, os karuãna informaram que apenas pediriam a bebida como forma de pagamento por terem jogado o monstro no abismo e depois lacrado com placa de cobre. ${ }^{12}$ Os franceses, meio constrangidos, confessaram não possuir a 'bebida de índio', ou seja, o caxiri. O pajé passou a informação a seus auxiliares do 'outro mundo', e eles responderam que, tudo bem, aceitariam a bebida dos franceses. Mas perguntaram quanto tempo iria demorar a entrega da bebida. Os franceses responderam: 'c'est tout de suite', ou seja, é para já, era apenas abrir as garrafas e servir, o que deixou os karuãna muito alegres.

Nesse mito, a solicitação do caxiri por parte dos karuãna representa o pagamento pelos serviços prestados. Quando os seres sobrenaturais aceitam a cachaça no lugar do caxiri, torna-se evidente a possibilidade de a cachaça e o caxiri se equipararem na prática e no pensamento indígena e o quanto ela está enraizada na cosmologia dos grupos.

\section{Embriaguez reprovável}

As percepções indígenas dos inconvenientes trazidos pelo consumo de bebidas alcoólicas referem-se fundamentalmente a certo descontrole sobre quem, quando e como se bebe durante as festividades e atividades cotidianas. Os efeitos negativos são prioritariamente em relação às bebidas compradas nas cidades (cachaça, conhaque, vinho, cerveja, uísque), mas mesmo no consumo do caxiri há excessos considerados indesejáveis. Isso pode ocorrer durante o Turé quando a 
pessoa namora ou briga dentro do laku. É preciso, então, cumprir o lamã (do francês l'amende, a multa), castigo que consiste em ingerir uma grande quantidade de caxiri, estipulada pelo xamã, que empanturra a pessoa. No caso de não conseguir tomar toda a bebida, outras pessoas podem auxiliar.

Nas palavras dos índios, os inconvenientes do consumo excessivo de cachaça convergem para as seguintes questões: provoca desunião e brigas; acidentes; diminui a produtividade dos grupos; faz o índio perder/esquecer a sua cultura; quando se bebe muita cachaça o caxiri é deixado de lado.

Nas palavras de um cacique palikur, a causa dos problemas com a bebida "é que muitos índios não sabem beber porque querem encher a barriga de cachaça como se fosse comida". Nota-se, no comentário, que as bebidas alcoólicas estão associadas aos alimentos, assim o limite de seu consumo seria o do próprio estômago. De qualquer forma, já há uma percepção entre os índios de que, em relação à cachaça, é preciso outra atitude, porque tomar a aguardente até o ponto de 'encher a barriga', como se fosse comida, é não saber beber, trazendo como consequência os inconvenientes apresentados.

Embora não estejam presentes no discurso indígena, três conjuntos de motivos parecem determinantes para compreender os estilos indesejáveis de beber: 1) a cachaça comprada na cidade tem um poder de embriaguez muitas vezes maior que o do caxiri, e seu consumo é cada vez mais frequente durante os trabalhos de roça coletivos realizados com comida e bebida, nas festas de santo, assembleias políticas e Turé;

2) presença de estilos de consumo aprendidos nas cidades: bebe-se nos fins de semana, no final de um dia de trabalho, quando estão na cidade para fazer compras ou receber salários, dias dos pais e das mães, em aniversários, datas cívicas, feriados em geral, Finados, Natal, Ano Novo, Páscoa, em velórios e enterros etc.;

3) um fato que chama a atenção quando se observam os grupos do Uaçá beberem, caxiri ou outra bebida alcoólica qualquer, é que bebem sempre visando ao fim da bebida, especialmente quando estão nas aldeias. Em suas próprias palavras: "é beber até zerar".

Sobre esse terceiro conjunto de motivos vale a pena estender-se um pouco mais tentando responder à pergunta: por que beber até zerar?

De um ponto de vista cosmológico, esse estilo de consumo proviria do Turé. O caxiri consumido durante o ritual é uma forma de os povos agradecerem aos seres sobrenaturais pelas curas concedidas. Quanto mais se dança, canta e bebe, quanto mais animada for a festa, maior será a gratidão. Consumir caxiri em grandes quantidades seria um gesto de benevolência para com os seres 
sobrenaturais. A recusa do consumo ou a sua ingestão parcimoniosa indicaria certa ingratidão e, também, uma recusa à sociabilidade. É como se, metaforicamente, quem bebesse não fosse o índio, mas os karuãna. De fato os índios dizem que os karuãna "se servem à vontade" durante o Turé.

Vidal (2007) mostra, ainda, que o consumo de caxiri apazigua as tendências canibais dos seres monstruosos do 'outro mundo'. No mito da Cobra Grande, o macho Cobra quer devorar o menino índio que após cair em um buraco veio parar em seu hábitat, no 'fundo'. A Cobra fêmea, para impedir esse ato, enche a barriga do marido com grandes quantidades de caxiri guardado em potes de barro, até ele ficar quieto e aceitar a presença do menino.

De mais a mais, conforme esclarecido anteriormente, embriagar-se não é uma questão moral. Desde que os protocolos da boa convivência sejam observados, não há por que se envergonhar de ficar de porre, ainda mais numa ocasião apropriada como o Turé. Existe momento para tudo, e o momento do porre precisa ser respeitado. Ele é uma instituição, um estado socialmente reconhecido e esperado. Isso é de tal maneira possível que um índio em estado inteiramente sóbrio, às vezes, recusa-se a marcar uma entrevista ou reunião para uma determinada data ou momento (sábado à tarde, por exemplo) sabendo de antemão que estará de porre e, assim, sem condições de atender ao pedido. Geralmente um homem em estado de embriaguez, porre, retira-se em sua casa e deita no chão, o que os índios definem com cuvê so vin (cuver son vin, em francês). ${ }^{13} \mathrm{Na}$ ocasião de uma visita, quando for o caso, a esposa informa tranquilamente que o marido não pode atender porque está de porre, e pede para voltar em outro momento.

O que parece ocorrer é que, embora os índios façam distinções simbólicas entre o consumo do caxiri durante o Turé e o de outra bebida em circunstâncias sociais diferentes, beber 'até zerar' persiste como um padrão nos vários outros momentos da vida social. ${ }^{14}$ Por mais 'forte', isto é, alcoólico que um caxiri possa ser, seu poder de embriagar nunca chega próximo do poder dos destilados como a cachaça. O resultado dessa combinação é a embriaguez bastante acentuada e, por vezes, considerada imprópria para o momento, como, por exemplo, os casos de xamãs que tomam uma quantidade tal de cachaça durante o Turé, que os incapacita de conduzir controladamente a dança, com a animação e o entusiasmo apropriados durante toda noite até o amanhecer.

\section{Considerações finais}

As bebidas alcoólicas são absolutamente presentes na vida social dos povos indígenas do Uaçá. São consumidas nas atividades produtivas, nas festas de santo, nos rituais xamânicos, nas reuniões, nas celebrações e no lazer. Assumem o papel de meios de acesso ao sobrenatural, de presentes aos seres do 'outro mundo', 
de veículo de reciprocidade e agente motivador nos trabalhos de roça, de veículos de feitiços, de causas de doenças no caso da cachaça, de agentes etiológicos e terapêuticos nas sessões de cura.

Existe um estilo de consumir as bebidas alcoólicas no Uaçá que se caracteriza por uma ética da imoderação, do exagero e da renúncia da parcimônia. Enquanto houver bebida disponível, ela deve ser consumida inteiramente, "até zerar", como dizem. Esse modo de beber permeia todos os contextos socioculturais, e como a bebida está presente na maioria deles, a embriaguez se torna bastante comum e intensa. O 'porre', como eles mesmos denominam a embriaguez, é uma instituição social, reconhecida e valorizada, chegando ao ponto de programar os compromissos em função dele.

Para compreender toda a riqueza de significados envolvida no ato de beber, é preciso situar-se numa perspectiva em que as bebidas são vistas como parte integrante da vida social. Isto não significa, evidentemente, ignorar os aspectos dissociativos que o uso excessivo de bebidas destiladas provoca entre os povos indígenas. Privilegiar uma abordagem social e coletiva do consumo de bebida, ao invés de uma abordagem que foque o indivíduo, é caminho mais adequado para compreender de que modo as bebidas alcoólicas no Uaçá motivam o trabalho e intensificam sobremaneira a sociabilidade entre as famílias e entre os grupos, assim como para perceber que as interpretações indígenas do excesso indicam que seu valor é ambivalente. Consumir muita bebida não diz se a atitude é moralmente aceita ou reprovável. Ingerir bebidas alcoólicas imoderadamente pode ser culturalmente adequado ou inadequado, e são apenas os contextos específicos de consumo que definem de que excesso se trata e com qual sinal qualificá-lo.

A noção de excesso para o consumo de bebidas alcoólicas entre os povos indígenas do Uaçá é ambivalente. Consumir grandes quantidades, seja de caxiri ou de qualquer outra bebida comprada na cidade, não é interpretado como um problema. Existe uma noção culturalmente construída de quantidade, de situações e espaços adequados para beber, de atitudes que podem ser tomadas e outras que devem ser evitadas. O consumo torna-se indesejável na medida em que não se atende às expectativas sociais da boa convivência, de participação condizente nas atividades rituais e produtivas, ou quando há envolvimento em acidentes e desavenças. O consumo de bebidas alcoólicas exerce um papel fundamental na vida dos povos do Uaçá, já que, no limite, possibilita a continuidade da vida social.

Tais considerações permitem um diálogo com as noções biomédicas acerca do que vem a ser um consumo normal, abusivo e patológico de bebidas alcoólicas. Se, em uma perspectiva biomédica, o consumo de álcool em grande quantidade é considerado um problema de saúde, para os povos indígenas essas questões são muito mais complexas e dizem respeito a formas específicas de relações sociais e cosmológicas. Exceção feita aos Palikur, para os demais povos do Uaçá, o consumo 
de bebidas alcoólicas também produz estados de consciência culturalmente valorizados.

Entretanto, metaforicamente, o excesso também pode significar doença entendida como um desequilíbrio biofísico, social e simbólico, ou comportamento indesejável que pode prejudicar as relações sociocósmicas quando ultrapassa ou rompe os limites do socialmente prescrito (Buchillet, 1991). O excesso como descontrole é percebido quando há ruptura de equilíbrio nos laços de sociabilidade. Assim, as percepções específicas do que seja descontrole e suas estratégias de contenção diferem do ponto de vista da medicina ocidental.

Notas

1 Este capítulo é uma versão revisada de: Dias, L. F. Usos e abusos de bebidas alcoólicas segundo os povos indígenas do Uaçá. In: LABATE, B. C. et al. (Orgs.). Drogas e Cultura: novas perspectivas. Salvador: Editora Ufba, 2008. Texto republicado com autorização do autor e da editora.

2 Nesse caso, como em muitas outras partes deste capítulo, prefiro usar o termo 'porre', que os próprios índios usam, a embriagado, porque parece refletir o sentido nativo do conceito, isto é, um momento previsto e padronizado de comportamento.

3 Bebida alcoólica fermentada preparada com beijus e uma variedade de mandiocas. Para fermentar, o beiju e a mandioca são colocados num vaso de barro, juntamente com pedaços de batata, geralmente de cor roxa, e cana-de-açúcar, onde passam alguns dias fermentando.

4 O etnônimo Paricura é ainda hoje utilizado por outras etnias para referirem-se aos Palikur.

5 Festa organizada pelo xamã para agradecer aos seres sobrenaturais (karuãna) pelas suas intervenções terapêuticas. Durante a festa, a eles são oferecidas grandes quantidades de caxiri.

6 Em relação aos Galibi Kali'na, que residem na Guiana Francesa, não disponho de dados a respeito.

7 Comunicação pessoal, 2003.

8 O material audiovisual, produzido por Simões Paes, em 2003, ainda não tem título, mas está disponível no Laboratório da Imagem e do Som (Lisa), do Departamento de Antropologia da Universidade de São Paulo.

9 Extremo norte do Brasil, próximo à foz do rio Oiapoque.

10 O termo faz referência às línguas mistas que surgiram a partir do contato entre o francês, o português, as línguas nativas indígenas e as faladas pelos ex-escravos de origem africana. Também é utilizado para designar pessoas de pele escura (negros), como é o caso específico desta história.

11 Gendarmes e pompiers, em francês, significam, respectivamente, policiais e bombeiros, ou seja, seres sobrenaturais responsáveis pela guarda e proteção do xamã e dos que participam de seus rituais: sessões xamânicas e Turé. 
12 Essa técnica aparece em outras narrativas.

13 Literalmente a expressão quer dizer 'cozer a bebedeira', ou seja, esperar o 'porre' passar.

14 Léry (1994 apud Sztutman, 2004), referindo-se aos antigos Tupi da Costa, nota o mesmo padrão de consumo: era necessário beber em excesso até findar todo o conteúdo da bebida. Era um código decisivo de comportamento e deveria ser seguido por todos participantes adultos da festa.

\section{Referências}

BAER, G. The one intoxicated by tobacco. In: BAER, G. G LANGDON, E. L. M. (Eds.). Portals of Power. Albuquerque: University of New Mexico Press, 1992.

BUCHILLET, D. A antropologia da doença e os sistemas oficiais de saúde. In: BUCHILLET, D. (Org.). Medicinas Tradicionais e Medicina Ocidental na Amazônia. Belém: MPEG, CNPq, Cejup, UEP, 1991.

CAPIBERIBE, A. Os Palikur e o Cristianismo, 2001. Dissertação de Mestrado, Campinas: Departamento de Antropologia, Universidade de Campinas.

CRITCHLOW, B. The powers of John Barleycorn: beliefs about the effects of alcohol on social behavior. American Psychologist, 41, 7: 751-764, 1986.

DIAS. L. F. Uma Etnografia dos Procedimentos Terapêuticos e dos Cuidados com a Saúde das Famílias Karipuna, 2001. Dissertação de Mestrado, São Paulo: Departamento de Antropologia, Universidade de São Paulo.

DOUGLAS, M. A distinctive anthropological perspective. In: DOUGLAS, M. (Ed.). Constructive Drinking: perspectives on drink from anthropology. Cambridge: Cambridge University Press, 1987.

GALLOIS, D. T. Introdução: percursos de uma pesquisa temática. In: GALLOIS, D. T. (Org.). Sociedades Indígenas e suas Fronteiras na Região Sudeste das Guianas. São Paulo: Humanitas, FFLCH/USP, 2005.

GUSFIELD, J. R. Passage to play: rituals of drinking time in American society. In: DOUGLAS, M. (Ed.). Constructive Drinking: perspectives on drink from anthropology. Cambridge: Cambridge University Press, 1987.

HARRIS, M. Cultural Materialism: the struggle for a science of culture. New York: Vintage Book, 1980.

HEATH, D. B. International Handbook on Alcohol and Culture. London: Greenwood, 1998.

HILL, J. D. A musical aesthetic of ritual curing in the Northwest In: BAER, G. G LANGDON, E. J. M. (Eds.). Portals of Power. Albuquerque: University of New Mexico Press, 1992.

KATZ, S. H. G VOIGT, M. M. Bread and Beer. Expedition, 28: 23-34, 1986.

LÉRY, J. Histoire d'un Voyage Faict en la Terre du Brésil. Texte établi, présenté et annoté par Frank Lestringant. Paris: Livre de Poche, 1994. 
MACANDREW, C. G EDGERTON, R. D. Drunken Comportment: a social explanation. Chicago: Aldine, 1969.

MANDELBAUM, D. G. Alcohol and culture. Current Anthropology, 6(3): 281-293, 1965.

MARSHALL, M. (Ed.). Beliefs, Behaviors and Alcohol Beverages: a cross-cultural survey. Ann Arbor: The University of Michigan Press, 1979.

MCDONALD, M. (Ed.). Gender, Drink and Drugs. Oxford: Berg, 1994.

MILAN, J. R. G KETCHAM, K. Alcoolismo: mitos e realidade. São Paulo: Nobel, 1986.

PARKER, R. Políticas, Instituições e Aids: enfrentando a epidemia no Brasil. Rio de Janeiro: Jorge Zahar, Abia, 1997.

PERRIN, M. The body of the guajiro shaman. In: BAER, G. G LANGDON, E. J. M. (Eds.). Portals of Power. Albuquerque: University of New Mexico Press, 1992.

POLLOCK, D. Gender, power and knowledge. In: BAER, G. G LANGDON, E. J. M. (Eds.). Portals of Power. Albuquerque: University of New Mexico Press, 1992.

RUDGLEY, R. The Alchemy of Culture: intoxicants in society. London: British Museum Press, 1993.

SZTUTMAN, R. Kawewi pepique: les caouninages anthropophages des anciens TupiGuarani In: ERIKSON, P. (Ed.). La Pirogue Ivre: bières tradicionalles en Amazonie. Saint Nicolas-de-Port: Musée Français de la Brasserie, 2004.

VIDAL, L. B. A Cobra Grande: uma introdução à cosmologia dos povos indígenas do Uaçá e Baixo Oiapoque - Amapá. Rio de Janeiro: Museu do Índio, 2007.

VIVEIROS DE CASTRO, E. Araweté: os deuses canibais. Rio de Janeiro: Jorge Zahar, Anpocs, 1986.

WILBERT, J. Tobacco and Shamanism in South America. New York, London: Yale University Press, 1987. 


\section{Tomar uma Fuga: metáforas sobre o contexto social e econômico da alcoolização pankararu}

Existe uma relação de identidade entre os povos indígenas contemporâneos do Nordeste brasileiro e a condição camponesa. Esses grupos estão entre os primeiros na história do Brasil, desde o século XVI, a manter contato com os colonizadores europeus. Assim, foi tecida uma trama de longa duração envolvendo extermínio, escravidão, aldeamentos, casamentos interétnicos e caldeamento cultural. Apesar de camponeses, continuam índios (Oliveira, 1976).

A etnia Pankararu, desde a década de 1940, apareceu oficialmente com o antigo Serviço de Proteção aos Índios no Sertão do Submédio São Francisco, em Pernambuco, como um grupo fenotipicamente misturado e inserido na lógica do aludido campesinato indígena. Explicações antropológicas surgem até hoje: transfiguração (Ribeiro, 1996), reelaboração (Oliveira,1994) ou reemergência étnicas (Arruti, 1999).

Nessa população, como em quase todo o mundo, são ingeridas substâncias químicas que alteram o estado de humor ou da consciência. Dentre elas, o álcool etílico é a mais antiga e importante. Hipóteses procuram explicar que essas bebidas teriam surgido em diversos momentos da história e que, no caso da América do Sul, resultaram da influência indireta do desenvolvimento agrícola dos povos maias na América Central (Guelbaly G Guelbaly, 1981 apud Fortes G Cardo, 1991).

Entre os autóctones no Brasil, já havia a produção e consumo de um etílico próprio. Jean de Léry, viajante europeu, relatou em 1557 que, nos contatos dos franceses do huguenote Conde de Villegagnon com os nativos Tubinambás, na cidade de São Sebastião do Rio de Janeiro, era costume o uso do cauim (ka'wi em tupi). Tratava-se de uma bebida turva e espessa, com gosto semelhante ao do leite azedo. O preparo demandava fervura, mastigação e reserva do milho ou da mandioca em potes de barro, onde a pasta ficava submetida a um processo de fermentação (Léry, 1967)

Eram obedecidas regras rituais, entre elas as antropofágicas. Bebiam e comiam por três dias seguidos, geralmente em grupos. Durante sua permanência no Brasil, Léry (1967) não encontrou casos de melancolia entre os povos indígenas. 
Observou que eles cantavam, dançavam, assobiavam e se incitavam uns aos outros, em termos de brincadeiras, para que tivessem comportamentos viris.

Outro viajante, Hans Staden, nos anos de 1548 a 1557, igualmente escreveu que entre os Tupinambás, nos costumes para beber, é "raro observar alguma briga nesses momentos. São muito prestativos entre si, portanto, quando alguém tem mais comida do que outro, dá um pouco a este" (Staden, 1999: 149).

O padrão de consumo modificou-se com a presença europeia, e principalmente portuguesa, pelo acesso a bebidas desconhecidas e com maior teor alcoólico, como o vinho, a cerveja e a cachaça (Fortes G Cardo, 1991).

O alcoolismo entre indígenas foi considerado por Ribeiro (1991) como um problema decorrente do que chamou de 'etnocídio' ou seja, um extermínio cultural induzido pela burocracia oficial protecionista e também pela ação missionária. As outras pestes seriam o genocídio - progressivamente reduzido desde os tempos do marechal Cândido Rondon (1865-1958) - e as próprias epidemias varíola, sarampo, catapora, difteria, gripe, coqueluche e tuberculose.

O papel mediador das bebidas alcoólicas no genocídio indígena pelos colonizadores portugueses é ilustrado por um acontecimento que se sucedeu na capitania de Itamaracá, depois da morte de Duarte Coelho ocorrida em 1554, no governo de Jerônimo de Albuquerque. Este novo governador tinha a intenção de expulsar os índios da várzea do Capibaribe para o sul dos Montes Guararapes, fazendo prosperar a cultura da cana-de-açúcar. Na época, as populações nativas, principalmente os Tupis do litoral, estavam agitadas e temerosas de novos avanços dos portugueses, atacando viajantes que iam de Olinda a Igarassu. Havia receio de uma nova guerra, como a ocorrida em 1548.

Na ocasião várias tribos e nações vizinhas foram convidadas para uma festa pelos portugueses, quando se distribuiu muito vinho. Os índios excederamse no consumo, foram acusados pelos ataques, começando a haver insultos mútuos. Essa provocação foi um álibi para um confronto bélico, iniciado pelo governador, que conquistou a fértil barga do Capibaribe (Andrade, 1962).

Importante comentar que as complicações individuais e coletivas ocasionadas pelo consumo de bebidas alcoólicas dependem menos delas em si mesmas do que das formas de consumo, sejam eventuais ou frequentes, moderadas ou excessivas; ou das respectivas funções, sejam festivas, terapêuticas, religiosas, culinárias, entre outras.

Portanto, é lógico pensar que existem padrões de consumo considerados normais ou patológicos, ou então, benéficos ou maléficos. Essa relativização é enfocada por Menéndez (1983: 248) por meio do conceito de processo de alcoolização, entendido como um somatório das "funções e consequências positivas e negativas que cumpre a ingesta de álcool para os conjuntos sociais estratificados e que implica somente potencialmente o problema da enfermidade mental". 
Essa é uma noção que surgiu em estudo do pesquisador mexicano sobre a produção bibliográfica da socioantropologia latino-americana, entre as décadas de 1970 e 1980, em torno de um hábito que 'também' pode apresentar uma face de doença. Além dos estudos biomédicos e epidemiológicos centrados nos distúrbios e agravos do processo de alcoolização, são descritos como funções positivas os seguintes aspectos: 1) reforço para a segurança dos sujeitos e dos grupos diante das ameaças de um mundo vazio; 2) mitigação da ansiedade decorrente dos processos de aculturação e de pauperização; 3) estimulador da coesão grupal através das ações de trocas envolvidas; 4) operador de transformações imaginárias principalmente no espaço coletivo das festas ou dos cultos de possessão -, colocando entre parênteses uma situação opressiva estrutural; 5) facilitador da hegemonia masculina numa situação desfavorável de trabalho urbano ou de campesinato; 6) instrumento de evasão e de criação de espaços próprios de ação, por meio da formação de microgrupos (Menéndez, 1983).

O sentido original do substantivo evasão está relacionado com um movimento de fugir de algum lugar. Ao se acrescentar o adjetivo 'alcoólica' está se abordando um determinado uso dos etílicos, que propicia alteração da consciência dos sujeitos, fazendo emergir um estado psíquico de fuga de uma condição objetiva e subjetiva de sofrimento humano em um contexto específico de campesinato indígena. A compreensão mais fidedigna do significado do consumo etílico, na perspectiva dos sujeitos da etnia Pankararu, ocorre através de um olhar etnográfico do observador e autor, participando do dia a dia na aldeia, e registrando em seu diário de campo não apenas o uso dessas bebidas, mas a escassez material vinculada a um adverso cenário social e econômico.

Assim, será necessário, em primeiro lugar, um enfoque antropológico do que seja economia, o que resgata autores como Bernardi (1988) para quem a ordem econômica encontra-se profundamente interconectada com a ordem política e social, o que em certa medida relaciona-se com o sentido maussiano de fato social total (Oliveira, 1979). Seguindo essa tradição teórica, Lévi-Strauss (1974) fundamenta a vida cultural em três tipos básicos de troca: as econômicas, as linguísticas e as de parentesco.

Nesse paralelo com as interações linguísticas, cumpre destacar a relevância da interpretação simbólica do processo de alcoolização, percebendo-se que, entre as diversas possibilidades de produção de sentidos no nível do fenômeno discursivo, existe uma engenharia semântica na construção das metáforas (Oliveira, 1997).

Podem ser discutidas três funções em torno desse tropo: uma, estética, representada principalmente por determinadas imagens construídas no discurso literário; outra, persuasiva, vinculada às estratégias de convencimento presentes nos discursos morais, políticos, jurídicos, midiáticos, entre outros; e, por fim, uma cognitiva, permitindo explicar por meio de comparações um determinado domínio do conhecimento por outro domínio (Charaudeau G Maingueneau, 2006). 
Dessa forma, torna-se necessária uma descrição etnográfica do cenário social e econômico da etnia Pankararu no estado de Pernambuco (Acioli, 2002), que permita a visualização de um contexto para a leitura de um determinado texto: a expressão local 'tomar uma fuga', de sentido polissêmico, a ser explorada a seguir.

\section{O cenário social e econômico da etnia Pankararu}

A etnia Pankararu, segundo o Atlas das Terras Indígenas do Nordeste (Peti/Museu Nacional, 1993), localiza-se no estado de Pernambuco em 14.294 hectares de área indígena, confirmados em 1940 pelo antigo Serviço de Proteção aos Índios (SPI). Foram homologados 8.100 hectares e demarcados 6.194 hectares, ao longo dos anos, em torno de um perímetro de 36 quilômetros.

De acordo com a Base de Dados do Estado (Pernambuco, 2007), uma população de 6.404 índios Pankararu habita uma área circunscrita a três municípios, contando cada um deles com população que varia de 15 a 30 mil habitantes. São eles: Tacaratu (6 Km de distância), Jatobá (8 km de distância) e Petrolândia (16 km de distância). O clima da área é tropical semiárido, tendendo a seco pelas irregularidades da ação das massas de ar, provocando muito calor no verão e muito frio no inverno, de acordo com a percepção local dos moradores.

As estradas de barro com erosões, várias intransitáveis nos períodos de chuva, tornam o acesso à área muito difícil. O estorvo sugere que a atenção política à comunidade apresenta-se historicamente precária.

Ainda com base no Banco de Dados do Estado (Pernambuco, 2007), a área indígena localiza-se a 412 quilômetros de distância da capital pernambucana e nela existem 28 aldeias, 1.595 domicílios e 1.757 famílias, distribuídas entre as serras do Barrocão, do Cruzeiro e do Morcego.

É uma paisagem de serras e vales, onde se espalham fruteiras com pinhas, mangas, bananas, melancias, entre outras. Roças são plantadas nos terrenos planos próximos das respectivas elevações entre as serras. A produção depende da chuva e da estiagem.

Essas características do espaço físico são descritas na denominação nativa em língua kariry: "Tuaçá de Ginpankã Tamkauaukó Pankararu". Ela pode ser traduzida da seguinte maneira: "Entre serras e cabeças porto de cana brava".

O terreno alagadiço em boa parte da área, por conta de lençóis freáticos que formam cisternas naturais no subsolo, influenciou a denominação da principal aldeia pankararu: Brejo dos Padres.

No Brejo foram instalados o posto Indígena pelo SPI, no início da década de 1940, o cemitério, a Igreja de Santo Antônio, e, nesta aldeia com população mais numerosa são realizados importantes rituais da etnia. 
A religiosidade pankararu está demarcada pelo tempo dos rituais indígenas e pelo tempo dos rituais da Igreja católica. Os primeiros integram o que se chama de ciência dos mais velhos e fazem parte da crença de que os mortos não desencarnam, porém eles se encantam, formando um complexo de entidades chamadas 'encantados'.

A comunicação dessas entidades com os homens ocorre por meio de determinados sinais, entre eles assovios nas matas, que obrigam os transeuntes a serem 'donos' ou 'pais' de um determinado praiá. A condição de propriedade implica um estado de transe ritual em sujeitos que passam a incorporar essas entidades, apenas quando eles estão vestidos com determinadas fardas - termo que denota a influência de um imaginário militar - feitas de um chapéu, penacho, casaco, cinta e saia, todas confeccionadas com fibras do caroá (Neoglaziovia variegata), planta terrestre típica do Nordeste brasileiro, cujas folhas lineares são fibrosas garantindo resistência e durabilidade. Os sujeitos incorporados pelos encantados e vestidos de acordo com as regras rituais são denominados praiás. Eles dançam tocando uma flauta de bambu chamada gaita ou sacudindo um maracá que marca a batida do ritmo binário do Toré.

Essa dança apresenta-se como sagrada e circular, e nela estão presentes homens, mulheres, ambos sem estado de transe, e praiás caracterizados apenas por homens em estado de transe, muitas vezes reproduzindo sons da natureza como cantos de pássaros, o que confirma a identidade étnica do grupo.

A encarnação dos encantados na personagem dos praiás recebe vários nomes: Imburana, Pokodô, Cansanção, Capitão da Rima, Cordão, Menino, Vivim, Xumpunhum, Beija-Flor, Cordão Verde, Andorinha, Arapão, Zé Fogacho, entre outros. Dois se destacam nesse panteão: Mané Brabo, pelo estilo agressivo da sua dança, e Mestre Guia, que ocupa posição hierárquica superior, pois abençoa e é conselheiro de todos os outros.

Entre os rituais indígenas inclui-se o Menino do Rancho, que ocorre a partir do momento em que uma criança adoece e os familiares fazem promessa a um determinado encantado para que ela fique curada. A dramatização ocorre através de uma luta a ser travada entre dois grupos. Um deles, o dos padrinhos que defenderá a permanência do menino no 'mundo dos vivos', havendo no grupo apenas um praiá, exatamente aquele que é dono do encantado para quem a promessa foi feita. O segundo grupo é composto exclusivamente de praiás, cujos encantados que personificam lutam para levar a criança ao 'mundo dos que se encantaram'.

Para a realização do Menino do Rancho, há necessidade de recursos financeiros para o custeio do ritual, além das refeições para todos os convidados e participantes diretos. O almoço consta de guisado de carne de boi, arroz cozido com água e sal, farinha de mandioca e uma caneca de caldo de cana-de-açúcar. 
Entretanto, um dos familiares informou terem sido usadas seis caixas de aguardente durante esse dia de domingo - cada caixa contendo 25 garrafas. Portanto, esse novo dado, acrescentado posteriormente, partiu da lógica de que a aquisição, disseminação e consumo de bebidas alcoólicas em áreas indígenas, interditados pela vigente lei federal n. 6001/73 na época da etnografia, ao final dos anos 90, caracteriza os etílicos como substâncias ilícitas, sendo camuflada a respectiva presença em reuniões comemorativas.

Esse consumo, no caso do Menino do Rancho, está associado à energia, à proteção contra a dor e ao divertimento, não sendo registrados, dentro do espaço dos rituais religiosos, a existência de violência social.

Em termos do cenário econômico, em Brejo dos Padres os protagonistas são agricultores e comerciantes (pequenas mercearias e uma de porte médio) que vendem basicamente fiado. Nos vários roçados existem plantações de feijão de vários tipos, entre eles feijão-de-arranque (um tipo de feijão mulatinho), feijão-decorda (um tipo de feijão macassa) e o andu ou feijão-guando (um tipo de feijãobranco), além de batata-doce, macaxeira, milho, mandioca, capim e palma. Muitos moradores produzem tijolos de argila para a comercialização interna na área. A pesca e a caça são praticamente inexistentes. O trabalho assalariado não é frequente, salvo entre alguns funcionários públicos. Outra forma de remuneração ocorre com o pagamento de diárias, variáveis de 7 a 10 reais, na atividade agrícola ou na produção de tijolos, e também a alguns meeiros.

Uma característica que compromete a qualidade de vida dos Pankararu é o preço pago pela produção agrícola - 15 reais por um saco de 60 quilos de feijão -, o que estimula mais o consumo doméstico do que a comercialização. Entre as frutas, um cento de manga é vendido por 2 reais, um cento de pinha por 3, o que às vezes não cobre nem o preço do frete. A alternativa para a comercialização é a realização das feiras públicas nos municípios vizinhos, como a de Petrolândia, a mais importante, às sextas-feiras, e a de Tacaratu, aos sábados. Muitos animais, como vacas, bois e ovelhas, porcos, cabras e galinhas foram vendidos, por causa da necessidade. Diz uma idosa: "A gente não quer só feijão, quer o tempero também. A gente não quer comer com uma mão só".

Ficando os roçados próximos das encostas serranas, distantes das casas dos moradores de Brejo dos Padres, os homens acordam entre as 4 e 5 horas da manhã e se deslocam para o cuidado com a terra. Em alguns casos, é consumida cachaça como estimulante para o trabalho árduo, sendo a substância uma panaceia para os males do corpo e da alma.

Outra atividade explorada é a produção artesanal, com emprego de mão de obra predominantemente feminina. São confeccionados, em palha de ouricuri (Athea excelsa) e fibras de caroá (Neoglaziovia variegata), vassouras, sacolas, abanos e cestos; e, com o barro, panelas e fogareiros, sejam para o consumo doméstico ou para a venda. 
Diante desse cenário, como se contextualiza a alcoolização pankararu e qual a lógica e a semântica presentes no discurso de moradores sobre esse processo?

\section{Tomar uma fuga: metáforas em torno do processo de alcoolização pankararu}

D. Severina tem 68 anos de idade, é solteira e aposentada como servidora da saúde pela Fundação Nacional do Índio (Funai). Mora onde nasceu e se criou, Brejo dos Padres. Da época da infância, recorda-se de alguns mutirões realizados entre os moradores:

O pessoal dizia que tinha a construção de uma casa, pra tapar as paredes de barro. As mulheres e os homens iam buscar barro branco na serra. Era tudo unido como se fosse a casa deles. O carregamento era através de cantigas de roda ou de brincadeira. Quando tapava a casa tinha aquele almoço. Depois do almoço, o pessoal tomava uma fuga. Descansava bastante. $O$ restante do barro que sobrava, colocava no piso da casa e depois dançava o Toré. No mesmo instante, [a dança] servia como se os próprios pés das pessoas estavam compactando o solo pra formar o piso. (destaque do autor)

A expressão 'tomar uma fuga' é uma metáfora que no contexto do discurso de d. Severina significa 'repousar'. Entretanto, é importante ter em mente que as palavras podem ser polissêmicas. Orlandi (2007) alerta sobre os cuidados que se deve ter com a ilusão de que o sentido de uma palavra seja algo 'amarrado' e irredutível. Essa visão reducionista impossibilita compreender que não existe um sentido único, a priori e descontextualizado, seja ideológica ou historicamente, na produção discursiva.

Examinando o campo de sentidos do verbo 'repousar' - associado ao significado metafórico da expressão 'tomar uma fuga' -, podem ser encontradas as seguintes imagens: 1) descanso (vinculada ao sentido negativo do verbo 'produzir'); 2) alívio (associada ao verbo 'tranquilizar'); 3) morte (relacionada com a expressão 'estar sepultado'); 4) assentamento (vinculada ao verbo 'instalar'), entre outras (Houaiss G Villar, 2001: 2.432).

Desse modo, podem ser elaborados novos pressupostos de que a alcoolização esteja discursivamente construída com base em três sentidos metafóricos, presentes na expressão 'tomar uma fuga'. O primeiro corresponde aos modos tradicionais de consumo de bebidas alcoólicas como um momento de não produção econômica para muitos, seja nos fins de semana ou em ocasiões especiais. O segundo, como um processo migratório de viagens de idas e vindas para o sul do Brasil, como um alívio para as condições econômicas adversas da área indígena, mas desencadeador, muitas vezes, do sofrimento propiciado pelas doenças, entre 
elas o alcoolismo-doença e a própria morte. Por fim, a fixação de pontos de venda clandestina de bebidas alcoólicas como uma estratégia ilegal de atividade econômica, o que representa 'fugir' da ordem legal.

\section{Modos tradicionais de consumo de bebidas alcoólicas na etnia Pankararu}

D. Severina relata sobre as condições de penúria da infância. Na sua memória existem lembranças de que naquele tempo, somente "tinha roça do travessão [regionalismo: 'cerca que separa a pastagem da lavoura'] para dentro. Quando era no verão, acabava aquelas coisinhas assim plantadas e a gente ficava na fome. Depois chegou o posto e foi que aumentaram mais para fora".

Fala do pai com saudades. Fazia parte do que os Pankararu chamam de 'tronco velho', ao contrário dos mais jovens, que fazem parte das 'pontas de rama'. João Moreno, o capitão da aldeia - índio com a função de organizar a disciplina e que era reputado como a maior liderança 'naqueles tempos' - tinha apreço pelo genitor de d. Severina, considerando-o como seu principal conselheiro. O pai era exímio caçador. Já saía de casa sabendo onde a caça estava. Coisas de "caboclo experiente". Ele também era "doutor de raiz e fazia remédio para vários tipos de doença".

D. Severina, mesmo sendo católica praticante, dança o Toré e assiste aos rituais dos praiás, alegando ser por divertimento e não por uma questão de crença. Para a sua formação religiosa contribuiu a fé paterna e toda uma geração que desde a "bisavó e a tataravó já rezavam na igreja daqui".

Ela também relata que na época de Antônio Conselheiro - certamente no ocaso do século XIX -, houve uma repartição dos lotes entre as várias famílias que ocupavam a área entre as serras do Sorongo e da Fonte Grande. As informações são esparsas, por conta da ausência de documentos. Na memória da informante, está registrada uma carta da princesa Isabel supostamente em posse do velho José Quirino, na qual estavam expostos os critérios de distribuição. Da carta, entretanto, ninguém conhece o paradeiro.

Algumas cenas continuam presentes na sua lembrança, como a de famílias, geralmente extensas e sob a égide do poder paterno. Entre as cenas, narra sobre mulheres e crianças com potes de barro na cabeça, indo buscar água nas fontes naturais. Os homens trabalhavam no roçado e, à noite, ficavam todos sob a luz bruxuleante dos candeeiros.

A instalação do posto indígena engendrou esperanças para muitos, entre eles as famílias que plantavam cana-de-açúcar ou eram proprietárias de pequenos engenhos. Existem referências vagas a essa forma de agricultura e a práticas extrativistas, principalmente de madeira, desde o começo do século XX. Porém destaca-se, no cenário, o roçado de subsistência. 
Na década de 1940, ainda segundo d. Severina, existiam mais de nove engenhos nas proximidades da área pankararu. Evidentemente, além do mel, da rapadura e do açúcar, também havia os produtos da destilação do álcool. Entre eles, uma aguardente produzida nos engenhos vizinhos, "daquelas garrafas tampadas com cortiça: a cachaça peba". Cumpre salientar que o adjetivo 'peba', como regionalismo nordestino, significa algo reles ou ordinário, expressando no imaginário da idosa que o industrializado significa algo de melhor qualidade.

Não existia cerveja, havia vinho Jurubeba e refrigerantes, chamados naquele tempo de 'gasosa'. A compra das bebidas realizava-se fora da área indígena, nas cidades próximas de Tacaratu e Petrolândia Velha - esta submersa pelas águas da represa da hidrelétrica de Itaparica em 1988.

Bebia-se de modo diferente na infância de d. Severina:

Se comprasse dois litros lá, trazia um para aqui, num dia de sábado e domingo. A gente bebia na semana, mas não via ninguém bebendo. Só se morresse gente. Mas não era todo mundo que bebia. Senhor pensa que os rapazinhos daquela época tomavam cachaça? Mas agora até as crianças tomam! Tem menino de 10, de 12, tomando.

Quando se bebia dentro da área indígena, geralmente era de modo discreto, no espaço privado das casas, nas visitas ou festas em finais de semana, ou então, em acontecimentos como festas de batizado ou velórios. Em outras palavras, havia regras tácitas, não ditas mas incorporadas ao cotidiano, que recomendavam o consumo de bebida alcólica principalmente a indivíduos do sexo masculino e de idade adulta. Regras essas que não são cumpridas atualmente.

Naquele tempo, não havia uma legislação específica para as bebidas alcoólicas, porém nos casos de embriaguez que causavam 'tumultos' na comunidade, as regras eram aplicadas de modo punitivo. Era um poder de julgamento e de sentença que se encontrava centralizado no chefe do posto e alimentado por uma visão comunitária de que "tudo que o chefe fazia era certo, por isso que eles não procuravam fazer nada, não questionavam".

Entre os executores dessas ordens disciplinadoras, com um poder de mando, porém hierarquicamente menor que o do referido chefe, encontrava-se a recorrente personagem do capitão João Moreno. Para isso funcionava o dispositivo do encarceramento dos caboclos em um porão que se encontrava sob as instalações do posto. Entre eles, principalmente alguns "bêbados encrenqueiros". D. Severina continua:

Tinha um tal de um porão, debaixo do chão, bem fundo, bem escuro, bem assustador. Buraco feito de tijolo, uma casa feita no chão, embaixo do chão. Acho que tinha uma escadinha para descer e uma portinha. Só cabia 
a pessoa mesmo para entrar. Não tinha como entrar um ar, de cimento. Eu lembro que a gente ia pra escola e eu via, ficava com medo danado de chegar perto [risos].

Portanto, os transtornos provocados pelos efeitos da embriaguez alcoólica recebiam o tratamento de desordem pública, resumido sob a forma de castigo. A imagem era de um espaço subterrâneo, escuro, asfixiante e assustador, propiciando medo às crianças que passavam por perto.

Outro sentimento, o de esperança, surgiu com a instalação do posto indígena do antigo SNI, motivado, entre outros fatores, pelo incentivo à agricultura. Entretanto, esse fato não foi suficiente para conter o processo migratório que já acontecia principalmente entre os homens, através de viagens de idas e vindas, desde a década anterior, anos 1930.

\section{O processo de alcoolização e as viagens de idas e vindas}

Muitos varões iam de trem até Aracaju ou Salvador, embarcando em navios com destino para o Sudeste. Mais frequentes eram os 'paus de arara', em viagens de um a um mês e meio. Habitualmente encontravam trabalho no 'corte de machado' ou na construção civil. D. Severina prossegue:

Eles iam e voltavam. Os que foram voltaram, mas teve gente que de 46 até 50 e tanto, nunca mais voltou. Esse pessoal mais velho. Em 48, com [a hidrelétrica de] Paulo Afonso aumentou esse pessoal que vive mais lá. Vão e voltam, vão e voltam. Tem gente também dessa idade que foi desse tempo de Paulo Afonso e não voltou mais não. Foi carro daqui, caminhão para São Paulo. Teve gente até que já morreu. Sempre foi assim. Naquele tempo chovia no inverno, mas quando era de outubro em diante, era aquela seca.

Arruti (1999) comenta que a existência dos Pankararu da favela Real Parque Morumbi, em São Paulo, um contingente aproximado de 1.500 indivíduos, tem origem nesse fluxo de migração desde a década de 40. Na maioria dos casos, trabalharam nas equipes de desmatamento da companhia de luz do estado de São Paulo e na construção civil. Sem se integrarem à cidade, voltavam sempre que as demandas imediatas fossem atendidas ou quando houvesse prenúncios de um bom inverno.

Outro fragmento narrativo foi um resumo autobiográfico de Cícero, um índio Pankararu, em torno dos 40 anos de idade, experienciador desse processo migratório. Ele se encontrava embriagado na porta de uma pequena mercearia. Antes, tinha pedido uns "trocados para tomar uma e cortar a ressaca". Contou a seguinte história: 
Eu não bebia. Tive um filho e fui trabalhar em São Paulo, em Guarulhos, na construção civil. A gente ganhava dinheiro, mas era escravo. Acordava à meia-noite, trabalhava até às 17 horas. Tudo tem que ser rápido. Quis voltar. Tinha dinheiro até pra comprar um terreno. Hoje está valorizado [suspira]. Era uma vontade de voltar, de voltar. Achei tudo parado. Passei a usar roupa rasgada. Roupa e sapato, aqui é caro. Voltei pra São Paulo. Aí foi meu pai que quis voltar. Danou-se! Depois me disseram que ele tinha morrido. Meu pai morreu, não acredito! Voltei e depois retornei a São Paulo, para ajudar minha mãe. Depois me disseram que ela estava doente. E agora? Fico para ajudar, mas se não for não ajudo. Depois de quatro anos voltei, e não volto mais. Lá você está num bar, e aí chegam quatro: - 'Como é? Vai pagar uma ou não vai?' Gente perigosa!

Ao se pensar em uma organização narrativa, Thorndyke (1975) aponta a articulação dos seguintes elementos: o cenário, o tema, a intriga e a resolução. $\mathrm{O}$ cenário é constituído pelos personagens, pelo espaço e pelo tempo; o tema, pelo objetivo do herói e pelo evento; a intriga, pelo ponto de tensão e pelo desenrolar; por fim, a resolução é caracterizada como o resultado da intriga.

No episódio em foco, o cenário se caracteriza pelo espaço de pobreza da área indígena, emblematicamente expressa no uso de "roupas rasgadas" por Cícero em um tempo subjetivamente lento, em comparação a "tudo tem que ser rápido", como no tempo de São Paulo. Os personagens são Cícero, o narrador e ao mesmo tempo personagem principal, além do pai, da mãe e do filho recém-nascido.

O tema se pauta pela necessidade que o personagem principal tem de sustentar o 'bruguelo' (regionalismo nordestino: recém-nato). Para isso, foi para São Paulo, onde trabalhava na construção civil, tendo vivenciado três viagens de ida e volta.

A intriga na narrativa de Cícero se constitui em três polos de tensão. O primeiro, viver em uma situação de penúria na área indígena, onde dispõe de muito tempo livre, precisando viajar para São Paulo. Lá conseguiu um trabalho cuja remuneração lhe propiciou recursos para poder comprar um terreno - vendido posteriormente - que hoje se encontra valorizado. Entretanto, avalia o trabalho em São Paulo como escravo, haja vista acordar à meia-noite e trabalhar até às 17 horas em Guarulhos. O segundo polo de tensão se desenvolve entre essa mesma necessidade de ter dinheiro para o sustento do filho e a solidão causada pela viagem do pai de volta à área indígena, pela morte desse pai, pela doença da mãe, e pelo conflito entre ficar para ajudá-la pouco e de perto, ou ir embora para poder ajudála mais e de longe. Por último, a experiência de lazer necessária em situações tensas de vida em bares da periferia onde precisava conviver com pessoas consideradas 'perigosas'. 
A migração poderia representar uma estratégia para 'fugir' do desamparo econômico, entretanto essa 'fuga' não preveniu o desamparo existencial. Uma angústia decorrente daquela condenação pela liberdade de escolha: "Ficar para ajudar, mas se não for não ajuda". Sartre (1973:14) afirmava:

Não se pode deixar de ter, na decisão que tomar, uma certa angústia. Tal angústia todos os chefes a conhecem. Mas isso não os impede de agir: pelo contrário, isso mesmo é a condição da sua ação. Isso implica, com efeito, que eles encaram uma pluralidade de possibilidades; e quando escolhem uma, dãose conta de que ela só tem valor por ter sido escolhida.

Contudo, o valor da decisão se mostra ambíguo, pois existe um antagonismo não resolvido entre a 'pobreza afetiva' da metrópole e a 'pobreza material' da área indígena, ressentida de políticas sociais ao final do século XX. Curiosamente, o fim se encontra no começo, ou seja, a resolução apareceu no início da narrativa, deixando implicado que, por conta desses polos de tensão, começou a beber, o que se mostrou de modo dramático.

Pode ser afirmado que se instalou um processo de alcoolismo como doença. Trata-se de um conceito elaborado e aprimorado desde o século XIX. Entre os anos 1960 e 1970, nos Estados Unidos, Elvin Morton Jellinek (1890-1963), da Stanford University, definiu as espécies de alcoolismo como dois tipos de incapacidade: de parar a ingesta depois de iniciada ou de ficar abstinente (Jellinek, 1960).

Para os critérios da Organização Mundial da Saúde (OMS) permanece oficializado o conceito de Griffith Edwards, professor do United Kingdom National Addiction Center, de Síndrome de Dependência Alcoólica, considerada uma única síndrome, presente na nona e décima versão, respectivamente de 1978 e 1992, da Classificação Internacional das Doenças (OMS, 1993).

Em relação ao problema, medidas repressivas mostram-se menos eficazes quando não acompanhadas de medidas preventivas. Entretanto, para o Estado brasileiro, no caso das populações indígenas, não existia uma concepção de que o contexto estressógeno do ambiente sociocultural, junto a determinadas possibilidades intrapsíquicas ou mesmo genéticas, pudessem propiciar o risco para o desenvolvimento do alcoolismo como doença. Ao contrário, havia concepções jurídico-policiais fundamentadas em um controle moral associadas a instrumentos punitivos, ilustrado na década de 1970 pela lei federal n. 6.001/73, já referida anteriormente, identificando crimes contra os índios e a sua cultura o que envolvia a aquisição, o uso e a disseminação de bebidas alcoólicas, nos grupos tribais ou entre índios não integrados (Brasil, 1983).

A condição de campesinato indígena faz a etnia Pankararu não ser reconhecida por alguns grupos de brancos que têm interesses nas terras, sendo atribuída por esses grupos, de modo pejorativo, a qualidade de etnia misturada. 
Entretanto, na perspectiva de uma leitura crítica da ciência social, essa etnia é considerada como emergente.

Nessa dupla condição, cidadão e indígena, uma contradição não pode deixar de ser percebida. Alguns índios exercem funções públicas nos municípios vizinhos, como funcionários de secretarias municipais, ou mesmo por meio de mandatos como vereadores. Outros sujeitos são comerciantes, professores, educadores, trabalhadores da construção civil, agricultores, portanto participantes ou integrados à vida social brasileira.

Entretanto, esses sujeitos estão proibidos por lei de comercializar e consumir bebidas alcoólicas na área indígena. Diante da ambiguidade da norma legal que prescreve como ilícita uma condição legítima de consumo, surge como alternativa fugir da própria lei. Entre outras razões, existem necessidades materiais que engendram estratégias transgressoras de sobrevivência. O comércio clandestino será discutido no próximo tópico.

\section{Fugir da lei: o comércio clandestino de bebidas alcoólicas}

A etimologia do substantivo 'lucro' é a forma latina lucru, que pode ser traduzida como vantagem ou logro (Nascentes, 1955). Esse conceito estava ausente dos rituais nativos de produção e consumo de etílicos, pois eram valorizados principalmente os 'valores de uso', no sentido de propriedades materialmente inerentes aos produtos resultantes de um trabalho artesanal (Marx, 1968). Entre esses usos, os efeitos da embriaguez provocados pelas bebidas alcoólicas e também os efeitos anestésicos, afrodisíacos, energéticos, nutritivos, terapêuticos ou narcóticos (Heath, 1974).

As bebidas progressivamente passaram a ter determinados 'valores de troca', em um sentido mais quantitativo do que qualitativo, a partir de um cálculo que aferia o tempo de trabalho socialmente necessário para a produção de uma mercadoria (Marx, 1968).

O período colonial foi determinante para que os países dependentes do sistema monetário ocidental fossem atingidos pela abertura e fortalecimento do mercado moderno em um nível mundial, o que afetou quase todos os sistemas econômicos ditos primitivos ou camponeses. Em outras palavras, o chamado processo de globalização, caracterizado como um efeito tardio da modernidade, implicou a construção de sociedades plurívocas, por serem permeadas de várias possibilidades de interpretação das leis constituídas, destacando-se mais os recursos argumentativos do que a própria concepção de justiça social (Godoy, 2003).

Em sociedades como essas, complexas e multifacetadas, introduziu-se de forma acentuada uma pressão ao consumo. Isso redundou em um desenvolvimento tecnológico, em um sentido receptivo, engendrando mais 
desigualdades sociais e fazendo os sujeitos sentirem-se desprovidos de autonomia e dignidade.

Esse processo de troca é o que Weber (1992) define como uma ação social, e que, de uma perspectiva econômica, envolve a produção, a distribuição e o consumo de mercadorias, processo regulamentado por um plano racional, encontrando-se vínculo com algum tipo de exercício de poder. Em outras palavras, o 'valor de troca' das bebidas alcoólicas entre os povos indígenas no Nordeste também se caracteriza como uma ação social, alternativa ao modelo campesino de subsistência, e apresenta uma determinada racionalidade que se configura como uma atividade de exploração econômica.

Essa lógica está consubstanciada na narrativa de um pequeno comerciante pankararu, de 42 anos, chamado Benedito:

Quando o pessoal confiou [regionalismo nordestino: confirmou] que a cachaça podia dar lucro, apesar das dificuldades, das derrotas [regionalismo: agravos] que ela traz - aumenta briga, aumenta criminalidade -, todo mundo passou a vender. Mas só que era escondida. Recentemente, agora, nas festividades do nosso padroeiro [novenas de Santo Antônio], o uso de bebida alcoólica - tanto do famoso 51 - a pessoa via dos barracos, nas mesas, para todo mundo ver. Antigamente, vinha uma polícia e prendia, as bebidas e tudo (...). Esse ano não, era praticamente livre, como se fosse liberado, como se ninguém mais agisse contra.

A ausência de empregos, os baixos preços da produção agrícola, a diminuição de verbas federais (com exceção do programa emergencial de combate à seca) fazem dessa transação uma estratégia transgressora de renda. Entretanto, mesmo com a ação da Polícia Federal na área, em abril de 2000, dois meses antes da novena de Santo Antônio, realizada em junho do mesmo ano, as vendas aconteciam de maneira aberta.

Ao redor da igreja do padroeiro, foram montadas várias barraquinhas onde eram ofertados pratos de comida e litros de bebidas alcoólicas. As garrafas ficavam em pequenas mesas ao lado dos rústicos balcões de madeira.

Segundo o mesmo comerciante, a quantidade vendida dependia da concorrência.

Aquilo ali é só uma amostra para a pessoa vender. Os donos, os barraqueiros, os barraqueirinhos são tão fracos que eles não conseguem comprar assim duas, três caixas para colocar estoque. Mas se eles colocam uma caixa de 51 ou de uma bebida com doze litros, eles chegam a vender uma caixa facilmente. Mas digamos que tem muita cachaça dentro da área, então praticamente a pessoa encontrando dois reais, ele apura, ganha 
cinquenta centavos de lucro. Ele ganhando, a tendência é quanto mais difícil a pessoa encontrar a cachaça, vamos supor que outros não tenham, o que acontece? Ele diz: - 'Rapaz, eu tenho aqui, só que é dois litros, só tem um litrinho mesmo, só vou vender por tanto'. A pessoa está doida para beber, então ele vende até por três, por quatro reais. $O$ importante é que mate aquele desejo. Tanto vende é que já tem gente usuário da cachaça que carrega [regionalismo nordestino: furta] até a própria comida de dentro de casa para trocar por cachaça. Eu tenho um vizinho aqui, ao lado da minha casa, que ele de tanto beber começou a ver a própria polícia querendo pegar ele. Corria, se escondia, dizendo que alguém queria matar, vendo coisa ao lado dele.

Existe uma regra liberal do mercado que determina o valor da mercadoria pela relação entre a oferta e a procura. Pode-se visualizar a dimensão dessa demanda quando está presente o sintoma da 'fissura'. Traduzido do inglês craving, definese como um fenômeno central na clínica da dependência química, calcado em um desejo intenso e incontrolável de consumo e cujas explicações etiológicas são controversas.

Marques e Seibel (2000) discutem entre os modelos de causalidade, o comportamental, em que a manutenção do uso da substância se daria a partir da expectativa do seu efeito prazeroso, previamente aprendido. Entre esses prazeres, possivelmente 'fugir' do sofrimento produzido pelas agruras ambientais ou pelo próprio sintoma de abstinência.

O conhecimento dos pontos de venda clandestina de bebidas alcoólicas na área pankararu está presente na narrativa de Mateus, um adolescente de apenas 17 anos. Ele descreve:

Em Itaparica [vila da Companhia Hidrelétrica do São Francisco, localizada no município de Jatobál tem um armário que vai daqui até acolá, no barracão, é tudo bebida. Em Petrolândia, tem outro, está cheio de comprador. Está vendo aquela casinha, lá? Está cheio de tambor com vinte caixas dentro. Não passa um mês, essas vinte caixas. Todo dia, tem um que bebe, secou [regionalismo: esvaziou] um litro e meio.

Esses compradores, em Itaparica e Petrolândia, trazem as garrafas para dentro de Brejo dos Padres, escondendo-as dentro de tambores cilíndricos, usados para o armazenamento de uma quantidade de garrafas a serem utilizadas no comércio. Em outras situações, para o consumo pessoal, foram relatadas garrafas escondidas atrás de caixa acústica de aparelho sonoro, dentro de guarda-roupa, geralmente em lugares inusuais. 
Em termos contábeis, o preço médio de um litro de aguardente no final da década de 1990, girava em torno de dois reais. É uma bebida de baixo custo e de alta gradação alcoólica, em torno de $43 \%$, podendo ser revendida nos seguintes preços: entre as medidas existe a quartinha (150 ml do copo americano e vendida a $\mathrm{R} \$ 0,30$ ) e a meiota (300 $\mathrm{ml}$ equivalente a uma garrafa de refrigerante e vendida a $R \$ 1,00)$. Cada litro possui em torno de sete quartinhas e cerca de três meiotas podendo gerar um lucro de 50 a $100 \%$ por litro.

Finalizando, existe uma experiência de 'logro', o que pode ser remetido a um sentido de 'lesar', ou seja, da instituição de uma determinada moral: o importante é levar vantagem em tudo.

\section{Conclusão}

Pensar no processo de alcoolização dos povos indígenas no Brasil é complexo em função dos heterogêneos perfis dessas populações e dos vários conceitos e critérios atribuídos ao alcoolismo normal ou patológico.

Muitas críticas, ideologicamente construídas por setores conservadores da sociedade nordestina, não reconhecem essas populações como indígenas. Entre os motivos para a oposição existem os direitos da população indígena sobre a terra, reconhecidos pelo Estado, em uma luta historicamente iniciada desde a década de 1940.

Nota-se uma transformação em relação ao padrão de relacionamento da etnia Pankararu com a mais antiga substância psicoativa da humanidade, o álcool etílico, expressa nas três interpretações da expressão metafórica 'tomar uma fuga'.

A primeira, relacionada ao tempo da tradição, calcado na cultura familiar e agrícola, está vinculada ao descanso bucólico em atividades laborativas ou cerimoniais, havendo algumas referências a desordens de comportamento.

A segunda, associada com as transformações do Estado brasileiro desde a Era Vargas, com processos migratórios de idas e vindas, resultando em conflitos de natureza psicossocial que podem ter influência da determinação do alcoolismo como doença.

Nesse contexto social e econômico, os povos indígenas, entre eles os Pankararu de Pernambuco, fazem parte do contingente migratório da força de trabalho presente em viagens de idas e vindas ao Sudeste brasileiro.

Por fim, em consequência da ausência de políticas públicas ao tempo do fim do século XX no Brasil, a população pankararu tem acesso à terra, mas não tem ao 'tempero', vindo o comércio clandestino a mostrar uma racionalidade que o poder público interpreta, primordialmente, de acordo com os sentidos jurídicopoliciais. 
Portanto, uma leitura etnográfica permite, dentro dos limites da sua fotografia, fornecer elementos de análise que possibilitem entender a afirmação de uma índia Pankararu - "Caboclo gosta de beber!" - de modo festivo e não angustiante, construtivo e não desagregador.

\section{Referências}

ACIOLI, M. S. O Processo de Alcoolização entre os Pankararu: um estudo em etnoepidemiologia, 2002. Tese de Doutorado, Campinas: Unicamp, 2002.

ANDRADE, M. C. Economia Pernambucana no Século XVI. Recife: Arquivo Público Estadual, 1962.

ARRUTI, J. M. A. A árvore pankararu: fluxos e metáforas da emergência étnica no sertão do São Francisco. In: OLIVEIRA, J. P. (Org.). A Viagem da Volta: etnicidade, política e reelaboração cultural no Nordeste indígena. Rio de Janeiro: Contracapa, 1999.

BERNARDI, B. Introdução aos Estudos Etnoantropológicos. Lisboa: Edições 70, 1988.

BRASIL. Ministério do Interior/Funai. Legislação/Jurisprudência Indígenas. Brasília: Funai, 1983.

Charaudeau, P. G MAingueneau, D. Dicionário de Análise do Discurso. 2. ed. São Paulo: Contexto, 2006.

FORTES, J. R. A. G CARDO, W. N. Alcoolismo: diagnóstico e tratamento. São Paulo: Sarvier, 1991.

GODOY, A. M. Globalização e direito: a mundialização no capital e seus efeitos no modelo normativo brasileiro. Argumentum: Revista de Direito, (3): 49-79, 2003.

HEATH, D. B. Perspectivas socioculturales del alcohol en América latina. Acta Psiquiátrica y Psicológica de América Latina (20): 99-111,1974.

HOUAISS, A. G VILLAR, M. S. Dicionário Houaiss da Língua Portuguesa. Rio de Janeiro: Objetiva, 2001.

JELLINEK, E. M. The Disease Concept of Alcoholism. New Haven: College and University Press, 1960.

LÉVI-STRAUSS, C. Introdução à obra de Marcel Mauss. In: MAUSS, M. Sociologia e Antropologia. 11. ed. São Paulo: EPU, 1974.

LÉRY, J. Viagem à Terra do Brasil. 4. ed. São Paulo: Martins, 1967.

MARQUES, A. C. G SEIBEL, A. C. O craving. In: SEIBEL, S. D. G TOSCANO JR., A. (Eds.). Dependências de Drogas. São Paulo: Atheneu, 2000.

MARX, K. O Capital: crítica da economia política. v I. Rio de Janeiro: Civilização Brasileira, 1968.

MENÉNDEZ, E. Socioantropología del proceso de alcoholización en América Latina, 19701980 (primeira parte). Acta Psiquiátrica y Psicológica de América Latina (29): 247256, 1983. 
NASCENTES, A. Dicionário Etimológico da Língua Portuguesa. Rio de Janeiro: Francisco Alves, 1955.

OLIVEIRA, J. P. A viagem de volta: reelaboração cultural e horizonte político dos povos indígenas no nordeste. In: OLIVEIRA, J. P. (Org.). Atlas das Terras Indígenas do Nordeste. Rio de Janeiro: Peti/Museu Nacional/PPGAS/UFRJ, 1994.

OLIVEIRA, R. C. Identidade, Etnia e Estrutura Social. São Paulo: Pioneira, 1976.

OLIVEIRA, R. C. Mauss. São Paulo: Ática, 1979. (Coleção Grandes Cientistas Sociais)

OLIVEIRA, R. P. A manhã é uma esponja: um estudo sobre a engenhosidade semântica. Delta, 13(2): 247-273, 1997.

ORGANIZAÇÃO MUNDIAL DA SAÚDE (OMS). Classificação de Transtornos Mentais e de Comportamento da Cid 10. Porto Alegre: Artes Médicas, 1993.

ORLANDI, E. R. Análise de Discurso: princípios e procedimentos. 7. ed. Campinas: Pontes, 2007.

PERNAMBUCO. Base de Dados do Estado (BDE). Recife: Governo de Pernambuco, 2007. Disponível em: <www.bde.pe.gov.br/visualizacao/Visualizacao_formato2.aspx? CodInformacao $=8416 \operatorname{Cod}=3>$. Acesso em: 13 jan. 2011.

PROJETO ESTUDOS SOBRE TERRAS INDÍGENAS NO BRASIL (PETI). Museu Nacional. Atlas das Terras Indígenas do Nordeste. Rio de Janeiro: PPGAS/Museu Nacional/ UFRJ, 1993.

RIBEIRO, D. Prefácio. In: GOMES, M. P. Os Índios e o Brasil. Petrópolis: Vozes, 1991.

RIBEIRO, D. Os Índios e a Civilização: a integração das populações indígenas no Brasil moderno. São Paulo: Companhia das Letras, 1996.

SARTRE, J. P. O Existencialismo é um Humanismo. São Paulo: Abril Cultural, 1973. (Coleção Os Pensadores, v. XLV)

STADEN, H. A Verdadeira História dos Selvagens, Nus e Ferozes Devoradores de Homens, Encontrados no Novo Mundo, a América. Rio de Janeiro: Dantes, 1999.

THORNDYKE, P. Cognitive Structures in Human Story Comprehension and Memory, 1975. Tese de Doutorado, Stanford: Departament of Psychology, Stanford University.

WEBER, M. Economía y Sociedad. México: Fondo de Cultura Económica, 1992. 


\section{Os Índios Maxakali: a propósito do consumo de bebidas de alto teor alcoólico ${ }^{1}$}

João Luiz Pena

O aparecimento das bebidas de alto teor alcoólico ${ }^{2}$ nas sociedades indígenas é contemporâneo à colonização e é, sem dúvida, fruto do contato com o 'mundo dos brancos'. Simonian (1996) sustenta que essas bebidas alcoólicas foram difundidas pelos brancos entre os indígenas como uma estratégia deletéria que tinha como objetivo a liberação das terras indígenas para a colonização europeia. Sem perder de vista esta hipótese, procura-se neste capítulo levantar uma outra segundo a qual deve ser considerada a possibilidade de os povos indígenas terem se apropriado ativamente dessas bebidas alcoólicas e, consequentemente, exercido algum tipo de controle simbólico sobre elas. Assim, a partir de uma revisão bibliográfica, o povo Maxakali é destacado, levando-se em consideração tais hipóteses. A ênfase do estudo recai no contexto em que se insere a população indígena selecionada. Esse contexto é formado pela trama das relações interétnicas que está intrinsecamente conectada com o tipo de exploração e de devastação de que tal grupo foi e é vítima, bem como com o modo que esses aspectos são articulados dentro da lógica indígena.

\section{Os Maxakali}

Os índios Maxakali ${ }^{3}$ e outros grupos - como os Giporok, Makoni, Malali, Monoxó, Naknenuk, Pajixá e Pataxó - que mantinham uma intensa interação por meio de alianças e guerras intertribais, ocuparam os vales dos rios Jequitinhonha, Mucuri, do Prado, Itanhém, São Mateus e Doce, em Minas Gerais, Bahia e Espírito Santo. Dentre os grupos citados, apenas os Maxakali escaparam ao extermínio e absorção de sua cultura pela sociedade envolvente (Álvares, 1992). Os Maxakali, na verdade o que provém e resta da junção de diversos grupos de várias regiões, vivem, atualmente, em quatro terras indígenas no nordeste de Minas Gerais, nos municípios de Bertópolis, Ladainha, Santa Helena de Minas e Teófilo Otoni. Até 2004, os Maxakali estavam estabelecidos em duas glebas, hoje contíguas, a de Água Boa (Santa Helena de Minas) e a do Pradinho (Bertópolis). De acordo com 
Rubinger (1980), tais designações foram tomadas dos riachos que as atravessam. Quanto à classificação linguística dos Maxakali, segundo Álvares (1992), Aryon Dall'Igna Rodrigues incorpora-os ao tronco macro-jê, introduzindo-os na família linguística maxakali, juntamente com os Capoxó, Makoni, Malali, Monoxó, Pataxó. À exceção dos Maxakali e Pataxó, os demais grupos estão extintos desde meados do século XIX. Em 2008, os Maxakali contavam com uma população de 1.491 indivíduos, segundo dados do censo populacional conduzido pela Universidade Federal de Ouro Preto. ${ }^{4}$ Desse total, 740 eram homens e 751 mulheres. É importante ressaltar que nesse período quase $68 \%$ da população maxakali tinha até 19 anos de idade.

\section{Os Maxakali e as bebidas de alto teor alcoólico}

Relatos do século XIX (Maximiliano, 1989; Pohl, 1976; Saint-Hilaire, 1975) deixam transparecer que os Maxakali sofreram um processo de descaracterização ou pelo menos vinham, aparentemente, adaptando-se ao modo de vida caboclo. No entanto, nenhum deles menciona peremptoriamente que tais indígenas faziam uso de bebidas de alto teor alcoólico. Maximiliano (1989) observa, em poucas palavras, que os Maxakali que habitavam as matas do Jucurucu utilizavam o cauim. ${ }^{5}$

A relação do povo Maxakali com as bebidas de alto teor alcoólico foi relatada pela primeira vez por Nimuendajú (1958), em 1939. Vizinhos dos índios iam à aldeia levando "lata de querosene de cachaça" com o objetivo de embriagálos e posteriormente praticar sevícias contra as mulheres.

Apontando uma data que precede a colocada em destaque por Nimuendajú (1958), Soares nos informa que um dos integrantes da equipe que realizou nas cercanias, a partir de 1918, o traçado de uma estrada, após terminar o levantamento topográfico na região, permaneceu no local e os Maxakali "ajudaram-no a plantar cana e instalar um pequeno alambique no qual se fabricou a cachaça" (Soares, 1998: 5). A autora menciona que a cachaça permitiu uma euforia ainda mais elevada do que as bebidas fermentadas, colocando-os em contato com os yãmiy. ${ }^{6}$ Além disso, apoiada nas considerações de um informante, assinala que "nos estados de transe provocados pela bebida [destilada], os Maxakali ressuscitavam antigas divergências e se matavam" (Soares, 1998: 5).

Todavia, isso não quer dizer que este povo não tenha tido acesso à aguardente numa época anterior. Era praxe, tanto dos colonizadores como dos viajantes estrangeiros, oferecerem aguardente aos índios, principalmente, como um meio de seduzi-los a desempenhar algum tipo de atividade que lhes interessava. Desse modo, acredita-se que é factível especular que os Maxakali, ao longo de 
suas interações com os não índios, também tenham experimentado essa bebida destilada.

Uma vez que os Maxakali optaram, enquanto foi possível, por manter certo distanciamento da sociedade colonizadora em expansão, provavelmente, também se viram obrigados a ter acesso de forma intermitente aos produtos dos não índios, incluindo-se aí a aguardente. A imagem dos Maxakali construída pelos relatos é a de um povo que ora se aproxima, ora se afasta, pede proteção aos colonizadores, depois se desloca novamente para as matas.

É somente a partir da segunda metade do século XX que os dados sobre o contato entre os remanescentes dos Maxakali e a população regional são bem mais detalhados. No início da década de 1960, Rubinger (1962-63) destaca alguns fatos que deixam transparecer que o uso da bebida de alto teor alcoólico vai se tornando comum entre os Maxakali. Em seu diário de campo, o etnólogo salienta que, aos sábados e domingos, os índios buscavam os povoados vizinhos onde procuravam comprar cachaça às escondidas. Mais adiante, afirma:

nos dias de feira, é imensa a quantidade de pessoas bêbadas. A cachaça é fundamental na vida dos neobrasileiros e já significa muito também, na vida dos índios. (...) Nas casas comerciais de Batinga é muito comum ver-se os molhos de flechas e arcos que são comprados aos índios por um preço irrisório ou trocados por cachaça. (Rubinger, 1962-63: 169-170, grifo do autor)

Ao longo de suas anotações, o etnólogo insiste em denunciar a venda ou a troca ilegal de cachaça praticada pelos comerciantes da região. Esse fato demonstra a fragilidade da política voltada para a proibição de venda de bebidas alcoólicas pela população envolvente para os índios, ${ }^{7}$ que esbarra na dificuldade de fiscalização e na impunidade dos infratores, quando denunciados. Por mais de um momento, Rubinger (1962-63: 70) frisa que, quando os Maxakali bebem, "brigam entre si, uns quebrando as cabeças dos outros". Destaca ainda que "o maior inimigo dos Maxakali é a cachaça" e afirma que "quase todos bebem, mas o pagé (sic) é uma das exceções da regra, apesar de sua mulher, Jé Gdoiketut, gostar tanto de cachaça que recentemente queimou a perna e só 24 horas depois ficou sabendo". A fim de ilustrar os conflitos gerados pela cachaça, Rubinger descreve as seguintes cenas:

Acaba de chegar aqui o índio Joaquim, irmão de Firmino. Está bêbado, com um porrete na mão e gesticula chamando os índios de Água Boa para bater nos do Pradinho. (...) Adolfo acaba de chegar. Também está alcoolizado como Joaquim. Chamou-me em um canto para dizer que o antigo inspetor Fernando Cruz era bom e que os índios faziam festa no pátio do posto para ele e que os índios têm dele muitas saudades. 
Joaquim que havia desaparecido por alguns minutos retornou mais bêbado ainda e, com um porrete, atacou sua própria mãe (Joaná) atingindo-a na espinha. Em seguida, arremeteu contra vários índios novos, atingindo um deles. Nesta altura, diversos índios (mulheres) se atracaram valentemente com ele procurando tomarlhe a arma, tendo Joaquim atingido a várias delas. Cenas como esta são muito comuns na Aldeia do Pradinho. (Rubinger, 1962-63: 255-257)

Alguns conflitos, conforme o relato de Rubinger, chegavam até mesmo a terminar em assassinato:

A índia Santinha que eu conheci em julho foi morta em outubro de 1962. O índio Modesto, filho de Mikael, comprou 6 litros de cachaça no Baio (perto do Pradinho). Deu Santinha para beber, levou-a para o mato e praticou o ato sexual. Em seguida, furou-a com a faca segundo tudo indica. (...) Os parentes encontraram-na muito mal. Santinha veio a falecer na Aldeia. (...) a família do criminoso mudou para o alto do morro onde morava Luizinho antes de ser assassinado. Logo que Santinha morreu, seu filho pôs fogo na casa de Modesto. (Rubinger, 1962-63: 174-175)

Fato como o descrito também é narrado por Popovich (1994: 21):

Quando Luizinho Mariano espancou sua esposa, Mariazinha, na estrada até a morte, ambos estavam bêbados. O corpo dela, enrolado numa esteira, foi levado para casa pelos filhos. A família foi convocada para lamentar a trágica morte. (...) Assim que o marido percebeu o que havia feito, e as consequências que poderiam advir do seu ato, fugiu para a casa de sua irmã, Maria. Exatamente um mês mais tarde, ele foi morto a pancadas enquanto dormia na casa de sua irmã. O castigo compensou o crime e 'estava pago'. Os Maxakali exercem justiça através da morte recíproca.

Pena e Las Casas (2004: 1- 2), por sua vez, relatam que:

No dia 02 de maio de 2004, domingo, dia de feira neste município, após o retorno de um grupo de indígenas de Santa Helena de Minas até a localidade de Água Boa, após consumirem bebidas de alto teor alcoólico, Alfredo Maxakali, um senhor de 77 anos, residente na aldeia do Bueno, foi assassinado com pauladas na cabeça. Três crianças Maxakali viram a agressão acontecendo e relataram os fatos a seus parentes. Um jovem do grupo da Noêmia Maxakali, chamado José Carlos Maxakali, foi acusado de ter assassinado este senhor. $\mathrm{O}$ exame de corpo delito confirma a suspeita de assassinato do Alfredo, sendo diagnosticada como causa mortis (Classificação Estatística Internacional de Doenças e Problemas Relacionados à Saúde $10^{\mathrm{a}}$ Revisão - CID-10): traumatismo craniano encefálico, com afundamento da região orbital. 
Na segunda-feira, dia 03 de maio, parte do grupo de parentes e aliados da família do Alfredo estava na cidade de Santa Helena de Minas com o objetivo de receber o seu corpo que havia sido levado para o IML de Teófilo Otoni. Alguns dos parentes do falecido que esperavam o corpo no Polo Base de Santa Helena de Minas estavam consumindo bebida alcoólica e provavelmente devem ter levado tal produto para a Terra Indígena. De acordo com alguns relatos, no momento em que o caminhão chegou na Terra Indígena levando o corpo para ser enterrado, diversos homens estavam armados e foram buscar vingança antes mesmo de enterrar Alfredo. De fato, um processo de vingança foi estabelecido, que culminou com os assassinatos de Jupi Maxakali e Valtair Maxakali, sendo que Badu Maxakali ficou ferido neste evento.

Rubinger ressalta que, na época em que visitou os Maxakali, o inspetor do posto, Tubal Fialho Vianna, era um inveterado consumidor de cachaça e este hábito era utilizado pelos índios como argumento para que também pudessem beber. Tornou-se corriqueiro, quando admoestado, o índio dizer: "Você [Tubal] bebe, eu também posso beber" (Rubinger, 1962-63: 85). A existência do pedido de construção de um alambique na área indígena, feita pelo capitão do Pradinho a Rubinger, bem como a informação de que o encarregado do posto, Fernando Cruz (anterior a Tubal), distribuía cachaça aos índios, evidencia que, nessa época, a cachaça já estava disseminada entre os Maxakali.

Vale ressaltar que, em seu diário de campo, Rubinger não procura problematizar os motivos que levam os índios Maxakali a consumirem bebidas de alto teor alcoólico. No entanto, suas descrições apontam para um contexto positivista, cumprindo uma função eminentemente conservadora, pois, ao apresentar uma visão fragmentada da vida social dos Maxakali, segundo a qual os indígenas estariam se tornando dependentes por causa da ação dos não índios (que facilitariam o acesso deles às bebidas alcoólicas), mascaram suas contradições, que poderiam revelar a convergência e manipulação de seus universos tradicional e moderno, num processo de ordem e desordem, de constante reconstrução de sua sociabilidade e seu modo de ser.

De 1967 a 1973, a Terra Indígena Maxakali esteve sob intervenção militar, onde uma corporação composta por índios - a Guarda Rural Indígena (Grin) - foi formada para, entre outros objetivos, "impedir a venda, o tráfego (sic) e o uso de bebidas alcoólicas" (Queiroz, 1999: 71) pelos índios. Segundo Marcato (1980), os conflitos com a população envolvente e o problema do abuso de cachaça na T. I. Maxakali recebeu uma solução de caráter policial. Desse modo, procurou-se limitar os deslocamentos dos índios, que foram compensados com a criação de uma loja e uma mercearia dentro da terra indígena, e a área passou a ser patrulhada pelos soldados da Grin - sete índios Maxakali. A intervenção do Estado, no tocante ao controle do consumo de bebidas de alto teor alcoólico, teve um caráter repressivo 
e punitivo. Tanto é verdade que em 1974, assim que o patrulhamento da região teve o ritmo diminuído, "outra vez se fizeram afoitos os comerciantes de aguardente, vivendo os Maxakali constantemente embriagados" (Marcato, 1980: 157).

No final da década de 90, Oscar Torretta (1997), que teve a oportunidade de trabalhar entre a população Maxakali somente por um período de duas semanas no ano de 1997, sugere que aproximadamente 45\% da população adulta Maxakali (idade superior a 10 anos) ${ }^{8}$ bebe sistematicamente com frequência semanal. Consoante ao seu relato, não existe distinção de sexo no que diz respeito ao acesso às bebidas alcoólicas. Devido ao preço das substâncias alcoólicas e à dificuldade de encontrá-las no mercado, entre os Maxakali prevalece o seguinte consumo em ordem decrescente: uma mistura composta de álcool puro, água e suco em pó, nas proporções de um por um; cachaça ou outras bebidas (conhaque, uísque, vodka) e desodorante. O acesso a estas bebidas para os indivíduos do sexo masculino é mais precoce do que para os indivíduos do sexo feminino. Respectivamente, 10 anos no primeiro caso e por volta de 12 anos no segundo.

Torretta (1997) realizou um ciclo de entrevistas semiabertas e abertas na T. I. Maxakali e evidenciou que aproximadamente $40 \%$ da população adulta de Água Boa e 50\% do Pradinho bebem com frequência semanal. Também observou que $5 \%$ da população adulta, de ambas as glebas, bebe com frequência ainda maior. Além do mais, este autor acrescenta que as bebidas de alto teor alcoólico são procuradas, principalmente, durante os fins de semana e feriados. Igualmente, informa que não há um horário determinado para ter acesso às mesmas nem é necessária a companhia de outras pessoas para consumi-las.

Indubitavelmente, a bibliografia disponível sobre os Maxakali confirma que, nos séculos XX e XXI, alguns indivíduos consumiam bebidas de alto teor alcoólico, principalmente a cachaça, ${ }^{9}$ mas nenhum autor apresentou fatos que pudessem fundamentar o estigma de alcoólatra de que a população Maxakali é alvo. O que foi descrito, como se salientou, é que alguns indivíduos bebem e causam confusão, chegando até mesmo a cometer assassinato em seu transe alcoólico.

\section{Hipóteses sobre a apropriação das bebidas de alto teor alcoólico}

Pretende-se considerar a possibilidade de os Maxakali terem aderido ao uso de bebidas destiladas porque, de algum modo, elas foram apropriadas ao universo cultural deles, e não (só) porque se sentiram pressionados pelo contexto das relações interétnicas com os brancos, como destacam Pereira (1999), Câmara Cascudo (1986) e Ribeiro (s. d).

A teoria de Horton (1965), que preconiza que o consumo de bebidas de alto teor alcoólico está associado à ansiedade, ajuda a pensar a situação vivida 
pelos Maxakali. Tal fato apoia-se em informações contidas nos trabalhos de Soares (1998), Torretta (1997), Silva (1996), Popovich (1994), Álvares (1992) e Nascimento (1984). Assim, buscou-se estudar os Maxakali utilizando como ferramenta analítica o modelo comportamental de Horton (1965), pesquisador que desenvolveu em 1943 o primeiro estudo antropológico específico, propondo uma teoria psicocultural e integrada à rede sociocultural, que se fundamenta na análise comparada e de casos culturais. Em sua análise, realizada com dados dos arquivos do cross-cultural survey do Instituto de Relações Humanas da Universidade de Yale, referentes a 56 sociedades indígenas e de folk, distribuídas em todo o mundo, Horton assevera que a ansiedade é uma reação universal que se desenvolve em determinadas condições da vida social e que precisa ser reduzida para assegurar a continuidade do grupo, sendo o álcool o principal instrumento de redução da ansiedade dos conjuntos sociais. Os maiores índices de ansiedade evidenciados por sua pesquisa são despertados pelas situações aculturativas, quando tal processo envolve danos à economia de subsistência, crença em feitiçaria e impulsos agressivos inibidos.

Para Horton (1965: 411-412),

como a ansiedade é o agente de inibição, a redução da ansiedade tende a reduzir a inibição e libertar respostas anteriormente inibidas. As próprias inibições são o resultado de castigos impostos pela sociedade, segundo a sua tradição cultural, a certas formas prescritas de ação (especialmente os atos sexuais e agressivos).

Diante dessa teoria elaborada por Horton, procurou-se analisar o comportamento maxakali em relação à bebida. Diversos cronistas e etnólogos mostram a grande mobilidade desse povo nos tempos da colonização. Três motivos orientavam seu comportamento: a necessidade do deslocamento em busca de caça e coleta, a expansão das frentes de penetração e a rivalidade existente entre os Maxakali e os Botocudo. Nascimento (1984) afirma que, antes da chegada do colonizador, essa etnia garantia a sobrevivência explorando a fauna e a flora através desses deslocamentos que ocorriam "no interior de um vasto território circunscrito apenas aos limites impostos pelos outros grupos caçadores" (Nascimento, 1984: 58).

Com a ocupação da região que eles habitavam pelas frentes de expansão e com a fixação definitiva destas, os Maxakali viram-se restritos aos limites da terra indígena, tendo seus meios originais de subsistência destruídos. Álvares (1992: 37-38) põe em evidência que os seus territórios de caça e coleta foram "drasticamente reduzidos e praticamente devastados, estas duas atividades se tornaram esporádicas e eventuais, principalmente a caça". 
Álvares (1992: 38) diz que "as caçadas coletivas ${ }^{10}$ possuem um caráter marcadamente ritual. Elas são realizadas, geralmente, no encerramento de cada ciclo cerimonial - yãmiyxop" ${ }^{11}$

Mais adiante, a autora salienta que,

embora a caça seja uma atividade cada vez mais distante do cotidiano Maxakali, seu rendimento simbólico ainda é grande. Toda a vida cerimonial dos Yãmiyxop está centrada na obtenção, distribuição e consumo da carne, assim como sua cosmologia está marcada pelo discurso das relações entre caça e predador. (Álvares, 1992: 39)

Além das caçadas coletivas e daquelas que envolvem alguns poucos homens para abater pequenos animais, "os Maxakali tratam a pescaria masculina como uma forma particular de caçada" (Álvares, 1992: 39). Vale acentuar que tanto Nascimento (1984) quanto Álvares (1992) e Silva (1996) destacam que os Maxakali, como na maioria das vezes não encontram animais de porte para satisfazer suas necessidades de subsistência ou seus rituais, começaram a caçar os bois de seus vizinhos - os fazendeiros.

Em 1997, Torretta chamou a atenção para o fato de os Maxakali conservarem, apesar do sedentarismo imposto pela ocupação das terras contíguas à terra indígena pela sociedade envolvente e pela própria dimensão e devastação de suas terras, uma 'mentalidade' de caçadores. Segundo o autor, os fatores que revelam essa mentalidade estão ligados ao hábito de deslocar suas habitações de acordo com o jogo de alianças; a prática de queimar suas choças após a morte de um dos afins; a distribuição coletiva dos alimentos, sobretudo das cestas básicas distribuídas pela Fundação Nacional do Índio (Funai), e da carne de boi que é repartida ao fim do ciclo cerimonial; assim como a habilidade de caçar, tanto dos homens quanto das crianças. Expõe ainda que alguns dos entrevistados afirmam que caçar está entre as coisas que os deixam mais felizes. Esta assertiva o fez sugerir que o alimento mais nobre na concepção maxakali está associado com a caça.

Além dessas considerações, não podemos perder de vista a cosmologia maxakali. Ela é importante para compreender a visão de mundo que os orienta e que os fazem ter, conforme afirma Torretta (1997), uma 'mentalidade' de caçadores.

Ao longo de suas vidas, os Maxakali precisam possuir cantos e yãmiy para se transformarem em pessoas completas. De acordo com Álvares (1992: 115), "tornar-se pessoa Maxakali é um estado a ser alcançado e não uma posição permanente, dada de uma vez". Os velhos, como já atingiram a maioridade, ensinam os cantos aos jovens. O conhecimento, adquirido com os cantos e a posse dos yãmiy, inicia-se na infância e só se completa com a morte, quando a alma dos vivos (koxuk) transforma-se em canto (yãmiy). Os cantos são os meios pelos quais os Maxakali e os yãmiy se comunicam (Álvares, 1992). 
O conhecimento dos yãmiy - saber fazer postes sagrados, instrumentos musicais, máscaras rituais, pinturas corporais, casas, redes, arco e flecha de caça, bem como saber pescar, caçar e cozinhar, ou seja, todas as atividades culturais - é compartilhado com os homens durante a realização dos ciclos cerimoniais, época em que os espíritos voltam à terra e habitam entre os homens, em suas aldeias (Álvares, 1992).

Álvares (1992: 97) relata que "os yãmiy levam uma vida no além muito semelhante à dos humanos". Lá, fazem roça, caçam, pescam, cozinham seus alimentos, reúnem-se para cantar, casam e fazem filhos. Álvares (1992: 100) destaca que os yãmiy são "excelentes caçadores e pouco necessitam plantar para alimentarse". Não obstante as semelhanças com o mundo dos Maxakali, a autora ressalta que "o além é um lugar livre de todo mal, onde a morte não existe, não há doenças, velhice e tampouco conflitos" (Álvares, 1992: 97), pois os parentes e os afins consanguinizados são definitivamente separados dos afins inimigos, vivendo em aldeias distantes.

Os yãmiy realizam movimentos verticais, isto é, transitam do além para a terra, enquanto os Maxakali e as outras categorias que ainda não sofreram a transformação da morte realizam apenas movimentos horizontais. O movimento entre os dois mundos, realizado pelos yãmiy, é que reúne ou dispersa os seres humanos. Por outro lado, a transferência para o eixo vertical das categorias que antes se movimentavam apenas no eixo horizontal é provocada pelo movimento dos yãmiy puknõy (yãmiy estranhos) que instigam assassinatos e ocasionam doenças que conduzem à morte, promovendo o movimento do koxuk para o além (Álvares, 1992).

O fluxo correto do yãmiy implica o próprio processo de construção do conhecimento e da recriação e reordenamento da tradição. O conhecimento pertence aos espíritos, e os homens só têm acesso a eles por meio da realização dos ciclos cerimoniais chamados yãmiyxop. O que permite a atualização do conhecimento é a relação entre os espíritos e os humanos.

As considerações de Álvares, Nascimento e Torretta nos levam a constatar que os Maxakali vivem dificuldades para reproduzir sua existência em bases tradicionais. De um lado, por questões de sobrevivência, são impelidos a alterar suas antigas formas de produção, e, de outro lado, uma vez que isso lhes causa grande insatisfação, são compelidos a tentar restaurá-las caçando os bois dos fazendeiros vizinhos. Contudo, a segunda alternativa encontrada também não é satisfatória, pois desperta a ira dos donos dos bois, estabelecendo o conflito entre os fazendeiros, os jagunços e os Maxakali.

Para Horton (1965), o caráter da ansiedade que motiva o beber nas sociedades da amostra estudada está ligado à economia de subsistência, ou seja, à insegurança de subsistência e à aculturação. Entre os Maxakali, o acento deve ser colocado sobre a sua plena reprodução social, o que envolve a sua cosmologia, uma 
economia cujo escopo é a fabricação de pessoas, e não somente a questão da sobrevivência física. De certo modo, pode-se sustentar que a economia deles é adequada à satisfação mínima de suas necessidades, uma vez que eles estão crescendo demograficamente. Entrementes, vale salientar o senão que Álvares (1995) e Silva (1996) assinalam sobre a economia maxakali, no sentido de que a escassez de caça estaria reduzindo o regime proteico deles e, por conseguinte, acarretando um quadro de desnutrição entre as crianças da etnia.

Pelo que foi exposto sobre a cosmologia maxakali, verifica-se que há uma incompatibilidade entre os conhecimentos que os yãmiy compartilham com os membros da etnia e o estilo de vida construído a partir do contato interétnico. Álvares (1992) nos mostra que é através da relação com os yãmiy que os Maxakali aprendem a ser caçadores. Os yãmiy são, por excelência, caçadores e partilham este saber com eles. No entanto, conforme foi relatado, a colonização da região originalmente habitada pelos Maxakali provocou-lhes o confinamento numa terra indígena e a escassez da caça tanto na terra indígena quanto fora dela. Esses fatos sugerem que a ansiedade que leva os Maxakali a consumir as bebidas de alto teor alcoólico pode estar relacionada com a não correspondência entre a visão de mundo que os orienta e as novas condições adaptativas que foram e estão sendo construídas a partir da chegada do não índio.

Todavia, parece que esse não é o único contexto que gera a ansiedade entre os Maxakali. Retomando a teoria de Horton (1965), um dos argumentos do autor é que a embriaguez libera impulsos agressivos e que, na ausência das bebidas alcoólicas, eles são normalmente inibidos. À luz desse argumento, procura-se focalizar novamente o povo Maxakali.

Diversos autores (Pena G Las Casas, 2004; Soares, 1998; Silva, 1996; Popovich, 1994; Álvares, 1992; Nascimento, 1984; Amorim, 1980; Rubinger, 196263) relataram a guerra ou conflitos entre os Maxakali, na maioria das vezes violentos, passando ao longo do século XX, desde os anos 1930, até o início do século XXI. Álvares observa que após a deflagração de um conflito os grupos envolvidos migram, de modo a permanecerem o mais distante possível. Também destaca que, quando ocorre a pilhagem, prática constante, principalmente entre inimigos ou estranhos, a responsabilidade pelos roubos recai sobre as crianças, a fim de evitar um conflito direto entre as partes envolvidas (Álvares, 1992).

Analisando os relatos de Pena e Las Casas (2004), Soares (1998), Silva (1996), Popovich (1994), Álvares (1992), Nascimento (1984), Amorim (1980) e Rubinger (1962-63), verifica-se que a manifestação agressiva dos Maxakali está relacionada ao consumo de bebidas de alto teor alcoólico. A exceção ocorre quando um crime é cometido. Popovich (1994: 29) observa que "o parente da vítima tem o direito e a responsabilidade de 'pagar' por essa morte, matando aquele considerado responsável". 
Diante desses fatos, fica clara a existência de um código cultural na sociedade maxakali que prevê a vingança e que funciona como um mecanismo que promove a inibição da manifestação agressiva entre os seus membros. A inibição é resultante de castigos socialmente aplicados pelos Maxakali, segundo suas crenças, a certas condições estabelecidas de ação, sobretudo condutas agressivas que causam prejuízo a outrem. Esse código cultural torna-se evidente quando Popovich (1994) faz sobressair que, para os Maxakali, o assassinato e a feitiçaria que provocam o fim do outro são crimes que devem ser pagos com a morte do infrator.

Então, pode-se dizer que o povo Maxakali estimula a inibição de impulsos agressivos através de um código cultural que prevê a vingança, e este quadro pode provocar o surgimento de uma ansiedade vinculada ao temor de incitar o ressentimento ou a cólera no outro. De outro modo, a assertiva é que aqui a ansiedade que estimula a ingestão de bebidas de alto teor alcoólico entre os Maxakali está sendo engendrada por esse código cultural que exerce o controle social neste povo.

\section{Consolidando significados}

Apresentaram-se dois contextos que mostram como a ansiedade pode surgir no cotidiano dos Maxakali e estimular o consumo de bebidas destiladas. Entretanto, resta discutir sobre o motivo que os levou a apropriar-se delas, ou melhor, domesticá-las. A fala de João Santana, indígena maxakali que vive em Água Boa, associada aos dados reunidos até aqui, pode nos ajudar a compreender isso. João Santana, de acordo com Soares (1998: 9), diz o seguinte sobre as bebidas alcoólicas: "Tá bebendo aqui. Mas não tá triste. Tá passeando. (...) Se tikmu'um ficar ugãy...12 aí tá bom não. Se ficar alegre, tá bom. Tá passeando".

Nessa fala há um lado lúdico. João Santana enfatiza a alegria e o passear, palavras que nos remetem à cosmologia maxakali, mais precisamente ao mundo dos yãmiy, o mundo idealizado pelo povo Maxakali. A bebida, segundo o depoimento, possibilitaria aos Maxakali a aproximação com este mundo ideal. Com efeito, uma hipótese é que as bebidas destiladas, uma vez integradas ao cotidiano maxakali, podem vir a mediar a incongruência entre o estilo de vida ideal maxakali que é difundido nos cantos pelos yãmiy e o estilo de vida sedentário forjado pelo contato. Consumir essas bebidas pode permitir aos Maxakali escapar, momentaneamente, do sedentarismo e deixá-los alegres ${ }^{13}$.

Para encerrar este capítulo, procura-se agora esboçar uma hipótese de como pode ser compreendido o lado nebuloso da fala de João Santana. Ele diz: "Se tikmu'um ficar ugãy... aí tá bom não". No trabalho de Nascimento (1984), uma frase chama a atenção. O discurso citado a seguir é atribuído aos Maxakali quando procuram justificar os assassinatos cometidos sob os efeitos das bebidas de alto teor alcoólico: "Fulano bateu ou matou porque estava com a cabeça doida" 
(Nascimento, 1984: 31). Do mesmo modo, o relato de Álvares (1992: 100) sobre os yãmiy puknõy (yãmiy estranhos) é muito interessante e parece ter uma conexão com a citação anterior:

Os Maxakali diziam-me que são os assassinos que se transformam nestes últimos yãmiy, mas apenas aqueles que não "usam a razão", ou seja, que agem pelo que caracteriza o estado ugãy - a ferocidade incontrolada e a inconsciência, a loucura. E esta loucura é atribuída à atuação dos próprios yãmiy puknõy. Eles penetram na cabeça e dominam a pessoa, instigando-a a cometer o assassinato.

Pode-se observar, são dois discursos distintos, um encaixado no outro. O segundo nos diz que os yãmiy estranhos ${ }^{14}$ entram na cabeça da pessoa e induzemna a agir de forma violenta, não racional. O primeiro parece confirmar o segundo discurso, pois afirma que o ato de violência é cometido porque a pessoa fica com a cabeça doida, ou, para usar um outro termo equivalente e expresso na língua maxakali, fica ugãy (louco). E, como se viu, a loucura é provocada pela atuação dos yãmiy estranhos. Além do mais, o primeiro discurso sugere que o que propicia a entrada dos yãmiy puknõy na cabeça dos Maxakali é a bebida destilada.

De tal sorte, pode-se inferir que, nesse caso, tais bebidas possibilitam a produção de inimizades, crimes. Elas são responsáveis, mesmo que indiretamente, pela desordem, pela violência, pela manifestação de toda a hostilidade maxakali contida, sob a forma de agressão física aberta, que no estado sóbrio é inibida e subjugada por uma aparência de amistosidade. Acredita-se que era a isso que João Santana estava se referindo em sua fala.

Sabe-se que ainda é necessário investigar com detalhes, com base em pesquisa de campo, o papel e os efeitos desencadeados pelas bebidas de alto teor alcoólico entre o povo Maxakali, procurando evitar substituir o pensamento deles pelo nosso e atribuir outros sentidos às palavras que empregam. Por ora, a partir do material bibliográfico com o qual se trabalhou, acredita-se poder inferir que as bebidas de alto teor alcoólico podem ser vistas como veículos que criam tanto a possibilidade de um desencontro entre os próprios Maxakali - isto quando tikmu'um ficar ugãy como de um encontro com o mundo idealizado por eles - se tikmu'um ficar hitup. ${ }^{15}$

Notas

1 Este capítulo é uma versão revisada de: Pena, J. L. Os índios Maxakali: a propósito do consumo de bebidas de alto teor alcoólico. Revista de Estudos e Pesquisas, 2(2): 99-121, 2005. Texto republicado com autorização do autor e do editor da revista.

2 Pode-se, grosso modo, classificar as bebidas alcoólicas em fermentadas, como a cerveja, o vinho, o cauim, a chicha, e em destiladas, como o uísque, o conhaque, a cachaça, o rum, o gim e a vodka, aqui denominadas bebidas de alto teor alcoólico. É importante observar que, entre os 
povos indígenas, as bebidas destiladas foram disseminadas a partir da chegada dos conquistadores europeus.

3 Segundo Popovich (1980: 15), o termo maxakali "não surgiu do próprio povo, pois nem consegue pronunciá-lo com facilidade". O termo usado para autodesignação é Tikmu'um.

4 Dados retirados do projeto de pesquisa "Enteroparasitoses e Desnutrição Infantil nas Terras Indígenas de Minas Gerais: Krenak e Maxakali", desenvolvido pelo Laboratório de Epidemiologia de Doenças Parasitárias do Departamento de Ciências Médicas da Escola de Farmácia da Universidade Federal de Ouro Preto, no período de outubro de 2007 a outubro de 2009.

5 Bebida fermentada preparada pelos indígenas com mandioca ou milho mastigados, às vezes com diversas frutas.

6 Segundo Álvares (1992: 96-97), os yãmiy são os seres "donos do canto, das belas palavras" e "levam uma vida no além muito semelhante à dos humanos".

7 Em vigor até os dias de hoje, a lei n. 6.001, promulgada em 1973 e que ficou conhecida como Estatuto do Índio, dispõe sobre as relações do Estado e da sociedade brasileira com os índios. Consta do seu artigo 58, III, que "constitui crime contra os índios e a cultura indígena propiciar, por qualquer meio, a aquisição, o uso e a disseminação de bebidas alcoólicas nos grupos tribais ou entre índios não integrados". (Brasil, 1973)

8 O ritual de iniciação masculina (puberdade) ocorre por volta dos 6 ou 7 anos e está relacionado à mudança do pertencimento da esfera doméstica (feminina) para a pública cerimonial (masculina). Para o sexo feminino, não existe ritual de passagem. Nem mesmo a primeira menstruação significa a passagem de uma fase para outra, uma vez que elas podem se casar mesmo antes da menarca (Álvares, 1992). Em outras palavras, os indígenas Maxakali ingressam na vida adulta precocemente, contraindo matrimônio na pré-adolescência.

9 Essa bebida foi incorporada ao vocabulário maxakali e kaxmuk é a palavra que eles utilizam para denominá-la no idioma indígena (Bicalho, s.d.).

10 Álvares (1992) salienta que estas incursões estão relacionadas com a caça de animais de porte.

11 Yãmiyxop, além de ser "o termo utilizado para designar os próprios rituais", constitui um "amplo panteão de espíritos cantores que se relacionam a quase todo o universo Maxakali, incluindo as almas de seus próprios mortos - moram também em aldeias e ocupam uma região bem mais ampla, porém mais afastada dos homens" (Álvares, 1992: 89-90).

12 Conforme Bicalho (s. d.), ugãy significa feroz, loucura, falta de razão, selvagem.

13 Torretta (1997) destaca que as entrevistas semiabertas e abertas realizadas com os Maxakali permitiram evidenciar que a principal projeção associativa relacionada com o consumo de bebidas alcoólicas é a alegria.

14 Segundo Álvares (1992: 119), "A noção de estranho é concebida pelos Maxakali como potencialmente perigoso e violento, com uma forte conotação de inimizade".

15 Hitup, de acordo com Bicalho (s. d.), significa "alegria, alegre". "Alegria é o sintoma do equilíbrio, tanto biopsicológico como social". 
Referências

ÁlVARES, M. M. Yãmiy, os Espíritos do Canto: a construção da pessoa na sociedade Maxakali, 1992. Dissertação de Mestrado, Campinas: Programa de Pós-Graduação em Antropologia Social da Unicamp.

ÁlVARES, M. M. (Org.). Campanha Internacional pela Regularização do Território Maxakali. Belo Horizonte: Realização Povo Maxakali, Cimi-Leste, Cedefes, DKA-Áustria, 1995.

AMORIM, M. S. Os Maxakali e os brancos. In: RUBINGER, M. M.; AMORIM, M. S. G MARCATO, S. A. (Orgs.). Índios Maxakali: resistência ou morte. Belo Horizonte: Interlivros, 1980.

BICALHO, C. Minidicionário Maxakali-Português. Belo Horizonte, s. d. (Mimeo.). (Fruto de uma pesquisa de iniciação científica desenvolvida com bolsa do CNPq durante graduação na Fale/UFMG, de 1996 a 1998).

BRASIL. Lei 6.001, $19 \mathrm{dez}$. 1973. Dispõe sobre o Estatuto do Índio. Disponível em: <www.planalto.gov.br/ccivil_03/leis/16001.htm>. Acesso em: 18 abr. 2013

CÂMARA CASCUDO, L. Prelúdio da Cachaça. Belo Horizonte: Itatiaia, 1986.

HORTON, D. As funções do álcool em sociedades primitivas. In: KLUCKHOHN, C.; MURRAY, H. A. G SCHNEIDER, D. M. (Orgs.). Personalidade na Natureza, na Sociedade e na Cultura. v. 2. Belo Horizonte: Itatiaia, 1965.

MARCATO, S. A. O indigenismo oficial e os Maxakali (séculos XIX e XX). In: RUBINGER, M. M.; AMORIM, M. S. G MARCATO, S. A. Índios Maxakali: resistência ou morte. Belo Horizonte: Interlivros, 1980.

MAXIMILIANO, Príncipe de Wied-Neuwied. Viagem ao Brasil. Belo Horizonte, São Paulo: Itatiaia, EdUSP, 1989.

NASCIMENTO, N. F. A Luta pela Sobrevivência de uma Sociedade Tribal do Nordeste Mineiro, 1984. Dissertação de Mestrado, São Paulo: Programa de Pós-Graduação em Ciências Sociais da Universidade de São Paulo.

NIMUENDAJÚ, C. Índios Maxakali. Revista de Antropologia, 6(1): 209-218, jun. 1958.

PENA, J. L. G LAS CASAS, R. Relatório de Viagem: considerações sobre os conflitos recentes vividos pela sociedade Maxakali. Belo Horizonte: DSEI/Fundação Nacional de Saúde, 2004.

PEREIRA, E. M. M. Reorganização Social no "Noroeste do Amazonas": elementos sobre os casos Huitoto, Bora e Ticuna, 1999. Dissertação de Mestrado, Rio de Janeiro: Programa de Pós-Graduação em Antropologia Social do Museu Nacional.

POHL, J. E. Viagem no Interior do Brasil. Belo Horizonte, São Paulo: Itatiaia, EdUSP, 1976.

POPOVICH, F. B. A Organização Social dos Maxakali. Brasília: Sociedade Internacional de Linguística, 1994.

QUEIROZ, C. C. Punição e Etnicidade: estudo de uma "colônia penal indígena", 1999. Dissertação de Mestrado, Belo Horizonte: Programa de Pós-Graduação em Sociologia da Universidade Federal de Minas Gerais. 
RIBEIRO, D. Os Índios e a Civilização. São Paulo: Círculo do Livro, s. d.

RUBINGER, M. M. Projeto de Pesquisa Maxakali: diário de campo. Aldeias Água Boa e Pradinho, 1962-63. (Manuscrito)

RUBINGER, M. M. Maxakali: o povo que sobreviveu - estudo de fricção interétnica em Minas Gerais. In: RUBINGER, M. M.; AMORIM, M. S. G MARCATO, S. A. Índios Maxakali: resistência ou morte. Belo Horizonte: Interlivros, 1980.

SAINT-HILAIRE, A. Viagem pelas Províncias do Rio de Janeiro e Minas Gerais. Belo Horizonte, São Paulo: Itatiaia, EdUSP, 1975.

SILVA, A. L. O Lugar da Criança Maxakali: estudo do processo educacional de uma sociedade indígena. São Paulo: Universidade de São Paulo, 1996. Relatório de pesquisa de campo. (Mimeo.)

SIMONIAN, L. T. L. Alcoolismo entre Indígenas: a persistência de uma realidade dolorosa e destruidora. Belém, 1996. (Mimeo.)

SOARES, G. C. Os Maxakali e a Questão do Alcoolismo: contribuição para uma discussão interna. s. 1.: Cimi/Cedefes, 1998. Relatório. (Mimeo.)

TORRETTA, O. Uso e Abuso de Substâncias Alcoólicas ao Interno do Grupo Indígena Maxakali. Belo Horizonte: Departamento de Sociologia e Antropologia da UFMG, 1997. Relatório. (Mimeo.) 


\section{Controle Social como Autoatenção: estratégias kaingang diante do abuso de bebidas alcoólicas}

Ari Ghiggi Junior e Esther Jean Langdon

Este capítulo, baseado em pesquisa etnográfica na Terra Indígena Xapecó (TIX) de Santa Catarina, ${ }^{1}$ examina o processo de 'alcoolização' entre os índios Kaingang na perspectiva antropológica. Em vez de partir do anacrônico conceito de 'alcoolismo', que parece ainda impregnar as políticas públicas de saúde, ${ }^{2}$ exploramse os entendimentos elaborados pelos próprios Kaingang sobre as formas adequadas e não adequadas de consumir bebidas alcoólicas, com enfoque nas formas impróprias de uso ligadas à moralidade local. A partir da compreensão do contexto que abarca tais condutas, examinam-se as práticas de autoatenção utilizadas pela comunidade para o consumo e a regulação do álcool.

\section{Alcoolismo e acusação}

Desde a década de 1990 a discussão oficial da Fundação Nacional de Saúde (Funasa) em programas voltados para os povos indígenas parte do ponto de vista de que o problema do consumo abusivo de álcool está essencialmente vinculado a uma questão de saúde mental e é entendido como 'alcoolismo'. Atualmente essa noção que remete às práticas de beber como uma doença individual, de apresentação invariável e de curso natural e crônico, tem se mostrado problemática até mesmo em setores mais avançados da biomedicina (Souza G Garnelo, 2006). ${ }^{3}$ A perspectiva da Organização Mundial da Saúde (OMS), por exemplo, não alude mais ao termo alcoolismo, mas classifica uma série de "transtornos mentais e do comportamento decorrentes do uso de substâncias psicoativas": intoxicações, síndrome de dependência, síndrome amnéstica, estados de abstinência e transtornos psicóticos (OMS, 1993: 69-70).

Apesar das reformulações, a abordagem biomédica não extrapola a ideia das substâncias alcoólicas como causa de enfermidades identificáveis. As soluções buscadas para o consumo excessivo de bebidas alcoólicas, por meio da explicação e da categorização do sofrimento associado, acabam reduzindo um fenômeno extremamente complexo, apresentado de forma contundente em contextos culturalmente diferenciados (Langdon, 2001). 
A identificação de alcoolismo como doença emergiu na metade do século XIX no Brasil através de um processo de 'doentificação' de um costume popular decorrente da mudança dos padrões sociais, políticos e econômicos estabelecidos desde o fim do século anterior (Santos, 1993). Para Santos, o conhecimento biomédico consolidou um forte alicerce para uma ordem higienista que procurava justificar a coibição do uso de bebidas alcoólicas no país e a difusão dos valores da classe burguesa. Atualmente a atribuição de alcoolismo como um problema dos povos indígenas é comum tanto entre os profissionais da saúde (Melo, Maciel G Neves, 2009; Figueiredo, 2000), quanto entre a população geral, e serve habitualmente de justificativa para a marginalidade e estigmatização das populações como uma forma acusativa, muito mais que o diagnóstico de uma patologia (Neves, 2004).

\section{Alcoolização e autoatenção: o olhar antropológico}

A perspectiva antropológica preocupa-se com a complexidade e com a heterogeneidade deste fenômeno e mostra a necessidade de se entender o que se bebe, como se bebe e quando se bebe nos contextos singulares (Langdon, 2001). Esses contextos de consumo refletem particularidades socioculturais que são importantes na emergência dos sentidos específicos dados às bebidas. O estado de embriaguez não se manifesta igualmente em todos os grupos, sendo necessário considerar os valores culturais como fatores determinantes nas diferenças de estilos de beber e de agir quando se bebe.

É necessário compreender que o uso contemporâneo de bebidas entre os povos indígenas, particularmente o dos destilados, nem sempre reflete os usos tradicionais marcados pelo controle e pelos limites socioculturais. É importante examinar a inserção das sociedades indígenas em contextos assinalados por relações interétnicas de dominação e de contato nem sempre pacificamente estabelecidos (Kunitz G Levy, 1994). Assim, para além das diferenciações entre padrões e formas de beber, a compreensão dos problemas relacionados ao uso de álcool (Souza $G$ Garnelo, 2006) entre indígenas exige que se desloque a temática do campo físico/ individual para o campo coletivo/social, no qual as práticas de beber são pensadas como um fenômeno construído ao longo do tempo e da história do contato do índio com a sociedade envolvente. A perspectiva antropológica volta-se, então, para a observação da intersecção entre expectativas, atitudes e outros fatores sociais e culturais associados ao uso dessas substâncias.

Seguindo outras pesquisas antropológicas sobre o uso de bebidas alcoólicas entre povos indígenas no Brasil (Acioli, 2002; Souza, 2004), ${ }^{4}$ esta análise se apoia nas considerações de Eduardo Menéndez e em seu conceito de processo de alcoolização definido como: 
o conjunto de funções e consequências positivas e negativas que cumpre a ingesta de álcool para conjuntos sociais estratificados e não apenas o estudo dos alcoólicos dependentes, nem os excessivos, nem os moderados, nem os abstêmios, mas sim o processo que inclui todos e que evita considerar o problema em termos de saúde e/ou enfermidade mental. (apud Souza, 2004: 27)

A conceitualização desse fenômeno como processo parte de um conceito inclusivo dos atores e processos sociais e aponta para o conjunto dos aspectos positivos e negativos relacionados à presença das bebidas alcoólicas em determinado contexto cultural. Neste capítulo, contudo, a ênfase será dada aos aspectos negativos envolvidos no uso das bebidas alcoólicas expressados pelos próprios indígenas que decidem o que deve ser incentivado, tolerado, mantido ou reprimido.

Outro conceito explorado na análise, o de 'autoatenção' (Menéndez, 2009), permite perceber os esforços da comunidade para prevenir ou controlar o que é entendido como ameaçador ou preocupante para o bem do grupo. As atitudes locais podem ser consideradas como práticas deste tipo, tomadas com a intenção de deslocar o olhar da noção de enfermidade em sentido biomédico e retomar a busca de recuperação dos significados que os conjuntos sociais atribuem a seus padecimentos, problemas e sentimentos. Autoatenção refere-se às:

representações e práticas que a população utiliza tanto individual quanto socialmente para diagnosticar, explicar, atender, controlar, aliviar, suportar, curar, solucionar ou prevenir os processos que afetam sua saúde em termos reais ou imaginários, sem a intervenção central, direta e intencional de curadores profissionais, embora eles possam ser os referenciais dessa atividade. A autoatenção implica decidir a autoprescrição e o uso de uma terapêutica autônoma ou relativamente autônoma. (Menéndez, 2009: 48)

Menéndez valoriza a atuação do grupo como eixo de saneamento das situações indesejadas, o qual se torna o alvo do processo de autoatenção. Esse processo possui dois níveis segundo o autor: um em sentido 'estrito', que diz respeito às atitudes intencionais calcadas nas decisões das pessoas no enfrentamento dos infortúnios, e outro em sentido 'lato' (ou amplo), que diz respeito às atitudes que visam a assegurar a reprodução biossocial do grupo como um todo. Tal concepção ajuda a compreender as estratégias utilizadas pelos Kaingang nas situações indesejadas relacionadas à utilização de bebidas alcoólicas.

\section{A Terra Indígena Xapecó}

As terras que hoje formam a TIX foram requeridas pelo cacique Vahnkrê como pagamento pelo trabalho de abertura de uma trilha, para instalar uma linha telegráfica, executado entre 1890 e 1893 (Manfroi, 2008). O título definitivo das 
terras em meados da década de 1940 resultou na transferência de indígenas do Paraná para a localidade numa movimentação violenta e danosa sem o consentimento dos envolvidos (Almeida, 1998). O território reservado, inicialmente com 50.000 hectares de área entre os rios Chapecó e Chapecozinho, foi reduzido a cerca de 15.000 hectares na década de 1960 (Nacke, 1983; Almeida, 1998).

Essa complexa e conturbada etapa de constituição aconteceu junto ao processo de derrubada e comercialização da mata de araucária (Araucaria angustifolia) e imbuia (Ocotea porosa) característica da região. O Serviço de Proteção aos Índios (SPI), por intermédio do chefe do posto, foi o responsável pela extração da madeira e pelas grilagens das terras vendidas a descendentes de italianos oriundos do Rio Grande do Sul (Almeida, 1998). Somente em 1978 foram tomadas providências para a retirada dos invasores, "ficando para trás um rasto de compadrio, aliança e casamento entre colonos e índios cujas marcas estão visíveis nas faces de quem permaneceu no local" (Almeida, 1998: 15).

A TIX está atualmente localizada nos municípios de Ipuaçu e Entre Rios, oeste de Santa Catarina. Segundo o último censo, a população total da TIX era de 4.056 indígenas (Brasil, 2012). Ipuaçu, que comporta a maior parte do território da TIX, contava com um total de 3.436 indígenas (Brasil, 2012), pouco mais que a metade da população total do município (6.798 habitantes). ${ }^{5}$ Entre Rios possuía população total de 3.018 habitantes, ${ }^{6}$ dos quais 620 eram indígenas (Brasil, 2012).

A pesquisa concentrou-se nas aldeias Sede e Pinhalzinho, as mais populosas da TIX. A primeira, com cerca de 1.500 habitantes, possui uma infraestrutura que a diferencia das demais, pois concentra algumas instituições burocráticas importantes como o posto da Fundação Nacional do Índio (Funai), a escola de ensino fundamental e médio, o ginásio de esportes em formato de tatu, a casa da cultura, uma escola de ensino infantil e um posto de saúde relativamente bem equipado. A aldeia é cortada por uma via de terra não pavimentada que liga o município de Entre Rios ao de Bom Jesus. A segunda, com cerca de 1.200 habitantes, está localizada a mais ou menos sete quilômetros do centro de Ipuaçu. Possui uma escola de nível fundamental, um posto de saúde e é atravessada pela rodovia SC-480 que apresenta intenso trânsito de automóveis que circulam entre Ipuaçu e Bom Jesus (Figura 1). 
Figura 1 - Localização das aldeias na TIX

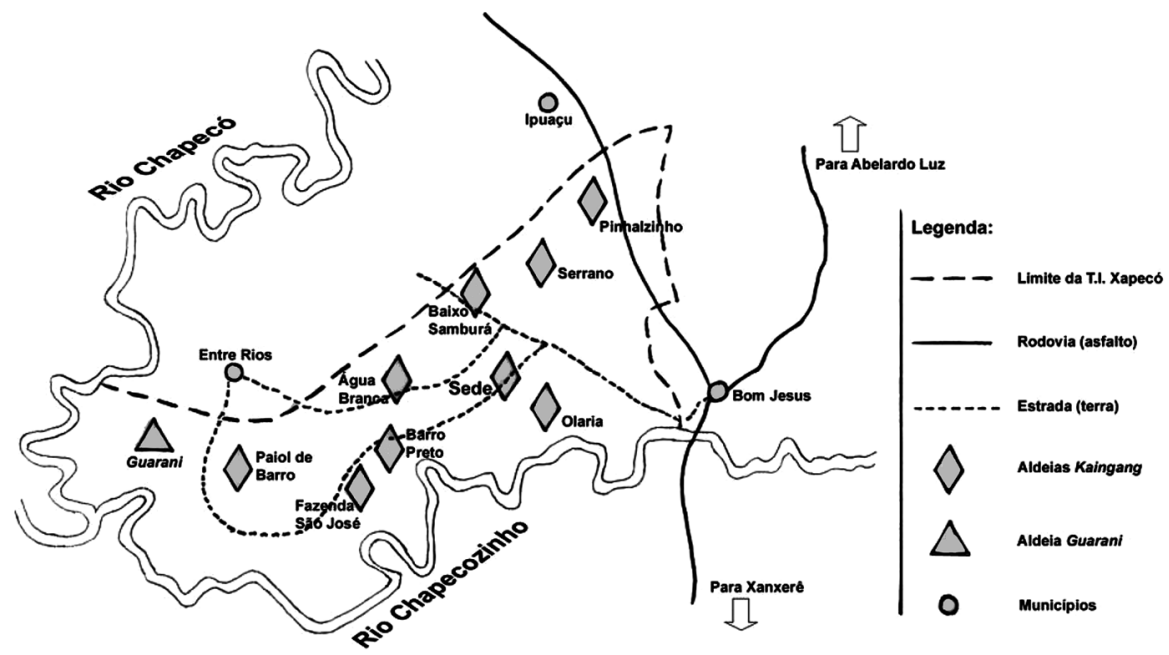

Fonte: Diehl (2001).

Uma importante característica da vida religiosa dos Kaingang da TIX é a configuração de dois grupos ideológicos. De um lado, estão os 'católicos', cuja tentativa de implementação dos ideais se deu durante missões catequéticas que se prolongaram desde o final do século XIX até meados do século XX. A incorporação dos elementos simbólicos relativos a essa concepção religiosa se deu de maneira fluida, adaptando-se àqueles que os índios Kaingang chamam de 'tradição'. ${ }^{8} \mathrm{~A}$ atuação dos monges capuchinhos do Paraná, no oeste catarinense, se deu de forma um tanto autônoma com relação à ortodoxia oficial dessa ordem religiosa, sendo influenciada e absorvida pela cosmologia e ritualística indígena (Veiga, 2004).

De outro lado estão os 'crentes', referência feita localmente àqueles que seguem às denominações evangélicas pentecostais ali instaladas. As primeiras missões nas áreas indígenas kaingang datam da década de 1940 com expansão expressiva no final da década de 1970 e meados da década de 1980 (Almeida, 1998; Veiga, 2004). É impossível a quem visita a localidade deixar de notar a grande quantidade de igrejas e a relativa variedade de denominações que essa expressão religiosa estabelece em quase todas as aldeias da TIX, principalmente em Pinhalzinho e Sede. ${ }^{9}$

A abordagem da percepção e do uso de bebidas alcoólicas se desenvolveu com base em técnicas qualitativas de pesquisa em antropologia. A participação e a observação no e do contexto, bem como o registro em diário de campo, mostraramse fundamentais. Na tentativa de rastrear os espaços que poderiam propiciar uma interação mais efetiva com o aspecto do consumo das substâncias alcoólicas, foram acompanhados eventos como 'bailes' e jogos de 'campeonatos' e 'torneios' de futebol que ocorriam dentro da TIX. Diversas associações cotidianas em torno das 
bebidas alcoólicas levaram a estender a observação a bares, mercados e outros estabelecimentos ligados ao comércio nas localidades urbanas próximas, como Xanxerê, Ipuaçu e Bom Jesus. Por esse motivo, o estudo pretende-se 'multisituado' (multi-sited), com a preocupação num primeiro momento em 'seguir a coisa' (follow the thing) (Marcus, 1998), nesse caso, as bebidas alcoólicas.

Na TIX os indígenas falavam muito sobre bebidas alcoólicas, expressando queixas associadas a determinados modos de usar estas substâncias, as quais apareciam quase que espontaneamente quando eram informados da temática da pesquisa. A partir dessas pistas, foram coletados discursos locais sobre os problemas relacionados ao uso de álcool. Surgiu, então, a preocupação em situar os discursos produzidos, marcando a posição de grupos ou atores naquilo que se poderia chamar de estrutura sociológica da TIX. Conversas com as lideranças políticas e religiosas foram altamente valorizadas, como também a participação em diversos rituais religiosos dos crentes e a observação das atuações das lideranças indígenas.

As narrativas ou depoimentos dos indígenas que caracterizam situações constrangedoras envolvendo o uso de bebidas alcoólicas foram tratados com cuidado. A mediação pelo Código de Ética do Antropólogo ${ }^{10}$ aciona a garantia de direitos relacionados tanto ao pesquisador quanto à população envolvida, projeto baseado em posições como a de Cardoso de Oliveira (2004), que compreende a relação entre pesquisador e sujeitos em campo como uma construção mediada por uma relação dialógica constantemente negociada. Uma pesquisa dessa natureza temática toca em aspectos delicados da vida social. Daí ser fundamental a preservação de informações que remetam à intimidade do grupo de acordo com os padrões culturais. Para tal, não há identificação dos interlocutores nas descrições apresentadas.

\section{A percepção dos Kaingang sobre a problemática}

Os Kaingang do oeste catarinense podem ser facilmente caracterizados pela sua cotidiana circulação pelos municípios da região e pelo estabelecimento de diversos modos de relacionamentos com os não indígenas. Demonstram presença marcante no comércio local, como efetivos clientes dos estabelecimentos que ofertam os mais diversos bens de consumo nas cidades vizinhas. Nessas interações o acesso às bebidas alcoólicas é facilitado, ao mesmo tempo que medeia e motiva algumas das investidas dos indígenas nessas localidades, outorgando às substâncias um importante papel nos modos de sociabilidade entre as populações em questão.

Não há consenso quanto ao fato de o consumo das bebidas alcoólicas sempre ser problemático. Elas aparecem como principais motivadoras para a participação da população indígena nos eventos de 'jogos de futebol' e 'bailes' no interior da TIX. Não significa que não existam pessoas interessadas apenas em assistir às partidas ou dançar, mas, como relatam alguns indígenas: "não adianta 
ter jogo se não tem cerveja, o povo não vai". Esses espaços específicos e esporádicos, onde a comercialização da bebida alcoólica no interior da reserva tem consentimento e incentivo das lideranças indígenas, são considerados momentos essenciais de confraternização pela população em que se podem consumir as substâncias amenizando possíveis estigmatizações.

Além dessas motivações mais aparentes ligadas à diversão, as bebidas alcoólicas também aparecem com outras finalidades na TIX. A cachaça é muito utilizada por alguns indígenas quando desejam trabalhar nas roças, principalmente quando ocorre a prática do 'puxirão' - ou plantio coletivo. A utilização de cerveja de forma terapêutica também pôde ser percebida, como no caso relatado em que foi administrada a uma criança que estava numa situação de nervosismo e desespero.

Em contraponto a esses modos construtivos de utilização, coerentes com a proposta de abordagem de Douglas (1987), os Kaingang se referem a um tipo específico de usuário de bebidas alcoólicas: o bêudo. Como categoria acusatória acerca de alguns indivíduos específicos, ela diz respeito à marcação de um estilo de vida peculiar. Muito além de denotar um 'estado de espírito', a palavra sinaliza, sem dúvida, alguma espécie de forma abusiva ou imoral envolvida no consumo de bebidas alcoólicas. A pessoa que é taxada com tal característica, na maioria das vezes, é associada a eventos entendidos localmente como indesejados. São diversos discursos que envolvem figuras desse tipo em episódios de violência pública e doméstica, roubo ou outra transgressão.

Uma observação feita em campo é exemplar. Em um dia qualquer do mês de setembro de 2009, subitamente, uma espécie de uivo quebrava o silêncio da noite. Todos que estavam presentes na casa falaram no mesmo momento: "lá vem o bêudo". Levantaram de suas cadeiras onde assistiam à televisão e foram para a janela e para a porta espiar o que estava acontecendo. Na rua, ao longe, dava pra ver um homem andando e cambaleando que ia na direção do posto de saúde. A cada vinte ou trinta segundos o homem soltava um breve grito. Quando chegou à frente do posto de saúde, parou de caminhar e em seguida iniciou uma sequência de golpes de facão no único telefone público existente na aldeia. Permaneceu ali resmungando e batendo no orelhão por mais ou menos trinta minutos. A passagem do homem na rua causou comentários e risadas entre os que estavam na casa, ao mesmo tempo que se mostravam preocupados para que ele não os visse observandoo. Quando o bêudo se afastou da vista deles, voltaram a assistir normalmente ao programa da televisão. A dona da casa começou a brincar com o netinho perguntando-lhe: "Como é que o bêudo faz?". A criança respondia com gritinhos imitando o homem, o que era motivo de risadas dos outros presentes.

O reconhecimento da execução de uma performance corporal pública específica, apontada como desdobramento da ingestão da bebida alcoólica é crucial para esta caracterização, em que o estigma e a acusação emergem da interpretação 
de alguns sinais públicos comunicados ao grupo mais amplo. As aparições públicas dos bêudos figuram como um espetáculo a ser apreciado pela população. Quando alguém nota que há algum barulho fora do comum, especialmente na rua, agilizase para convidar os outros que estão por perto a assistir ao acontecimento e comentálo - o que geralmente acontece em tom de deboche.

Essa categoria também é frequentemente utilizada de maneira didática nos ensinamentos passados às crianças, principalmente sobre os espaços que não devem ser frequentados: "lá tem bêudo". Ou então, para assustá-las quando transgridem alguma norma: "não faça isso senão eu chamo o bêudo". Não se presenciou ninguém sendo acusado diretamente, mas as crianças também utilizavam a expressão para desconsiderar alguma outra criança que possuísse um familiar marcado como tal: "o teu pai é um bêudo!". As crianças também imitam, em determinados momentos de diversão, as performances dos bêudos, principalmente sua forma de andar, gesticular e falar.

'Beber na estrada', apesar de uma prática comum na TIX, é de certa forma concebida como inadequada. É comum o deslocamento de pessoas da Sede até a cidade próxima de Bom Jesus para adquirir e consumir bebidas alcoólicas. Quando estão sem transporte, caminham os 10 quilômetros pela estrada de chão batido que separa o município da aldeia. Indígenas embriagados estão diariamente espalhados por esse caminho, principalmente em alguns locais específicos conhecidos como 'pontos de carona'. Quase sempre as mesmas figuras nos mesmos lugares, às vezes acompanhadas por outras na mesma situação: sentados próximos uns aos outros, em grupos de três a cinco pessoas, bebendo e compartilhando cachaça. A conversa com essas pessoas é frequentemente difícil pelo nível de embriaguez exagerado.

O consumo de bebidas alcoólicas também é intensificado às margens da SC-480, estrada asfaltada que atravessa a aldeia Pinhalzinho. Nos fins de semana, é possível perceber um aumento demasiado do número de pessoas embriagadas em público. Ali também existem pontos específicos de encontro com afins, mas é muito mais comum que os indígenas fiquem circulando enquanto bebem. Frequentemente os alcoolizados dirigem piadas e provocações às pessoas que passam pela estrada em carros ou mesmo a pé. Não foi possível perceber se carregavam bebidas alcoólicas ou se as consumiam especificamente nesse local, mas era evidente a presença de alguns deles dormindo na beira da estrada após seus porres. Os moradores da localidade, ao serem indagados sobre esta prática, eram quase unânimes em acusá-los como bêudos.

Nas aldeias existem caminhos secundários às convencionais estradas. Estes 'carreiros' que cortam o interior dos terrenos ligam pontos das aldeias por atalhos que apenas comportam a passagem de pessoas. Vários deles passam por locais de mata mais fechada ou regiões onde não há casas, zonas propícias para encontrar 
indígenas bebendo sozinhos com seu litro de cachaça particular. Se algum estranho deseja circular por ali, fatalmente é alertado por algum indígena morador das redondezas para tomar cuidado com as atitudes violentas dos bêudos. Entretanto, a maioria desses bêudos esboça mais frequentemente uma atitude evasiva do que de enfrentamento. Beber ou ficar embriagado nos espaços públicos não é bem visto pelos Kaingang, particularmente se a bebida escolhida para consumir for cachaça. O espaço privado, a casa, é a opção mais adequada para o consumo, onde se 'pode beber sem ser incomodado'. Como foi reafirmado pelos consumidores: "se a gente não faz bagunça e não briga, não tem problema em tomar umas".

Assim, o consumo de bebidas alcoólicas e o reconhecimento de problemas a ele associados se configuram como foco de reflexão da população local. O contexto etnográfico da TIX possibilita questionar representações ocidentais estigmatizantes que tendem a encarar a questão da circulação e do consumo de bebidas alcoólicas em terras indígenas com uma natural libertinagem incontida.

Apesar de no caso da TIX a questão da proibição legal ${ }^{11}$ da venda de bebidas alcoólicas para indígenas estar enfaticamente presente nos discursos tanto da população envolvente quanto da população da reserva, o controle mais efetivo sobre as substâncias associa-se a aspectos da política local e à existência de grupos ideológicos internos. Parâmetros sobre os estatutos das bebidas alcoólicas sustentados em alicerces diversos estimulam atuações diferenciadas e até contraditórias para regulação das substâncias em si, das possibilidades e formas de sua utilização e das pessoas que delas desejam se servir. Esses grupos ocupam posições privilegiadas com relação a acesso a poder político e fazem com que especulemos sobre a convivência de diferentes discursos moralizadores sobre o álcool que subsidiam e justificam a própria formalização do alcance dessas microesferas.

\section{Controle pelas lideranças indígenas}

Ricardo Cid Fernandes (1998) traz algumas contribuições sobre a sociedade kaingang, ao abordar as repercussões e atitudes políticas relativas a estes indígenas em uma reserva do Paraná. Além de demonstrar como internamente se modelam os processos de legitimação de esferas de poder, mostra a existência de forte integração dos indígenas nos processos políticos mais amplos, como a filiação a partidos políticos, por exemplo. O que se chama internamente de 'liderança indígena' somente tem sentido se entendido como um corpus com poder legitimado para tomar decisões e atitudes que dizem respeito à manutenção da organização interna do grupo, principalmente no saneamento de alguma situação indesejada, e para representar a sociedade indígena como um todo perante a sociedade envolvente. A posição mais elevada na hierarquia das lideranças indígenas é 
representada pelo 'cacique', figura que centraliza o poder sobre as decisões políticas e medeia o processo para a formação desse corpus local.

Os auxiliares do cacique nas diversas aldeias da TIX são denominados 'capitães', que têm a função de assegurar a segurança mais localizada. Geralmente, as informações circulam fluentemente entre as diversas aldeias da TI, mas essas figuras oficiais constituem poder legítimo para tomar algumas decisões políticas mais emergenciais no nível microssocial e articulá-las com a liderança central. Os capitães são as pessoas a quem a população deve recorrer quando há alguma reclamação ou desordem a ser registrada. Dependendo do nível da queixa ou do evento indesejado, as lideranças indígenas atuam de diversas maneiras em seu saneamento.

Ramos (2008), em seu estudo sobre os Kaingang da bacia do rio Tibagi no Paraná, aborda as atitudes políticas que revelam um sistema judiciário também praticado na TIX. Esse sistema, com poder centralizado nas lideranças, deve cumprir certas etapas para que haja legitimidade das atitudes entre os habitantes. Caso ocorra algum desentendimento entre vizinhos, ou cônjuges, a liderança estabelece o que chama de 'audiência', onde procuram ouvir todas as partes envolvidas para subsequente tomada de decisão quanto ao desdobramento do caso. Geralmente, o nível mais básico da atuação é o 'aconselhamento', o qual é efetuado com cada uma das partes separadamente durante a própria audiência: as lideranças indígenas propõem verbalmente alguma saída relativamente pacífica para os envolvidos. Caso o problema persista e o desentendimento volte a trazer danos para alguma das partes, estas são novamente acionadas pela liderança para medidas mais sérias. Uma delas é a utilização do 'tronco' como meio punitivo.

Assim, enquanto esfera política, as lideranças indígenas atuam para o controle social das bebidas alcoólicas em duas circunstâncias: nas autorizações esporádicas para a comercialização das substâncias dentro da TIX e na coibição de atitudes desagradáveis por parte daqueles que extrapolam as condutas esperadas. Um episódio provocado por um desentendimento em família é ilustrativo a esse respeito. A residência onde habitavam os três membros envolvidos foi palco de muita algazarra e discussão percebida mesmo à distância. Todos estavam embriagados, e um rapaz estava gritando e xingando um casal de idosos. Ele afastouse por um momento e começou a atirar pedras que atingiram o telhado da moradia, afugentando os velhos e obrigando-os a se trancarem no interior da casa. Depois de algum tempo, andou pela estrada e retirou-se por um carreiro que dava acesso ao riacho. Em poucos minutos, três homens representantes da liderança indígena passaram pelo mesmo lugar e dirigiram-se ao encontro do foragido. Voltaram pelo mesmo caminho, segurando o rapaz pelo braço, e levaram-no para a casa de uma das lideranças, o capitão da aldeia, para amarrá-lo a uma árvore que servia de tronco. 
Esse meio de controle era muito utilizado, na maioria das vezes depois de alguma cena de violência denunciada. Quando os acusados estavam embriagados, a sua prisão no tronco era justificada com base na defesa enfática da segurança associada à prevenção de situações graves. A pessoa alcoolizada não fica mais que algumas horas amarrada, até 'se acalmar e passar o porre'. Normalmente, e de acordo com o julgamento feito pelas lideranças indígenas, após esse período está dispensada. A exibição da punição para o público que passa pelas proximidades é essencial, uma vez que quase todos os dias existem pessoas no tronco principalmente cedo pela manhã. Alguns indígenas comentam declarando que "têm dias que até falta tronco de tanta gente (...), aí tem que amarrar um bêudo no outro".

Em situações desagradáveis, como as provocadas pelos bêudos, a reincidência continuada de infrações pode remeter a outras atitudes por parte das lideranças indígenas: a solicitação para o afastamento da aldeia, num primeiro momento, ou, num segundo, a 'transferência' para outra terra indígena. A avaliação para a tomada de medidas mais drásticas acontece esporadicamente em reuniões que envolvem um número considerável de lideranças indígenas, entre elas o cacique.

Além das lideranças indígenas, os crentes elaboram posicionamentos específicos diante da presença das bebidas alcoólicas na TIX, emergindo como um grupo ideológico local importante na atuação sobre esta temática.

\section{Religião como autoatenção}

Existem duas formas de ingresso nas igrejas dos crentes, uma pelo 'nascimento' e a outra pela 'conversão', compreendidas como ritos de passagem (Almeida, 1998). No caso do nascimento de uma criança de pais crentes, são empregados cuidados para que ela seja criada na 'doutrina' e siga uma série de regras durante o período que comunga com tal religião. Essas regras referem-se a alguns aspectos concernentes à própria corporalidade dos indivíduos, como o uso de certas vestimentas (calças e camisas sociais para os homens e saias para as mulheres) e cortes de cabelo (cabelo comprido e amarrado com rabo de cavalo para as mulheres, e curto com a barba benfeita para os homens). São expressamente proibidas certas atividades: participar de jogos e bailes, cometer adultério, dizer palavrões e, principalmente, consumir bebidas alcoólicas. Com 12 anos a criança decide se deseja continuar na igreja e receber o 'batismo'.

Para os que não são nascidos nessa religião a 'conversão' pode ocorrer após uma visitação à igreja motivada por diversas circunstâncias: problemas com o uso de bebidas alcoólicas, doenças ou ainda levado por cônjuge ou familiar. A aceitação como convertido ocorre durante um culto onde o indivíduo é conduzido a rever as falhas cometidas em sua vida reinterpretando eventos passados sob o crivo da 'doutrina' evangélica pentecostal. Idealmente, trata-se de assumir uma 
'nova vida' com o abandono de outras práticas e concepções, não necessariamente indígenas, associadas ao mal (Almeida, 1998).

Um caso exemplar refere-se a um casal que costumava beber em casa durante a noite assistindo à televisão. Segundo eles, compravam cerveja nos mercados das cidades vizinhas e colocavam-na para gelar na sua residência. Era normal que bebessem uma caixa de 12 latinhas em uma única ocasião. Ficavam 'alegres', mas nunca brigavam. Entretanto, em um determinado dia em que estavam cumprindo esse rito íntimo, iniciaram uma discussão por um motivo não relatado, fato que culminou com a separação do casal por alguns dias: ele dormindo na casa da mãe, e ela com os três filhos na própria casa. Esta situação somente foi reparada com um acordo entre as partes em que os dois concordaram que o evento havia sido provocado pelos efeitos da bebida alcoólica. Resolveram manter-se sóbrios a partir daí, e a esposa converteu-se à religião evangélica.

Almeida (1998) relata que a principal atividade dos crentes na TIX é o 'culto', um rito que acontece quase diariamente e é caracterizado por muita música, pregações e orações a Deus. Os crentes, assim como os protestantes em geral, abominam as imagens adoradas pela visão católica e centram sua confiança apenas na 'palavra' embasada nos ensinamentos bíblicos. As únicas entidades que se permitem são Deus e Jesus, quase sempre tratadas como sinônimos. Elas manifestam-se através do Espírito Santo, cuja 'presença' é percebida pela alteração das técnicas oratórias das autoridades religiosas principalmente durante as pregações nos cultos.

Outra característica dos crentes é o proselitismo, tentando convencer os que ainda não aceitaram a 'palavra'. Buscam sempre ênfase na apresentação de uma forma correta de vida e não deixam alternativas para salvação além da entrada no grupo. Nesse sentido, "os 'crentes' buscam estabelecer uma comunidade homestática, na qual o ethos individual associado à reprodução do grupo tenta garantir o seu equilíbrio, construindo a imagem de prosperidade ao nível das relações sociais" (Almeida, 1998: 144).

Na TIX os crentes representam uma das vozes mais eloquentes sobre questões de saúde e moralidade. Frequentemente relatam problemas pessoais mediados pelas bebidas alcoólicas, em que a única solução foi abstinência. Apesar da prática do proselitismo se estender ao cotidiano, o culto é um momento privilegiado de persuasão durante o qual são constantemente enfocadas a oportunidade e a necessidade de firmar a aliança com Jesus. Os discursos ganham ainda mais força através da intensificação da experiência, tanto individual quanto coletiva nos espaços de culto. Os pastores pregam com veemência a substituição da bebida alcoólica pela aceitação da palavra de Deus: 
Você que não consegue fazer nada em casa (...). Você que não tem vontade de trabalhar... Você que tem a bebida todo o dia na sua vida (...). Vem para igreja que aqui Deus vai te curar (...). Vem para igreja que Deus vai interceder (...). Você vai ver que não precisa de bebida, você vai ver que não precisa de álcool, você vai ver que não precisa de droga, porque Deus vai ser tua droga, Deus vai ser tua bebida, Deus vai fazer coisas maravilhosas na tua vida (...). Com Deus na tua vida você não vai precisar de nada disso. Aceita a Jesus porque ele tem um plano para a tua vida (...). Aleluia, glórias a Deus, aleluia. (pastor de uma igreja crente durante um culto)

Casos problemáticos envolvendo a bebida alcoólica são levantados frequentemente pelos pastores, os quais sempre recaem na ênfase de experiências liminares que serviram de estopim para a conversão de certos fiéis. A trajetória de dois irmãos foi relatada exemplarmente por um pastor de uma igreja evangélica. Segundo ele, em uma das corriqueiras ocasiões em que os jovens saíam para beber, esbarraram em uma cerca de arame farpado. O incidente provocou a perfuração de um dos olhos de um dos rapazes e a consequente convocação do pastor à residência dos mesmos. Chegando lá o pastor encontrou um dos irmãos com muitas dores de cabeça; o outro em prantos. Esse último pediu então para que o pastor os ajudasse, afirmando que, se Deus curasse seu irmão, deixaria de beber e se tornaria um dos seus fiéis. O pastor orou fortemente pelo jovem. Depois de alguns dias, o rapaz se recuperou e os dois irmãos começaram a frequentar a igreja. Tornaram-se fervorosos pregadores contra o consumo de álcool, com o testemunho de suas próprias histórias de vida.

O pastor comentou que, meses depois da conversão, um deles havia se 'desviado' da doutrina e se afastado da religião por causa de mais problemas de consumo de álcool. Num momento de descrença na palavra de Deus e embriaguez, envolveu-se num desentendimento que resultou em briga com outro jovem da localidade. O caso culminou no esfaqueamento deste último, o qual teve sérios problemas de saúde decorrentes dos ferimentos. O pastor diagnosticou uma legião de 'sete espíritos malignos' como fomentadora de tais atitudes. O desdobramento do episódio resultou na 'transferência' do agressor e e na conversão do ferido à religião dos crentes.

À luz da doutrina crente, o uso de bebidas alcoólicas remete a um distúrbio em que a própria substância é o receptáculo dos agentes disruptivos: "a cachaça possui 51 demônios nela". Quando os crentes referem-se à bebida alcoólica, retratam as possibilidades de enfraquecimento daqueles que bebem, processo chamado 'perturbação': uma apropriação da pessoa por espíritos que a consomem tanto corporal como espiritualmente - uma vez que no pensamento dos crentes é muito difícil delimitar um e outro no caso de afecção por alguma doença ou infortúnio. 
Da mesma maneira, o discurso dos crentes é em muitas vezes associado aos ideais morais pleiteados pelas lideranças indígenas, uma vez que está subentendido que os convertidos trazem menos problemas devido ao rigor da sua conduta. Pode ser indicado pelas lideranças indígenas, durante os aconselhamentos, que a pessoa se converta à religião crente como meio de conter alguma situação problemática. A eficácia da combinação entre os vieses de atuação dos crentes e das lideranças é cotidianamente enfatizada pela população.

O caso de um casal que se desentendeu é ilustrativo. Segundo o relato, o motivo da discussão deveu-se ao fato de o marido estar 'procurando' outra mulher dentro da área indígena. Passado algum tempo, ao ficar sabendo, a esposa foi tirar satisfações na residência da suposta 'amante', o que motivou uma briga entre as duas, a princípio somente no plano verbal. Alguns dias depois, a 'amante', que segundo a esposa estava embriagada, voltou à casa da família para revidar as agressões verbais. Nesse momento, o assunto já circulava pela vizinhança, chegando também aos ouvidos de algumas lideranças indígenas. As lideranças chamaram apenas as mulheres envolvidas na situação e promoveram uma audiência sobre o caso. Posteriormente, os envolvidos foram chamados para aconselhamento individual: primeiro a 'amante' e depois a esposa e o marido. A princípio, a atitude das lideranças apaziguou os ânimos e fez com que a esposa e a amante começassem a frequentar igrejas crentes.

\section{Outras formas coletivas de autoatenção}

Na TIX também existem outras práticas que não estão associadas a grupos ou ideologias legitimadas. O grupo em si também demonstra estratégias particulares para regular os casos imorais ou excessivos associados à utilização das bebidas alcoólicas.

Como as situações de violência são relatadas como as mais problemáticas envolvendo o consumo de tais substâncias, um episódio marcante diz respeito à trajetória de um jovem indígena da localidade sobre o qual pesavam reclamações de agressões e brigas por toda a comunidade. As lideranças indígenas já o haviam solicitado para aconselhamento diversas vezes, mas ele persistiu envolvendo-se em episódios de espancamento da esposa principalmente. As atitudes subsequentes levaram-no à amarração ao tronco como prevenção, o que também passou a ser frequente. Os atos de violência praticados pelo jovem culminaram com o ataque feroz a outro indígena, o qual teve parte do nariz arrancada por uma mordida. Como de praxe, mais uma vez o tronco foi utilizado imediatamente, contudo, alguns dias depois do ocorrido ele foi encontrado morto na beira de uma das estradas que corta a TIX. 
O caso continuava vivo nos relatos feitos pela população em geral e pelas lideranças, muito embora não indicassem preocupações sérias em relação às circunstâncias ou desdobramentos do falecimento. Algumas pessoas chegaram a concordar que tinha sido melhor assim, pois "o homem incomodava muito após suas farras". Talvez a questão do exílio por transferência não tenha se aplicado ao caso pelo fato de o homem não possuir familiares em outros lugares, como também pode ser que a situação necessitasse uma atitude mais emergencial. A história não teve repercussões sérias, como punição dos responsáveis pela morte, mas continua a ser rememorada quando o assunto das bebidas alcoólicas é levantado.

\section{Considerações finais}

O campo da saúde coletiva brasileira é um setor preocupado com a temática das bebidas alcoólicas e elabora um discurso bastante atual sobre atuação profissional adequada aos contextos culturais diferenciados. Entretanto, na prática, as atuações da Funasa em relação aos povos indígenas ainda esbarram na dificuldade de conciliação das características particulares das populações com problemáticas de ordem epidemiológica geral. Em última instância, o que está em jogo nesses modelos de atenção é o constante questionamento da possibilidade de compatibilidade entre os saberes biomédicos e os saberes indígenas, entre os interesses da sociedade envolvente e os das sociedades indígenas, um questionamento que emerge tanto na formulação e compreensão dos processos contextualizados de saúde e doença, quanto nas práticas aplicadas na solução dos eventuais problemas relacionados, neste caso, ao uso de bebidas alcoólicas.

A revisão das abordagens sobre a temática no Brasil (Landgon, 2001) ${ }^{12}$ reflete a inexistência de consenso sobre a natureza do fenômeno do uso de bebidas alcoólicas pelas populações indígenas brasileiras bem como de efetivas atuações programáticas. No contexto kaingang, isto é motivo para a elaboração de modos particulares de percepção e atuação sobre a presença dessas substâncias na TIX e as eventuais consequências a elas relacionadas. Num sentido analítico amplo, é notável que estes mecanismos demonstram a alta complexidade e a admirável criatividade nas formas locais de organização e autogestão desta população.

Para entender o que é problemático em relação ao uso de bebidas alcoólicas na TIX, é preciso levar em conta a ideia de visibilidade. Se, por um lado, tais substâncias são valorizadas nos eventos festivos, quando são comercializadas e consumidas abertamente; por outro lado, beber sozinho e, principalmente, demonstrar em público que se está alcoolizado em situações cotidianas é algo altamente condenável. Do ponto de vista das trajetórias individuais, os que desejam consumir bebidas alcoólicas no dia a dia são forçados a manterem-se em suas casas ou em locais distantes dos circuitos centrais de circulação nas aldeias. Importa 
frisar que os problemas relacionados ao consumo de bebidas alcoólicas passam por aspectos ligados a deteriorações que afetam a ordem da pessoa Kaingang. A reprovação do uso de bebidas alcoólicas não está tão ligada à quantidade do que se consome, mas à profanação de espaços considerados inapropriados ou da associação do consumo a alguma forma local de violência.

A noção de 'perturbação físico-moral', proposta por Duarte (1994), ajuda a escapar das interpretações biomédicas de funcionamento das patologias e da ênfase sobre a categoria 'doença'. Em contraponto, o autor propõe que a dimensão de moralidade remete à noção de corpo em níveis amplos da construção de emoções e noções de pessoa e à importância dos códigos e regras eminentemente socioculturais. A centralidade da noção de pessoa nas sociedades indígenas brasileiras (Seeger, Da Matta G Viveiros de Castro, 1987) parte da sugestão de Mauss (2003) a respeito da valorização da predominância da vida grupal sobre a individual em algumas sociedades não ocidentais: a pessoa é uma instância eminentemente relacional, constituída e mantida socialmente.

No contexto da TIX é necessário relembrar que nem todo tipo de utilização de bebidas alcoólicas é condenado, mas, da mesma forma, é importante ressaltar que os Kaingang da TIX possuem a categoria bêudo para se referirem aos que cometem excessos. O bêudo, a quem são direcionadas acusações de perturbações físico-morais, passa à condição de outsider, ou desviante (Becker, 2008) - aquele que infringe as regras criadas por grupos e aplicadas particularmente. Essas regras compartilhadas relacionam-se a preceitos normativos para comportamentos e atitudes que fazem sentido nas circunscrições do grupo. Assim, a noção sociológica de 'controle social' (Becker, 2008) ajuda a compreender as moralidades que se impõem com base em expectativas de conduta e sanções predeterminadas no caso de infrações. Práticas de autoatenção (Menéndez, 2009) são empregadas como modos de enfrentamento das situações indesejadas, principalmente aquelas que envolvem algum tipo de violência. Aqui afloram parâmetros ideológicos, contraditórios ou não, que regulam as regras empregadas pelos Kaingang no controle das bebidas alcoólicas e dos outsiders.

O reconhecimento local dos problemas relacionados ao uso de bebidas alcoólicas só faz sentido se situado a partir de uma variedade de pontos de vista reflexivos sobre a presença destas substâncias. Apesar de os próprios bêudos estarem aptos a elencar dificuldades para efetivar o consumo, as questões que mobilizam o grupo dizem respeito à manutenção local das moralidades. Na TIX, algumas atuações não assumidas podem ser adotadas esporadicamente em casos particulares, mas dois grupos que reivindicam legitimação da autoridade sobre o assunto são mais significativos. Por um lado a ideologia 'crente', que atua como uma das vozes mais severas contra a presença das bebidas alcoólicas na TIX e serve como ponto de apoio na manutenção da moralidade centrada nos objetivos 
de abstinência para a consolidação de seguidores. Os momentos críticos de trajetórias individuais figuram como brechas a serem utilizadas na ressignificação das experiências daqueles que desejam aceitar a 'palavra' de Jesus - de forma duradoura ou não. Por outro lado, as lideranças indígenas, que trazem no seu discurso preocupações com as situações representativas dos indígenas como grupo, o que é perceptível pela legitimidade na aplicação de procedimentos punitivos próprios largamente utilizados sobre os que infringem as regras locais. O que passa a estar em jogo é uma discussão sobre o estatuto das bebidas alcoólicas na localidade. Se, para os crentes, elas são maléficas em sua essência e devem ser evitadas; para as lideranças indígenas, elas são ambíguas: é necessário coibir as atitudes indesejadas associadas ao seu consumo; mas, ao mesmo tempo, é necessário valorizar as reivindicações da população acerca da sua oferta nos eventos festivos.

Este texto demonstra a dificuldade de se compreender a natureza dos problemas relacionados ao uso de bebidas alcoólicas. A intenção foi elaborar um olhar diversificado sobre a temática em questão a partir da consideração da multiplicidade de dimensões envolvidas no que chamamos aqui de alcoolização. Não pretendemos, entretanto, esgotá-las na abordagem do contexto da TIX, até porque isso é impossível. Esperamos ter, sim, contribuído com informações sobre uma faceta da sociedade kaingang que emerge de tal discussão.

Notas

1 Este capítulo foi extraído da dissertação elaborada por Ari Ghiggi Junior orientada por Esther Jean Langdon e Flávio Braune Wiik (Ghiggi Jr, 2010). A dissertação faz parte de projeto mais amplo, intitulado Avaliação do modelo de atenção diferenciada aos povos indígenas: os casos Kaingang (Santa Catarina) e Munduruku (Amazonas), apoiado pelo Edital MS/Funasa - MS/ Decit - Opas 2007, processo n. 550 217111057, com parecer favorável do Conselho Nacional de Ética em Pesquisa n. 546/2008.

2 A Funasa incorpora o termo 'alcoolismo' na elaboração do seu discurso sobre a problemática, o que pode ser observado no projeto Vigisus II, subcomponente II, relacionado à saúde mental de povos indígenas (Brasil, 2005).

3 Ver também a Apresentação desta coletânea.

4 Ver também capítulos 4 e 8 deste livro.

5 Disponível em: <www.ibge.gov.br/cidadesat/topwindow.htm?1>. Acesso em abril de 2013.

6 Disponível em: <www.ibge.gov.br/cidadesat/topwindow.htm?1>. Acesso em abril de 2013.

7 Esse croqui representa a distribuição das aldeias, especialmente a Pinhalzinho e a Sede, em relação aos municípios de referência microrregional e aos rios Xapecó e Xapecozinho. 
8 O termo 'tradição' foi usado em alguns trabalhos antropológicos feitos na TIX, como em Oliveira (1996), e refere-se ao conjunto de representações e práticas ligadas ao 'tempo dos antigos' ou 'do mato': o ritual do kiki, os aspectos cosmológicos e de organização social dualista kaingang e os especialistas locais em cura, como xamãs (kuiãs), curandeiros e remedistas.

9 Conforme algumas lideranças religiosas evangélicas, os crentes correspondem a $70 \%$ da população da aldeia Sede.

10 Disponível em: <www.abant.org.br/?code=3.1>. Acesso em: abr. 2013.

11 A lei federal n. 6.001, de dezembro de 1973, dispõe sobre o estatuto do índio. No título IV, das Normas Penais, capítulo II, Dos Crimes Contra os Índios, o artigo 58 enumera o que constitui crimes contra os índios e a cultura indígena. O item III desse artigo, mais especificamente, prevê pena de seis meses a dois anos para quem "propiciar, por qualquer meio, a aquisição, o uso e a disseminação de bebidas alcoólicas, nos grupos tribais ou entre índios não integrados". Os posicionamentos sobre a validade desta lei são altamente controversos, uma vez que a Constituição Federal Brasileira de 1988 deveria tê-la superado. Na prática, como observado na TIX, ela representa uma ferramenta de controle à disposição de juristas locais, que a utilizam em momentos em que a 'proibição' da distribuição de bebidas alcoólicas é estratégica para controle da própria população indígena.

12 Ver também capítulo 1 deste livro.

Referências

ACIOLI, M. D. O Processo de Alcoolização entre os Pankararu: um estudo em etnoepidemiologia, 2002. Tese de Doutorado, Campinas: Instituto de Saúde Coletiva, Unicamp.

ALMEIDA, L. K. Dinâmica Religiosa entre os Kaingang do Posto Indígena Xapecó-SC, 1998. Dissertação de Mestrado, Florianópolis: PPGAS, UFSC.

BECKER, H. S. Outsiders: estudos de sociologia do desvio. Rio de Janeiro: Zahar, 2008.

BRASIL. Ministério da Saúde. Secretaria de Vigilância em Saúde. Projeto Vigisus II Modernização do Sistema Nacional de Vigilância em Saúde, Manual operativo Componente II - Volume 3 - Saúde Indígena. Brasília: Editora do Ministério da Saúde, 2005.

BRASIL. Ministério do Planejamento, Orçamento e Gestão. Instituto Brasileiro de Geografia e Estatística - IBGE. Diretoria de Pesquisas. Os Indígenas no Censo Demográfico: primeiras considerações com base no quesito cor ou raça. Rio de Janeiro, 2012. Relatório. (Mimeo.)

CARDOSO DE OLIVEIRA, R. O mal-estar da ética na antropologia prática. In: VICTORA, C. G. et al. (Orgs.). Antropologia e Ética: o debate atual no Brasil. Niterói: EdUFF, 2004.

DIEHL, E. E. Entendimentos, Práticas e Contextos Sociopolíticos do Uso de Medicamentos entre os Kaingang (Terra Indígena Xapecó, Santa Catarina, Brasil), 2001. Tese de Doutorado, Rio de Janeiro: Fundação Oswaldo Cruz. 
DOUGLAS, M. A distinctive anthropological perspective. In: DOUGLAS, M. (Org.). Constructive Drinking: perspectives on drink from anthropology. Cambridge: Cambridge University Press, 1987.

DUARTE, L. F. D. A outra saúde: mental, psicossocial, físico-moral? In: ALVES, P. C. G MINAYO, M. C. S. (Orgs.). Saúde e Doença: um olhar antropológico. Rio de Janeiro: Editora Fiocruz, 1994.

FERNANDES, R. C. Autoridade Política Kaingang: um estudo sobre a construção da legitimidade política entre os Kaingang de Palmas, 1998. Dissertação de Mestrado, Florianópolis: PPGAS, UFSC.

FIGUEIREDO, V. Issue of Health and Marginality in Northern Brazil, 2000. Dissertação de Mestrado, London: Goldsmith University.

GHIGGI JR., A. Estudo Etnográfico sobre Alcoolização entre os Índios Kaingang da Terra Indígena Xapecó: das dimensões construtivas à perturbação, 2010. Dissertação de Mestrado, Florianópolis: PPGAS, UFSC.

KUNITZ, S. J. G LEVY, J. E. Drinking Careers: a twenty-five-year study of three Navajo populations. New Haven, CT: Yale University Press, 1994.

LANGDON, E. J. O que beber, como beber e quando beber: o contexto sociocultural no alcoolismo entre as populações indígenas. In: SEMINÁRIO SOBRE ALCOOLISMO E DST/AIDS ENTRE OS POVOS INDÍGENAS. Brasília: Ministério da Saúde/Secretaria de Políticas de Saúde/Coordenação Nacional de DST e Aids, 2001.

MANFROI, N. M. S. A História dos Kaingang da Terra Indígena Xapecó (SC) nos Artigos de Antônio Selistre de Campos: Jornal A Voz de Chapecó 1939/1952, 2008. Dissertação de Mestrado, Florianópolis: PPGH, UFSC.

MARCUS, G. Ethnography Through Thick and Thin. New Jersey: Princeton University Press, 1998.

MAUSS, M. Uma categoria do espírito humano: a noção de pessoa, a de eu. In: MAUSS, M. Sociologia e Antropologia, São Paulo: Cosac Naify, 2003.

MELO, J. R. F.; MACIEL, S. C. G NEVES, F. S. Representação social sobre o uso do álcool na população indígena potiguara: um estudo com profissionais de saúde do sexo feminino. In: SEMINÁRIO NACIONAL GÊNERO E PRÁTICAS CULTURAIS: CULTURAS, LEITURAS E REPRESENTAÇÕES, II, out. 2009, João Pessoa.

MENÉNDEZ, E. L. Modelos, saberes e formas de atenção dos padecimentos: exclusões ideológicas e articulações práticas. In: MENÉNDEZ, E. L. Sujeitos, Saberes e Estruturas: uma introdução ao enfoque relacional no estudo da saúde coletiva. São Paulo: Hucitec, 2009

NACKE, A. O Índio e a Terra: a luta pela sobrevivência no P. I. Xapecó - SC, 1983. Dissertação de Mestrado, Florianópolis: PPGCS, UFSC.

NEVES, D. P. Alcoolismo: acusação ou diagnóstico? Cadernos de Saúde Pública, 20(1): 736, 2004.

ORGANIZAÇÃO MUNDIAL DA SAÚDE (OMS). Classificação de Transtornos Mentais e de Comportamento da CID-10. Porto Alegre: Artes Médicas, 1993. 
RAMOS, L. M. M. Vénh Jykré e Ke Ha Han Ke: permanência e mudança do sistema jurídico dos Kaingang no Tibagi, 2008. Tese de Doutorado, Brasília: PPGAS, UNB.

SANTOS, F. S. D. Alcoolismo: algumas reflexões acerca do imaginário de uma doença. Physis: Revista de Saúde Coletiva, 2(3): 75-95, 1993.

SEEGER, A.; DA MATTA, R. G VIVEIROS DE CASTRO, E. A construção da pessoa nas sociedades indígenas brasileiras. In: OLIVEIRA FILHO, J. P. de (Org.). Sociedades Indígenas e Indigenismo no Brasil. Rio de Janeiro: Editora UFRJ, Marco Zero, 1987.

SoUZA, M. L. P. Alcoolização e Violência no Alto Rio Negro, 2004. Dissertação de Mestrado, Manaus: Programa de Pós-Graduação em Sociedade e Cultura na Amazônia da Ufam.

SOUZA, M. L. P. G GARNELO, L. Desconstruindo o alcoolismo: notas a partir da construção do objeto de pesquisa no contexto da saúde indígena. Revista Latinoamericana de Psicopatologia Fundamental, IX(2): 279-292, 2006.

VEIGA, J. As religiões cristãs entre os Kaingang: mudança e permanência. In: WRIGHT, R. M. (Org.). Transformando os Deuses. v. II. Igrejas Evangélicas, Pentecostais e Neopentecostais entre os Povos Indígenas no Brasil. Campinas: Editora Unicamp, 2004. 


\section{Da Prevenção de Doenças à Promoção da Saúde: reflexões a partir da questão do uso de bebidas alcoólicas por indígenas ${ }^{1}$}

As atividades visando à prevenção de doenças estão entre as atribuições mais importantes a serem desempenhadas por profissionais da saúde que atuam na atenção básica, em geral, e na saúde indígena, em particular. Um exemplo clássico dessa modalidade de intervenção é a vacinação contra certas doenças infectocontagiosas, que está associada a impactos importantes na redução da morbimortalidade infantil.

Quando se sai do campo das doenças infecciosas e se busca incorporar as doenças crônico-degenerativas e as relacionadas aos comportamentos humanos, tornam-se evidentes as limitações e as dificuldades das estratégias de prevenção atualmente disponíveis (Czeresnia, 2003; Buss, 2003). O problema se amplia quando as políticas de saúde pretendem induzir mudanças de hábitos, como, por exemplo, prática de atividades físicas, alteração na alimentação, utilização de preservativo, redução ou interrupção do consumo de substâncias psicoativas, ilícitas ou lícitas, como cigarro e álcool.

Informar muitas vezes não é suficiente para mudar o comportamento. Se apenas se prescreve para uma doméstica que trabalha o dia inteiro que ela deve fazer exercícios aeróbicos; para um idoso que mora com a nora e não tem controle sobre o preparo de suas refeições que sua comida deve ter pouco sal; para uma mulher casada e monógama que ela deveria usar preservativo nas relações sexuais com o esposo; ou para um jovem não beber quando for a uma festa, os resultados obtidos com tais recomendações tenderão a ser, no mínimo, limitados (Salles-Costa et al., 2003; Sousa, Espírito Santo G Motta, 2008; Garnelo G Langdon, 2005).

O caminho mais curto, ingênuo e cruel seria responsabilizar as pessoas, acusando-as de não aderir às orientações, como frequentemente ocorre. Outro caminho, não desprovido de desafios, seria buscar reconhecer e incorporar, nas práticas dos serviços de saúde, as concepções populares sobre o processo saúdedoença-cuidado; sobre a insalubridade dos processos de trabalho e das relações de poder que se estabelecem entre diferentes gêneros e grupos etários, bem como a forte inserção e estímulo social de determinados comportamentos. 
No caso da saúde indígena, há uma demanda crescente para que os profissionais da saúde realizem atividades de prevenção fora do escopo das doenças infecciosas. Aí está incluída a questão do uso de álcool e dos agravos a ele relacionados. ${ }^{2} \mathrm{O}$ surgimento dessa demanda pode ser influenciado por diversos fatores, tais como a proliferação de pesquisas nos últimos dez anos (Albuquerque G Souza, 1998; Simonian, 1998; Quiles, 2000; Ferreira, 2001; Oliveira, 2001; Souza, Oliveira G Kohatsu, 2003; Souza, 2004; Souza G Garnelo, 2006, 2007; Souza, Schweickardt G Garnelo, 2007; Souza, Deslandes G Garnelo, 2010); as solicitações feitas pelos próprios indígenas, via seus representantes, nos diferentes fóruns de controle social em saúde, e o aparecimento dos primeiros ensaios para delineamento de uma política nacional de atenção a 'saúde mental' para os povos indígenas (Brasil, 2007).

Profissionais da saúde, mesmo aqueles com pouca experiência de atuação na saúde indígena, mas que buscam observar o cotidiano com um olhar culturalmente sensível, podem constatar, como Langdon (2005: 110), que o uso de bebidas alcoólicas em diferentes grupos é "parte integrante da construção de vínculo social, pois é uma manifestação importante de sociabilidade inter e intragrupal", apesar de também poder se relacionar a diferentes agravos à saúde.

Durante os diversos contatos com profissionais da saúde que trabalham com sociedades indígenas, pude notar diferentes posições a respeito do possível envolvimento desses no desenvolvimento de estratégias para o enfrentamento dos problemas relacionados ao uso do álcool nestes grupos culturalmente diferenciados. Nos extremos dessas posições, identifiquei duas posturas, que didaticamente resumo com expressões construídas a partir de seus discursos: "isso não tem nada a ver com a gente da saúde", ou "isso é muito complicado, fazer tudo sozinho fica muito difícil".

Em relação à primeira postura, ressalte-se sua fragmentária compreensão da dinâmica saúde-doença-cuidado, redundando em uma estreita visão do papel dos profissionais da saúde diante de situações desafiadoras e em uma falta de compromisso com abordagens integrais da saúde. Já o segundo posicionamento evidencia o reconhecimento da complexidade da questão em pauta e das limitações das estratégias usualmente adotadas pelo setor saúde, além de apontar para a necessidade de articulação com outros setores e atores sociais.

Pode-se, portanto, construir uma associação entre as ideias daqueles que se alinham à segunda posição e as ações chamadas em saúde coletiva de 'promoção da saúde'. A proposta deste capítulo é evidenciar as diferenças entre as ações de prevenção de doenças e as de promoção da saúde, tomando como fio condutor a questão do uso de álcool por povos indígenas. Pretende-se, ainda, demarcar a dificuldade de adequação cultural, no contexto indígena, das estratégias de prevenção tidas como efetivas no contexto urbano, bem como explorar as 
possibilidades de adequação das estratégias de promoção da saúde ao contexto ameríndio.

Para tanto, este trabalho está dividido em duas etapas. Na primeira, apresentam-se as principais características das ações de prevenção de doenças, estabelecendo-se um diálogo entre as construções conceituais de Czeresnia (2003) e Buss (2003) e as propostas norteadoras sintetizadas por Laranjeira e Romano (2004) e Duailibi e Laranjeira (2007), ${ }^{3}$ para o estabelecimento de políticas públicas para prevenção de agravos à saúde relacionados ao uso de bebidas alcoólicas.

Ao mesmo tempo, será feita uma análise da adaptabilidade de parte dessas propostas ao contexto indígena, partindo, sobretudo, da experiência de pesquisa sobre o uso de bebidas alcoólicas desenvolvida entre povos indígenas do Alto Rio Negro, Noroeste Amazônico (Souza, 2004, 2005, 2007; Souza G Garnelo, 2006, 2007; Souza, Schweickardt G Garnelo, 2007; Souza, Deslandes G Garnelo, 2010). ${ }^{4}$

Na segunda etapa, retornando à Czeresnia (2003) e Buss (2003), discutirse-ão as características das ações de promoção da saúde, estabelecendo-se um diálogo com as propostas apresentadas por Langdon $(2005)^{5}$ para lidar com a questão do uso de álcool entre populações indígenas.

\section{Prevenção: evitando doença}

O verbo prevenir associa-se às ideias de "preparar, chegar antes de, dispor de maneira que evite (dano, mal); impedir que se realize" (Ferreira apud Czeresnia, 2003: 45). No caso da saúde, a preocupação é evitar as diferentes doenças. As ações de prevenção se orientam, portanto, para o "controle e enfraquecimento dos fatores de risco ou fatores causais de grupos de enfermidades ou de uma enfermidade específica; seu foco é a doença" (Buss, 2003: 33).

Subjacente a essas afirmativas aparentemente simples, há uma série de pressupostos que precisam ser explicitados. Neste tipo de abordagem, parte-se de um entendimento de que para cada doença ou agravo a ser prevenido haveria um conjunto de conhecimentos, suficientemente sólidos, embasados no saber científico hegemônico, capaz de subsidiar as ações de prevenção (Czeresnia, 2003). Nesse sentido, Laranjeira e Romano, ao apresentarem o potencial objetivo das políticas públicas voltadas para o problema do abuso de álcool, entendem que este visaria a "poupar-lhes [aos formuladores de políticas públicas] o trabalho de 'reinventar a roda', já que o estado atual da pesquisa científica torna possível saber quais medidas são eficazes e quais não o são, possibilitando ainda, dessa forma, a aplicação do dinheiro público em políticas de resultado comprovado" (Laranjeira G Romano, 2004: 69).

Ações preventivas específicas serão consideradas eficazes na medida em que se demonstre cientificamente sua capacidade de evitar o surgimento de doenças/ 
agravos específicos. As ações preventivas em relação à questão do álcool seriam consideradas efetivas quando fossem capazes de reduzir os danos relacionados ao seu consumo e limitar o acesso da população a esta substância (Duailibi G Laranjeira, 2007). Assim, trabalha-se com uma noção de saúde como 'não doença', desprovida de especificidade e positividade. A ausência de doenças seria um objetivo suficiente para as ações de prevenção (Buss, 2003).

Um aspecto a ser destacado é que na prevenção de agravos à saúde relacionados ao uso de álcool tem-se como intento principal evitar a intoxicação alcoólica aguda, e não a dependência ao álcool, pois "o risco de problemas decorrentes de um único episódio de intoxicação é mais alto entre aqueles que o fazem infrequentemente do que entre aqueles que bebem com mais frequência" (Duailibi G Laranjeira, 2007: 841). Isso vai contra o senso comum de associar os problemas relacionados ao consumo de álcool com a dependência. Assim, a estratégia preventiva por excelência seria aquela que diminuísse as chances de as pessoas fazerem uso de álcool, condição sine qua non para a intoxicação.

Segundo as propostas de Laranjeira e Romano (2004) e de Duailibi e Laranjeira (2007), apenas as estratégias que limitassem a disponibilidade do álcool seriam consideradas realmente efetivas. ${ }^{6}$ Para os autores, essa disponibilidade seria influenciada por três fatores principais: o econômico (preço), a facilidade de compra e venda (varejo) e a acessibilidade a fontes como a família e os amigos, que expressam a disponibilidade social da bebida. As estratégias de controle da disponibilidade poderiam ser colocadas em prática por meio de políticas públicas regulatórias. Estas medidas seriam direcionadas principalmente para os dois primeiros fatores, que acabariam impactando indiretamente sobre o terceiro fator, cuja regulação seria quase impossível por meio de políticas públicas.

O aumento do preço das bebidas alcoólicas seria eficaz ao diminuir as chances de consumo, sobretudo entre aqueles com menor poder aquisitivo, como os mais jovens e os com graves problemas de dependência. Considerando a questão do varejo, há um conjunto de ações que, de acordo com os autores, seriam eficazes, tais como: delimitação da localização dos pontos de venda (proibição do comércio de bebidas alcoólicas em locais próximos a escolas ou em eventos com grande aglomeração de pessoas); diminuição da densidade dos pontos de venda (o que, pela lei da oferta e procura, tenderia a fazer com que os preços aumentassem); estabelecimento de idade mínima para a compra de bebidas; restrição dos dias e horários de venda (não comercializando álcool após determinada hora, como adotado em algumas cidades); instituição de serviços responsáveis de venda de bebidas (treinamento para não servir pessoas alcoolizadas, com responsabilização legal para quem o fizesse).

Pode-se observar que todas essas medidas têm em comum a necessidade de fiscalização e punição dos que infringem essas regulamentações ou, nas palavras 
dos próprios autores, "o que funciona realmente é a certeza de que uma determinada infração será punida" (Duailibi G Laranjeira, 2007: 846). Dessa forma, a adesão das pessoas não passaria necessariamente por um ato de escolha, podendo ser consequência exclusivamente do poder coercitivo da lei e dos aparatos de repressão.

O Estatuto do Índio (Brasil, 1973), que pode ser considerado um marco regulatório para a questão do uso de álcool por indígenas, define em seu artigo 58, inciso $3^{\circ}$, crime contra os índios e a cultura indígena - com pena de seis meses a dois anos de detenção - "propiciar, por qualquer meio, a aquisição, o uso e a disseminação de bebidas alcoólicas, nos grupos tribais ou entre índios não integrados".

As limitações desse instrumento legal são de várias ordens. Há implícito no texto que tal restrição estaria relacionada apenas às populações que residem em terra indígena. Entretanto, não são todos os grupos que vivem nessa situação. Há aqueles cujas terras não estão demarcadas, bem como outros que vivem nas periferias de grandes e pequenas cidades, uma população que tende a crescer, dada a tendência de urbanização da população indígena brasileira (Coimbra Jr. G Santos, 2000). Assim, medidas de prevenção baseadas nas recomendações desse dispositivo legal não impactariam na totalidade dos povos indígenas nacionais.

Além disso é evidentemente fraca a capacidade do Estado brasileiro em fiscalizar a introdução de bebidas alcoólicas nas terras indígenas, se considerarmos as grandes dimensões territoriais do país e a escassez de recursos de pessoal e financeiros para essa finalidade (Souza, 2004). Paralelamente, por ser uma lei de caráter repressivo, favorece o desenvolvimento de um rendoso mercado negro de venda de bebidas alcoólicas, considerando os preços exorbitantes observados em determinadas regiões indígenas. Por exemplo, enquanto na sede municipal de São Gabriel da Cachoeira, no Alto Rio Negro um litro de cachaça custa três reais, no interior das terras indígenas seu preço pode chegar a cinquenta. Destaca-se que, pelo menos nesta região ou em partes dela, há uma crescente monetarização da vida cotidiana. Assim, o comércio de bebidas alcoólicas, mesmo de caráter eventual, tornase uma alternativa para auferir lucro, inclusive entre os indígenas (Souza, Deslandes G Garnelo, 2010). Por fim, é importante ressaltar que esse dispositivo legal não goza de popularidade mesmo entre lideranças indígenas, principalmente porque costuma ser associado ao regime tutelar, historicamente adotado pelo Estado brasileiro, considerado anacrônico por atribuir ao índio a condição de juridicamente incapaz.

A possibilidade de êxito dessas medidas preventivas é maior em contextos urbanos, como na sede municipal de São Gabriel da Cachoeira, em que existe algum aparato estatal. Pode-se dizer, sem sombra de dúvida, que em São Gabriel há a necessidade de se implantar medidas regulatórias e de fiscalização da circulação de bebidas alcoólicas. Medidas que coibissem o uso da cachaça como forma de pagamento para trabalhadores indígenas braçais, que proibissem a venda disseminada de bebidas 
alcoólicas nos diversos estabelecimentos comerciais, inclusive nos que não têm autorização legal para fazê-lo, e que reduzissem a oferta acintosa de álcool de farmácia como se fora bebida para consumo humano contribuiriam positivamente para controlar o uso abusivo de álcool (Souza, 2005, 2007).

Entretanto, as estratégias de regulação se mostram de difícil aplicação no interior das terras indígenas. O primeiro ponto a se destacar é, como bem demonstra a literatura, que nas sociedades indígenas das terras baixas sul-americanas não existe a concentração do poder nas mãos das chefias, nem algo que se assemelhe aos atributos coercitivos do Estado (Clastres, 1974). Nas aldeias, as lideranças indígenas trabalham, sobretudo, com o exemplo pessoal e a árdua busca de consensos provisórios, capazes de circunscrever conflitos e conduzir as interações cotidianas nas comunidades. Assim, definir explicitamente o que outras pessoas podem ou não fazer e exercer um controle direto sobre seus atos não faz muito sentido no contexto indígena.

Ainda que essas propostas busquem, sobretudo, regular a venda de bebidas alcoólicas, em contexto indígena, a chamada 'disponibilidade social' de bebida é tema de suma importância nos processos de alcoolização. A observação da localidade de Iauaretê, no Alto Rio Negro, onde, apesar da proibição oficial, há venda de bebidas, tanto industrializadas quanto tradicionais, demonstra que, embora ali um importante processo de urbanização esteja em curso (Andrello, 2006), mecanismos redistributivos que envolvem prestígio entre as famílias indígenas promovem a circulação de bebidas alcoólicas independente de haver transação em dinheiro (Souza G Garnelo, 2007). A importância do contexto social, aliada à sua difícil regulação são elementos ilustrativos da dificuldade de obter o controle do álcool com medidas de proibição e controle da oferta de bebida.

Em Iauaretê, e possivelmente em outros contextos indígenas, de fato a disponibilidade social ganha maior relevo do que a venda no varejo (Souza, Deslandes G Garnelo, 2010). Essa localidade encontra-se subdividida em diferentes vilas, cada uma com suas lideranças e com suas festas nas quais as bebidas alcoólicas são consumidas coletivamente. Tais eventos representam, dentre outros aspectos, a busca pela manutenção de diferenciações entre as vilas e os grupos familiares que ali habitam. Isso costuma gerar a realização de festas simultâneas em várias vilas, cada qual buscando manter sua especificidade em relação às outras (Souza, Deslandes G Garnelo, 2010). Portanto, sugerir um rodízio de festas entre as vilas, para reduzir as oportunidades de consumo de álcool (restrição dos locais de consumo e diminuição de sua densidade), feriria os ideais de autonomia e independência pelos quais os povos indígenas buscam reger suas relações políticas (Clastres, 2004). Implicaria também desconsiderar o fato de que o consumo coletivo de bebidas alcoólicas, nesse contexto, serve para reforçar os laços de solidariedade e auxiliar no gerenciamento de conflitos (Lasmar, 2005). 
Já o estabelecimento de idade mínima para o consumo seria algo igualmente complexo, principalmente se considerarmos que, nesses contextos, critérios cronobiológicos não são os de maior importância para delimitar a fase da vida em que se encontra um indivíduo (Amit-Talai G Wulff, 1995). Por exemplo, no Alto Rio Negro, o consumo de bebidas tradicionais fermentadas com maior teor alcoólico deveria ocorrer após os rituais de iniciação masculina, que demarcavam a passagem da infância para idade adulta (Hugh-Jones, 1979). Porém esses rituais, por diferentes motivos, entraram em desuso em diversas partes da região (Lasmar, 2005; Andrello, 2006). O fato, associado à introdução da escolaridade formal, vem borrando progressivamente esse limite, havendo, hoje, uma indefinição quanto ao momento em que alguém poderia começar a consumir bebidas alcoólicas. Cabe lembrar que nestas sociedades indígenas, negar bebida a um jovem (ou a outra pessoa) pode gerar acusação de sovinice; por outro lado, recusar uma bebida ofertada, pode conotar um receio velado de que ela poderia estar 'estragada' (envenenada). Essas atitudes são consideradas socialmente reprováveis, passíveis, inclusive, de retaliação xamânica (Souza, Deslandes G Garnelo, 2010).

Como noutros contextos indígenas, em Iauaretê, o consumo de bebidas alcoólicas é regulado principalmente pela quantidade de bebida produzida (e/ou adquirida) para cada ocasião de consumo, sendo infrequente a prática de estocagem (Kunitz G Levy, 1994; Souza G Garnelo, 2007). Uma alternativa para inibir o consumo excessivo seria então limitar a quantidade de bebida preparada; porém, ali, o prestígio de uma liderança é, não raro, medido pela capacidade de mobilizar seu grupo para desenvolver trabalhos coletivos, tal como ocorre na produção de bebidas fermentadas tradicionais (caxiri) para as festas (Jackson, 1983; Chernela, 1993). Uma grande quantidade de caxiri disponível para uma festa evidencia a capacidade de liderança do chefe indígena. Além disso, sendo o caxiri fruto do labor da mulher, produzir a bebida em grande quantidade também é um indicativo do zelo para com sua roça de mandioca e a produção de derivados da mesma. Ele igualmente representa um elemento importante para uma autoimagem feminina positiva (Lasmar, 2005). Nesse caso, limitar a produção de caxiri traria importante implicação negativa na harmonia das relações sociopolíticas nessa sociedade.

\section{Promoção: construindo saúde}

Promover "tem o significado de dar impulso a, fomentar, originar, gerar" (Ferreira apud Czeresnia, 2003: 45). Aqui se trata de promover saúde. Não se deve conceber a saúde exclusivamente como a ausência de doença, mas sim como algo dotado de positividade, e que se relaciona a valores como "solidariedade, equidade, democracia, cidadania, desenvolvimento, participação, parceria, entre outros" (Buss, 2003: 16). As estratégias de promoção não visam exclusivamente a evitar doenças 
específicas, mas sim contribuir para "a transformação das condições de vida e de trabalho que confortam a estrutura subjacente aos problemas de saúde" (Czeresnia, 2003: 45).

Partindo desses enunciados iniciais, é possível observar, nas ações de promoção da saúde, a busca de incorporar o reconhecimento da complexidade do processo saúde-doença. Langdon (2005), após uma revisão da literatura internacional e nacional sobre o uso de álcool por indígenas, apresentou um conjunto de princípios que deveriam pautar as iniciativas para lidar com esta questão. Ainda que a autora não tenha avançado nessa direção, os princípios que enunciou são congruentes com as estratégias de promoção da saúde, e serão aqui utilizados para compor a argumentação utilizada para aprofundar a discussão.

Um primeiro princípio seria evitar o uso da categoria alcoolismo. A principal objeção da autora para o uso dessa categoria se associa ao fato de remeter a uma classificação estritamente biomédica, associando-se à ideia de um evento restrito a um indivíduo, com apresentação e etiologia universais, independentemente do contexto em que o problema ocorra. Souza e Garnelo (2006) lembram inclusive que o termo alcoolismo, além de estigmatizador, é impreciso do ponto de vista biomédico, não constando sequer nos atuais códigos de classificação de doenças.

Um aspecto importante na discussão de Langdon (2005) é que tanto a anacrônica categoria alcoolismo, como quaisquer outras categorias biomédicas contemporâneas relacionadas ao uso do álcool, não seriam suficientemente maleáveis para incorporar as especificidades socioculturais relacionadas aos modos de beber, e ao que seja considerado consumo normal de álcool, que é infinitamente variável, segundo o contexto e o momento histórico (Oyacer G Ñanco, 1998).

Em síntese, em contextos indígenas seria de fundamental importância compreender quando o modo de beber passa a ser considerado algo socialmente problemático. ${ }^{7}$ Tais proposições vão ao encontro das formulações de Buss (2003), quando ele menciona que um dos avanços das estratégias de promoção da saúde seria ir além das dimensões biomédicas de doença, e que no trabalho de promoção da saúde seria importante incorporar o "mal-estar como percepção subjetiva, relacionada ou não com a enfermidade, aos (...) objetos de planejamento/ intervenção" (Buss, 2003: 34).

Assim, para compreender quando o beber se torna um problema em determinado contexto, seria de fundamental importância buscar apreender as características singulares do contexto no qual se faz uso de bebidas alcoólicas; tal empreendimento é congruente com o segundo princípio identificado por Langdon (2005). A apreensão das singularidades locais permitirá também que se possam, em cenários específicos, identificar como as condições de vida contemporâneas influenciam os diversos modos de beber em diferentes povos indígenas (Souza, 
Deslandes G Garnelo, 2010). Em que pese a grande diversidade das condições de vida dos vários grupos indígenas no Brasil, a revisão da literatura realizada por Langdon (2005: 116-117) também aponta a necessidade de se reconhecer a influência "da violência, das mudanças e dos obstáculos trazidos pelo contato [interétnico, com a sociedade nacional], que dificulta que eles pratiquem seu modo de vida e tenham uma vida saudável", algo que representa pontos comuns entre esses modos de vida e que, certamente, influencia nos seus modos de beber.

Assim, estratégias a serem utilizadas para lidar com o uso problemático de álcool por indígenas deveriam não só reconhecer sua influência, mas também buscar intervir nesses aspectos do contato interétnico. Tais estratégias alinhamse, assim, àquelas da promoção da saúde, pois ambas buscariam "identificar os macrodeterminantes do processo saúde-doença, e transformá-los favoravelmente na direção da saúde", ou seja, "modificar condições de vida, para que sejam dignas e adequadas" (Buss, 2003: 33).

Um terceiro princípio identificado por Langdon (2005) seria buscar envolver a comunidade na qual se pretende intervir em todas as etapas das ações. Para se identificar quando beber se torna um problema, e para apreender o contexto no qual se bebe, seria necessário o estabelecimento de imprescindíveis relações dialógicas com os indígenas. Além desses aspectos, as estratégias de enfrentamento do problema devem ser construídas juntamente com estas populações. Segundo Langdon (2005: 119), "o mais importante é a necessidade de se trabalhar junto com as sociedades envolvidas, indagando a seus membros o significado das bebidas alcoólicas na tradição cultural e no momento atual, e buscando entender quais são suas preocupações e as possíveis respostas aos problemas".

Destaque-se que a "valorização do 'conhecimento popular' e da participação social está na base da formulação conceitual da promoção da saúde" (Buss, 2003: 16). No caso em questão, o saber nativo/popular não é representando como um amontoado de crendices equivocadas sobre o processo saúde-doença que necessitaria ser modificado pela ação sanitária. Aqui, esse conhecimento é entendido como um ponto de partida para a construção pactuada de possíveis estratégias de intervenção capazes de valorizar o ponto de vista indígena sobre o encaminhamento de seus problemas de saúde, que sejam culturalmente sensíveis e menos etnocêntricas.

A valorização do conhecimento nativo não significa, entretanto, que, por si só, seja suficiente para o delineamento e a sustentabilidade das ações de promoção da saúde. Um dos pontos centrais na busca de sucesso para promover a saúde, seria estimular a capacidade dos grupos sociais de traçarem seus próprios caminhos.

A ideia de promoção envolve a de fortalecimento da capacidade individual e coletiva para lidar com a multiplicidade de condicionantes da saúde. (...) Essa concepção 
diz respeito ao fortalecimento da saúde por meio da construção de capacidade de escolha, bem como à utilização do conhecimento com o discernimento de atentar para diferenças e singularidades dos acontecimentos. (Czeresnia, 2003: 47-48)

Assim, o acesso a diversas fontes de conhecimento, o estabelecimento de interações produtivas com outros grupos da sociedade civil, ou a criação de espaços políticos para construção e negociação de estratégias coletivas para lidar com as questões que afligem a sociedade fazem parte do preceito de participação nas políticas de promoção à saúde. Nesse caso, participação é parte intrínseca do processo de empoderamento dos agentes políticos vinculados à promoção da saúde, algo essencial para a sustentabilidade das ações a serem propostas.

No último princípio identificado por Langdon, a autora propõe que, para lidar com os problemas relacionados ao uso de álcool por indígenas, não se deveria focalizar exclusivamente nas questões diretamente relacionadas ao uso de bebidas alcoólicas. Para Langdon (2005: 119) as ações deveriam

ser orientadas para a construção de uma sobrevivência saudável e uma identidade positiva, e não somente às atividades diretamente orientadas à questão do alcoolismo como doença. Se o alcoolismo é o resultado de vários fatores ligados indiretamente a este comportamento, as soluções para a sua prevenção terão necessariamente que procurar lidar com estes fatores.

Vale também destacar que, dentro de uma perspectiva indígena, o conceito de saúde é necessariamente ampliado, e

envolve o acesso pleno aos serviços de saúde, à educação e ao direito de manutenção da vida, implicando na necessidade de garantir que, com todas as mudanças socioeconômicas, o índio possa contar com maneiras de sobrevivência que lhe permitam sair da posição marginal em que se encontra na sociedade brasileira. (Langdon, 2005: 117)

Esse princípio alinha-se claramente à proposta da promoção da saúde, na qual se entende que para "problemas com multideterminações são propostas respostas com múltiplas estratégias, medidas e atores" (Buss, 2003: 16).

\section{Reinventar a roda?}

Espera-se que, com a discussão apresentada, tenha sido possível apreender algumas diferenças que existem entre as ações de prevenção de doenças e de promoção da saúde. Cada uma delas se pauta por premissas teóricas distintas. Um aspecto que parece fornecer um importante substrato para a compreensão das diferenças é a relação que cada uma dessas iniciativas guarda com a complexidade 
dos problemas de saúde. Conforme Czeresnia (2003: 48), "o que diferencia promoção de prevenção é justamente a consciência de que a incerteza do conhecimento científico não é simples limitação técnica passível de sucessivas superações".

Ou seja, partindo-se dos conceitos relacionados à promoção da saúde haverá sempre algo de inatingível para o conhecimento científico, mesmo que se realizem pesquisas e mais pesquisas. De fato, nunca teremos a clareza, por exemplo, do que leva as pessoas a modificarem seus comportamentos, pois se entende que "transformações de comportamento são orientadas simultaneamente por aquilo que se conhece acerca dos determinismos e pela clareza de que não se conhece, nem se chegará a conhecer todos eles" (Czeresnia, 2003: 49).

Neste trabalho, utilizou-se um complexo problema de saúde, que não pode ser facilmente considerado como uma doença do ponto de vista biomédico, como fio condutor para discussão das diferenças entre ações de prevenção de doenças e promoção da saúde. A questão do uso do álcool é intrinsecamente associada ao comportamento social, que é produto de culturas específicas, gerando diferenciações no cenário de eventos que não podem ser simplesmente reduzidas às dimensões biológicas do fenômeno.

Além disso, os problemas relacionados ao uso de bebidas alcoólicas por populações indígenas não representam o único desafio complexo que necessita ser abordado pelo setor saúde na perspectiva totalizante da promoção à saúde. Pensemos nas doenças sexualmente transmissíveis, na desnutrição infantil e na emergência de doenças crônico-degenerativas, apenas para citar algumas situações emblemáticas do próprio contexto da saúde indígena.

Desafios como esses colocam em xeque um conjunto de saberes acumulados. Aquilo que se mostra eficaz num contexto pode se revelar insatisfatório em outro. No caso específico da atenção a saúde indígena, cujo modelo assistencial está sendo construído, faz-se necessário um constante questionamento a respeito da adaptabilidade cultural, ética e sanitária de determinadas intervenções. É bem verdade que se deve, na medida do possível, 'evitar reiventar a roda' (Laranjeira $G$ Romano, 2004). Porém, o que se quer advertir aqui é que talvez seja necessário perguntar se a roda existente é adequada ao contexto em que deverá ser usada. Uma resposta, mesmo que provisória, para essa indagação deve ser buscada por meio do estabelecimento de relações dialógicas com as pessoas com as quais se pretende atuar, reconhecendo-as como sujeitos autônomos e capazes de construir, mediante parceria, alternativas para abordar os problemas que as afligem. 
1 Este capítulo é uma versão ligeiramente modificada de: Souza, M. L. P. G Garnelo, L. Da prevenção de doenças à promoção da saúde: reflexões a partir da questão do uso de bebidas alcoólicas por populações indígenas. In: Garnelo, L. G Pontes, A. L. (Orgs.). Saúde Indígena: uma introdução ao tema. Brasília: MEC/Secadi, 2012. Texto republicado com autorização dos autores e dos editores.

2 Fui convidado em agosto de 2009 a realizar cursos de capacitação em prevenção do alcoolismo em aldeias indígenas, pela coordenação local da Fundação Nacional de Saúde (Funasa), no estado do Amazonas. Somente após o convite, pude perceber que, apesar de investigar a questão do uso de álcool por indígenas há mais de oito anos, não tinha feito nenhuma reflexão mais consistente sobre possíveis estratégias a serem utilizadas para lidar com o problema. Aproveito a oportunidade para agradecer a essa coordenação o desafio, cujo primeiro produto é este trabalho.

3 Os trabalhos de Laranjeira e Romano (2004) e Duailibi e Laranjeira (2007) foram tomados como base para discussão, em virtude de terem sido construídos com de consenso de especialistas e de revisão sistemática da literatura, respectivamente, sendo representativos do pensamento científico hegemônico a respeito das questões em discussão.

4 Ver também capítulos 4 e 5 deste livro.

5 O texto escolhido, além de sintetizar a escassa literatura nacional sobre o tema, explicita os principais pontos de vista da autora sobre a questão do uso de álcool por indígenas. Foi, portanto, selecionado por representar um ponto de vista contra-hegemônico em relação ao conhecimento biomédico estabelecido.

6 Os autores também identificam outras duas grandes modalidades de estratégias preventivas: as intervenções comunitárias/ambientais e as educativas/de persuasão. Entretanto, defendem a ideia de que seus impactos, no consumo e na prevenção de agravos, seriam limitados e que teriam custos elevados, em comparação com as medidas de controle da disponibilidade. Aqui vou-me restringir às estratégias consideradas efetivas pelos autores.

7 Demarca-se que a importância desse aspecto já havia sido demonstrada por Kunitz e Levy (1994), tendo sido por nós ratificado mais recentemente (Souza G Garnelo, 2006). Em outro trabalho (Souza, Schweickardt G Garnelo, 2007) também demonstramos a fragilidade do uso da categoria dependência ao álcool, em certos contextos indígenas. 


\section{Referências}

ALBUQUERQUE, J. I. A. G SOUZA, J. L. Prevalência do alcoolismo na população indígena da Nação Terena do Complexo Sidrolândia Colônia dos Irmãos do Buruti. In: OFICINA MACRORREGIONAL DE ESTRATÉGIA, PREVENÇÃO E CONTROLE DAS DST/AIDS PARA AS POPULAÇÕES INDÍGENAS DAS REGIÕES SUL E SUDESTE, MATO GROSSO DO SUL, 1, 1998, Londrina. Anais... Londrina: Coordenação Nacional de DST/Aids/Programa Municipal para DST, 1998.

AMIT-TALAI, V. G WULFF, H. Youth Cultures: a cross-cultural perspective. London: Routledge, 1995.

ANDRELLO, G. Cidade do Índio: transformações e cotidiano em Iauaretê. São Paulo: Unesp/ ISA, 2006.

BRASIL. Lei n. 6.001, 19 dez. 1973. Dispõe sobre o Estatuto do Índio. Diário Oficial, Brasília, 1973.

BRASIL. Ministério da Saúde. Portaria n. 2.759, 25 out. 2007. Estabelece diretrizes gerais para a Política de Atenção Integral à Saúde Mental das Populações Indígenas e cria o Comitê Gestor. Diário Oficial, Brasília, 2007.

BUSS, P. M. Uma introdução ao conceito de promoção à saúde. In: CZERESNIA, D. G FREITAS, C. M. (Orgs.). Promoção da Saúde: conceitos, reflexões e tendências. Rio de Janeiro: Editora Fiocruz, 2003.

CHERNELA, J. M. The Wanano Indians of the Brazilian Amazon: a sense of space. Austin: University of Texas Press, 1993.

CLASTRES, P. A Sociedade contra o Estado. 2. ed. Rio de Janeiro: Francisco Alves, 1974.

CLASTRES, P. Arqueologia da Violência: a guerra nas sociedades primitivas. São Paulo: Cosac Naify, 2004.

CZERESNIA, D. O conceito de saúde e a diferença entre prevenção e promoção. In: CZERESNIA, D. G FREITAS, C. M. (Orgs.). Promoção da Saúde: conceitos, reflexões e tendências. Rio de Janeiro: Editora Fiocruz, 2003.

COIMBRA JR., C. E. A. G SANTOS, R. V. Saúde, minorias e desigualdade: algumas teias de inter-relações, com ênfase nos povos indígenas no Brasil. Ciência G Saúde Coletiva, 5(1): 125-132, 2000.

DUAILIBI, S. G LARANJEIRA, R. Políticas públicas relacionadas às bebidas alcoólicas. Revista de Saúde Pública, 41(5): 839-848, 2007.

FERREIRA, L. O. Relatório Etnográfico: I Reunião Geral dos karaís, caciques e representantes Mbyá-Guarani no Rio Grande do Sul sobre o uso abusivo de bebidas alcoólicas e alcoolismo. Porto Alegre: Universidade Federal do Rio Grande do Sul, 2001.

GARNELO, L. G LANGDON, J. A antropologia e a reformulação das práticas sanitárias na atenção básica à saúde. In: MINAYO, M. C. S. G COIMBRA JR., C. E. A. (Orgs.). Críticas e Atuantes: ciências sociais e humanas em saúde na América Latina. Rio de Janeiro: Editora Fiocruz, 2005. 
HUGH-JONES, S. The Palm and the Pleiades: initiation and cosmology in Northwest Amazonia. Cambridge: Cambridge University Press, 1979.

JACKSON, J. E. The Fish People: linguistic exomamy and tukanoan identity in Northwest Amazon. Cambridge: Cambridge University Press, 1983.

KUNITZ, S. J. G LEVY, J. E. Drinking Careers: a twenty-five-year study of three Navajo populations. New Haven, London: Yale University Press, 1994.

LANGDON, E. J. O abuso de álcool entre os povos indígenas no Brasil: uma avaliação comparativa. Tellus, 5(8/9): 103-124, 2005.

LARANJEIRA, R. G ROMANO, M. Consenso brasileiro sobre políticas públicas do álcool. Revista Brasileira de Psiquiatria, 26(supl. I): 68-77, 2004.

LASMAR, C. De Volta ao Lago de Leite: gênero e transformação no Alto Rio Negro. São Paulo, Rio de Janeiro: Editora Unesp/ISA, Nuti, 2005.

OLIVEIRA, M. Alcoolismo entre os Kaingang: do sagrado e lúdico à dependência. In: SEMINÁRIO SOBRE ALCOOLISMO E DST/AIDS ENTRE OS POVOS INDÍGENAS. Brasília: Ministério da Saúde/Secretaria de Políticas de Saúde/Coordenação Nacional de DST e AIDS, 2001.

OYACER, A. M. G ÑANCO, J. Alcoholismo y etnía: críticas y propuestas. In: SALGADO, M. S. G MELLA, I. J. (Orgs.). Salud, Cultura y Territorio: bases para una epidemiología intercultural. Lincanray: Ministerio de Salud Chile, 1998.

QUILES, M. Mansidão de Fogo: um estudo etnopsicológico do comportamento alcoólico entre os índios Bororo de Meruri, Mato Grosso, 2000. Dissertação de Mestrado, Cuiába (MT): Universidade Federal de Mato Grosso, 2000.

SALLES-COSTA, R. et al. Associação entre fatores sócio-demográficos e prática de atividade física de lazer no Estudo Pró-Saúde. Cadernos de Saúde Pública, 19(4): 1.095-1.105, 2003.

SIMONIAN, L. T. L. Alcoolismo entre indígenas: abordagens, contextos e perspectivas. In: OFICINA MACRORREGIONAL DE ESTRATÉGIA, PREVENÇÃO E CONTROLE DAS DST/ AIDS PARA AS POPULAÇÕES INDÍGENAS DAS REGIÕES SUL E SUDESTE, MATO GROSSO DO SUL, 1, 1998, Londrina. Anais... Londrina: Coordenação Nacional de DST/ Aids/Programa Municipal para DST, 1998.

SOUSA, M. C. P.; ESPÍRITO SANTO, A. C. G. G MOTTA, S. K. A. Gênero, vulnerabilidade das mulheres ao HIV/Aids e ações de prevenção em bairro da periferia de Teresina, Piauí, Brasil. Saúde G Sociedade, 17(2): 58-68, 2008.

SOUZA, J. A.; OLIVEIRA, M. G KOHATSU, M. O uso de bebidas alcoólicas nas sociedades indígenas: algumas reflexões sobre os Kaingang da bacia do rio Tibagi, Paraná. In: COIMBRA JR., C. E. A.; SANTOS, R. V. G ESCOBAR, A. L. (Orgs.). Epidemiologia e Saúde dos Povos Indígenas no Brasil. Rio de Janeiro: Editora Fiocruz/Abrasco, 2003.

SOUZA, M. L. P. Alcoolização e Violência no Alto Rio Negro, 2004. Dissertação de Mestrado, Manaus (AM): Universidade Federal do Amazonas.

SOUZA, M. L. P. Vulnerabilidade a dependência ao álcool em paciente indígena: relato de caso. Psychiatry on Line Brasil, 10, 2005. Disponível em: <www.polbr.med.br/ano05/ art0105a.php>. Acesso em: jun. 2011 
SOUZA, M. L. P. Comércio de "álcool de farmácia" no município de São Gabriel da Cachoeira, Amazonas, Brasil: uma questão de saúde pública. Revista Brasileira de Psiquiatria, 29(4): 384-384, 2007.

SOUZA, M. L. P. G GARNELO, L. Desconstruindo o alcoolismo: notas a partir da construção do objeto de pesquisa no contexto da saúde indígena. Revista Latinoamericana de Psicopatologia Fundamental, IX(2): 279-292, 2006.

SOUZA, M. L. P. G GARNELO, L. Quando, como e o que se bebe: o processo de alcoolização entre populações indígenas do Alto Rio Negro, Brasil. Cadernos de Saúde Pública, 23(7): 1.640-1.648, 2007.

SOUZA, M. L. P.; DESLANDES, S. F. G GARNELO, L. Modos de vida e modos de beber de jovens indígenas em um contexto de transformações. Ciência G Saúde Coletiva; 15(3): 709-716, 2010.

SOUZA, M. L. P.; SCHWEICKARDT, J. C. G GARNELO, L. O processo de alcoolização em populações indígenas do Alto Rio Negro e as limitações do Cage como instrumento de screening para dependência ao álcool. Revista de Psiquiatria Clínica, 34 (2): 90-96, 2007. 


\section{As Boas Palavras Mbyá-Guarani como Caminho para a Redução do Uso de Bebidas Alcoólicas ${ }^{1}$}

Ao ser compreendido como um sério problema de saúde pública da atualidade, o alcoolismo é definido pelas ciências biomédicas como uma doença crônica e fatal de indivíduos que possuem determinada predisposição orgânica para a dependência do álcool. Por isso se manifestaria de igual forma em todas as sociedades. Entretanto, estudos antropológicos demonstram que o alcoolismo assume configurações particulares de acordo com o contexto sociocultural onde ele acontece. Neste caso, para se compreender o fenômeno do alcoolismo deve-se considerar as dimensões culturais, coletivas, bem como os múltiplos fatores que contribuem para conformá-lo (Langdon, 1999). Se as causas do alcoolismo são múltiplas e determinadas pelo contexto, as estratégias terapêuticas construídas por cada grupo social também são diversas e como construções culturais precisam ser entendidas no âmbito do universo social em que são colocadas em prática.

Entre os anos de 2000 e 2006, os Mbyá-Guarani² do estado do Rio Grande do Sul (RS) desenvolveram um conjunto de ações para reduzir os danos causados pelo uso abusivo de bebidas alcoólicas. ${ }^{3}$ Os karaí e os xondaro marãgatu foram agentes de intervenção centrais nesse processo. Os primeiros são lideranças espirituais e especialistas de cura que possuem contato direto com os deuses $(n h a n d e r u)^{4}$ e por isso detêm o poder de receber as mensagens divinas, sendo os conhecedores das 'boas palavras'. Já os xondaro emergiram durante o processo de execução dessas atividades como os 'guardiões do espírito', os 'mensageiros dos karaî', que têm como missão levar as 'boas palavras' dos karaí às comunidades, aconselhando-as a reduzirem o consumo de álcool e a se portarem conforme os ensinamentos de nhanderu.

As atividades realizadas para a redução do consumo de álcool foram: 1) o diagnóstico antropológico participativo sobre a manifestação do alcoolismo entre os Mbyá (2000-2001); ${ }^{5}$ 2) três reuniões dos karaí sobre o uso abusivo de bebidas alcoólicas e alcoolismo realizadas nos anos de 2000, 2002 e 2003; 3) dois percursos terapêuticos dos xondaro marãgatu que aconteceram nos anos de 2002 e 2003. 
Para efeito da análise aqui apresentada se considerará o primeiro desses percursos, ocorrido em 2002.

O caminho da intervenção sobre o uso abusivo de bebidas alcoólicas mobilizou as práticas tradicionais de autoatenção à saúde (Menéndez, 2009) e a organização sociopolítica mbyá-guarani já existentes com o objetivo de realizar um trabalho de cunho comunitário. As reuniões dos karaí e os percursos dos xondaro marãgatu, ao se constituírem em desdobramentos do diagnóstico antropológico participativo, potencializaram uma das formas de autoatenção mbyá: a instituição do aconselhamento por meio das 'boas palavras'.

\section{O processo de alcoolização entre os Mbyá-Guarani}

O fenômeno do uso de bebidas alcoólicas entre os Mbyá-Guarani situa-se no interior de uma cultura do contato (Cardoso de Oliveira, 1976) que emerge com as relações interétnicas estabelecidas no decorrer do processo histórico. Ao consumo de álcool se agrega um conjunto de práticas e significados que articula as concepções e o estilo tradicional de beber mbyá aos elementos provenientes da sociedade ocidental - alimentos, músicas, bebidas alcoólicas etc. - incorporados ao universo sociocultural deste grupo. Nesse processo, as bebidas alcoólicas e as práticas não indígenas associadas a elas são indigenizadas (Sahlins, 1997), propiciando o surgimento de uma 'cultura do beber' particular.

Atualmente existe uma grande diversidade de situações relacionadas ao uso de bebidas alcoólicas entre os Mbyá-Guarani no RS, que é influenciada pelas condições de vida particulares em que cada aldeia se encontra. Por um lado, é resultado do intenso processo histórico de contato interétnico; por outro, diz respeito à forma como estas comunidades criaram no decorrer do tempo mecanismos de atualização da sua cultura.

Do ponto de vista mbyá, os fatores que contribuem para a formação do fenômeno do consumo abusivo de álcool são: terra e ambiente natural insuficiente e/ou inadequado para a reprodução do modo de ser tradicional; proximidade dos grandes centros urbanos; acesso fácil às bebidas alcoólicas; trabalho assalariado fora da aldeia; conduta da liderança, ou seja, se faz uso de bebida alcoólica ou não; e a inexistência da opy (casa de reza), do karaí e da prática do conselho e, consequentemente, dos rituais tradicionais. As comunidades que não possuem casa de reza e que, portanto, não atualizam o seu calendário ritual particularmente encontram-se sem a proteção divina e à mercê de muitos perigos: doenças, mortes, brigas e outras calamidades (Ferreira, 2002).

A opy, espaço sagrado onde são realizados os rituais religiosos, protege a pessoa dos perigos das doenças e também de tornar-se cau (bebedor). Nesse sentido, a casa de reza desempenha um papel preventivo relacionado ao consumo de álcool, 
pois é ali que as crianças aprendem os cantos e as danças tradicionais e escutam os conselhos do karaí que as orientam a não fazerem uso de bebidas alcoólicas.

Nas comunidades em que não há opy os 'bailes de branco' animados por músicas sertanejas e os jogos de futebol tornaram-se práticas correntes. Também é aqui que encontramos uma maior incidência de casos de violência doméstica desencadeados pelo consumo de álcool, pois, geralmente quando estão embriagados, os casais brigam e separam-se em função do ciúme. Segundo o Mbyá José Cirilo Morinico, quando as pessoas bebem e dançam ao som da música sertaneja, o pensamento é direcionado para o sexo; ao passo que, com os cantos e a dança realizados na opy, o pensamento da pessoa mantém-se ligado a deus.

A inexistência do karaí ou a falta de autoridade e legitimidade de algumas lideranças para orientar o seu grupo com bons conselhos também contribui para incrementar o uso abusivo de bebidas alcoólicas nas comunidades mbyá. Isso ocorre principalmente em aldeias onde as lideranças políticas - os caciques - também bebem.

A cachaça (canha) é a bebida mais utilizada pelos Mbyá por ser compatível com o poder aquisitivo dos bebedores. A pessoa que não tem limite e tampouco controle para beber torna-se violento, afetando os seus parentes mais próximos. Dessa forma, ela passa a ser considerada um 'bebedor problema' não só porque consome álcool, mas principalmente porque cria problemas para a família e a comunidade.

O uso abusivo de álcool tem um impacto nocivo sobre a pessoa, ${ }^{6}$ pois compromete tanto as relações que ela mantém com a sua família e seus parentes, quanto com seu próprio espírito divino $\left(n h e^{\prime} e ̈\right)^{7}$ e com os deuses (nhanderu). Do ponto de vista cosmológico, aquele que bebe demais e perde o 'sentido' ultrapassa limites e faz coisas que não deve. Assim, age contra o seu espírito que, ao não ter alternativa, afasta-se dele, deixando-o sem proteção e à mercê das influências nocivas de espíritos malignos - mbogüa e anha ${ }^{8}$ - causadores de doenças que conduzem o bebedor a brigar com seus parentes ou a ser vítima de diferentes tipos de acidentes. Ou seja, a pessoa não adoece ou morre porque está bêbada, mas sim porque está sem a proteção de seu nhe'ë e, consequentemente, sem a proteção de nhanderu.

Segundo os Mbyá, na "canha habita um espírito que não tem parente", por isso ela gera desentendimentos entre membros de uma mesma família, sendo a violência doméstica um dos problemas mais sérios acarretados pelo uso abusivo de bebidas alcoólicas. Ao beber o espírito do corpo da pessoa (an) se 'apaixona' pelo espírito da canha, casando-se com ele. Isso faz com que o nhe'ë se afaste do bebedor, deixando-o à mercê dos muitos perigos espirituais que habitam o cosmos Mbyá.

Porque quando você está bebendo, quando você toma, não está pensando lá em cima. Você ama, você gosta, você se apaixona por beber. Porque essa bebida alcoólica tem espírito! Por que a pessoa não quer parar? Essa bebida 
tem espírito, e esse espírito casa com o corpo da pessoa. Esse é o princípio! Quando você se sente tonto por tomar bebida alcoólica, então se sente livre, sente uma coisa de natureza [vontade de fazer sexo], sente muita coisa. Esse espírito quando casa com a pessoa, a pessoa não quer parar nem um dia, parece que não vai conseguir parar! (karaí Marcelina Timóteo, Salto do Jacuí)

Outro problema que o uso de bebidas alcoólicas pode acarretar é fazer com que a pessoa, ao não seguir os ensinamentos de nhanderu, passe a ter uma vida sexual desregrada. Por um lado, existe o perigo de ela romper com as normas que regulam as relações sexuais (jerokuá) entre membros do próprio grupo; por outro lado, pode levá-la a ultrapassar fronteiras étnicas e fazer sexo com não índios, tornando-a vulnerável às doenças sexualmente transmissíveis.

Esse tipo de comportamento sexual desregrado também faz com que o nhe'ë se afaste da pessoa, causando doenças e até mesmo a morte.

Os brancos e as brancas, nós sabemos, trazem doença para nós. Não é só gonorreia, Aids. Nós sabemos muito bem. Se o espírito não tem força, ele se afasta na hora que você faz jerokuá [sexo] com o branco. Então essa é a doença. Tu morre na hora. E tem muitos homens e mulheres guarani que fizeram jerokuá com branco, e porque o espírito tem força ele não se afasta na hora, mas esta pessoa não dura muito, pode morrer a qualquer hora. (xondaro Agostinho Duarte, Inhacapetun)

Os rituais realizados na opy mantêm a pessoa ligada ao seu espírito, direcionando e concentrando os seus pensamentos em nhanderu, com os atributos de agregação e ordenação do cosmos. Em contrapartida, as bebidas alcoólicas consumidas em bailes, ao som das músicas sertanejas, direcionam o pensamento para o sexo, sendo o motor da violência, efeito desagregador do cosmos. Enquanto no primeiro caso as pessoas colocam-se sob a proteção da divindade, prevenindose dos perigos das doenças; no segundo, elas ultrapassam limites cosmológicos e ficam sem a proteção do nhe'ë e de nhanderu. Enquanto o canto e a dança realizados na casa de reza ensinam o rumo no qual a pessoa deve manter-se com saúde; as bebidas alcoólicas direcionam e abrem o caminho para os mbogüá, que causam doença e levam as pessoas à morte.

\section{O percurso dos xondaro marãgatu}

Durante a realização do diagnóstico antropológico participativo sobre a manifestação do alcoolismo entre os Mbyá-Guarani, os karaí entrevistados demonstraram a necessidade de uma reunião entre eles para conversarem sobre os problemas relacionados ao consumo de álcool e buscarem o caminho adequado para abordá-los. 
No final de 2000 foi realizada a I Reunião dos Karaí na Terra Indígena (TI) de Salto Grande do Jacuí, município de Salto do Jacuí (Ferreira, 2009), em que se deliberou que: 1) as reuniões deveriam prosseguir, em função da complexidade do problema e visando o fortalecimento dos karaí; 2) todas as comunidades do RS deveriam ter opy (casa de reza); 3) as 'boas palavras' seriam a forma adequada de abordar a questão do uso de bebidas alcoólicas. No fim da reunião, as lideranças mbyá elaboraram um documento-síntese sobre os temas abordados durante o evento, em que enfatizaram a importância de a medicina guarani atuar junto com a 'medicina do branco' para tratar os bebedores (cau) que almejassem parar de beber.

Primeiro conversamos sobre a forma de diminuir o uso das bebidas alcoólicas e daqueles que bebem. Para diminuir existe solução! Guarani sabe que tem remédio, só que esse remédio não é só o que se toma, também pode curar através de conselho e de reza: das 'boas palavras'. Para tratar o bebedor pode ser o remédio guarani e também o do branco. (Ferreira, 2009)

Um ano depois, em novembro de 2001, foi realizada a II Reunião dos Karaí na TI de Barra do Ouro, município de Maquiné. Nesse momento, escolheramse seis Mbyá para percorrer as comunidades com problemas causados pelo abuso do álcool, para levar os conselhos e as mensagens dos karaí. Este grupo de conselheiros foi chamado de xondaro marãgatu.

O primeiro percurso dos xondaro marãgatu, que ocorreu ao longo de 2002, foi realizado por uma equipe composta por cinco Mbyá provenientes de diferentes comunidades. Quatro deles eram xondaro - Artur de Souza, da aldeia de Coxilha da Cruz; Agostinho Duarte, da aldeia de Granja Vargas; Alexandre Acosta, da aldeia de Canta Galo e Cezário Timóteo, da aldeia de Barra do Ouro ${ }^{9}$ - e um deles liderança - José Cirilo Morinico, da aldeia de Lomba do Pinheiro -, que atuou como monitor e tradutor nas ações executadas. ${ }^{10}$

Entre os meses de outubro e dezembro, contando com transporte e diárias viabilizados pela Fundação Nacional de Saúde (Funasa), os xondaro marãgatu percorreram as comunidades de TI de Canta Galo, Viamão; TI de Inhacapetun, São Miguel das Missões; TI de Salto Grande do Jacuí, Salto do Jacuí; TI de Coxilha da Cruz, Barra do Ribeiro; TI de Barra do Ouro e Acampamento do Espraiado, Maquiné. ${ }^{11}$

Ao chegarem às comunidades os xondaro eram recebidos pelas lideranças da aldeia - caciques e karaí - e combinavam com elas como atuariam. No mesmo dia ou no outro, a liderança reunia o seu povo para escutar as importantes palavras que os visitantes estavam trazendo, solicitando a todos que se concentrassem para ouvi-las. 


\section{As 'boas palavras' dos xondaro marãgatu}

Nos eventos que congregaram os Mbyá-Guarani, tanto nos encontros promovidos pelos xondaro quanto nas reuniões dos karaí, o emprego das 'boas palavras', sempre acompanhadas pelo uso do petynguá (cachimbo), assume a forma de conselho e emerge como um recurso terapêutico no tratamento dos bebedores. Isso porque, como são palavras inspiradas pelo nhe'ë e por nhanderu, possuem o poder de emocionar as pessoas.

A 'boa palavra' é reconhecida não necessariamente pelo conteúdo do discurso daqueles que a empregam, mas sim pela entonação da voz da pessoa que está falando. Nos círculos de conversa, aquele que está com a palavra deve dirigirse ao centro da roda. Enquanto fala, caminha de um lado ao outro do círculo, no ritmo e na cadência da palavra proferida. As 'boas palavras' se constituem em um gênero de fala (Bakhtin, 1980) que integra o repertório da tradição oral mbyáguarani.

Para os Mbyá as palavras dos xondaro marãgatu vêm através dos deuses e do espírito, são palavras movidas pelo amor, por isso são belas e fazem com que as comunidades acreditem e tenham esperança no trabalho realizado. Os karaí das comunidades visitadas sempre reforçavam as palavras dos xondaro também utilizando a bela linguagem inspirada pelos deuses.

Eu espero que vocês também consigam mais palavras para passarem para nós. Não é vocês que têm essa palavra, você vai conseguir através de nosso deus que vai dar uma palavra para passar para outra pessoa. Como hoje você está falando, não é você que está falando, o deus que está dando uma palavra para você para falar para todos. Vai continuar iluminando para falar cada vez mais. (...) Então quem é que vai dar as palavras para nós? É o sol. Cada vez que estamos levantando, o sol nos acompanha para falar, para sorrir. Eu fiquei muito contente de estar com vocês, só por isso que estou falando um pouquinho, não é porque estou sabendo falar. As palavras de vocês me obrigaram a falar, porque tem espaço para falar. E daqui até a próxima. (karaí, Salto do Jacuí)

Segundo o karaí Juanzito, antigamente se ouviam mais esses conselhos do que atualmente, sendo poucos aqueles que empregam as palavras da forma como fazem os xondaro. O karaí explica que esses conselhos têm a sua origem "no centro do Paraguai e hoje têm poucos que ainda sabem esse sistema". Muitos dos problemas que acontecem no dia a dia das comunidades se deveriam ao fato de as 'boas palavras' proferidas por meio dos conselhos não estarem sendo mais empregadas pelos Mbyá. 
Em uma das reuniões dos karaí, o rezador Anúncio Benitez esclarece que quando os karaí falam que, "xondaro verdadeiro nasceu desde que existe a terra, só que agora é que está se revelando. (...) A gente não sabia que existiam os xondaro marãgatu, mas hoje nós karaí acreditamos que eles vêm dos deuses para dar força para nós. Para isso é xondaro marãgatu".

Entretanto, mesmo aqueles que empregam essas palavras compartilham da natureza da terra imperfeita em que vivem, eles são pessoas teko achÿ (vida doente), também imperfeitas e por isso alguns deles também gostam de beber.

Não é pela minha parte que estou falando, estou falando através de Deus. Eu tenho dor no coração. (...) Como nós somos pessoas teko achÿ, nós fazemos aquilo que não presta para nós. Nós tomamos aquilo que o branco toma. Então isso é teko vaekué [vida feia]. Esse teko vaekué acontece em todas as comunidades. Para falar direto: é canha. A canha é doença. Esse é o nosso pensamento para contar para vocês, só para isso que nós estamos aqui. (xondaro Alexandre, Inhacapetun)

De qualquer forma, uma das atribuições dos xondaro é traduzir as palavras dos karaí para uma linguagem mais comum de modo que sua mensagem se torne acessível a todos, principalmente aos jovens e às crianças. Já que um dos seus principais compromissos é orientar as famílias a cuidarem bem de suas crianças, garantindo condições para que as mesmas tenham um bom crescimento. ${ }^{12}$

E o que dizem as 'boas palavras'? Sobre o que falam os xondaro marãgatu?

Os xondaro vão falar sobre a importância da cultura, a importância das crianças, para o pai e a mãe pensar em ficar na aldeia, não ficar caminhando para lá e para cá. Isso é que xondaro marãgatu vai conversar com as famílias. Para isso é xondaro marãgatu. Nós temos que procurar mostrar coisas boas para as crianças, coisa boa é plantação. $O$ pai e a mãe têm que pensar como é que seu filho vai ter saúde. Essa mensagem que os xondaro marãgatu vão levar para as comunidades. (xondaro Agostinho, Acampamento Espraiado)

Os xondaro marãgatu, ao abordarem nas aldeias o tema do uso abusivo de bebidas alcoólicas preocupavam-se em não afrontar as comunidades com palavras de 'cobrança', pois isso os impediria de serem escutados. Ao contrário, sempre deixaram claro para todos que, mesmo estando com a responsabilidade de transmitir a mensagem dos karaí, eles não possuíam mais 'sabedoria' do que os demais e que todos deveriam falar e contar a sua experiência, pois também estavam ali para ouvir e aprender com as comunidades.

Não é para falar só nós três, todo mundo que está aqui deve falar, qualquer mulher pode falar. Porque tem mulher que tem irmão bebedor e sofre com 
o irmão, ela também deve falar. Nós viemos para ouvir de vocês também o que estão sentindo, o que estão sofrendo, o que precisam. Nós não estamos trazendo só a nossa palavra, nós queremos aprender com vocês. Qualquer um, qualquer jovem tem que falar e nós vamos ouvir. Para que todos deem ajuda um ao outro. Isso é que vai nos dar força. Se a gente cuida da criança desde pequeninha, ela vai crescer pensando. E nós temos que acompanhar o pensamento dela. (xondaro Agostinho, Inhacapetun)

Os xondaro sempre iniciavam o seu discurso buscando esclarecer as origens, o caráter e os objetivos do trabalho que realizavam. Explicavam que tinham sido escolhidos como grupo de conselheiros para falarem para todos.

Só por isso que nós juntamos todos, só por isso que nós juntamos os jovens, porque é importante ouvir. Então esse trabalho foi pensado não através de nós, mas através de nossos karaí. Foi a preocupação do karaí com a canha. Nós levamos mensagem para toda comunidade para saberem e conhecerem mais sobre o que é bom e o que é ruim para nós. O que traz problema é a canha. (liderança José Cirilo, Salto do Jacuí)

Logo em seguida passavam a relembrar as motivações de nhanderu para enviá-los a este mundo e resgatar as orientações deixadas por eles a fim de que seus filhos tivessem força (mbaraeté) e coragem (pyaguaçu ${ }^{13}$ para viverem nesta terra imperfeita.

Nosso pai, ele mandou aqui na terra para viver, para rezar, deixaram opy para nós guarani ter alegria. Se não tem opy, karaí não vai saber como tem que tratar aquele doente. Aí que os karaí vai dizer por que motivo você fica muito fraco, porque que o espírito não está ficando contente pelo seu corpo. Karaí que vai saber do corpo, por isso que é importante opy. (karaí Mariano, Coxilha da Cruz)

Assim, os xondaro esclareciam os seus parentes sobre o caminho que os deuses indicaram para os Mbyá seguir, reforçando a necessidade de as comunidades terem opye plantação (maety). Essas são condições fundamentais para a atualização da conexão das mesmas com nhanderu, de modo a permitir tanto o acesso às suas mensagens divinas quanto a manutenção da saúde e da felicidade.

A bebida alcoólica traz muita coisa. (...) Nosso Deus não nos mandou na terra para bebermos, não disse para aprendermos a beber com outro povo. (...) Os que estão morando aqui, procurem não tomar mais bebida alcoólica! Tem muita coisa que acontece em todas as aldeias e aconteceu o que nunca se viu. Procurem diminuir a bebida alcoólica. Que falta para a criança? Que falta para o adulto? Que falta para a mãe, para o pai? Que falta aqui na 
terra? Para mim é plantar milho para que as crianças vejam e tenham saúde. Isso é que é importante, isso é que é futuro para nós. Nós temos que pensar, plantar. Isso é bom para espírito também. Depois disso tem opy. É através da opy que a criança vai ficar com saúde, é aí que o espírito vai chegar e vai ter força através da opy. Por que alguma vez as crianças levantam sem força? Ficam magrinhas, tristes, não querem brincar, por quê? Por falta da opy. As crianças queriam ouvir o som do violão. Eu não estou dizendo que vocês sabem. Eu quero que vocês me desculpem. As crianças não podem estar sem nome, tem que ter batismo, ser batizada a criança, por isso é importante a opy. Quando recebe o nome o espírito fica contente, ele tem força. Por isso precisa nome - kuaray, karaí, verá. (...) Nós temos que valorizar nossa aldeia, não pode acontecer baile dos brancos. E quando tem aldeia nós temos que ter opy, a dança tradicional para aprender a nossa cultura, sistema e tradição. Nós queremos que todas as comunidades sejam assim. Nós temos que diminuir a bebida alcoólica. Isso que é importante para nós. Só para isso que eu estou falando agora. (xondaro Alexandre da Costa, Coxilha da Cruz)

Os xondaro propunham uma reflexão sobre as consequências do consumo de álcool sobre a vida e a forma de viver (nhandé rekó) mbyá-guarani. Para isso, perguntavam: "Como fazer para melhorarmos a nossa vida e termos felicidade?". Ao expressar a sua preocupação com o futuro, as mudanças culturais no próprio modo de ser mbyá provocadas pelo consumo de álcool passavam a ser tema de debate. Nesses diálogos, chegaram à conclusão de que a canha os enfraquece e compromete o seu futuro, principalmente, por ameaçar o bem-estar das crianças.

No entendimento mbyá, o nhanderu envia os espíritos das crianças à terra, aconselhando-os a acompanharem e fortalecerem os seus pais terrenos, trazendo alegria para a família. A família é a responsável pela educação das crianças. Quando começam a engatinhar, elas precisam ser batizadas e ganhar seu nome e assim terem força e saúde. O karaí é que vai dizer do que aquela criança precisa para ser saudável. Esse conhecimento vem por meio da reza que lhe propicia estabelecer contato com os deuses. Por exemplo: algumas crianças precisam ficar perto da opy para "mostrarem o seu corpo bem", senão a criança pode deixar o seu "corpo como terra" (yvyramo). ${ }^{14}$

Entretanto, devido ao consumo de bebidas alcoólicas, hoje em dia não se sabe mais por que os deuses mandaram os espíritos das crianças. Com isso, muitas vezes seus pais as maltratam e fazem com que seu nhe'ë se afaste, levando a criança à morte. Os pais não sabem mais aconselhar os filhos para educá-los. Por isso, uma das fortes preocupações dos xondaro se refere à situação das crianças que são filhas de pai e/ou mãe bebedores, que acabam por ensinar as crianças a beberem desde cedo. 
Diante desse problema, os xondaro aconselham os pais de família a respeitarem as crianças, pois foram os deuses que mandaram os seus espíritos para a terra.

Agora é difícil para o pai e para a mãe falarem para seus filhos, eles já não sabem mais como educá-los. Por que nosso pai nos mandou aqui na terra? Quando nosso Pai manda as crianças para nós é para que a mãe ou o pai tenham força [mbaraeté] e coragem [pyaguaçu]. Hoje em dia, a gente não sabe mais por que as crianças nasceram para nós, a gente não sabe mais como tratar as crianças. Hoje em dia, o marido a esposa têm que respeitar seus filhos. $O$ que é importante para as crianças? As crianças querem ver a plantação, algumas crianças querem ver a casa tradicional [opy]. Então algumas crianças choram porque necessitam de alguma coisa, necessitam de opy, de plantação. Então o pai e a mãe não sabem por que eles estão chorando e batem em seus filhos. Hoje em dia é assim, o pai e a mãe batem no filho, na filha, sem saber por que ele está chorando. Então essa coisa é muita dor para os velhinhos e para as velhinhas. Isso não pode acontecer na frente deles. Eu sempre digo assim: nós temos que voltar um pouquinho a viver como nossos antepassados (liderança José Cirilo, Salto do Jacuí)

Os xondaro também consideram o sofrimento dos familiares e parentes que possuem um 'bebedor' na família. A bebida alcoólica os faz adoecer de dor no coração (pyarachy), porque ela, a bebida alcoólica é sozinha "não tem parente: nem irmão, nem pai e nem mãe".

Saudações, meus parentes. Eu também não sei falar muita coisa. Eu também vou falar um pouco sobre a bebida alcoólica. Eu também era feio, cau. Nossos parentes estão diminuindo, já perdemos muito. Muitos dos nossos parentes já ficaram com o corpo como terra [yvyramo] só por causa da bebida alcoólica. Eu conheço também porque eu era bebedor. Então por isso que é importante de cada aldeia ter opy. Os mais velhos e mais velhas sofreram muito por causa disso, quando o filho ou a filha é bebedor. Então, quando o filho ou a filha falam assim: quando estou bebendo o problema é meu, sou eu. Mas se ele morre, isso é mau para todos, isso é dor. Quando o meu parente morre, vem o sofrimento para todos. (...) Os karaí estão orientando para não chegarmos ao ponto de cairmos num buraco e morrermos. Então, por isso que os mais velhos se preocupam, por causa da morte. (xondaro Cezário, Salto do Jacuí)

Ainda em relação à preocupação com a família, os xondaro vão conversar sobre a separação entre os casais mbyá, fenômeno cada vez mais recorrente e que tem no uso abusivo de bebidas alcoólicas uma das principais causas. A separação dos casais é um problema porque cria doença, sofrimento e dor no coração. Para os 
karaí, isso acontece entre os Mbyá em virtude da falta de, "obediência a deus! As pessoas esqueceram-se de deus, não levantam mais com o sol, agora levantam com o anhã e já entregaram tudo para os espíritos dos mortos" (karaí Juanzito, Salto do Jacuí).

O karaí Juanzito, então, aconselha os casais a tratarem-se bem, afirmando que é necessário que cada cônjuge saiba tratar o(a) companheiro(a) e evite a violência doméstica desencadeada pelo consumo de álcool.

Quando falamos de casamento, tem que mostrar bem para o parente um casal certo, de verdade. Isso que é importante para nós. Quando separa casando com outro e assim continua, isso não é bom para nós. O jovem quando casa, tem que tratar bem a sua esposa. Não pode dar sofrimento para a mulher. A mulher e o homem são a mesma coisa: não pode dar sofrimento nem para a mulher nem para o homem. (...) Todos os que casam tem que procurar viver bem. Não quero que continuem assim. Essa separação existe em todas as partes, não é só aqui. (...) Tem ainda quando o pai da sua filha bebe e fala bobagem. Aí a mulher fica sofrendo, porque ela não bebe. Então isso acontece com alguns casais, isso é que causa dor. Então isso acontece com alguns casais, causando dor e fazendo chegar o momento de entregar o corpo para anhã ou mbogüa. Nós não podemos continuar assim. Se casal bebe junto não tem controle. (karaí Juanzito, Salto do Jacuí)

Uma das palavras dos xondaro às comunidades foi sobre a necessidade das mesmas valorizarem e ouvirem os mais velhos e os karaí, porque eles sofreram e sofrem muito devido ao consumo abusivo de álcool feito pelos seus parentes. Além disso, os jovens já não ouvem mais os seus conselhos, considerando-os coisas do passado.

Hoje em dia, a maior parte das pessoas não sabe mais o que significa a manifestação dos deuses - a caminhada de nhamandu [sol]; a mão brilhante de Tupã [trovão] -, não conhecem mais as palavras divinas. Os conhecedores destas palavras são os karaí e estes são poucos, porque (...) os mais velhos e mais velhas não aguentaram a maldade que cada vez aumenta mais neste mundo, na terra velha, por isso eles 'viraram como terra' e não alcançaram a terra sem mal. (liderança José Cirilo, Salto do Jacuí)

Os xondaro marãgatu abriram um espaço nas comunidades visitadas para que os karaí aconselhassem e transmitissem a sua sabedoria (arandu) aos parentes. O conselho dado pelos karaí diretamente aos bebedores foi para que eles rezassem e contassem o seu problema, a sua dor, a sua doença para nhanderu ou para os que 'usam o cachimbo'. Que 'mostrassem o corpo' para os karaí para que eles o apresentassem para os deuses. 
Também esse foi o momento dos Mbyá ouvirem as palavras divinas, chamadas ayvu nhetiró ou ayvu rapitá, definidas como as 'palavras-escada', por elevarem o pensamento das pessoas para o alto. Poucos são os que sabem falar ayvu nhetiró atualmente.

Muito obrigado aos chefes dos xondaro! E nosso irmão que colocou umas palavras bonitas. Eu fiquei muito bem com vocês. Já que nós estamos aqui para conversar sobre isso, que nosso nhamandu quando vem nascendo traz umas palavras para nós e para todos. Nhamandu, ele trouxe suas mãos brilhantes, o peito brilhante para que nós, os filhos, levantassem bem, todos os seres humanos para levantarem bem, os bichinhos também, todos que estão aqui no mundo com a mão e com o peito brilhante foram levantados e nós também. (karaí Henrique, Canta Galo)

Nesse sentido, além de estimularem as comunidades a refletirem sobre o impacto do consumo abusivo de bebidas alcoólicas sobre a pessoa e o modo de ser mbyá-guarani e sobre a necessidade de 'acordarem' e se organizarem para enfrentar os problemas desencadeados por esse consumo, os encontros promovidos pelos xondaro marãgatu foram momentos de atualização da linguagem sagrada, de valorização do modo de ser tradicional e de fortalecimento da opy e dos karaí Mbyá-Guarani.

\section{Resultados e lições aprendidas}

Os eventos comunicativos propiciados pelo percurso dos xondaro marãgatu se constituíram em momentos de reafirmação da identidade sociocultural desse grupo étnico, na medida em que propiciou aos Mbyá refletir sobre os problemas que hoje os afligem, visando à criação de estratégias para solucioná-los ou mesmo minimizá-los. Ao conversar sobre a situação de suas comunidades no que tange ao uso do álcool e buscar alternativas para enfrentar esse problema a partir de seu próprio sistema médico tradicional, os Mbyá atualizaram, recriaram e fortaleceram o seu próprio modo de ser e, consequentemente, reforçaram a sua autoestima.

Por terem sido realizados segundo a orientação sociocultural mbyá, esses eventos adquiriram um caráter profilático e terapêutico em relação ao uso de bebidas alcoólicas, já que as 'boas palavras', como uma prática de autoatenção, possui o poder de emocionar e de estabelecer a ligação da pessoa com seu espírito divino.

Na III Reunião dos Karaí realizada em 2003, as lideranças mbyá avaliaram o trabalho dos xondaro e falaram dos resultados alcançados com a iniciativa: a própria formação do grupo de conselheiros das 'boas palavras'; a união das lideranças - karaí, caciques e xondaro - e das comunidades do RS para o enfrentamento da problemática do uso abusivo de bebidas alcoólicas; o resgate e o fortalecimento 
da instituição do conselho por meio das 'boas palavras'; e a valorização dos karaí, das opy e da sabedoria mbyá-guarani. Também chegaram à conclusão de que houve significativa redução do consumo de álcool e dos danos causados pelo mesmo em algumas comunidades.

Estas ações abriram espaço para nós discutirmos entre os guarani sobre a preocupação com o problema da bebida alcoólica. (...) Eu estou percebendo que nós não estamos mais ligados com a natureza por causa da bebida alcoólica. Por que a gente não recebe mais recado dos deuses? Por causa da bebida alcoólica. Por que não existe mais Guarani vivendo aqui nessa terra na forma deixada por deus? Por causa da bebida alcoólica. Quais são os resultados deste trabalho que estamos vendo? Algumas comunidades construíram opy. Nessa batalha nós estamos lutando contra a bebida alcoólica, contra a maldade que traz briga. Não estamos lutando contra as pessoas, contra os nossos parentes. Estamos lutando contra o espírito da bebida alcoólica. É isso que nós estamos enfrentando. (...) O trabalho sobre a bebida alcoólica abriu espaço para falarmos sobre a preocupação com os karaí. Hoje diminuíram os karaí, porque a gente não os valoriza mais. (...) Porque se não tivesse esse trabalho, os Guarani ficariam cada vez mais fracos, esquecendo da cultura. Aí vai terminando os guarani, vai terminando o sistema. Então minha avaliação é essa (...). Esse trabalho trouxe muitos frutos, porque estamos falando do enfraquecimento da nossa sabedoria, dos nossos karaí, das crianças que já não têm mais batismo. Agora a gente lembrou. Através desse trabalho lembramos e acordamos todos. Esse é o resultado. (...) Hoje nós avançamos muito no caminho para diminuir o consumo do álcool. Hoje, diminuiu o uso desse álcool, diminuiu as festas de branco em algumas comunidades, e também alguns bebedores já pararam de tomar, e outros que não pararam de tomar, mas já não batem mais em suas esposas e nem brigam mais com seus parentes. (liderança José Cirilo Morinico, Salto do Jacuí)

O processo de pesquisa e intervenção sobre o uso abusivo de bebidas alcoólicas entre os Mbyá-Guarani no RS, o qual deu origem ao percurso dos xondaro marãgatu, demonstrou a capacidade criativa deste povo indígena para a construção de estratégias de enfrentamento dos problemas de saúde vivenciados por eles no cotidiano de suas comunidades. Por emergirem no contexto sociomédico mbyá, em que estão inscritos os saberes e as práticas indígenas de cuidados com a saúde, tais estratégias revelam tanto a perspectiva indígena sobre tais agravos, quanto as formas de decisão acerca das prioridades e dos métodos de intervenção sobre os mesmos, como é o caso do alcoolismo e do uso abusivo de bebidas alcoólicas aqui abordado. 
Além disso, como se pôde perceber, as 'boas palavras' veiculadas pelos karaí e pelos xondaro marãgatu não só estavam voltadas para a redução dos danos causados pelo abuso de álcool, mas também se constituíram em estratégias de promoção à saúde e prevenção das doenças, estando alinhadas ao discurso cosmológico que informa a organização social deste povo.

Uma importante lição aprendida se refere à conveniência dos serviços de saúde de compreenderem e levarem a sério os modos indígenas de fazer saúde de forma a se adequarem às realidades socioculturais diferenciadas onde deverão atuar. No caso do abuso de álcool e do alcoolismo, assim como de outros agravos, convém que sejam construídas conjuntamente com estes povos rotinas de cuidados com a saúde baseadas na articulação entre os sistemas sociomédicos indígenas (Fóller, 2004) e os serviços de saúde. Os próprios Mbyá, durante todo o processo, apontaram para a importância da medicina indígena e da medicina do branco trabalharem conjuntamente para tratarem dos 'bebedores' (cau) que almejam parar de beber. Assim se estaria atendendo ao preconizado pela Política Nacional de Atenção à Saúde dos Povos Indígenas (Brasil, 2002) e efetivando o direito destes povos a uma atenção diferenciada a sua saúde.

Entretanto, se os conselhos dados pelos karaí e pelos xondaro marãgatu aos parentes Mbyá alcançaram resultados na redução dos danos causados pelo abuso do álcool, foi principalmente por estimular as comunidades a se organizarem para o enfrentamento do problema no âmbito das relações sociais atuando, portanto, no nível do coletivo. No plano individual do tratamento e recuperação dos bebedores, não houve avanços significativos no que se refere ao desenvolvimento de projetos terapêuticos culturalmente adequados, baseados na articulação entre o sistema médico mbyá e os serviços de saúde.

Notas

1 Este capítulo é uma versão revisada de: Ferreira, L. O. As "boas palavras" dos xondaro Marãgatu como alternativa para a redução do consumo de bebidas alcoólicas entre os Mbyá-Guarani - RS. Tellus, 4(7): 121-135, 2004. Texto publicado com autorização da autora e do editor da revista.

2 A sociedade mbyá-guarani pertence ao tronco linguístico tupi, família linguística tupi-guarani, dialeto mbyá. Em 2008 os Mbyá contavam com uma população de aproximadamente 1.600 indivíduos, organizados em 418 famílias nucleares distribuídas em aproximadamente 27 aldeias (Brasil, 2008).

3 Tais ações contaram com a coordenação antropológica da autora e foram viabilizadas por meio de uma parceria estabelecida entre lideranças mbyá e a Fundação Nacional de Saúde, sendo financiadas pelo Projeto Vigisus/Funasa.

4 Os karaí são denominados por Melià (1988: 60) também pelo termo ipajé. "El ipaje dentro de la comunidad es como un catalizador de mediaciones espirituales en el campo de la salud, de la 
agricultura y del gobierno (...) Son hombres carismáticos, cuyo saber y capacidad no les viene por enseñanza ni aprendizaje, sino por inspiración, por naturaleza".

5 Os objetivos do diagnóstico foram: 1) identificar se o uso de bebidas alcoólicas era um problema para os Mbyá; 2) caracterizar o processo de alcoolização (Souza G Garnelo, 2006) vivenciado por esse povo indígena no RS; 3) levantar as práticas de autoatenção utilizadas para o controle do consumo de álcool. Para mais informações sobre o fenômeno do uso de bebidas alcoólicas entre os Mbyá no RS, ver Ferreira (2004).

6 Para os Mbyá-Guarani, a pessoa possui duas almas: uma de natureza divina (nhe'ë), proveniente dos deuses cosmogônicos; outra, de natureza telúrica - princípio terrestre que a pessoa adquire quando a alma divina encarna na terra, que se chama an. Depois da morte, o nhe'ë retorna à morada de seus pais divinos e o an transforma-se em angue ou mbogüá, espírito dos mortos que causam doenças (Schaden, 1962; Nimuendajú, 1987; Clastres, 1978; Cadogan, 1997).

7 "Espécie de espírito protetor, a quem incumbe a segurança do indivíduo, vigiando-o. (...) É parte integrante do seu eu. (...) A sede da alma (...) é o corpo todo. Os nhe'ë caracterizam-se por existência relativamente livre, isto é, existem independentemente do corpo, podendo deixá-lo (...) e retirar-se para regiões longínquas" (Schaden, 1962: 137-138).

8 Espécie de espírito demoníaco que causa muitas perturbações ao se aproximar dos Mbyá.

9 Dois dos Mbyá escolhidos na II Reunião para serem xondaro não participaram do percurso por estarem impedidos de viajarem na ocasião.

10 As 'boas palavras' aqui apresentadas foram proferidas na língua guarani e traduzidas para o português por José Cirilo Pires Morinico.

11 Foram feitas dez saídas de campo com duração de cinco dias cada. Em cada saída cinco pessoas participavam: o motorista da Funasa, a antropóloga, o monitor mbyá e dois xondaro marãgatu, que se revezavam de acordo com o local a ser visitado.

12 Diferentes tipos de palavras são usadas nos encontros promovidos pelos xondaro marãgatu: ayvu porã = boas palavras; ayvu teko achÿ = palavras comuns, deste mundo; ayvu achojavapy = palavras dos espíritos; e ayvu nhetiró (rapitá) = palavras divinas, 'palavras-escada'.

13 Duas são as virtudes mbyá-guarani que emergem através das 'boas palavras' proferidas pelos karaí e xondaro marãgatu: mbaraeté, traduzida como força, fortaleza, saúde, a condição para não envelhecer e manter a vida no corpo, para alcançar a moradia dos deuses com o corpo e tudo e lá nascer de novo, voltar a ser criança; e pyaguaçu, traduzida como o sentimento de coragem necessário para enfrentar a maldade (sofrimento, morte, doença).

14 Os xondaro marãgatu raramente referem-se diretamente à morte (omaino1̂) de um parente. Geralmente a palavra sagrada usada é yvyramo, que quer dizer que o parente "deixou o seu corpo como terra". 


\section{Referências}

BAKHTIN, M. The problem of speech genres. In: EMERSON, C. G HOLQUIST, M. (Eds.). Speech Genres and other Late Essays. Austin: University of Austin Press, 1980.

BRASIL. Fundação Nacional de Saúde. Política Nacional de Atenção a Saúde dos Povos Indígenas. Brasília: Ministério da Saúde, Fundação Nacional de Saúde, 2002.

BRASIL. Ministério da Saúde. Sistema de Informação da Atenção à Saúde Indígena (Siasi). Site. Disponível em: <portal.saude.gov.br/portal/saude/Gestor/visualizar_texto.cfm? idtxt $=40846>$. Acesso em: 2008.

CADOGAN, L. AyvuRapyta: textos míticos de los Mbyá-Guaraní del Guairá. Asunción: Biblioteca Paraguaya de Antropología, 1997.

CARDOSO DE OLIVEIRA, R. Identidade, Etnia e Estrutura Social. São Paulo: Livraria Pioneira, 1976.

CLASTRES, H. A Terra sem Mal. São Paulo: Brasiliense, 1978.

FERREIRA, L. Relatório Final: diagnóstico participativo antropológico sobre a manifestação do alcoolismo entre os Mbyá-Guarani. Porto Alegre: Projeto Vigisus, Funasa, 2002.

FERREIRA, L. O fazer antropológico em ações voltadas para a redução do uso abusivo de bebidas alcoólicas entre os Mbyá-Guarani no RS. In: LANGDON, J. G GARNELO, L. (Orgs.). Saúde dos Povos Indígenas: reflexões sobre antropologia participativa. Rio de Janeiro: Contra Capa, ABA, 2004.

FERREIRA, L. O. A emergência das boas palavras na I Reunião Karaí sobre o uso abusivo de bebidas alcoólicas e alcoolismo no RS. In: FERREIRA DA SILVA, G.; PENNA, R. G CARNEIRO, L. C. C. (Orgs.). RS Índio: cartografias sobre a produção do conhecimento. Porto Alegre: EdiPUCRS, 2009.

FÓLLER, M. Intermedicalidade: a zona de contato criada por povos indígenas e profissionais de saúde. In: LANGDON, J. G GARNELO, L. (Orgs.). Saúde dos Povos Indígenas: reflexões sobre antropologia participativa. Rio de Janeiro: Contracapa, 2004.

LANGDON, J. O que beber, como beber, e quando beber: o contexto sociocultural no alcoolismo entre as populações. In: LANGDON, J. Saúde, Saberes e Ética: três conferências sobre antropologia da saúde. Florianópolis: Programa de Pós-Graduação em Antropologia Social, Universidade Federal de Santa Catarina, 1999. (Antropologia em Primeira Mão)

MELIÀ, B. Los Guarani-Chiriguano: ñande rekó, nuestro modo de ser. La Paz: Cipca, 1988.

MENÉNDEZ, E. Modelos de atenção dos padecimentos: exclusões ideológicas e articulações práticas. In: MENÉNDEZ, E. Sujeitos, Saberes e Estruturas: uma introdução ao enfoque relacional no estudo da saúde coletiva. São Paulo: Hucitec, 2009.

NIMUENDAJÚ UNKEL, C. As Lendas de Criação e Destruição do Mundo como Fundamentos da Religião dos Apapocúva-Guarani. São Paulo: Hucitec, Edusp, 1987. 
SAHLINS, M. O 'pessimismo sentimental' e a experiência etnográfica: porque a cultura não é um objeto em via de extinção (parte 1). Mana, 3(1): 41-73, 1997.

SCHADEN, E. Aspectos Fundamentais da Cultura Guarani. São Paulo: Difusão Europeia do Livro, 1962.

SOUZA, M. G GARNELO, L. Desconstruindo o alcoolismo: notas a partir da construção do objeto de pesquisa no contexto indígena. Revista Latinoamericana de Psicopatologia Fundamental, IX(2): 279-292, 2006. 


\section{Problemas Relacionados ao Uso de Álcool entre Indígenas Guarani no Estado do Rio de Janeiro: uma experiência de abordagem terapêutica integrada ${ }^{1}$}

Maria de Betania Garcia Chaves, Andrey Moreira Cardoso e Salette Maria Barros Ferreira

Os Guarani que vivem no estado do Rio de Janeiro, assim como a maioria dos povos indígenas em território brasileiro, têm sofrido um processo acelerado de transformações socioculturais atreladas ao progressivo e intenso contato com a sociedade nacional (Litaiff, 1996; Cardoso, 2000). Esse processo, que ocorre de forma concomitante à degradação dos ecossistemas dos quais se utilizam no cotidiano, interfere nos aspectos mais diversos da vida indígena, resultando em carência dos recursos naturais para subsistência e em uma nova dinâmica na relação com a sociedade envolvente. A modificação e a introdução de novos hábitos e comportamentos entre os indígenas têm propiciado o surgimento de novos agravos à saúde, tais como as doenças crônicas não transmissíveis, a exemplo do diabetes mellitus e da hipertensão arterial (Cardoso, Mattos G Koifman, 2001, 2003), e problemas relacionados ao consumo de bebidas alcoólicas, conforme já descrito em povos originários de outros países (Kunitz G Levy, 1994).

No Brasil, o uso de álcool em sociedades indígenas e sua repercussão sobre as relações sociais e familiares e sobre a saúde dos indivíduos e grupos têm sido mais discutidos nos anos recentes (Souza G Garnelo, 2007; Souza, Oliveira G Kohatsu, 2003; Langdon, 2001). ${ }^{2}$ Entretanto, ainda hoje são escassas as iniciativas para melhor caracterizar o problema, sobretudo pelos desafios metodológicos para abordar essa questão em grupos culturalmente diferenciados. Além disso, por ser recente o reconhecimento do consumo prejudicial do álcool como matéria pertencente à interseção dos campos da saúde pública e da saúde mental (Delgado, 2005), esse reconhecimento aplicado à saúde indígena é ainda mais recente, fato que resulta na produção insuficiente de evidências científicas capazes de orientar a Política de Atenção Integral à Saúde Mental das Populações Indígenas. Isso é agravado pela grande diversidade sociocultural indígena existente no país, o que dificulta a identificação de padrões de consumo generalizáveis e de propostas de intervenção aplicáveis nos diferentes contextos.

Portanto, para a elaboração de propostas socioculturalmente adequadas, torna-se necessária a compreensão dos modos como os povos indígenas fazem uso 
de bebidas alcoólicas, sendo importante minimizar as potenciais tensões advindas da prática da atenção à saúde em um ambiente de contato intercultural. Caminhando no sentido de construir uma oferta de rede de cuidados à saúde indígena, no âmbito da saúde pública, considera-se de vital importância a compreensão dos valores, atitudes e crenças dos povos indígenas (Barros, 2003), reconhecimento que deve embasar qualquer ação de planejamento em saúde, incluindo todos os níveis de atenção.

Essa visão decorre da perspectiva compartilhada por alguns autores das ciências sociais de que, por ser a ingestão de bebida alcoólica um ato social, tal como exemplificado por Velho (1994:87) ao afirmar que diferentes culturas criam "espaços próprios para consumo dos mais variados tipos de drogas, muitas vezes em contextos religiosos, em rituais e cerimoniais específicos", o beber excessivo nada mais é que a denúncia coletiva de transgressão das regras inerentes ao ato de beber nessa sociedade (Neves, 2004). Assim, saúde pública, antropologia e sociologia devem buscar a abertura de um campo comum, fomentando um espaço de diálogo que permita o reconhecimento e a construção de uma abordagem conjunta dos problemas relacionados ao consumo de bebidas alcoólicas para esses povos.

Recentemente, o Ministério da Saúde (MS) buscou estabelecer diretrizes para uma Política de Atenção Integral à Saúde Mental das Populações Indígenas (Brasil, 2007), indicando a necessidade de escuta das instâncias representativas dessas comunidades no manejo de situações de saúde mental e, especificamente, de problemas relacionados ao consumo de bebidas alcoólicas, ressaltando também a pertinência de que as ações sejam articuladas entre as diferentes esferas de governo.

O trabalho aqui apresentado relata a experiência vivida, no período de 2001 a 2002, pela equipe responsável pela atenção à saúde dos Guarani no estado do Rio de Janeiro, na atenção demandada por alguns indígenas que identificaram o uso de bebida alcoólica como um problema. A abordagem terapêutica se deu de forma concomitante, por ações de saúde pautadas no estabelecimento de uma rede de cuidados resultante da integração multiprofissional, intersetorial e interinstitucional, e pelas práticas de cuidado desenvolvidas pelos próprios indígenas, com participação ativa de familiares, membros da comunidade e lideranças políticas e religiosas. Essas ações buscaram valorizar a compreensão do problema na perspectiva dos indígenas, bem como a identificação de soluções com base nessa visão.

\section{Política de álcool e outras drogas na interseção dos campos da saúde pública e da saúde mental no Brasil}

O consumo de álcool no mundo (OMS, 2002), assim como no Brasil (Brasil, 2003), é reconhecido como um grave problema de saúde pública, e ainda mais 
relevante entre grupos populacionais em desvantagem social e minorias étnicas, como os povos indígenas (Souza G Garnelo, 2007; Ferreira, 2004; Souza, Oliveira G Kohatsu, 2003; Langdon, 1999). Segundo levantamento epidemiológico de âmbito nacional realizado em 2002 pelo Centro Brasileiro de Informações sobre Drogas Psicotrópicas (Cebrid) (Carlini et al., 2002), o contingente da população dependente de álcool era de 11,2\%, confirmando assim o álcool como o principal problema de saúde pública no campo das drogas no Brasil.

Ainda que alcoolismo e drogadição, assim como suicídio, pertençam ao campo da saúde pública, em particular no âmbito dos problemas relacionados à saúde mental (OMS, 2002), essa chamada à responsabilidade das questões relacionadas ao cuidado a populações usuárias de álcool e outras drogas nesses dois campos (saúde pública e saúde mental) é recente, como ressalta Delgado (2005). Desde o final dos anos 1980, trabalhadores, gestores e usuários de saúde mental vêm construindo o redirecionamento do modelo de atenção psiquiátrica (Brasil, 2004), por meio da ruptura com a lógica predominantemente asilar, que privilegiava o manicômio como espaço indicado ao tratamento de agravos relacionados ao uso de álcool e outras drogas (Ferreira, 2000; Bittencourt, 1982). Apostou-se, portanto, em outra lógica, pautada em ações e dispositivos de cuidado multidisciplinares e de base territorial (Alves, 2006).

No período anterior à Política do Ministério da Saúde para a Atenção Integral a Usuários de Álcool e Outras Drogas (Brasil, 2003), os tratamentos para álcool e outras drogas eram realizados quase exclusivamente fora do campo da saúde, particularmente em três instâncias da sociedade: pelos grupos de ajuda mútua, os Alcoólicos Anônimos (AA) ou Narcóticos Anônimos (NA), ambos de iniciativa leiga e comunitária; em comunidades terapêuticas, na maioria das vezes de natureza filantrópica e religiosa (Delgado, 2005); e nas clínicas privadas, algumas de orientação médica, outras não necessariamente (Ferreira, 2007).

Dentre os dispositivos substitutivos do modelo asilar, a Política de Saúde Mental vem investindo na implementação dos Centros de Atenção Psicossocial (Caps), que, por serem serviços comunitários, devem atender aos postulados da integralidade e acessibilidade do Sistema Único de Saúde (SUS), e, portanto, de qualidade no cuidado.

Segundo Alves (2006:173),

se estes são comunitários, se inserem em determinada cultura, em território definido, com seus problemas e suas potencialidades, arena onde as 'crises' devem ser enfrentadas, resultado que são, geralmente, de fatores do indivíduo, de sua família, eventualmente de seu trabalho, e seguramente de seu meio social.

Atualmente, verifica-se uma mobilização a favor da reversão da histórica ausência de ações e políticas específicas de saúde pública dirigidas para essas 
clientelas. Delgado (2005: 172), discorrendo acerca da "dívida histórica da saúde pública com a questão do álcool e outras drogas" e procurando indicar prioridades para a construção de diretrizes gerais para uma política intersetorial para o álcool, ressalta que

o álcool (...) esteve perigosamente ausente das políticas púbicas no passado, especialmente em relação à saúde pública. Pela relevância que esta droga apresenta nas variadas consequências associadas ao seu consumo, (...), é necessário que se assuma a responsabilidade por essa lacuna. (Delgado, 2005: 172)

A ratificação desses avanços é alcançada em 2001, com a promulgação da lei n. 10.216, conhecida como Lei Paulo Delgado, que dispõe sobre a proteção e os direitos das pessoas portadoras de transtornos mentais e redireciona o modelo assistencial em saúde mental (Brasil, 2004). Esse momento, respaldado pelas recomendações da III Conferência Nacional de Saúde Mental, no mesmo ano, representou um movimento da saúde pública que alicerçou o estabelecimento da Política do Ministério da Saúde para Atenção Integral a Usuários de Álcool e Outras Drogas (Brasil, 2003).

\section{Abordagem terapêutica integrada aos problemas relacionados ao uso de álcool entre os Guarani no estado do Rio de Janeiro}

Em 1991, profissionais da Secretaria Municipal de Saúde (SMS) de Angra dos Reis deram início aos trabalhos de saúde na comunidade guarani da Aldeia Sapukai, localizada no Bracuí, desenvolvendo, com o apoio da Fundação Nacional do Índio (Funai), atividades de cunho preventivo e assistencial (Chaves, 2006). Esses trabalhos enfocaram, entre outros, problemas relacionados ao uso do álcool na área indígena, promovendo, para as populações indígena e não indígena do entorno da Aldeia Sapukai, ações que contribuíssem para o debate e a reflexão acerca do acesso e dos riscos do consumo de bebidas alcoólicas na localidade.

Nos anos subsequentes, houve uma intensificação das relações do poder público municipal com a população indígena da Aldeia Sapukai e esse progressivo compromisso com a questão indígena culminou, de acordo com as reivindicações da própria comunidade, na inauguração da primeira unidade municipal de saúde do país em área indígena, a Unidade de Saúde da Aldeia, em 1995. Esta unidade, cadastrada no SUS em parceria com a Fundação Nacional de Saúde (Funasa) e a Funai, lotou profissionais concursados para a Secretaria Municipal de Saúde de Angra dos Reis, possibilitando a ampliação do acesso dos indígenas aos serviços de saúde regionais, mediante a articulação dos serviços de atenção primária 
realizados na aldeia aos de maior complexidade de atenção, representados pelas redes municipal e estadual de saúde.

Com a promulgação da lei n. 9.836, de 1999 (Lei Arouca) (Brasil, 1999), instituiu-se o Subsistema de Atenção à Saúde Indígena (Sasi), componente do SUS, sob gestão da Funasa, ${ }^{3}$ o que propiciou a criação dos Distritos Sanitários Especiais Indígenas (DSEI). ${ }^{4}$ A partir de então, coube aos DSEI prestar atenção primária à população indígena residente nas aldeias por meio da atuação de Equipes Multidisciplinares de Saúde Indígena (EMSI), nos moldes da Estratégia de Saúde da Família (ESF). Assim, houve uma integração do Sasi à rede local, o que possibilitou a ampliação da assistência, já previamente existente na Aldeia Sapukai de Angra dos Reis, aos indígenas guarani residentes nas aldeias localizadas no município vizinho de Parati. Estes municípios compuseram o polo-base ${ }^{5}$ Angra dos Reis, um dos 11 polos-base integrantes do DSEI Litoral Sul.

Atendendo às recomendações do I Fórum Macrorregional Sul e Sudeste de Doenças Sexualmente Transmissíveis e Aids (DST/Aids) para populações indígenas, realizado em Londrina em 1997, a Funasa convidou a Secretaria de Estado de Saúde do Rio de Janeiro (SES/RJ), em 1999, a cooperar para viabilizar um projeto de prevenção às DST/Aids nas aldeias indígenas do Rio de Janeiro e em algumas aldeias de São Paulo, em parceria com o Núcleo de Estudos de Saúde de Populações Indígenas da Fundação Oswaldo Cruz (Nespi/Fiocruz) e as Secretarias Municipais de Saúde de Angra dos Reis e Parati. Para viabilizar esse projeto, os trabalhadores da saúde que atuavam diretamente na atenção aos Guarani (EMSI) e alguns trabalhadores das redes de saúde municipal e estadual que atendiam aos indígenas fora da aldeia participaram do I Seminário sobre Prevenção das DST/ Aids e Aspectos Antropológicos dos Povos Indígenas, realizado ainda no mesmo ano, na cidade do Rio de Janeiro (Chaves, 2006).

Posteriormente, em 2000, foram realizadas oficinas com as lideranças indígenas com o objetivo de formar multiplicadores. Na ocasião, os próprios indígenas identificaram o consumo do álcool como uma 'armadilha' para a transmissão das DST/Aids: os indígenas frequentam festas no entorno das aldeias, consomem bebidas alcoólicas, "ficam com a cabeça confusa e não sabem o que fazem". Essas afirmações, sustentadas por representações gráficas sobre contextos de vulnerabilidade à transmissão das DST/Aids, realizadas pelos indígenas participantes das oficinas, sugerem a exposição à relação sexual sem uso de preservativos em situações de uso de álcool entre eles. Essa ideia foi corroborada pelos achados de Marinho (2000), ao descrever um modelo de vulnerabilidade, por meio do Sistema de Informação Geográfica (SIG), que identificou nos municípios do Sul Fluminense fatores físicos de vulnerabilidade às DST/Aids para a população indígena, tais como bares e prostíbulos. 
Portanto, deve-se considerar que, com a operacionalização da Lei Arouca, foi possível uma maior construção e publicização do conhecimento acumulado relativo às questões de saúde indígena, ainda que, até o momento, o conhecimento específico acerca dos agravos mentais de relevância epidemiológica em grupos étnicos (alcoolismo, drogadição e suicídio) seja incipiente, o que exige atenção de pesquisadores, gestores e profissionais da saúde (Santos et al., 2008; Erthal, 2001; Langdon, 2001; Levcovitz, 1998).

O reconhecimento da vulnerabilidade à saúde guarani com relação ao consumo de bebidas alcoólicas por parte dos trabalhadores da saúde da aldeia, tal como expressado pelos próprios indígenas, suscitou nessa equipe a necessidade de uma capacitação específica nesse campo de conhecimento, para subsidiar a construção de uma proposta de intervenção. Esse movimento somou-se às demandas por capacitações específicas, oriundas das equipes da ESF do município, o que possibilitou ao Conselho Municipal de Entorpecentes (Comen) (Brasil, 2008), instância de controle social para as políticas públicas sobre álcool e outras drogas, e à Coordenação de Saúde Mental de Angra dos Reis, promoverem um curso de sensibilização sobre o uso de álcool e outras drogas. Essa capacitação teve dois objetivos principais: qualificar os profissionais para o cuidado relacionado ao uso abusivo de álcool e outras drogas; e atender à especificidade cultural indígena, propiciando a construção de uma rede de atenção municipal para álcool e outras drogas sob a coordenação do Programa de Saúde Mental, com capacidade de responder em algum grau à especificidade dos usuários indígenas integrantes da população municipal.

Em continuidade à formação da rede de atenção, em 2001, realizou-se um diagnóstico situacional (Comen, 2001) sobre o uso de substâncias psicoativas e conhecimento sobre DST/Aids em jovens escolares das séries finais do ensino fundamental (oitavo e nono anos) e do ensino médio da rede pública de educação de Angra dos Reis, que apontou a prevalência de uso de álcool. O relatório final norteou a construção de uma proposta de ação no campo do uso abusivo de álcool e outras drogas para atender à demanda do município nessa área. No bojo dessas ações, o Comen ampliou a iniciativa no âmbito da capacitação de recursos humanos, promovendo o I Curso de Atualização em Relação ao Uso de Álcool e Outras Drogas, ministrado em 2002 pelo Núcleo de Estudos e Pesquisas em Atenção ao Uso Abusivo de Álcool e Outras Drogas (Nepad), da Universidade do Estado do Rio de Janeiro (Uerj), voltado para profissionais da rede pública, incluindo prioritariamente as equipes da ESF e EMSI, da saúde mental e da rede hospitalar, além de representantes das secretarias de Ação Social e Educação.

Essas ações foram potencializadas com a manutenção de atividades de supervisão e acompanhamento das ações assistenciais pelo Nepad, com o propósito de consolidar uma rede intersetorial de cuidados em saúde mental no campo de 
álcool e outras drogas. Entre as principais estratégias de superação do modelo tradicional de cuidado em Angra dos Reis - o modelo asilar -, profissionais da saúde mental do município foram contemplados, também em 2004, com o II Curso de Especialização para Profissionais dos Centros de Atenção Psicossocial de Álcool e Outras Drogas (Capsad) do estado do Rio de Janeiro, como parte do Programa Permanente de Capacitação de Recursos Humanos para a rede SUS (Brasil, 2004), procurando garantir a implicação dos profissionais em uma ética orientada pelos pressupostos da Reforma Psiquiátrica brasileira.

Estratégias como as anteriormente citadas são exemplos de experiências orientadas pelas necessárias articulações no campo de cuidados dirigidas às situações de uso abusivo de álcool e outras drogas. Na proposta do curso realizado em Angra dos Reis, os atores envolvidos reuniram-se em torno do alcance da integralidade que deve orientar o cuidado em saúde, conforme argumenta Cecílio (2006: 118), ao defender a qualificação da equipe multiprofissional como uma das formas de obtenção da confluência de saberes pertinentes para que esse grupo de profissionais seja capaz de responder ao conjunto das necessidades do usuário, caracterizado pelo autor como uma "cesta de necessidades". Ressalta-se, assim, a importância de convocar a sensibilidade de quem cuida, assim como o preparo para escutar, traduzir e atender o que da "cesta" se apresenta como demanda, procurando acompanhar o "modo de andar a vida" (Cecílio, 2006: 127) daquele que o procura.

Sobre o respeito ao sentido conferido pela cultura indígena às suas representações de saúde e doença e às específicas formas de andar a vida, cabe aqui a lembrança de que a Lei Arouca (Brasil,1999) determina a garantia de acesso dos indígenas ao SUS nos diversos contextos de cuidado, respeitando as especificidades socioculturais de cada povo. Essas recomendações são confluentes com as emanadas da III Conferência de Saúde Mental - "Cuidar sim, excluir não" (CNS, 2002) para inclusão dos povos indígenas na agenda da política de saúde mental e, mais recentemente, com as diretrizes do Ministério da Saúde para uma política de atenção integral à saúde mental das populações indígenas (Brasil, 2007).

Portanto, até 1999, a saúde indígena não era responsabilidade do MS, assim como, até 2001, não havia responsabilidade do Estado pela atenção integral à saúde mental; ou ainda, utilizando a metáfora de Cecílio (2006), não havia, até esse período, preocupação da saúde pública com o atendimento à "cesta de necessidades" das populações indígenas. Essas iniciativas, ainda que não direcionadas especificamente para os indígenas, induziram a proposição de um grupo de apoio dentro das aldeias de Parati, com a participação da EMSI, da Saúde Mental, do Comen e da Funai sob a supervisão de um psiquiatra do Programa de Saúde Mental de Angra dos Reis, conforme apresentado a seguir. 


\section{O estudo de caso guarani}

Algumas situações clínicas ocorridas na atenção aos Guarani no polobase de Angra dos Reis permitem exemplificar formas de atendimento à "cesta de necessidades" (Cecílio, 2006) dos usuários indígenas, o que responde à especificidade que se faz necessária nesse contexto de atenção diferenciada. Em Angra dos Reis, por exemplo, ainda que tenha havido preocupação por parte dos trabalhadores da saúde da aldeia acerca da problemática do uso de álcool, levantada por ocasião de oficinas de formação de multiplicadores para DST/Aids, essa questão não integrava a "cesta de necessidades" de saúde dos Guarani dessa localidade, à época. Assim, os profissionais que trabalhavam no polo-base buscaram desenvolver ações voltadas à prevenção, utilizando como estratégia metodológica a realização de conversas sobre o tema com lideranças e agentes indígenas de saúde. Utilizaram-se também os espaços de controle social na saúde indígena, como os conselhos locais, discutindose ali os problemas relacionados ao uso de bebidas alcoólicas e suas consequências, e a importância da disseminação dessas informações para todo o grupo.

Já nas aldeias de Parati, alguns indígenas sinalizaram, nos atendimentos médicos de rotina, o desejo de receber apoio para enfrentar problemas relacionados ao consumo de bebida alcoólica. Para acolher essa demanda, ativou-se a rede de cuidado à saúde mental, incluindo assim a atuação de profissionais da saúde mental do município de Angra dos Reis que, mediante os princípios organizativos do SUS de hierarquização e regionalização da atenção à saúde ${ }^{6}$ serviam de referência para os indígenas do município de Parati.

A abordagem terapêutica incluiu o atendimento regular na aldeia, o encaminhamento dos indígenas demandantes de apoio à psicóloga da Unidade de Saúde da Aldeia do Bracuí e ao médico psiquiatra do Programa de Saúde Mental de Angra dos Reis. A equipe multidisciplinar responsável considerou a indicação de acompanhamento medicamentoso sob supervisão, necessariamente associado a uma abordagem em grupo, com foco psicoterapêutico, exclusivamente dirigido aos indígenas e seus familiares, conduzido pelos profissionais da saúde mental e realizado no Caps de Angra dos Reis (Centro de Atividades Integradas de Saúde Mental - Cais), dispositivo que já se constituía em referência de saúde mental para a população indígena da aldeia de Angra dos Reis, desde 1993.

Baseando-se no compromisso da saúde mental com um de seus pressupostos fundamentais, qual seja o da lógica da atenção territorial e comunitária, e atendendo também ao princípio de acessibilidade aos serviços de saúde/saúde mental do SUS, considerou-se a importância da diversificação das ofertas de cuidado (Delgado, 1999), de forma a incluir as especificidades territoriais na atenção a esses indígenas demandantes do cuidado. Assim, fez-se necessário integrar a visão e os sentidos conferidos pelos Guarani aos problemas do álcool - e dos indígenas 
que dele se utilizavam - na construção das abordagens terapêuticas desenvolvidas pela equipe multidisciplinar, o que se tornou possível por meio da realização da abordagem em grupo dentro da própria aldeia, ou seja, no território daquela clientela e com a aceitação e participação de sua comunidade.

Assim, a psicóloga, o médico e alguns outros profissionais da EMSI deram início ao grupo de apoio a esses usuários na própria aldeia, contando com a participação das lideranças indígenas (políticas e religiosas), dos agentes indígenas de saúde das duas aldeias, das famílias dos envolvidos e de outros membros da comunidade, que foram se agregando espontaneamente ao grupo. Essa conformação correspondeu à visão cosmológica dos Guarani de que a bebida não é um problema apenas para quem bebe, mas compromete a relação familiar, social e com o seu próprio espírito e com as divindades (Ferreira, 2004).

As reuniões na aldeia eram realizadas semanalmente, em espaço aberto, e em todas as oportunidades de acolhimento e escuta ${ }^{7}$ eram identificadas e abordadas questões de interesse dos participantes indígenas, retomando experiências passadas e presentes em relação a temas como o uso de bebidas alcoólicas, as relações familiares e sociais, a morbimortalidade relacionada ao uso de álcool, os riscos de recaída e maneiras de enfrentamento dessas situações. Também se discutia a importância do fortalecimento das práticas tradicionais de cura e da rede de apoio social. Os participantes enriqueciam os encontros contando suas experiências sobre o uso de álcool, potencializando a disseminação das informações e a troca de experiências. À medida que o grupo se fortaleceu, as lideranças decidiram pela transferência das reuniões para o interior da casa de reza $(o p y)$, onde adicionalmente às atividades já realizadas, incorporou-se uma dimensão religiosa composta de rezas e dramatizações elaboradas pelos próprios indígenas sobre o uso de bebida alcoólica. Além desses espaços de acolhimento e cuidado, aconteciam rituais religiosos na casa de reza sem a presença dos profissionais da saúde, isto é, práticas de cura conduzidas pelos karaí, ${ }^{8}$ que eram valorizadas pela equipe de saúde por ocasião das reuniões, com o propósito de fortalecimento da tradição guarani e a consequente afirmação da identidade psicossocial do grupo (Ferreira, 2004-2005).

Em estudo realizado entre os Guarani no Rio Grande do Sul, Ferreira (2004-2005: 148) indica que, segundo eles próprios, o indígena "começou a beber quando começou a trabalhar para o branco, fora da aldeia". O uso de bebidas alcoólicas para os Guarani está associado ao abandono da prática de seus rituais, à inexistência de casas de reza (opy) e de karaí, assim como ao trabalho assalariado fora da aldeia, à proximidade das cidades e à escassez e inadequação de terras para a manutenção do modo tradicional de viver (Ferreira, 2004-2005). Esses múltiplos aspectos relacionados ao uso de bebidas alcoólicas entre os indígenas caracteriza esse problema como multifatorial, diferentemente da visão biomédica 
clássica do alcoolismo como dependência química, que se baseia no enfoque de determinação unifatorial.

Durante o período de trabalho foi possível observar a redução do uso de bebidas alcoólicas pelos participantes, bem como maior integração das famílias e do grupo de apoio. No percurso de exposição das terapêuticas desenvolvidas a partir da demanda de suporte gerada pelos Guarani, que se estendeu entre os anos 2001 e 2002, a Funasa cumpriu o importante papel institucional de garantir a regularidade no acesso dos indígenas participantes aos grupos de apoio, às reuniões e às consultas e atividades adicionais realizadas em unidades da rede de referência, mediante a disponibilização de um veículo para transporte dos integrantes do grupo entre as aldeias e para fora delas. Outro aspecto relevante foi a capacidade de acolhimento e escuta às demandas guarani por parte da equipe de saúde indígena e demais integrantes da rede de cuidados (Tesser, Neto G Campos, 2010). O acolhimento - condição de possibilidade de uma escuta cuidadosa e qualificada - viabilizou o desenvolvimento das ações de cuidado dentro da aldeia guarani, já que a postura da EMSI favoreceu o estabelecimento de uma relação de interesse, confiança e apoio entre usuários e profissionais (Camargo Jr. et al., 2006).

No período subsequente, houve interrupção desse trabalho, por razões de ordens diversas, tais como mudanças na política local e na gestão da saúde indígena e não indígena, fatos que retratam os desafios para condução e continuidade das políticas e ações de saúde diferenciadas para os povos indígenas em face da instabilidade da política local e das vontades particulares de cada dirigente setorial nesse nível de atenção (Chaves, Cardoso G Almeida, 2006). Além disso, evidenciouse, apesar da participação ativa dos indígenas de Angra dos Reis e Parati na conquista dos direitos à terra e ao acesso à saúde de forma geral, um frágil protagonismo indígena na luta pela continuidade dessa iniciativa de cuidado construída coletivamente, proveniente das demandas dos usuários.

Buscou-se articular outras estratégias para dar continuidade à proposta, mas isso não se tornou possível, acarretando prejuízos progressivos à condução do processo terapêutico, o que culminou na interrupção da rede de cuidado estabelecida. As dificuldades para dar prosseguimento ao trabalho permitem levantar algumas possibilidades que teriam contribuído, em maior ou menor grau, para a descontinuidade dessa iniciativa particular, mas que teriam reflexo sobre a atenção à saúde indígena como um todo. Entre elas podem ser evidenciadas: a rotatividade dos profissionais que compõem as EMSI, o que resulta em perda das competências desenvolvidas e dos vínculos estabelecidos com a comunidade; a incipiência da responsabilização pela saúde mental indígena e/ou insuficiência da organização das redes municipais de atenção à saúde mental de Angra dos Reis e Parati, à época, incapazes de elaborar estratégias para dar continuidade ao trabalho; e que os problemas relacionados ao uso de álcool, ou as estratégias adotadas para sua 
resolução, não foram identificados como aspectos relevantes a se considerar no enfrentamento do problema por parte da coletividade indígena, ainda que se tenha verificado motivação dos usuários e seus familiares durante os trabalhos.

\section{Considerações finais}

Considera-se a experiência vivenciada junto aos Guarani um exemplo prático de organização de uma rede de cuidados pautada nos preceitos da Reforma Psiquiátrica Brasileira e nas diretrizes que norteiam o SUS e as Políticas Públicas de Atenção à Saúde Indígena, de Saúde Mental e de Álcool e Outras Drogas. Essa experiência se coaduna com as vivenciadas em outros povos indígenas em distintas localidades do país, guardadas as devidas particularidades. Portanto, tal experiência tem o potencial de contribuir com subsídios para efetivar a implantação da Política Pública de Atenção Integral à Saúde Mental das Populações Indígenas (Ferreira, 2004) em contextos socioculturais específicos.

Apesar dos avanços alcançados durante o período de condução deste trabalho, ainda se está no início. O trabalho no campo da saúde mental, em particular o relacionado ao uso abusivo de álcool e outras drogas, é um processo recente e de construção lenta e progressiva, dependente de uma articulação multi-institucional, multiprofissional e intersetorial, de difícil operacionalização em qualquer esfera de atenção. As ações conduzidas no período aqui retratado foram viabilizadas pela formação de uma rede de apoio que se propunha à garantia da integralidade no cuidado e à escuta das demandas de uma "cesta de necessidades" de saúde, rede esta que se aproxima a um "tecido de possibilidades em permanente movimento, sensível às necessidades de mudanças e às dinâmicas apresentadas" (Cruz G Ferreira, 2007: 73). A discussão e a busca de alternativas para as problemáticas do uso de bebidas alcoólicas, utilizando recursos da própria cultura, colaboraram para um efeito de fortalecimento da tradição guarani e para a consequente afirmação da identidade psicossocial do grupo.

A descontinuidade do trabalho evidencia a dificuldade habitual de que haja, por um lado, a apropriação comunitária das ações de saúde, e por outro, a transformação de iniciativas piloto em políticas públicas permanentes. Considerase relevante para a construção e fortalecimento das políticas públicas no campo de álcool e outras drogas, em particular no caso dos povos indígenas, a ação integrada e hierarquizada dos diversos setores da saúde, a participação ativa da comunidade, a articulação dos diversos dispositivos de rede de cuidados intra e intersetorial, e o papel das instituições envolvidas em respeitar, apoiar e estimular as iniciativas tradicionais de enfrentamento dos problemas, o que contribui para o resgate da qualidade de vida indígena.* 
* Os autores dedicam a elaboração deste capítulo ao amigo Armando Barros (in memorian) que nos encorajou neste desafio, por acreditar que é possível a construção de uma práxis no campo das políticas públicas de saúde mental, álcool e outras drogas voltadas para os povos indígenas brasileiros.

1 Trabalho originalmente apresentado como comunicação oral no VII Congresso Brasileiro de Saúde Coletiva (Abrasco), em Brasília, em 2003, com o título "Alcoolismo nas áreas indígenas do estado do Rio de Janeiro: uma proposta terapêutica".

2 Ver também capítulo 4 deste livro.

3 Em 2010, foi criada a Secretaria Especial de Saúde Indígena (Sesai) na estrutura do Ministério da Saúde, para qual foi transferida a gestão do Subsistema de Atenção à Saúde Indígena, que se encontrava na Funasa desde 1999.

4 DSEI: espaço geográfico, populacional, étnico-cultural dinâmico e administrativo bem delimitado, estabelecido, que não guarda relação direta com os limites dos estados e municípios onde estão localizadas as terras indígenas; visa reordenar a rede de saúde e as práticas sanitárias, além de desenvolver atividades administrativo-gerenciais necessárias à prestação da atenção primária à saúde dos povos indígenas, com controle social (Funasa, 2002). Atualmente, existem 34 DSEI no país.

5 Polo-base é uma subdivisão do DSEI que engloba um conjunto de aldeias e suas EMSI, constituindo-se em instância regional de atenção à saúde indígena; funciona como primeira referência para os agentes indígenas de saúde que atuam nas aldeias. Eles podem estar localizados na área indígena ou num município de referência (Funasa, 2002).

6 Regionalização e hierarquização: princípios organizativos do SUS, segundo os quais os serviços devem ser organizados em níveis de complexidade tecnológica crescente, dispostos numa área geográfica delimitada e com a definição da população a ser atendida. Isso implica a capacidade dos serviços em oferecer à população todas as modalidades de assistência, bem como o acesso a todo tipo de tecnologia disponível, possibilitando um ótimo grau de resolubilidade (Brasil, 1990).

7 Acolhimento e escuta são conceitos recentes que se referem a uma postura das equipes de saúde que visa à melhoria das relações com os usuários, em que há uma escuta qualificada, o processamento da demanda do usuário e a busca de soluções compartilhadas, envolvendo a avaliação de riscos e vulnerabilidades biológicas, epidemiológicas e psicossociais. A partir da identificação dos problemas, vislumbra-se o acionamento de outros profissionais e instituições necessários à sua resolução (Tesser, Neto G Campos, 2010).

8 Os karaí são líderes religiosos que conseguem manter contato direto com nhanderu (deus), realizando curas dentro da tradição guarani. Habitualmente, essas cerimônias são realizadas na casa de reza, denominada opy (Ferreira, 2004). 


\section{Referências}

ALVES, D. S. Integralidade nas políticas de saúde mental. In: PINHEIRO, R. G MATOS, R. A. Os Sentidos da Integralidade na Atenção e no Cuidado à Saúde. Rio de Janeiro: Eduerj, IMS, Abrasco, 2006.

BARROS, E. P. Saúde indígena: a invisibilidade como forma de exclusão. In: GOLDENBERG, P.; MARSigliA, R. M. G. G GOMES, M. H. A. (Orgs.). O Clássico e o Novo: tendências, objetos e abordagens em ciências sociais e saúde. Rio de Janeiro: Editora Fiocruz, 2003.

BITTEnCOURT, L. M. Do Discurso Jurídico à Ordem Médica: os descaminhos do uso de drogas no Brasil, 1982. Dissertação de Mestrado, Rio de Janeiro: Departamento de Psicologia, Pontifícia Universidade Católica.

BRASIL. Ministério da Saúde. ABC do SUS: doutrinas e princípios. Brasília: Secretaria Nacional de Assistência à Saúde, Ministério da Saúde, 1990.

BRASIL. Ministério da Saúde. A Política do Ministério da Saúde para a Atenção Integral a Usuários de Álcool e Outras Drogas. Brasília: Coordenação Nacional de DST e Aids, Secretaria Executiva, Ministério da Saúde, 2003.

BRASIL. Ministério da Saúde. Legislação em Saúde Mental 1990-2004. Brasília: Secretaria Executiva, Secretaria de Atenção à Saúde, Ministério da Saúde, 5. ed., 2004.

BRASIL. Ministério da Segurança Institucional. Legislação e Políticas Públicas sobre Drogas. Brasília: Secretaria Nacional de Políticas sobre Drogas, Ministério de Segurança Institucional, 2008

BRASIL. Ministério da Saúde. Portaria 2.759, 25 out. 2007. Estabelece diretrizes gerais para a Política de Atenção Integral à Saúde Mental das Populações Indígenas e cria o Comitê Gestor. Diário Oficial, Brasília, 2007. Disponível em: <www.brasilsus.com.br>. Acesso em: 22 ago. 2010.

BRASIL. Senado Federal. Lei 9.836, 23 set. 1999. Acrescenta dispositivos à Lei 8.080, de 19 de setembro de 1990, que "dispõe sobre as condições para a promoção, proteção e recuperação da saúde, a organização e o funcionamento dos serviços correspondentes e dá outras providências", instituindo o Subsistema de Atenção à Saúde Índigena. Diário Oficial, Brasília, 1999. Disponível em: <www.senado.gov.br>. Acesso em: 7 ago. 2010.

CAMARGO JR., K. R. et al. Aspectos metodológicos da avaliação na atenção básica. In: PINHEIRO, R. G MATTOS, R. (Orgs.). Gestão em Redes: práticas de avaliação, formação e participação na saúde. Rio de Janeiro: Cepesc, 2006.

CARDoso, A. M. Prevalência de Doenças Crônico-degenerativas na População GuaraniMbyá do Estado do Rio de Janeiro, 2000. Dissertação de Mestrado, Rio de Janeiro: Escola Nacional de Saúde Pública Sergio Arouca, Fundação Oswaldo Cruz.

CARDOSO, A. M.; MATTOS, I. E. G KOIFMAN, R. J. Prevalência de fatores de risco para doenças cardiovasculares na população Guarani-Mbyá do Estado do Rio de Janeiro. Cadernos de Saúde Pública, 17:345-354, 2001. 
CARDOSO, A. M., MATTOS, I. E. G KOIFMAN, R. J. Prevalência de diabetes mellitus e da síndrome de resistência insulínica nos índios Guarani do estado do Rio de Janeiro. In: COIMBRA JR., C. E. A.; SANTOS, R. V. G ESCOBAR, A. L. (Orgs.). Epidemiologia e Saúde dos Povos Indígenas no Brasil. Rio de Janeiro: Editora Fiocruz, Abrasco, 2003. Disponível em: <www.books.scielo.org>. Acesso em: 9 abr. 2013.

CARLINI, E. A. et al. I Levantamento Domiciliar sobre o Uso de Drogas Psicotrópicas no Brasil: estudo envolvendo as 107 maiores cidades do país - 2001. São Paulo: Cebrid, Unifesp, 2002.

CECÍLIO, L. C. O. As necessidades de saúde como conceito estruturante na luta pela integralidade e equidade na atenção em saúde. In: PINHEIRO, R. G MATTOS, R. A. (Orgs.). Os Sentidos da Integralidade na Atenção e no Cuidado à Saúde. Rio de Janeiro: Eduerj, IMS, Abrasco, 2006.

CHAVES, M. B. G. A Política de Saúde Indígena no Município de Angra dos Reis: um estudo de caso, 2006. Dissertação de Mestrado, Rio de Janeiro: Escola Nacional de Saúde Pública Sergio Arouca, Fundação Oswaldo Cruz.

CHAVES, M. B. G.; CARDOSO, A. M. G ALMEIDA, C. Implementação da política de saúde indígena no polo-base Angra dos Reis, Rio de Janeiro, Brasil: entraves e perspectivas. Cadernos de Saúde Pública, 22(2):295-305, 2006.

CONSELHO MUNICIPAL DE ENTORPECENTES (COMEN). Relatório do estudo de qualidade de saúde entre estudantes do ensino público do município de Angra dos Reis. Relatório. Angra dos Reis, 2001. Relatório. (Mimeo.)

CONSELHO NACIONAL DE SAÚDE (CNS). Ministério da Saúde. Relatório final da III Conferência Nacional de Saúde Mental. Brasília, 2002. Disponível em: <www.conselho.saude.gov.br/biblioteca/Relatorios/saude_mental.pdf>. Acesso em: 6 mar. 2013.

CRUZ, M. S. G FERREIRA, S. M. B. O vínculo necessário entre a saúde mental e o Programa de Saúde da Família na construção da rede de atenção integral aos problemas relacionados ao uso de álcool e outras drogas. Cadernos IPUB, 24 (Saúde Mental na Atenção Básica): 67-80, 2007.

DELGADO, P. G. Atendimento psicossocial na metrópole: algumas questões iniciais. Cadernos Ipub, 14: 113-121,1999.

DELGADO, P. G. Drogas: o desafio da saúde pública. In: ACSELRAD, G. (Org.). Avessos do Prazer: drogas, Aids e direitos humanos. 2. ed. Rio de Janeiro: Editora Fiocruz, 2005.

ERTHAL, R. M. O. O suicídio tikuna no Alto Solimões: uma expressão de conflitos. Cadernos de Saúde Pública, 17: 299-311, 2001.

FERREIRA, L. O. O 'fazer antropológico' em ações voltadas para a redução do uso abusivo de bebidas alcoólicas entre os Mbyá-Guarani, no Rio Grande do Sul. In: LANGDON, E. J. G GARNELO, L. (Orgs.). Saúde dos Povos Indígenas: reflexões sobre antropologia participativa. Rio de Janeiro: Contra Capa, ABA, 2004.

FERREIRA, L. O. As demandas das políticas públicas e os povos indígenas. Humanas, 26-27:131-157, 2004/2005. 
FERREIRA, S. M. B. Sujeito, Trabalho, Álcool: contribuição ao estudo das relações entre a constituição do sujeito moderno, a organização do trabalho e o uso abusivo de bebidas alcoólicas, 2000. Tese de Doutorado, Rio de Janeiro: Instituto de Psiquiatria, Universidade Federal do Rio de Janeiro.

FERREIRA, S. M. B. Especialidade ou responsabilização? Algumas articulações entre clínica, política e formação no campo de cuidados a usuários de álcool e drogas. In: ENCONTRO NACIONAL DA ABRAPSO, XIV, 2007, Rio de Janeiro. Anais...Rio de Janeiro, 2007.

FUNDAÇÃO NACIONAL DE SAÚDE (FUNASA). Política Nacional de Atenção à Saúde dos Povos Indígenas. Brasília: Departamento de Saúde Indígena, Fundação Nacional de Saúde, Ministério da Saúde, 2002.

KUNITZ, S. J. G LEVY, J. E. Drinking Careers: a twenty-five-year study of three Navajo populations. New Haven, London: Yale University Press, 1994.

LANGDON, E. J. M. Saúde e povos indígenas: os desafios na virada do século. In: CONGRESO LATINOAMERICANO DE CIENCIAS SOCIALES Y MEDICINA, V, 1999, Isla Margarita. Anais... Isla Margarita, 1999.

LANGDON, E. J. M. O que beber, como beber e quando beber: o contexto sociocultural no alcoolismo entre as populações indígenas. In: SEMINÁRIO SOBRE ALCOOLISMO E DST/AIDS ENTRE OS POVOS INDÍGENAS, 2001, Brasília. Anais... Brasília: Coordenação Nacional de DST e Aids, Secretaria de Políticas de Saúde, Ministério da Saúde, 2001.

LEVCOVITZ, S. Kandire: o paraíso terreal - o suicídio entre os índios guarani do Brasil. Rio de Janeiro: Editora Te Corá, 1998.

LITAIFF, A. As Divinas Palavras: identidade étnica dos Guarani-Mbyá. Florianópolis: Editora da Universidade Federal de Santa Catarina, 1996.

MARINHO, D. P. Indicador de Vulnerabilidade à Aids através de um SIG: os GuaraniMbyá do estado do Rio de Janeiro, 2000. Dissertação de Mestrado, Rio de Janeiro: Instituto Militar de Engenharia.

NEVES, D. P. Alcoolismo: acusação ou diagnóstico? Cadernos de Saúde Pública, 20: 736, 2004.

ORGANIZAÇÃO MUNDIAL DA SAÚDE (OMS). Relatório sobre a saúde no mundo 2001: saúde mental - nova concepção, nova esperança. Lisboa, 2002. Disponível em: <www.who.int//whr>. Acesso em: 8 ago. 2010.

SANTOS, R. V. et al. Saúde dos povos indígenas e políticas públicas no Brasil. In: GIOVANELlA, L. et al. (Orgs.). Políticas e Sistema de Saúde no Brasil. Rio de Janeiro: Editora Fiocruz, 2008.

SOUZA, J. A.; OLIVEIRA, M. G KOHATSU, M. O uso de bebidas alcoólicas nas sociedades indígenas: algumas reflexões sobre os Kaingang da bacia do rio Tibagi, Paraná. In: COIMBRA JR., C. E. A; SANTOS, R. V. G ESCOBAR A. L. (Orgs.). Epidemiologia e Saúde dos Povos Indígenas no Brasil. Rio de Janeiro: Editora Fiocruz, Abrasco, 2003. 
SOUZA, M. L. P. G GARNELO, L. Quando, como e o que se bebe: o processo de alcoolização entre populações indígenas do Alto Rio Negro, Brasil. Cadernos de Saúde Pública, 23: 1.640-1.648, 2007.

TESSER, C. D.; NETO, P. P. G CAMPOS, G. W. S. Acolhimento e (des)medicalização social: um desafio para as equipes de saúde da família. In: TESSER, C. D. (Org.). Medicalização Social e Atenção à Saúde no SUS. São Paulo: Hucitec, 2010.

VELHO, G. Dimensão cultural e política do mundo das drogas. In: VELHO, G. (Org.). Projeto e Metamorfose: antropologia das sociedades complexas. Rio de Janeiro: Jorge Zahar, 1994. 


\section{Educação Escolar Indígena e a Bebida Alcoólica: reflexões sobre o contexto do Triângulo Tukano, Alto Rio Negro ${ }^{1}$}

Justino Sarmento Rezende ${ }^{2}$

A nossa vida humana é mesmo uma construção contínua. Hoje volto para os primeiros meses de vida quando eu vivia em um mundo muito especial, um mundo só meu, o ventre de minha mãe. Lá eu fui sendo tecido pedaço por pedaço, dia após dia. Eu estava bem protegido. Eu gostava!

Um dia tive que deixar este mundo que era só meu. Como dizem os meus avôs, ${ }^{3}$ deixei o 'banco da vida' ('útero materno' ou 'banco de leite', õpekõ kumurõ, em tuyuka) para os meus irmãos e irmãs que começaram a viver depois de mim. Eu nasci para o mundo maior. Espantei-me vendo um mundo muito maior do que o ventre da minha mãe. Diversas pessoas cuidaram de mim. Envolvido pelos seus cuidados, carinhos e afetos eu crescia e percebia que existiam muitas pessoas ao redor de mim que sorriam, elogiavam, admiravam e incentivavam. Fui crescendo e aprendendo a viver com os meus parentes, irmãos maiores e menores, tios e tias, avôs e avós, primos e primas. Com as crianças da minha idade brincávamos, chorávamos, brigávamos, corríamos, caíamos e levantávamos juntos! Tudo isso aconteceu num lugar chamado Onça-Igarapé, um lugar bonito!

Por diversos anos, a minha vida foi vivida nesse lugar, casa-família, convivendo com os meus parentes da aldeia, acompanhando a minha mãe na roça e o meu pai na pescaria e na caça, e também convivendo com os meus colegas. Com eles, transitávamos pelos areais para correr, cair e rolar, nos horários de brincadeiras. A gente se banhava nas águas frias e transparentes de Onça-Igarapé. Brincávamos juntos no pátio grande localizado no centro da aldeia. Nossos pais e parentes acompanhavam as nossas corridas, quedas, superações. Eles ficavam torcendo e achavam graça de nossas brincadeiras de crianças. Suávamos e ficávamos com os corpos cheios de terra. E, então, nossos pais nos diziam: "agora vão para o banho!". Corríamos juntos e disputávamos para ver quem chegaria primeiro ao porto e quem cairia primeiro na água. Nadávamos entre as correntezas de nossas belas cachoeiras. Voltávamos para casa e tomávamos o chibé ${ }^{4}$ ou manicuera (líquido de mandioca bem cozido) antes de deitar na rede que nos esperava o dia inteiro. E, por fim, dormíamos! 
Belas e exuberantes árvores envolvem o nosso povoado. Nelas os pássaros cantam suas melodias: tucanos, papagaios, bem-te-vis, japiins, rouxinóis. Corujas, sapos da noite, grilos, inhambus fazem ressoar suas melodias que nos ajudam a dormir e também nos assustam às vezes. Os vaga-lumes produzem suas pequenas luzes que se movimentam de um lugar para outro.

Pouco a pouco fui conhecendo outros lugares, outros parentes, primos e primas. O mundo não era só o nosso povoado. Existiam outras línguas, ${ }^{5}$ riquezas e práticas culturais.

Aos 9 anos conheci uma nova realidade: a escola! ${ }^{6}$ Por meio dela conheci novas culturas humanas indígenas e não indígenas. Comecei a aprender outros conhecimentos, tive contato com outras informações, outras técnicas, outros fatos, outras habilidades. Aprendi outros conteúdos, outras realidades, outras pessoas. Por isso, em minha mente, cada vez mais se fortalecia a ideia de tornar-me 'outro' e esse pensamento fazia esquecer-me de mim mesmo. Eu vivia me projetando para o futuro 'civilizado' (não índio), especialista, profissional, técnico, conhecedor das culturas ocidentais, com emprego (dinheiro), vivendo em cidades etc.

Mais tarde, essa projeção futurista foi reforçada pela minha saída da aldeia. Passei por algumas cidades e frequentei algumas escolas e universidades. ${ }^{7}$

Por alguns anos trabalhei no meio de meus parentes e conterrâneos indígenas do Alto Rio Negro. Conheci outras regiões e outros povos indígenas. São muitas riquezas que existem neste mundo! Muitas coisas boas continuam surgindo, outras desaparecendo e outras ressurgindo com novas formas.

Hoje eu sei dizer que existe um dinamismo muito forte no processo da construção histórica de nossas identidades indígenas. A vida indígena é dinâmica e complexa (rica, variada, desafiante, poderosa). As nossas culturas indígenas são os nossos espelhos: elas são aquilo que nós somos!

Nós, indígenas, estamos passando por rápidas mudanças. Hoje, criamos dentro de nós novas ideias a respeito de nossa vida, trabalho, costumes, religião, educação, escola, ritos, danças, dinheiro etc. Muitas mudanças mexem com as nossas vidas. Muitos conhecimentos e valores recebidos de nossos avôs e dos primeiros professores (missionários) passam por um processo de desconstrução e ressignificação. Nós compreendemos os valores, as práticas culturais e os conhecimentos do passado de outra maneira. Entendemos de um modo que faz sentido para a nossa vida de hoje. Desconstruir e ressignificar não quer dizer que devemos apagá-los da nossa história. "Tudo o que nos ensinaram no passado não presta e, por isso, vamos apagar!" - é isso que devemos evitar dizer e pensar.

Vejamos as nossas vidas hoje! Apesar de sentirmos fortes mudanças, temos também forte apego às nossas crenças anteriores, ideias e dogmas que os nossos avôs criaram. Eles, sim, se apresentam como estáticos, nem sempre acompanham o dinamismo do mundo, das histórias e das pessoas. Os nossos novos estilos de 
vida estão exigindo novas abordagens para entender a vida humana. E, nós, ao contrário, tentamos responder com instrumentos estáticos, acumulados em nossas mentes (crenças, ideias, dogmas, tradições) e livros.

As famílias, as comunidades, as lideranças, os educadores, os professores, os alunos, os pais, os gestores de escolas e os administradores procuram interagir em seus processos educativos (metodologias, pedagogias, conteúdos) com os bens das heranças culturais étnicas e os das heranças culturais ocidentais.

Desse modo, o foco principal desta reflexão é a bebida alcoólica na prática pedagógica de escolas indígenas. Utilizo aqui a expressão 'bebida alcoólica' para me referir tanto ao caxiri ${ }^{8}$ (bebida tradicional, com diversos graus de fermentação, com todas as suas denominações), como às demais bebidas alcoólicas industrializadas que vêm de fora. ${ }^{9}$ Atualmente a bebida merece uma atenção e reflexão sobre a sua 'compatibilidade' ou 'incompatibilidade' com as práticas educativas indígenas e, principalmente, com as práticas educativas escolares indígenas dos distritos do Triângulo Tukano ${ }^{10}$ (Pari-Cachoeira, Taracuá e Iauaretê), ${ }^{11}$ município de São Gabriel da Cachoeira, estado do Amazonas.

Mais especificamente, o objetivo desta reflexão é entender como uma das práticas culturais indígenas, que é o consumo de bebida (em tukano, sĩrĩsehe; em tuyuka, sinirẽ) pode ultrapassar os limites aceitáveis a ponto de dificultar o seguimento e a qualidade de programas educacionais.

Chamo este trabalho de reflexão, pois não é fruto de uma pesquisa de campo específica, mas se baseia na minha pertença-participação nas culturas indígenas do Triângulo Tukano e na observação, descrição e interpretação do modo de beber e das consequências que causam em nós (pais, mães, líderes, padres, professores, presidentes de associações indígenas etc.) que bebemos demais e nos nossos trabalhos.

\section{Memórias das narrativas de meu avô ${ }^{12}$}

Algumas memórias presentes em minha vida sobre os modos de beber caxiri são aquelas que meu avô me contava. Segundo ele, os nossos avôs bebiam em diversos momentos da vida: dias de trabalho, festa com os irmãos da comunidade, festa de acolhida ou despedida às visitas de parentes e primos, festa de ofertas (dabucuri) de frutas, animais (carne de caça), peixes, insetos, por exemplo. Dizia meu avô que se bebia também, e principalmente, nas cerimônias rituais de iniciação masculina e feminina e nas cerimônias de cantos-danças. Homens, mulheres, rapazes e moças ingeriam o caxiri.

Os adultos possuíam modos próprios de beber. Alguns ofereciam o caxiri para que a pessoa tomasse apenas o quanto conseguisse; outros obrigavam-na a beber tudo. Quem bebesse, por sua vez, deveria retribuir com a mesma quantidade, 
obrigando a pessoa seguinte a ingerir tudo o que tinha na cuia. Outras pessoas ofereciam duas e até três cuias em sequência. Todas essas práticas eram realizadas entre risos e gargalhadas. O modo de oferecer o caxiri acontecia (e ainda acontece) de forma circular: todos os que têm caxiri oferecem às pessoas (homens e mulheres) que estão sentadas em círculo. Dessa maneira, o número de cuias que a pessoa sentada recebia dependia de quantas famílias tinham prepararado o caxiri. Em algumas comunidades, a primeira rodada era de duas cuias para cada pessoa. Percebi também que, em algumas situações, já se oferecia o caxiri na hora de cumprimentar (na chegada da pessoa ao local da festa). Existem ainda muitas outras formas de oferecer a bebida.

Assim, cada família preparava o seu próprio caxiri. As mulheres continuamente buscavam aprimorar o seu grau de fermentação. O caxiri bem forte dava uma boa conceituação para a mulher ('mulher do caxiri forte'), e caxiri fraco diminuía tal conceituação. Os exímios bebedores do caxiri procuravam o que fosse mais forte. Para eles, uma festa boa era aquela em que as pessoas se embriagavam.

As festas cerimoniais duravam até três dias (entre acolhida/chegada, festa e final). As bebidas (diferentes tipos de caxiri) estavam bem presentes tanto durante o dia como durante a noite. Consumiam à vontade e até vomitavam. Muitas pessoas ficavam embriagadas. Dormiam, acordavam e tornavam a beber.

Os sábios, benzedores, cantores e dançarinos eram aqueles que 'aguentavam' mais. Os mestres de cantos e danças apresentavam-se bem ornamentados (plumas de japus, de garças, de araras, braceletes e chocalhos), por isso mantinham certo controle. No entanto, eram eles que tomavam a bebida alucinógena caapi ${ }^{13}$ (sabor amargo), consumida em pequenas quantidades, reservada para eles e aos outros já iniciados.

O caapi provocava visões (kapi bauare, em tuyuka, 'visão espiritual', 'inspiração', 'iluminação') sobre cantos, danças, benzimentos, discursos mitológicos e outros saberes naqueles que a consumiam. Para atingir tal nível, seguiam rituais de preparação: jejum, abstinência de certos alimentos (betire, em tuyuka), abluções com água (oko tsotire, em tuyuka) para purificação interior. Era necessário que um benzedor especializado (kapi doagtu, em tuyuka) e idôneo para realizar tal serviço preparasse o caapi para que produzisse o efeito esperado. Assim, essa bebida traz com ela muitas forças imateriais (espirituais) capazes de levar o consumidor para outro patamar (como, por exemplo, o nível das divindades de danças, dos entoadores de mitos etc.). O caapi possibilita também que as realidades divinas (luzes, iluminações e inspirações) desçam para pousar no indivíduo preparado (ele é como terreno bem fértil, onde é plantada a semente dos saberes de cantos e danças, benzimentos, mitos, cerimônias etc.) e ele, seguindo a disciplina estabelecida, faria com que esses saberes recebidos crescessem. 
Era o benzedor do caapi quem determinava, pela força dos benzimentos, os efeitos que aquela bebida produziria nos consumidores e naquele tipo de cantodança. Era ele que, também, conforme o andamento, poderia cortar o efeito do caapi. Assim meu avô dizia.

É muito importante observar que nas festas rituais todos os elementos envolvidos, ambientes e pessoas, eram benzidos. O espaço da casa de canto-dança era benzido; o ipadu, ${ }^{14}$ o breu, o cigarro (elementos mitológicos que dão origem à humanidade) e o caxiri eram benzidos. Todas essas forças imateriais geravam um contexto muito profundo para os participantes.

Após a participação nos rituais, os homens passavam um tempo determinado pelo benzedor de abstinência e jejum de certos alimentos. Os homens casados que participavam diretamente de rituais de cantos, danças e utilização de ornamentos sagrados, também seguiam um tempo de abstinência sexual.

Essas disciplinas favoreciam a continuidade das revelações divinas, espirituais e superiores sobre os cantos, danças, benzimentos, discursos mitológicos etc. recebidas durante os rituais. Além disso, serviam de prevenção de doenças que poderiam ser provocadas pelos espíritos de cantos-danças, ritmos, caapi, pinturas, cigarro, ipadu e que poderiam atingir fisicamente a pessoa (emagrecimento, dores de cabeça, tonturas, mordida de jararaca, ataque de onças etc.) caso não obedecesse às normas rituais.

Pelas memórias que tenho das narrativas de meu avô, as festas não aconteciam semanalmente; porém, sei que tinham relação estreita com os calendários solares e lunares ( verão, enchentes, época de piracemas, caças, coleta de frutas), o ciclo da vida (nascimento, rito de nominação, banho, alimentação, ritos de iniciação masculina e feminina, rito de alimentação) e calendários de relacionamentos interétnicos ${ }^{15}$ (visitas, acolhidas, despedidas, ofertas).

Como disse anteriormente, algumas festas duravam de dois a três dias. Depois das festas havia um tempo de descanso. Dormia-se durante um dia para recobrar as forças. Tal descanso estava previsto pelas tradições tuyuka. Por isso, a comida também estava prevista para acontecer nesse dia.

Durante as festas homens e mulheres adultos só bebiam e depois, no dia de 'dormir' (descanso), é que juntavam a comida para a alimentação comunitária.

\section{As forças positivas das festas de antigamente}

Estas são algumas observações minhas a respeito das forças positivas relacionadas às festas nas quais se consomem bebidas alcoólicas, que entendo que não esgotam o assunto. O leitor indígena e o não indígena que conhecem as culturas indígenas desta região podem e devem ampliar a lista dos benefícios da bebida 
alcoólica. Eles podem recuperar o sentido da bebida alcoólica desde a narração do mito da origem do ser humano até os dias de hoje.

Aponto algumas forças, mas dependendo do tempo de vida e da posição na hierarquia étnica (líder, benzedor, mestre de dança, mestre de discursos mitológicos, curador de doenças etc.), a lista de benefícios poderia ser maior ou menor. Não quero dar a entender que era apenas no momento de bebida e festas que se transmitiam os conhecimentos. Muitos deles eram (e são) transmitidos no dia a dia, fora das festas e sem bebidas alcoólicas: durante a madrugada, no caminho da roça, durante a pescaria/caça, durante as viagens, no fim do dia, comendo o ipadu etc.

Vejamos alguns conhecimentos que se transmitiam durante as festas dos tempos de meu avô:

1) Saberes étnicos: discursos de cumprimentos (acolhida e despedida), discursos mitológicos e discursos sobre os relacionamentos de parentesco.

2) Benzimentos: para o ciclo da vida (gravidez, nascimento, banho, alimentação, bebida, iniciação masculina e feminina); para apaziguamento das doenças do tempo (chuva, trovões...), das forças da floresta, das forças de animais (jararaca, onças...); benzimentos para doenças emergentes, como a gripe; preventivos de acidentes de trabalho, de convivência interétnica, curativos, das casas de cantodança; para a alma (usados nas cerimônias de nominação), de envio do espírito do falecido para a casa dos mortos.

3) Prática de cantos e danças relacionados ao tempo de fazer a roça (começo e fim), à iniciação masculina e feminina, ao apaziguamento das doenças do tempo.

4) Prática de diversos ritmos de danças mitológicas (popularmente conhecidas atualmente como 'danças dos velhos') e de inúmeros outros ritmos (dança do cariço, do japurutu, ${ }^{16}$ da cabeça do veado, do caracol, do osso de onça, do jabuti, da flautinha).

5) Técnicas para preparação do caxiri - utilização de diversas misturas para a fermentação.

6) Fortalecimento da unidade étnica: o irmão maior pedia que as suas cunhadas fizessem caxiri para que todos bebessem juntos, mantendo e fortalecendo a consciência étnica.

7) Funcionamento do espírito organizativo: convidar e acolher as pessoas, preparar a farinha e beiju, organizar as caçadas e pescaria para alimentação durante os dias de festas e pós-festa.

8) Prática de pinturas corporais com jenipapo e urucum, por exemplo; utilização de ornamentações. 


\section{As fraquezas das festas de antigamente}

A observação de nossas práticas culturais relacionadas à bebida mostra a modificação de nossos comportamentos nas áreas da saúde física, mental e emocional (espiritual). Embora nosso modo de ingerir bebida alcoólica pertença às nossas crenças culturais historicamente construídas, é importante observá-lo como algo que também pode trazer prejuízos à nossa convivência social e a nós mesmos.

Nas últimas décadas o álcool tornou-se um elemento insubstituível nos eventos programados pelos indígenas. Parece que nós indígenas não concebemos uma festa sem bebida alcoólica em grande quantidade. Ter ou fazer bastante caxiri é sinônimo de poder e domínio sobre aquelas pessoas que não podem prepará-lo em abundância. As relações de poder funcionam muito bem aqui. Talvez, por isso, todos queiram fazer o caxiri para não demonstrar que são mais fracos (ou mais pobres) que os outros. Diante dessa relação de poder, é comum ouvir: "aquela pessoa não tem nem roça para fazer beiju, fazer farinha, mas para fazer o caxiri tem!"

Hoje estou cada vez mais convencido de que nós indígenas somos desde a infância condicionados pelos nossos dogmas, crenças e teorias construídas pelos nossos avôs. Nós que ingerimos exageradamente bebida alcoólica ${ }^{17}$ sabemos que gera diversos prejuízos, como estes que enumero e que estavam já presentes nas festas de antigamente:

1) Embriaguez, perda de forças, quedas dentro e fora de casa e vômitos demonstram uma realidade bem antiga. Antigos viajantes - antropólogos não indígenas e missionários - já faziam suas anotações sobre essas situações (desumanas e degradáveis).

2) Desentendimento e briga entre algumas pessoas por relembrar os fatos passados, discussões, raivas, ressentimentos, vergonhas e fugas.

3) Descuido com as crianças - elas ficavam relegadas aos cuidados dos irmãos/ irmãs (também crianças), enquanto as mães ofereciam caxiri nas casas de cantodança (hoje chamadas de 'centros comunitários') e se embriagavam. Algumas crianças ficavam chorando em casa querendo se alimentar; e bebezinhos querendo mamar no peito da mãe.

4) Roubos (de objetos de uso pessoal, alimentação etc.) enquanto a maioria estava na casa de canto-dança.

5) 'Roubo' de mulheres e homens - alguns rapazes levavam as meninas para a escuridão para ter relações sexuais ou vice-versa, resultando em gravidez indesejada, abortos e desentendimentos entre os pais da menina e o rapaz que a 'roubou' ou com os pais dele. 
6) Surgimento de algumas doenças graves, tais como envenenamento por ervas e 'sopros' venenosos. ${ }^{18}$

7) Vergonha, medo e culpa por atos cometidos inconscientemente, como gritarias, grosserias e agressões, e culpa por não saber o que se fez durante o 'apagamento' (outros contam: "você fez isso, não se lembra?").

8) Indisposição para o trabalho e para a alimentação durante as festas e depois delas, por causa de ressacas, ânsias de vômitos e diarreias.

\section{As influências das práticas culturais não indígenas}

As culturas são construções históricas e se modificam ao longo do processo de formação de cada povo. As culturas dos indígenas que habitam o Triângulo Tukano passaram por diversas mudanças à medida que se ampliaram os contatos com outros povos, indígenas e não indígenas. Algumas práticas culturais mantêm semelhança com as do passado; outras surgiram com o contato com outras culturas não indígenas. É importante entender que os homens e as mulheres são seres históricos, possuidores de riquezas e fraquezas. Diferentes e novas práticas culturais foram trazidas e incorporadas ao longo dos anos. Vejamos:

1) Os ritos evangelizadores dos cristãos católicos entraram nas culturas indígenas e contribuíram para a modificação de algumas práticas culturais indígenas, que foram ressignificadas, desconstruídas e reconstruídas.

2) Hoje a maioria dos povos desta região é cristã. O contato com o cristianismo proporcionou a assimilação de outros dogmas, crenças, ideias, filosofias e teologias.

3) As práticas educativas escolares entraram nas culturas indígenas e contribuíram para a transmissão de conhecimentos ocidentais por meio das suas diversas disciplinas escolares - português, matemática, história, ciências, religião e geografia.

4) No início da ação evangelizadora praticada pelos salesianos e salesianas entre os povos do Triângulo Tukano, os não indígenas eram os agentes de evangelização e os indígenas éramos os destinatários. Com o passar dos anos e décadas, nós indígenas fomos assumindo diversas tarefas de evangelizadores. Hoje evangelizamos nossos parentes - catequistas (pregadores da palavra de Deus, dirigentes de cultos dominicais etc.), preparadores de sacramentos (batismo, primeira eucaristia, confissão, crisma e matrimônio), ministros extraordinários da eucaristia (homens e mulheres), padres e irmãs (freiras). Em algumas coisas levamos vantagem em relação aos missionários não indígenas: conhecemos a palavra de Deus através de seus ensinamentos, conhecemos as nossas culturas 
e as culturas não indígenas e falamos a nossa própria língua, além de entender a língua portuguesa. Temos muitos instrumentos para utilizar neste campo.

5) As práticas educativas escolares surgiram juntamente com as práticas evangelizadoras. Por isso seguiram a mesma dinâmica da evangelização. Inicialmente, os próprios missionários salesianos não indígenas eram professores, educadores, administradores, gestores e diretores. Os ex-alunos mais antigos até hoje se orgulham de terem estudado com os missionários e afirmam: "nós não estudamos com 'gente' (gente, aqui, refere-se ao indígena) como vocês estudantes de hoje". Essa afirmação quer dizer: 'nós estudamos com os donos do saber' (fontes dos saberes escolares). Ou ainda: 'o verdadeiro saber escolar é transmitido pelos não indígenas, pois a escola é uma instituição ocidental (entendida como não indígena)'.

6) Com o passar dos anos e décadas nós, indígenas, fomos aprendendo conhecimentos e técnicas ocidentais: conteúdos, didáticas, metodologias, pedagogias, filosofias etc. Fomos assumindo diversas tarefas no campo da educação escolar. Iniciamos como alunos, depois algumas pessoas passaram a ser professores para transmitir os saberes escolares aos nossos parentes. Hoje muitos deles estão assumindo funções de gestão escolar. Existem outros setores ocupados pelos indígenas: conselhos de educação escolar (estaduais e federais) e secretarias municipais de educação. Já percorremos um longo caminho e construímos nossas histórias no campo da educação escolar. Somos educadores de nossos parentes. Em alguns pontos levamos vantagens em relação aos não índios: conhecemos os conteúdos das disciplinas, conhecemos nossas culturas e as culturas não indígenas, muitos falam a própria língua ou pelo menos se fala a língua tukano, ${ }^{19}$ embora, poucos professores utilizem esse meio de comunicação na sala de aula, pois a língua preferida é o português. Temos muitos instrumentos das culturas indígenas para utilizar nesse campo, porém não aproveitamos. E temos que utilizá-los, pois não podemos mais colocar a culpa nos não indígenas pela falta de qualidade do ensino em nossas escolas. Se os filhos de nossos parentes indígenas (e os nossos) não conseguem aprender os conteúdos escolares, vamos ensinar-lhes nas línguas que eles possam compreender melhor; se eles quiserem que lhes ensinemos em língua nacional, vamos ensinar-lhes a língua portuguesa. Hoje, quanto mais línguas o professor tiver domínio será melhor, pois numa mesma sala existem alunos provindos de diferentes etnias. A filosofia intercultural de nossas escolas deve promover a utilização de instrumentos educativos interculturais. 


\section{Práticas educativas escolares e bebida alcoólica}

O espaço escolar é um espaço novo em nossas culturas indígenas, embora constatemos que muitos programas educacionais, ao serem realizados nesse contexto,

estabelecem relações estreitas com projetos familiares e comunitários (...), entrelaçam, confundem, dificultando a percepção de onde começa e termina uma prática escolar etc. (...) Algumas atividades se distinguem como atividades escolares, porém, a maioria é comunitário-escolar. Os projetos envolvem pessoas da comunidade e da escola. Há uma intensa negociação de espaços, tempos, agentes, líderes comunitários, pais, professores, anciãos, coordenador e alunos. Em outros momentos os professores e coordenador interferem com maior intensidade na vida comunitária do que lideranças comunitárias. (...) As práticas individuais (familiares) parecem perder um pouco de sua autonomia, no sentido de que em alguns momentos as comunidades acabam se envolvendo mais com o projeto escolar, deixando de lado os trabalhos pessoais. (Rezende, 2007: 189-190)

Nestes últimos anos, principalmente, quando nós indígenas assumimos os programas educacionais para recuperar e revitalizar os nossos saberes/ conhecimentos e práticas culturais, incluímos o caxiri nas nossas práticas educativas escolares. Como já acenei, o caxiri não se resume apenas a uma bebida, visto que se relaciona a um evento social com todas as suas riquezas e limitações. Mas o caxiri, nas últimas décadas, está provocando algumas preocupações e incômodos, que já devem ter sido percebidos por gestores, pais, alunos, professores, administradores, secretários e assessores escolares.

Essa preocupação não é nova. Em nossa região já foram realizadas diversas assembleias para estabelecer novos objetivos e estratégias para aumentar a qualidade da vida dos povos indígenas. Alguns pesquisadores já realizaram dissertações de mestrado e teses de doutorado, bem como publicaram artigos em revistas científicas abordando a questão do alcoolismo entre os indígenas de nossa região. ${ }^{20}$ Os resultados desses estudos não são de domínio público (a maioria do povo não tem acesso) e muito menos é do nosso conhecimento, mesmo que as pesquisas tenham sido realizadas no nosso meio.

Hoje, dentro da educação indígena e da educação escolar indígena na região do Triângulo Tukano, é importante organizar programas que ensinem a viver e lidar com a vida. A seguir apresento alguns dos problemas que estão bem presentes em nossa região e que devem ser enfrentados: os sofrimentos da vida (falta de dinheiro, de emprego, de perspectivas melhores para a vida); solidão (os velhinhos vivendo sozinhos sem amparo familiar, os filhos crescem, casam e deixam os pais 
sozinhos); confusão perante os desafios da vida (insegurança, medo); sentimentos de fracasso, ansiedade (dependência do passado, do êxito); medo do presente e do futuro (não se arriscar, não apostar), viver no futuro (não ter os pés no chão, viver sonhando); desespero (suicídios, enforcamentos, beber timbó); ${ }^{21}$ violências (tornarse agressivo, pensar e agir como se todos estivessem contra), criar brigas para se mostrar (ser visto, ser respeitado), o que acaba provocando autoexclusão social; doenças emocionais (tristeza, frustração, não ser amado, ciúmes); não saber lidar com a alegria, dinheiro, sucesso e conquistas (desvios de dinheiro, não prestar contas, entregar-se a vícios); dependências à bebida (vontade 'louca' de beber a todo momento, tremedeiras, visões, alucinações, ver fantasmas); cirroses, diarreias, emagrecimentos, 'barrigas d' água' etc.

Essas realidades novas desafiam as nossas culturas indígenas. Como lidar com isso? As sociedades não indígenas possuem instituições para atender essas realidades humanas (hospitais, psicólogos, psiquiatras, grupos de autoajuda, centros de tratamento, acompanhamentos profissionais para realizar atendimentos individuais e grupais). Nossas escolas não possuem esses recursos. Como, então, poderiam ser pensados esses desafios?

Os educadores, professores, alunos, pais, gestores, administradores, assessores pedagógicos indígenas (APIs) das escolas dos distritos citados anteriormente estão interagindo de maneira satisfatória com os bens das heranças culturais étnicas e os das heranças culturais ocidentais. Estão construindo seus projetos político-pedagógicos.

Temos, porém, algumas dificuldades que ultrapassam os nossos esforços e práticas. É nesse contexto que a questão da bebida alcoólica deve tornar-se um assunto a ser repensado com urgência, sobretudo as forças negativas que estão surgindo e atingindo alguns educadores, professores, alunos e pessoas em geral.

Nesta região poucos indígenas podem se considerar não bebedores. Para falar sobre esse tema me baseio em minha própria experiência com a bebida (sofrimento, vergonha, medo, insegurança, falta de credibilidade) e no conhecimento que tenho sobre as realidades dos povos indígenas da região. Alguns de nós não queremos estar nessas situações degradantes, mas não temos forças suficientes para sair delas sozinhos. Algo superior a nós e até mesmo pessoas corajosas devem surgir em nossas vidas para nos salvar, tirar-nos do fundo do poço, surgindo como salva-vidas.

Quando a bebida começa a tomar conta de nossa vida, de nossa vontade, de nossa liberdade, de nosso dinheiro e de nossas roças, é hora de desconfiar que algo muito sério está acontecendo conosco. Quem bebe demais sabe que quando estamos muito mal, após as festas, nos comprometemos a não beber mais, ou a beber menos, a não fazer mais caxiri e até mesmo não ir mais a festas. Basta que passem as nossas malditas ressacas, tristezas e vergonhas, lá estamos de novo 
bebendo! Ou para superar a vergonha continuamos bebendo mais. Assim, para muitos de nós vira uma rotina (beber-passar mal, recuperar-beber). Perdemos a moral diante da família, filhos, alunos, povo e das instituições. Outras pessoas continuam gozando de nós, explorando a nossa dependência, perdemos dinheiro e criamos dívidas. Os comerciantes não querem mais atender (vender) porque estamos devendo demais (ficamos com a fama de maus pagadores). Quem é casado leva xingamento da esposa porque nada traz para casa, a não ser o porre. Não compra as coisas para as necessidades dos filhos.

No início deste capítulo recuperei algumas memórias presentes na minha vida/história sobre o significado das bebidas (caxiri, caapi). A herança histórica que nos leva a afirmar: 'nós somos netos dos que beberam em diversos momentos da vida, beber faz parte de nossa cultura'. Falando assim, estamos decididos a continuar com esse hábito. A decisão menos adequada para nós, hoje, seria continuar do jeito que está ou cada vez pior, mesmo sabendo que está nos prejudicando. Muitos de nós temos medo de parar de beber por imaginarmos que os nossos amigos não vão mais gostar de nós, que não vamos poder mais ir a festas e que nos sentiríamos estranhos no mundo. Essas são as nossas racionalizações e justificativas para continuar bebendo.

Hoje em dia algumas ideias de nossos avôs (dogmas, crenças e teorias) permanecem e recebem as variações próprias que cada pessoa vai criando num contexto bem determinado (tempo, espaço, pessoas). Entretanto, podemos criar outras crenças, ideias sobre a nossa vida e nossos trabalhos.

\section{As forças positivas das festas atuais}

Praticamente todos os pontos enumerados quando apresentei as forças positivas relacionadas às festas de antigamente acontecem nos dias atuais nas escolas indígenas. Destaco apenas que um número menor de danças é ensinado agora, uma vez que algumas delas ninguém mais sabe como dançar. No entanto, também é preciso dizer que há um conjunto novo de situações motivadoras de festas nas quais se consomem bebidas e que se associam ao conjunto de outros ensinamentos, tais como:

1) Festas ligadas à cultura cristã (batizados, primeira eucaristia, crisma, casamento, aniversário e festa de padroeiros) - aprende-se a convidar e acolher os convidados, a participar dos banquetes como convidados, a levar presentes, a participar dos bailes, a contribuir com alimentos, com caxiri e outras bebidas.

2) Festas de encerramento de cursos - costuma-se realizar dabucuri e se aprende a agradecer o trabalho dos professores/formadores. 
3) Festas de tomada de posse de associações indígenas - aprende-se a agradecer às lideranças que saem e a parabenizar os novos líderes das comunidades e seus animadores.

\section{As fraquezas das festas atuais}

O problema com o consumo de bebida alcoólica nas últimas décadas atingiu muitas pessoas, inclusive aquelas envolvidas com o processo de educação escolar. Em Iauaretê, por exemplo, em diversas assembleias, reuniões das comunidades e de pais, discutiu-se sobre a diminuição da quantidade de caxiri e dos dias de festas, com o objetivo de evitar que os alunos fossem prejudicados. Porém, poucas vezes tais discussões se tornaram ações efetivas e positivas. Juntamente com o pouco compromisso com as propostas assumidas para lidar com as dificuldades relacionadas ao uso de bebidas alcoólicas, surge um conjunto de novos problemas que de certa forma se somam àqueles enumerados anteriormente, quando apresentei as dificuldades/fraquezas das festas de antigamente:

1) Aumento do caxiri - muitas famílias e comunidades fazem caxiri em todos os fins de semana. Está havendo uma obsessão pela bebida: "um bom final de semana é aquele que tem caxiri".

2) Dependência dos compulsivos pela bebida - com a aproximação do fim de semana aumenta a ansiedade (falta de concentração, alguns até abandonam o trabalho ou as aulas). Muitos passam a procurar quem tenha a bebida para vender.

3) Existência de pessoas que vivem do comércio do caxiri - o interesse é vender e lucrar. Não pensam nos prejuízos das outras pessoas ou da comunidade.

4) Utilização de fermento de pão para acelerar o processo de fermentação do caxiri.

5) Adição de pequenas quantidades de timbó ao caxiri, segundo alguns comentam, para que fique mais forte e, assim, venda mais e dê mais lucro. Serve-se, também, em alguns lugares, caxiri misturado com cachaça (ou álcool), o que interessa mesmo é atingir o mais rápido possível o estado de embriaguez, quanto mais forte a bebida mais ela será procurada pelos consumidores.

6) Aumento do número de consumidores (bebedores) adolescentes e jovens, meninos e meninas - geralmente não são eles que preparam o caxiri, mas os adultos. Os adolescentes e jovens bebem em grupo. Passam nas casas de amigos para beber. Meninos e meninas bebem juntos; a maioria deles quando chega aos centros comunitários já está embriagada.

7) Aumento do consumo de açúcar ${ }^{22}$ entre a população - mas não é para tomar com café, leite ou suco, mas sim para fazer o caxiri. 
8) Consumo do caxiri mesmo fora das festas - antigamente quando acabavam os dias das festas, o caxiri que sobrava era jogado fora. Hoje, as pessoas saem de casa em casa juntando o que sobrou, vão coando para aproveitar até as últimas gotas. Nada se perde.

9) Aumento de problemas envolvendo jovens e adultos devido ao consumo exagerado de bebidas alcoólicas - alguns, durante a embriaguez, perdem as forças, ficam caídos e vomitam. Outros criam brigas nos centros comunitários. As brigam muitas vezes são entre grupos de diferentes vilas. Seus membros, às vezes, andam encapuzados e carregam facas nas cinturas, provocando ferimentos e esfaqueamentos. Durante o consumo de bebidas alcoólicas ocorrem mortes por assassinatos, afogamentos e enforcamentos.

10) Brigas durante as festas - é difícil ver uma festa que acabe bem. Geralmente, as lideranças encerram as festas antes do horário previsto em função das brigas.

11) Mortes durante as viagens por excesso do consumo de bebidas.

\section{Até que ponto a bebida alcoólica é compatível ou incompatível com as práticas educativas escolares na região do Triângulo Tukano?}

Em Iauaretê eu convivi com pessoas de diversas comunidades, de diversas etnias e de diferentes idades. Quem mora neste lugar já deve ter notado que o nosso modo de beber e a frequência com a qual fazemos festas desestabilizam o funcionamento normal das comunidades e escolas: ${ }^{23}$ agressões físicas, arrombamentos de comércios, brigas, esfaqueamentos, enforcamentos, roubos de motores de popas, rabetas e voadeiras estão entre os problemas vivenciados. Tudo isso tira a tranquilidade do povo, gera desconfianças, medos, inseguranças e revoltas.

Na escola São Miguel, ${ }^{24}$ por exemplo, era comum, nas segundas-feiras, muitos alunos chegarem atrasados à escola e serem dispensados das aulas. Os alunos saíam satisfeitos porque era um bom motivo para continuar bebendo. $\mathrm{Da}$ mesma forma ocorria com alguns professores (homens). Assim, para esses estudantes e docentes a semana letiva iniciava-se na terça-feira e acabava na quinta-feira. $\mathrm{Na}$ sexta-feira alguns já escapavam para beber no intervalo das aulas, pois já existiam pessoas vendendo o caxiri. A bebida atinge também outros eventos: reuniões comunitárias, programações religiosas e esportivas (diversas vezes eu vi uma equipe inteira não comparecer ao jogo marcado por estar consumindo bebidas alcoólicas em outros lugares, ou porque seus membros já estavam embriagados). 
Aquelas pessoas que ingeriram bebida alcoólica, principalmente aqueles que beberam de modo excessivo, já sentiram na vida alguns destes efeitos:

1) Em nível físico - ressaca, indisposição para se alimentar, dor de cabeça, tontura, tremedeira, dor de estômago, diarreia, ânsia de vômito, insônia ou sonolência, cansaço, fraqueza, olho avermelhado, marca de briga e de queda etc.

2) Em nível mental - diminuição da vontade de trabalhar, de estudar e da motivação para fazer coisas boas; desatenção e desconcentração que impedem o exercício de ensinar e de aprender; inquietação, ansiedade, não lembrar as coisas, não organizar as ideias.

3) Em nível emocional (espiritual) - vergonha, medo, raiva, culpa, autopiedade, autocondenação, ter que aguentar gozação dos outros, irritabilidade, hipersensibilidade, mentiras, acusações, arrependimentos, promessas, apagamentos (não se lembrar do que fez e do que falou).

A partir dessas características apresentadas por algumas pessoas de nossas comunidades, poderíamos nos perguntar: será que a nossa bebida, nosso caxiri não está nos deixando doentes e dependentes?

Os especialistas em alcoolismo afirmam que esta é uma doença progressiva, incurável e fatal. O alcoolismo é uma doença física, mental e emocional (espiritual). Entre os indígenas do Triângulo Tukano, é fácil encontrar pessoas em estágios avançados do problema, dependentes do álcool para viver e trabalhar. Muitos já morreram e a causa das mortes foi o consumo da bebida alcoólica: cirrose hepática, assassinatos, enforcamentos, envenenamentos e afogamentos. Como aconteceu com muitas pessoas, pode acontecer comigo e com outros, se continuarmos bebendo.

No espaço escolar há a diminuição da qualidade do ensino-aprendizagem. Alguns professores em certos dias não estão em condições (físicas, mentais e emocionais) para ensinar. Muitos alunos não conseguem assimilar os conteúdos e o rendimento deles é baixo.

A bebida atrapalha o desempenho dos alunos e professores em salas de aula. Os professores não dedicam tempo para preparar aulas, nem os alunos para fazer as tarefas. O poder de concentração do estudante diminui à medida que se inicia nas bebedeiras. A sonolência impede a atenção e a aprendizagem. A ansiedade tira a concentração dos temas da aula, pois o leva a estar presente mentalmente em outros espaços. É bem certo que no fim de semana os alunos (adolescentes, jovens e adultos) dificilmente dedicarão tempo para estudar e fazer tarefas. E, o que dizer do professor? Será que ele dedica o fim de semana para preparar suas aulas, corrigir tarefas dos alunos, concentrar-se para transmitir bem os conhecimentos? 
Nas semanas em que não há festas é visível o entusiasmo dos professores e alunos. A alegria está estampada em seus rostos, os sorrisos são diferentes. O interesse pelos temas das aulas aumenta. Também os professores ficam animados, sem aquela ressaca emocional (vergonha, desconfiança). Sabem que estão fazendo o seu melhor e sabem que estão certos do que estão fazendo. Os gestores e administradores também ficam tranquilos, sem a necessidade de ficar com medo de alguns alunos e professores que não estão seguindo o projeto de educação da instituição. Assim, é fácil perceber a capacidade indígena para educação escolar e a qualidade que isso gera.

Basta aparecer a bebida para estragar esse cenário bonito. Já aconteceram casos, em algumas escolas, de levarem bebidas para sala de aula e haver brigas. E, o que dizer dos 'bafos' de caxiri que se espalham e atrapalham os alunos que gostariam de ter um ambiente tranquilo para aprender? O que dizer dos roubos de garrafas de álcool das escolas? Quem pode ser? Alunos e professores irritados circulam pelo espaço escolar! A agressividade e a raiva são utilizadas como defesas diante do gestor ou coordenador. E, muitas vezes, nós indígenas temos medo uns dos outros. Chamar a atenção de um professor ou de um aluno é correr o risco de ser agredido! Nessas situações aparecem as consequências de nosso consumo exagerado de bebidas.

Por sua vez, há esforços de muitas pessoas para cumprir bem seus compromissos, tais como liderar reuniões, lecionar, estudar etc. Elas se incluem no grupo que sabe beber. Quem tem predisposição para se tornar alcoólatra no início de sua carreira alcoólica é sempre mais forte, bebe mais, aguenta mais. Até leva os outros para casa e volta a beber. Ele se considera forte, mas poderá tornar-se um alcoólatra. Até certo estágio de sua bebedeira, a tolerância de seu físico é grande, mas com a progressão do alcoolismo, a resistência diminui, ele se torna fraco e vai sendo destruído progressivamente. Por isso se afirma que o alcoolismo é progressivo, incurável e fatal. A Organização Mundial da Saúde classificou-o como uma doença que causa transtornos mentais e comportamentais. Embora não tenha cura, pode ser estacionada, para isso não se deve ingerir nenhum tipo de álcool, em qualquer que seja a quantidade. É importante dizer que, quando alguém para de beber, caso tenha recaídas, começa a beber de onde parou (não vai começar do zero).

Entre nós, indígenas do Triângulo Tukano, o consumo de caxiri está se tornando cada vez mais intenso. Em alguns distritos, como disse anteriormente, o caxiri tornou-se um produto muito lucrativo. Quem faz e comercializa, ao entrar nessa dinâmica, não se preocupa tanto com os prejuízos que está causando para os seus filhos e parentes.

Por ser importante nas culturas indígenas de nossa região, o caxiri tornouse um elemento que move parte da educação indígena e da educação escolar indígena. Afirmamos que é durante o consumo da bebida que se ensinam algumas 
práticas culturais indígenas. É inegável, no entanto, que os discursos a favor do nosso caxiri e de outras bebidas alcoólicas são mecanismos de defesa para continuarmos bebendo. Muitas vezes só paramos para refletir com mais profundidade sobre as consequências negativas diante das mortes: afogamento, suicídio (enforcamento, tomar timbó), assassinatos, brigas. Entretanto, penso que no fundo de nossa alma perguntamos e buscamos alguma saída melhor.

Por que queremos mudar o que é, ou causar transformação? Por quê? Porque o que somos não nos satisfaz. Isso cria conflito, distúrbios, e não gostando dessa situação, queremos algo melhor, mais nobre, mais idealista. Então, desejamos transformação porque há dor, desconforto, conflito. (Krishnamurti, 2007: 67-68)

Se olharmos bem para as nossas histórias indígenas, elas nos mostrarão que nas épocas de nossos antepassados não existiam escolas. Hoje temos essas instituições com todas as suas exigências: disciplina, presença, pontualidade, participação, calendário e avaliação. Estamos vivendo e construindo outras histórias. As histórias são do jeito que nós somos e do jeito que as fazemos.

Já construímos muitas realidades bonitas desde os nossos avôs até os dias de hoje. As escolas estão aí como nós as queremos e fazemos. Queremos continuar indígenas, mas também queremos aprender as riquezas culturais de outros povos não indígenas. Quais das nossas práticas culturais devem ajudar a construir nossas escolas? Nossas escolas seriam escolas de transformação (nas mitologias de nossa região: casas de transformação). ${ }^{25}$ Como vamos lidar com a bebida alcoólica e suas consequências sobre as pessoas com as quais trabalhamos? Falar dessa realidade é preocupar-se com a vida das pessoas em geral: pais, mães, lideranças (políticas, religiosas, civis), filhos, netos, jovens e adultos. A bebida alcoólica gera prejuízos financeiros. Poderíamos nos perguntar: quanto dinheiro eu gastei comprando caxiri e outras bebidas desde que comecei a consumir álcool? Quantas vezes fui roubado porque estava 'bem passado em bebida'? Que materiais de necessidade pessoal, familiar e comunitária deixei de comprar? Que prejuízos dei para minha comunidade e minha associação por estar bebendo? É bem verdade que não podemos lamentar pelo que já passou, mas não é proibido imaginar que, se não fosse a bebida a tirar o nosso dinheiro, muitas pessoas teriam adquirido muitas coisas para suas casas, famílias e comunidades!

Na nossa região do Triângulo Tukano muitas pessoas ganham dinheiro: funcionários públicos (professores, enfermeiros, militares), aposentados, beneficiados pelos programas de governo, pescadores, vendedores de cipó, serradores. É comum ver que quem não é controlado pela bebida constrói casas melhores, compra móveis para casa, compra motor de popa, voadeira, roupas e monta comércio. 
Observando atentamente, a bebida alcoólica atrapalha a vida dos povos indígenas de nossa região. Destrói, divide, gera brigas (inclusive de gangues, assassinato, violência) e abandono das comunidades.

Essas realidades repercutem nos espaços escolares. Devemos, como indígenas, refletir como comunidades comprometidas com as nossas escolas, com os nossos alunos, com nossos professores e com a qualidade do processo ensinoaprendizagem. Enquanto isso ficar reduzido apenas ao esforço de gestores de escolas e lideranças, continuará sendo algo sem a força necessária para modificar o estilo de vida. Quando assumirmos decisões mais práticas, certamente nossas vidas, comunidades e escolas vão respirar um novo ar. Em muitas assembleias e escolas, fala-se com frequência que a escola é da comunidade, que a escola é comunitária, que a escola age conforme o que a comunidade decide. Então o que podemos fazer diante dessa realidade? Fica evidente que devemos fazer escolhas e tomar decisões. No caso específico das escolas indígenas do Alto Rio Negro, o consumo excessivo de bebida alcoólica deverá ser enfrentado por meio de políticas públicas (campanhas, conscientização, normas etc.).

\section{Fechando a conversa}

O tema da bebida e suas consequências há tempo provoca frequentes discussões em diferentes tipos de reuniões. Minha previsão é de que tal realidade será apenas modificada quando as comunidades e escolas decidirem dar um novo direcionamento para suas vidas e seus trabalhos.

Nós indígenas somos inteligentes e aprendemos e ensinamos com facilidade o que aprendemos. A prova dessa constatação está aí: professores, gestores, militares, enfermeiros, profissionais, lideranças, comerciantes, ministros eclesiais (padres, ministros extraordinários, catequistas), desportistas, músicos indígenas etc. Temos muitos professores formados em cursos superiores e outros tantos estudando nas cidades. Atualmente são muitos os cargos e espaços políticos que ocupamos.

Somos capazes de gerar comunidades criativas. Somos capazes de assumir com alegria e entusiasmo em nossos espaços escolares a tarefa de ensinar/educar dentro de um processo ensino-aprendizagem de muita qualidade. As nossas crianças, adolescentes, jovens e adultos estudantes merecem receber um ensino de qualidade oferecido por bons profissionais.

Quando estamos sóbrios (física, mental e emocionalmente), fazemos muitas coisas maravilhosas. O que estraga, para alguns profissionais, é a bebida. Aí cai o nosso entusiasmo, nossa alegria, e nossa capacidade de ensinar e de motivar. 
A decisão de viver melhor a vida, antes de tudo, é uma decisão pessoal. A comunidade (educativa) pode nos ajudar, mas as iniciativas só irão funcionar se a pessoa decidir e aceitar a ajuda.

As nossas escolas são estruturas materiais, mas nós, professores(as), funcionários(as), gestores(as), alunos(as), somos pessoas humanas, que precisamos cuidar de nós. Merecemos viver melhor!

Notas

1 Este capítulo é uma versão revisada de: Rezende, J. S. Educação escolar indígena e a bebida alcoólica. Ethos G Episteme, V(X): 107-124, 2009. Texto republicado com autorização do autor e do editor da revista.

2 O autor é da etnia Tuyuka, do distrito de Pari-Cachoeira, município de São Gabriel da Cachoeira (AM), e sacerdote da Sociedade de São Francisco de Sales (salesianos) desde 1994.

3 Utilizo o termo 'avôs' seguindo a lógica indígena. Em tukano se diz: marĩnektustumuãa ('nossos avôs'), para se referir ao que em língua portuguesa se costuma chamar de antepassados. Não utilizo a forma usual 'avós', por um lado, para manter a expressão usada localmente e, por outro, para demarcar que me refiro aos antepassados do sexo masculino, uma vez que nesse contexto o pertencimento étnico segue a linha patrilinear.

4 Mistura de água e farinha de mandioca, muito apreciada na região (Nota do Organizador N.O.).

5 No Alto Rio Negro existem mais de vinte povos indígenas, que são identificados como falantes atuais ou em tempos anteriores de suas próprias línguas. Assim, falar que existiam 'outras línguas' também significa, neste contexto, dizer que existiam outros povos indígenas (N.O.).

6 As escolas em moldes ocidentais, no Alto Rio Negro, foram introduzidas pelos missionários salesianos, fazendo parte de suas estratégias de catequização, a partir da segunda década do século passado (N.O.).

7 Fui para Manaus porque entrei no Centro Vocacional Salesiano (CVS) em 1980. Já estou peregrinando há muitos anos fora de minha aldeia: CVS (Manaus, 1980-1982), noviciado (São Carlos/SP, 1983), pós-noviciado (Manaus, 1984-1986), tirocínio (espécie de estágio religioso) (Porto Velho, 1987; Pari-Cachoeira, 1988), graduação em teologia (São Paulo, 1989; Manaus, 1990-1992; Guatemala, 1993). A partir do diaconato: Iauaretê (1994-1996), São Paulo (19971999), Manaus (2000-2003), Iauaretê (2004), Campo Grande/MS (2005-2006), Iauaretê (2007-2008), Curitiba (2009) e Marauiá (2010).

8 A origem do caxiri está mesmo na origem humana, por isso tem um sentido mitológico e social. Esta bebida deve ser compreendida com base nas canoas e casas de transformações (casas de origens, de surgimento). Por isso, nos rituais de cantos-danças na casa de canto-dança (basawi), que os não indígenas chamam de maloca, o caxiri passa pelo benzimento, como um dos elementos que facilitará a boa interação dos participantes da festa. 
10 Os habitantes desses três distritos falam línguas que pertencem ao tronco linguístico tukano, daí a denominação 'Triângulo Tukano' (N.O.).

11 Pari-Cachoeira, Taracuá e Iauaretê são localidades indígenas que foram sede das missões dos salesianos. Nesses locais construíram-se capelas e colégios que até o final da década de 80 do século passado funcionavam em regime de internato. Atualmente reside nessas comunidades uma grande e atípica quantidade de indígenas que para lá migram, sobretudo para dar continuidade aos estudos dos filhos (N.O.).

12 Meu avô tuyuka chamava-se Higino Barreto Rezende (nome de benzimento, buá). Ele era baya (mestre de cantos e danças), kumu (pensador, entoador de mito e orador de discursos cerimoniais) e basegt (benzedor). Faleceu no ano de 1983.

13 Substância alucinógena extraída de uma espécie de trepadeira amazônica chamada Banisteripsis caapi (N.O.).

14 Preparado à base de folha de coca pilada (N.O.).

15 Interétnico é utilizado pelo autor no sentido de 'entre diferentes grupos étnicos indígenas' e não no sentido entre indígenas e não indígenas (N.O.).

16 Cariço: tipo de flauta de Pan; japurutu: tipo de flauta longa (N.O.).

17 A preocupação não ocorre com as pessoas que sabem se controlar.

18 O autor se refere a formas xamânicas de agressão (N.O.).

19 A diversidade linguística da região do Triângulo Tukano foi severamente abalada pela ação missionária, visto que nas primeiras escolas salesianas o tukano foi usado como língua de interação entre esses religiosos e os indígenas, em detrimento das demais línguas. Atualmente, diversos grupos da região não falam mais suas línguas ancestrais, mas têm o tukano como língua franca (N.O.).

२0 Um desses trabalhos foi a tese de doutorado de Souza (2009), organizador deste livro.

21 Tipo de veneno extraído de raízes (N.O.).

22 Durante o processo de preparação de caxiri, atualmente se mistura açúcar para incrementar e acelerar a fermentação (N.O.).

23 Essas minhas observações foram feitas nos anos de 2007-2008.

24 Escola estadual, que oferece inclusive ensino médio (N.O.).

25 O autor ao utilizar a expressão 'escolas de transformação' está fazendo uma comparação da escola com as 'casas de transformação'. Estas últimas, nas diversas versões dos mitos de origem dos povos da região, seriam como espécies de entrepostos nos quais os ancestrais míticos adquiriam cantos, danças, benzimentos, adornos etc. Cada apropriação desses diferentes bens 
simbólicos, que se dava nesses locais, era como um passo a mais na trajetória que ligaria a préhumanidade primordial a humanidade plena, que de fato se encontraria em eterno devir (N.O.).

\section{Referências}

KRISHNAMURTI, J. O que Você Está Fazendo com a sua Vida? Passagens selecionadas sobre as grandes questões que nos afligem. Rio de Janeiro: Nova Era, 2007.

REZENDE, J. S. Escola Indígena Municipal фtãpinopona-Tuyuka e a Construção da Identidade Tuyuka, 2007. Dissertação de Mestrado, Campo Grande: Universidade Católica Dom Bosco.

SOUZA, M. L. P. Juventude, Uso de Álcool e Violência em um Contexto Indígena em Transformação, 2009. Tese de Doutorado, Rio de Janeiro: Instituto Fernandes Figueira, Fundação Oswaldo Cruz. 
Formato: $21 \times 26 \mathrm{~cm}$

Tipologia: Egyptian 505 BT/Baker Signet BT

Papel: Offset $90 \mathrm{~g} / \mathrm{m}^{2}$ (miolo)

Cartão Supremo $250 \mathrm{~g} / \mathrm{m}^{2}$ (capa)

CTP, Impressão e acabamento: Imos Gráfica e Editora Ltda.

Rio de Janeiro, junho de 2013

Não encontrando nossos títulos em livrarias, contactar:

EDITORA FIOCRUZ

Av. Brasil, 4036, $1^{\circ}$ andar, sala 112 - Manguinhos

21040-361 - Rio de Janeiro - RJ

Tel.: (21) 3882-9039 e 3882-9007

Telefax: (21) 3882-9006

editora@fiocruz.br

www.fiocruz.br/editora 